OAK RIDGE

ORNL/TM-2012/488

NATIONAL LABORATORY

MANAGED BY UT-BATTELLE

FOR THE DEPARTMENT OF ENERGY

\title{
Advancing Residential Retrofits in Atlanta
}

\author{
March 2012
}

Roderick K. Jackson

Eyu-Jin Kim

Sydney Roberts

Robert Stephenson

UT-BATTELLE 


\section{DOCUMENT AVAILABILITY}

Reports produced after January 1, 1996, are generally available free via the U.S. Department of Energy (DOE) Information Bridge.

Web site http://www.osti.gov/bridge

Reports produced before January 1, 1996, may be purchased by members of the public from the following source.

National Technical Information Service

5285 Port Royal Road

Springfield, VA 22161

Telephone 703-605-6000 (1-800-553-6847)

TDD 703-487-4639

Fax 703-605-6900

E-mail info@ntis.gov

Web site http://www.ntis.gov/support/ordernowabout.htm

Reports are available to DOE employees, DOE contractors, Energy Technology Data Exchange (ETDE) representatives, and International Nuclear Information System (INIS) representatives from the following source.

Office of Scientific and Technical Information

P.O. Box 62

Oak Ridge, TN 37831

Telephone 865-576-8401

Fax 865-576-5728

E-mail reports@osti.gov

Web site http://www.osti.gov/contact.html

This report was prepared as an account of work sponsored by an agency of the United States Government. Neither the United States Government nor any agency thereof, nor any of their employees, makes any warranty, express or implied, or assumes any legal liability or responsibility for the accuracy, completeness, or usefulness of any information, apparatus, product, or process disclosed, or represents that its use would not infringe privately owned rights. Reference herein to any specific commercial product, process, or service by trade name, trademark, manufacturer, or otherwise, does not necessarily constitute or imply its endorsement, recommendation, or favoring by the United States Government or any agency thereof. The views and opinions of authors expressed herein do not necessarily state or reflect those of the United States Government or any agency thereof. 
Energy and Transportation Science Division

\title{
ADVANCING RESIDENTIAL RETROFITS IN ATLANTA
}

\author{
Roderick K. Jackson \\ Eyu-Jin Kim \\ Sydney Roberts \\ Robert Stephenson
}

March 2012

Prepared by

OAK RIDGE NATIONAL LABORATORY

Oak Ridge, Tennessee 37831-6283

managed by

UT-BATTELLE, LLC

for the

U.S. DEPARTMENT OF ENERGY

under contract DE-AC05-00OR22725 


\section{Contents}

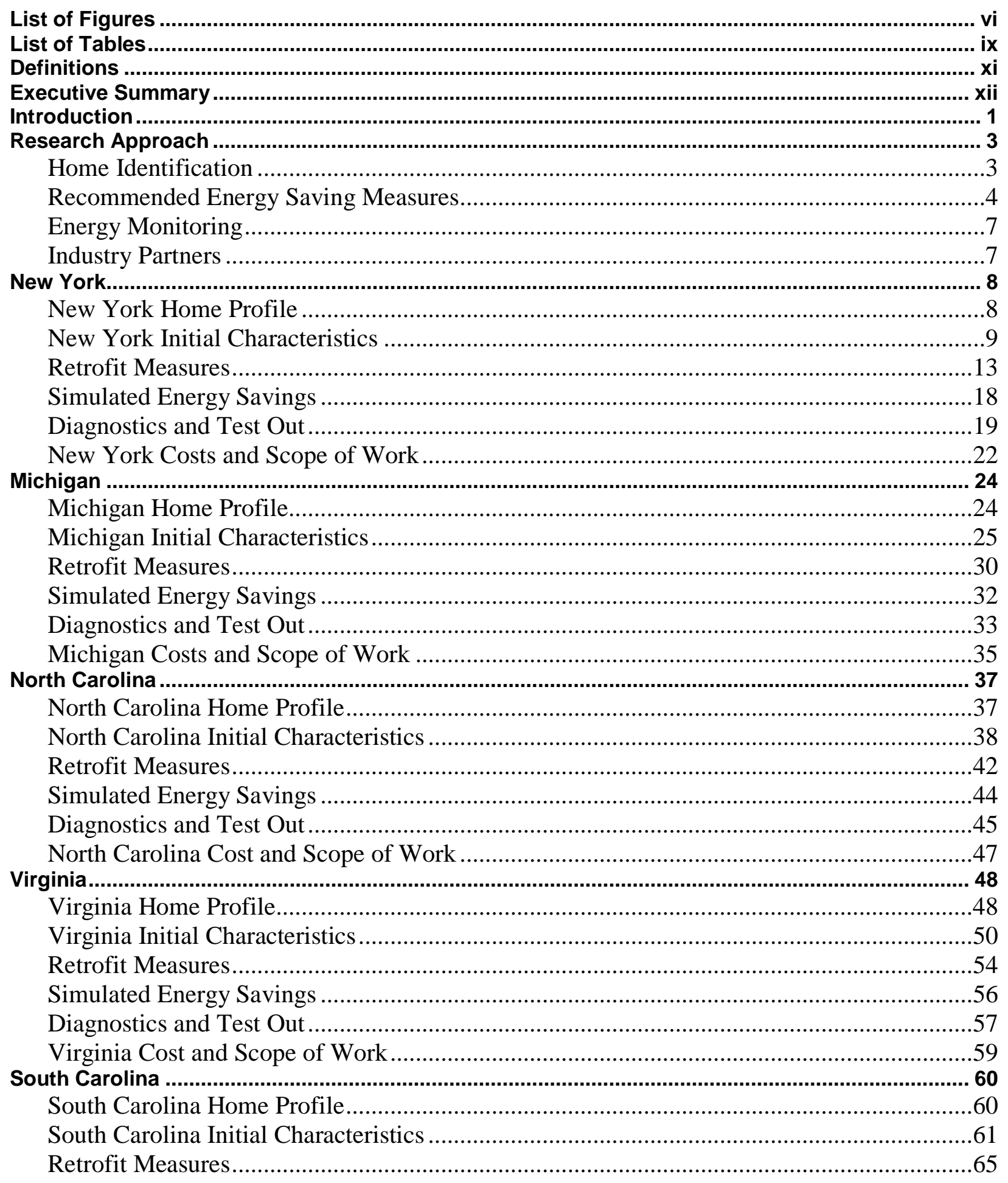




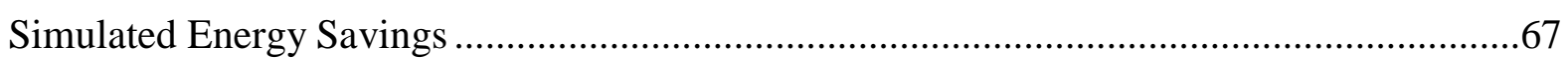

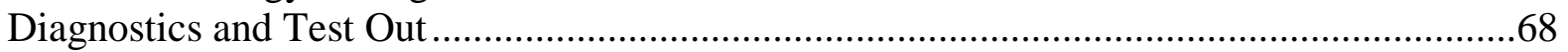

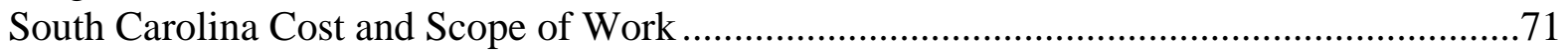

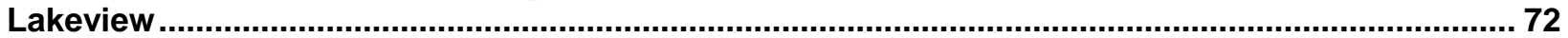

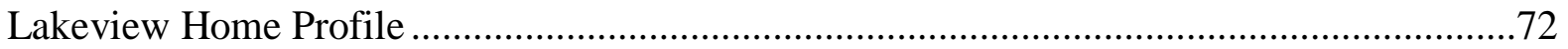

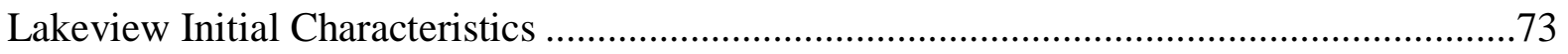

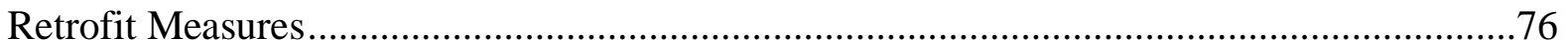

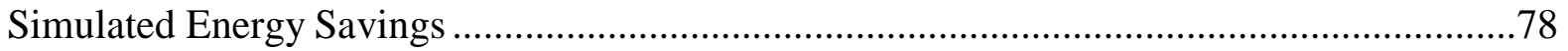

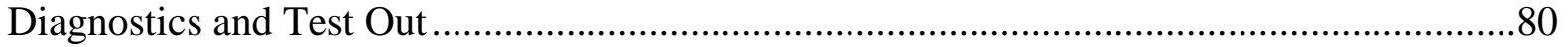

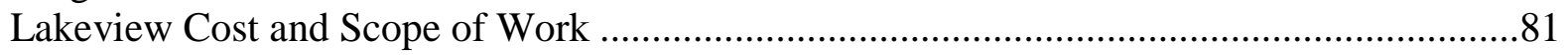

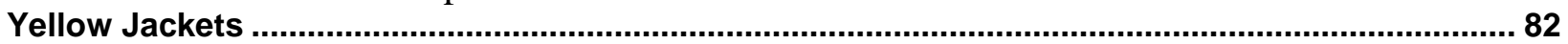

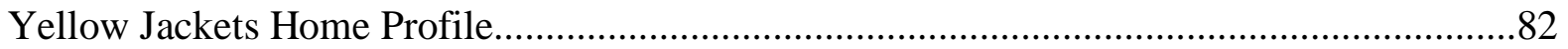

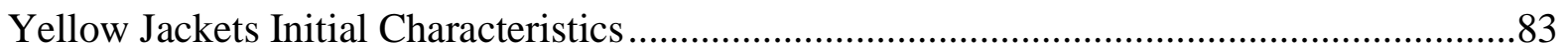

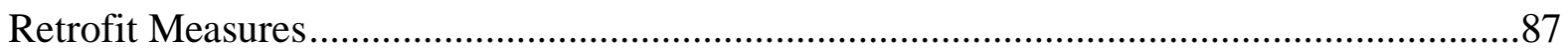

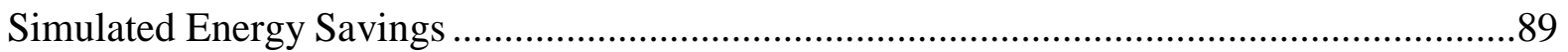

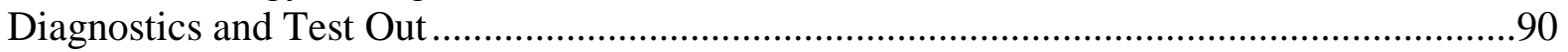

Yellow Jackets Cost and Scope of Work ................................................................92

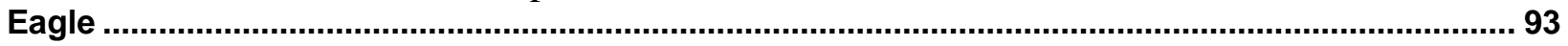

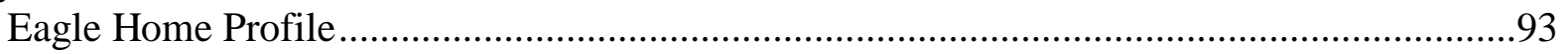

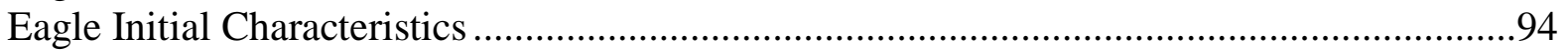

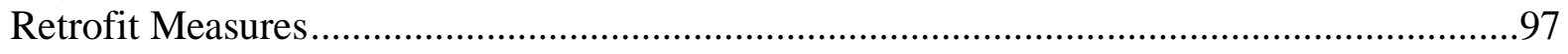

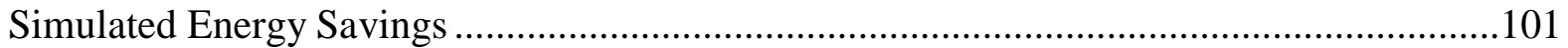

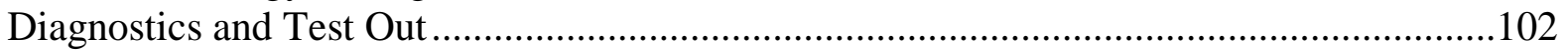

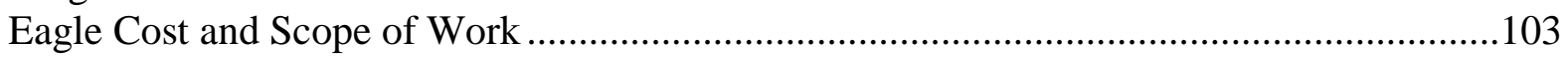

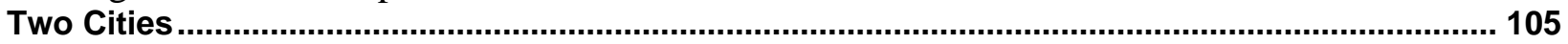

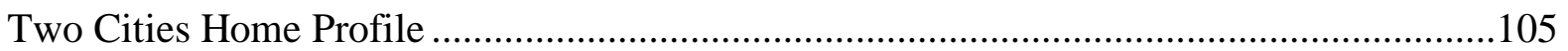

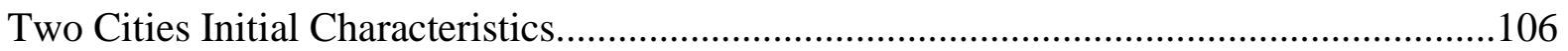

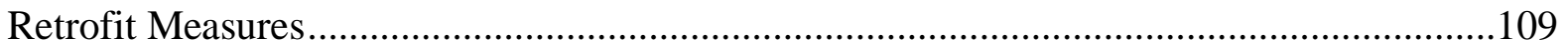

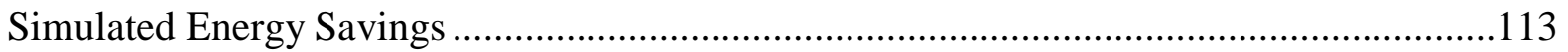

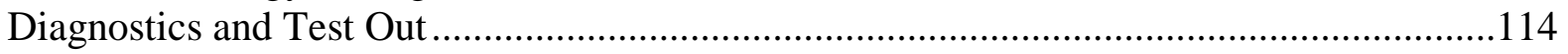

Two Cities Costs and Scope of Work …....................................................................115

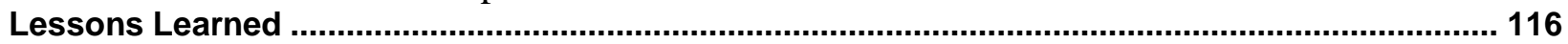

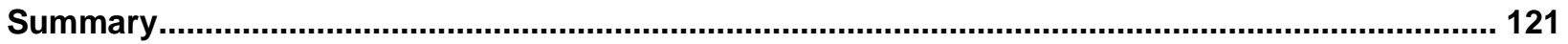




\section{List of Figures}

Figure 1. Approach used to determine retrofit measures .......................................................... 6

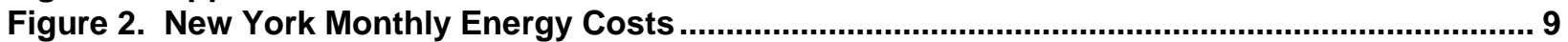

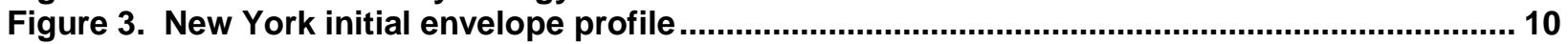

Figure 4. Thermal image of the exterior walls in the main section of the home (left image) and the

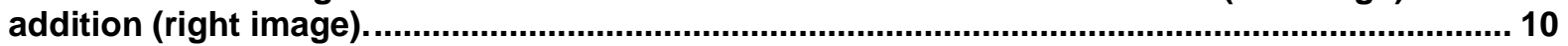

Figure 5. Photographs show examples of places in the exterior siding where rotting has occurred.11

Figure 6. Photograph of the air conditioner and heater used in the addition..................................12

Figure 7. Open-cell spray foam on the roofline and gables. ......................................................... 14

Figure 8. Illustration of building envelope after encapsulating the attic and crawlspace............... 15

Figure 9. Wall cavity in New York where an interior vapor barrier is present. ................................16

Figure 10. Spider insulation blown into the exposed cavities. ...................................................... 17

Figure 11. Photographs of the "drill-and-fill" installation of fiberglass insulation into the cavity walls. Image on the left shows the installer blowing fiberglass into the cavity. Two holes in each cavity can be seen in the image on the right. ................................................................17

Figure 12. Photograph of the rear view of the addition. The mini-split outdoor unit is highlighted

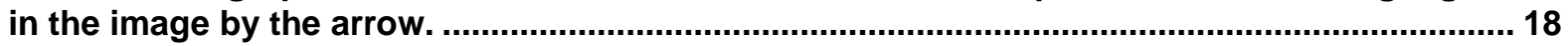

Figure 13. Simulated Energy Savings from Heating and Cooling Loads...................................... 19

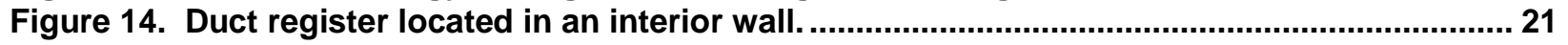

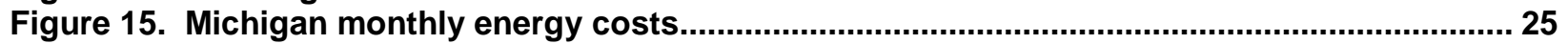

Figure 16. Illustration of Michigan's initial building envelope profile. ….................................... 25

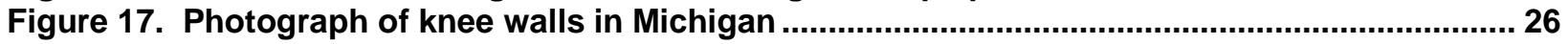

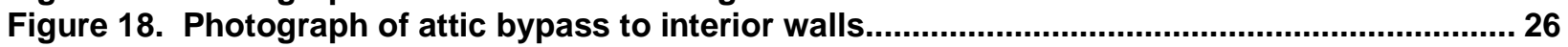

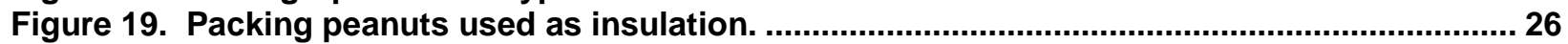

Figure 20. Thermal image of an exterior wall in Michigan. The arrow in the figure highlights the absence of insulation in the wall cavities between the studs. .................................................... 27

Figure 21. Photograph of an attic bypass in the exterior wall. .................................................. 27

Figure 22. Photograph of the R-13 batts installed in crawlspace ceiling.................................... 28

Figure 23. a) Photograph of rigid foam board applied in an attic bypass adjacent to an exterior wall. b) Photograph of open-cell spray foam applied in exterior wall bypasses. Insulation on knee walls is also shown in the picture.

Figure 24. Blown fiberglass insulation applied in the attic ceiling (R-38)..................................... 31

Figure 25. Simulated Energy Savings from Heating and Cooling Loads........................................ 33

Figure 26. Photograph of supply register located in the wall. ........................................................... 35

Figure 27. North Carolina monthly energy costs ...................................................................... 38

Figure 28. Illustration of North Carolina's initial building profile..................................................... 39

Figure 29. Attic bypasses. On the right is a thermal image of the attic access door. The blue color in the image shows attic air infiltration into the living space......................................... 39

Figure 30. Thermal image of an exterior wall in North Carolina. The arrow in the figure highlights the absence of insulation in the wall cavities between the studs............................................... 40

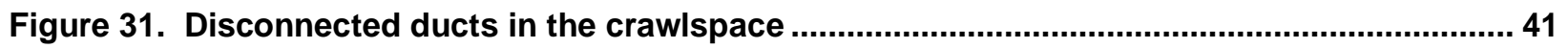

Figure 32. Insulation applied on the attic knee wall and the attic access door............................... 43

Figure 33. Crawlspace sealing and vapor barrier installation. The arrow in the picture on the right highlights the open-cell spray foam applied over the vapor barrier........................................... 43

Figure 34. Simulated Energy Savings from Heating and Cooling Loads ..................................... 45

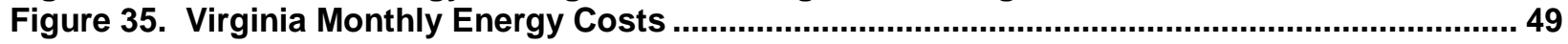

Figure 36. Virginia initial envelope profile ......................................................................... 50

Figure 37. Thermal image of an exterior wall in Virginia. The arrow in the figure highlights the absence of insulation in the wall cavities between the studs. .................................................51

Figure 38. R-13 insulation installed in a manner inconsistent with recommended approaches. ... 51

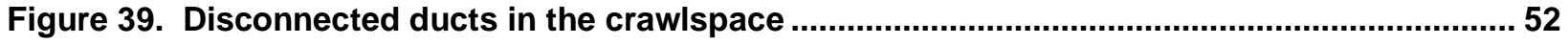

Figure 40. Fiberglass batts reinstalled in the crawlspace after air sealing....................................55

Figure 41. Photograph of the min-split system in Virginia. Indoor unit is shown in the image on the left. The outdoor refrigerant lines are shown in the image on the right..............................56 
Figure 42. Simulated Energy Savings from Heating and Cooling Loads....................................... 57

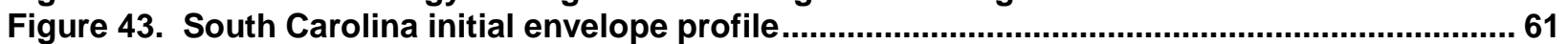

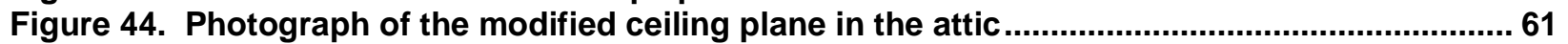

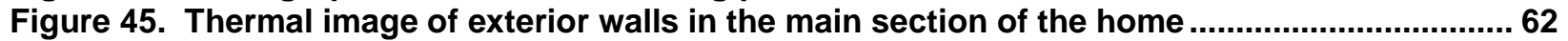

Figure 46. Thermal image of the exterior wall in the addition to the home. The arrow in the figure

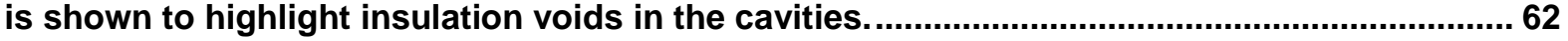

Figure 47. Ceiling insulation in the addition of South Carolina. The arrow in the figure highlights

gaps in the insulation where the ceiling was not insulated from the attic air.............................. 62

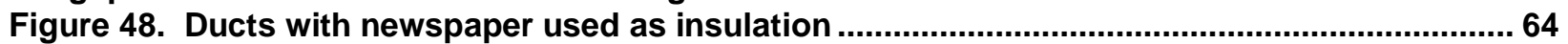

Figure 49. Photograph of attic after open-cell spray foam has been applied to the roofline .......... 66

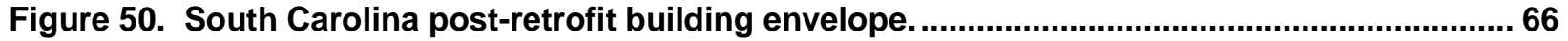

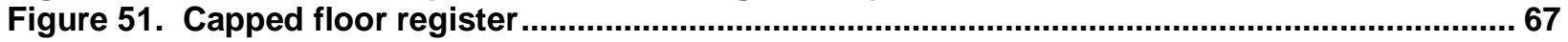

Figure 52. Simulated Energy Savings from Primary Building Loads ..............................................68

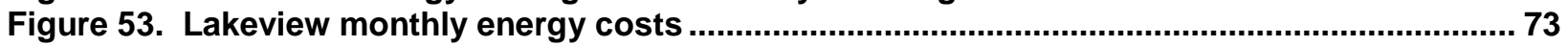

Figure 54. Illustration of the initial building envelope ............................................................... 73

Figure 55. Thermal image highlighting insulation voids in exterior walls.......................................74

Figure 56. Open cell spray foam applied in the roofline and gables ................................................ 77

Figure 57. Illustration of the new building envelope with the attic included in the conditioned

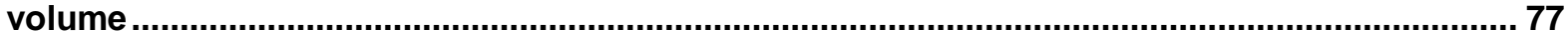

Figure 58. Solar thermal hot water panels installed on the garage roof........................................ 78

Figure 59. Simulated Energy Savings from Heating and Cooling Loads ....................................... 79

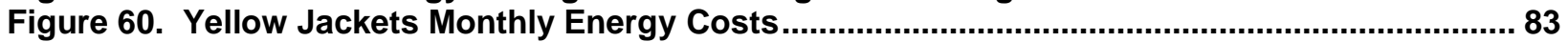

Figure 61. Yellow Jackets initial envelope profile. The arrow highlights the location of the FROG.84

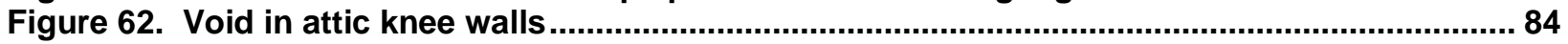

Figure 63. a) Thermal scan of an exterior wall. Voids in the insulation where the fiberglass batts

have sunk over time is illustrated by the arrow. b) Thermal scan of an interior wall................ 85

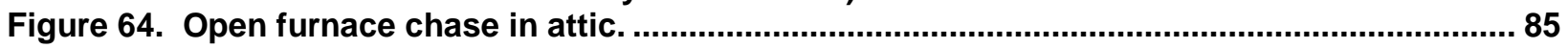

Figure 65. House wrap applied to Yellow Jackets before siding .................................................... 88

Figure 66. Yellow Jackets post-retrofit envelope profile. The gray in the photo represents the basement volume.

Figure 67. Insulated and sealed garage wall and ceiling. Arrows in the picture point to the spray

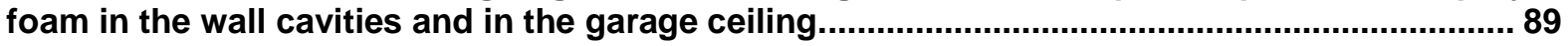

Figure 68. Simulated Energy Savings from Primary Building Loads .............................................. 90

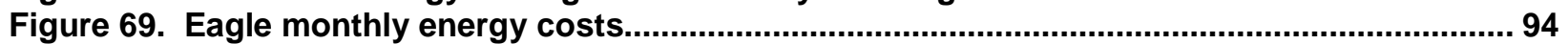

Figure 70. Illustration of the initial building envelope ..................................................................... 95

Figure 71. Thermal images that show significant air infiltration at baseboards (left) and door

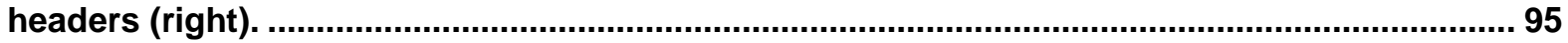

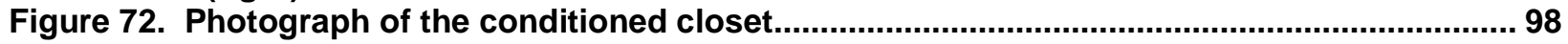

Figure 73. Photograph of the storage room area that has been converted to conditioned area....98

Figure 74. Illustration of the new building envelope after the addition area has been added. ....... 98

Figure 75. Photograph of open-cell spray foam in the wall cavities and ceiling rafters................. 99

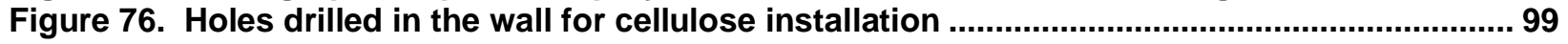

Figure 77. R-5 of closed-cell insulation sprayed on the band joist .............................................. 100

Figure 78. Simulated Energy Savings from Heating and Cooling Loads..................................... 102

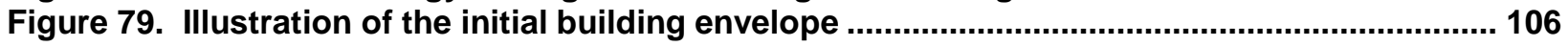

Figure 80. Photograph of the attic in Two Cities. The arrows in the figure are shown to highlight

the radiant barrier on the roofline and the continuous layer of fiberglass insulation on the attic

floor.

Figure 81. Open chase near the fireplace chimney and water heater flue................................... 107

Figure 82. Infiltration pathways found in Two Cities. The photograph on the left shows an open plumbing access underneath the tub. The image on the right shows a hole in the kitchen wall

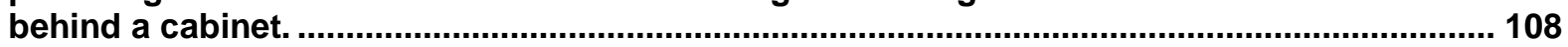

Figure 83. Spray foam insulation applied around the fireplace chase.......................................... 110

Figure 84. Drill and fill of cellulose insulation in the exterior wall cavities.................................... 110

Figure 85. Thermal image of the exterior wall to show the grade of the insulation installation. The white dots in the figure are the Styrofoam plugs placed in each cavity after being filled....... 111 
Figure 86. Spot energy recovery ventilator is shown in the image on the right. The initial wholehouse fan is shown in the figure on the left..................................................................... 112

Figure 87. Sun tunnel (left) and ENERGY STAR ceiling fan (right) ........................................... 112

Figure 88. Simulated Energy Savings from Heating and Cooling Loads...................................... 113 


\section{List of Tables}

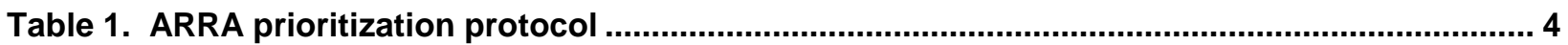

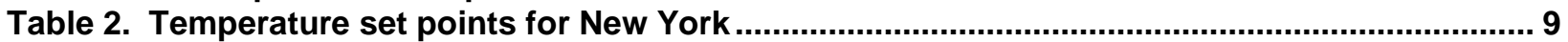

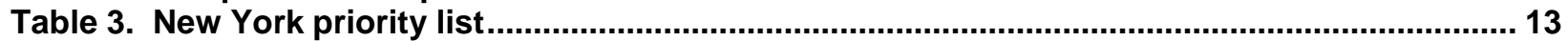

Table 4. New York recommended package with simulated energy savings from EnergyGauge.... 19

Table 5. Pre-retrofit and post-retrofit air infiltration diagnostics....................................................... 20

Table 6. Duct Blaster test results for New York house - duct leakage to outside measured as air flow at $25 \mathrm{~Pa}\left(\mathrm{CFM}_{25}\right)$ and normalized as a percentage $\left(\mathrm{CFM}_{25} / \mathrm{conditioned}\right.$ area $\left.\left(\mathrm{ft}^{2}\right)\right) \ldots \ldots \ldots \ldots . . . . .21$

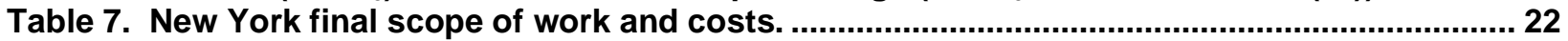

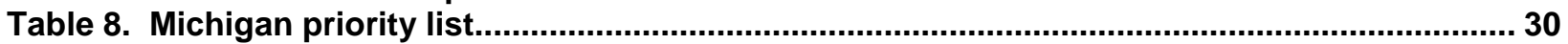

Table 9. Michigan recommended package with simulated energy savings from EnergyGauge .... 32

Table 10. Pre-retrofit and post-retrofit air infiltration diagnostics.................................................... 34

Table 11. Duct Blaster tests results for the Michigan house - duct leakage to outside measured as air flow at $25 \mathrm{~Pa}\left(\mathrm{CFM}_{25}\right)$ and normalized as a percentage $\left(\mathrm{CFM}_{25} /\right.$ conditioned area $\left.\left(\mathrm{ft}^{2}\right)\right)$..........34

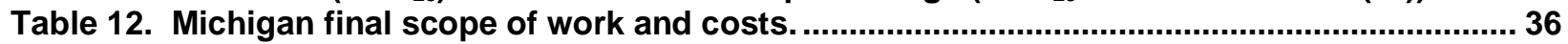

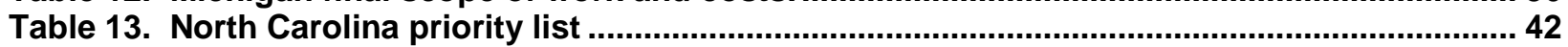

Table 14. North Carolina recommended package with simulated energy savings from

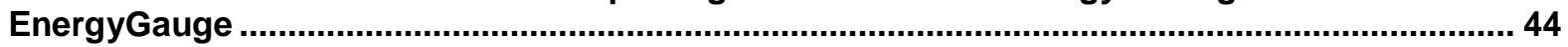

Table 15. Pre-retrofit and post-retrofit air infiltration diagnostics ................................................. 46

Table 16. Duct Blaster tests results - duct leakage to outside measured as air flow at $25 \mathrm{~Pa}$ $\left(\mathrm{CFM}_{25}\right)$ and normalized as a percentage $\left(\mathrm{CFM}_{25} /\right.$ conditioned area $\left.\left(\mathrm{ft}^{2}\right)\right)$...................................46

Table 17. North Carolina final scope of work and costs........................................................... 47

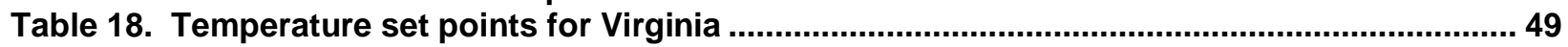

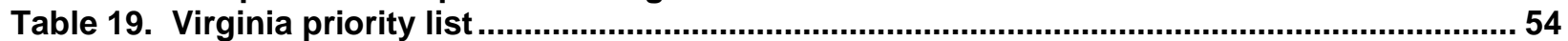

Table 20. Virginia recommended package with simulated energy savings from EnergyGauge..... 57

Table 21. Pre-retrofit and post-retrofit air infiltration diagnostics.................................................... 58

Table 22. Pre-retrofit and post-retrofit duct leakage diagnostics - duct leakage to outside measured as air flow at $25 \mathrm{~Pa}\left(\mathrm{CFM}_{25}\right)$ and normalized as a percentage $\left(\mathrm{CFM}_{25}\right.$ /conditioned

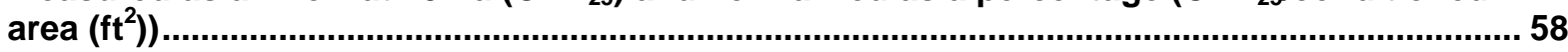

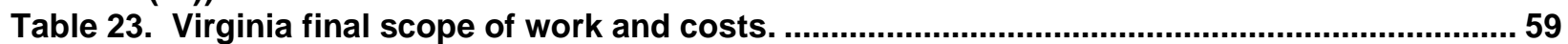

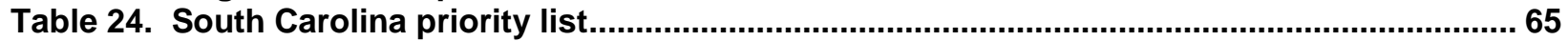

Table 25. South Carolina recommended package with simulated energy savings from

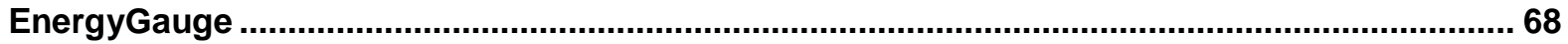

Table 26. Pre-retrofit and post-retrofit air infiltration diagnostics.................................................... 69

Table 27. Pre-retrofit and post-retrofit duct leakage diagnostics - duct leakage to outside measured as air flow at $25 \mathrm{~Pa}\left(\mathrm{CFM}_{25}\right)$ and normalized as a percentage (CFM ${ }_{25} /$ conditioned

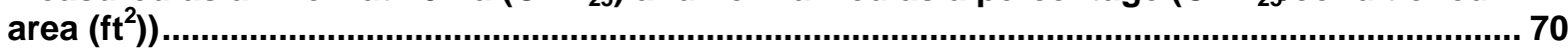

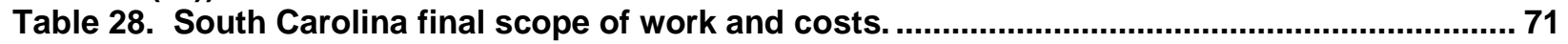

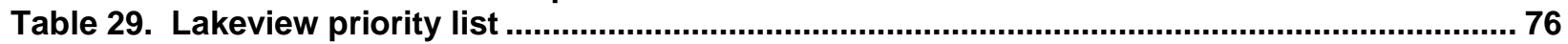

Table 30. Lakeview retrofit package with simulated energy savings from EnergyGauge ............... 79

Table 31. Pre-retrofit and post-retrofit air infiltration diagnostics .................................................... 80

Table 32. Pre-retrofit and post-retrofit duct leakage diagnostics - duct leakage to outside measured as air flow at $25 \mathrm{~Pa}\left(\mathrm{CFM}_{25}\right)$ and normalized as a percentage $\left(\mathrm{CFM}_{25} /\right.$ conditioned

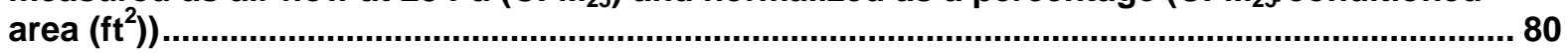

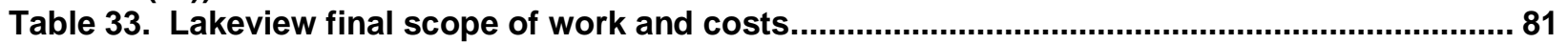

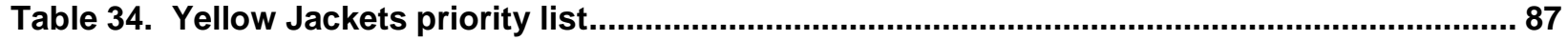

Table 35. Yellow Jackets recommended package with simulated energy savings from

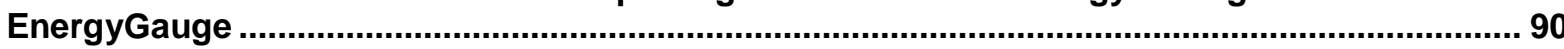

Table 36. Pre-retrofit and post-retrofit air infiltration diagnostics ................................................. 91

Table 37. Pre-retrofit and post-retrofit duct leakage diagnostics - duct leakage to outside measured as air flow at $25 \mathrm{~Pa}\left(\mathrm{CFM}_{25}\right)$ and normalized as a percentage $\left(\mathrm{CFM}_{25} /\right.$ conditioned area $\left.\left(\mathrm{ft}^{2}\right)\right)$

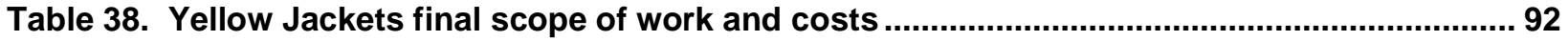

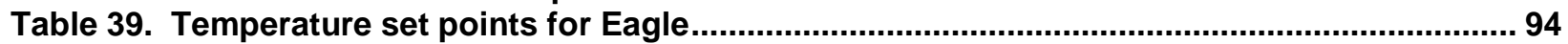


Table 40. Eagle priority list.

Table 41. Eagle recommended package with simulated energy savings from EnergyGauge ....... 101

Table 42. Pre-retrofit and post-retrofit air infiltration diagnostics............................................. 102

Table 43. Pre--retrofit and post-retrofit duct leakage diagnostics - duct leakage to outside measured as air flow at $25 \mathrm{~Pa}\left(\mathrm{CFM}_{25}\right)$ and normalized as a percentage $\left(\mathrm{CFM}_{25} /\right.$ conditioned area $\left.\left(\mathrm{ft}^{2}\right)\right)$.

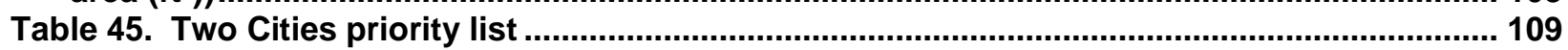

Table 46. Two Cities retrofit package with simulated energy savings from EnergyGauge ............ 113

Table 47. Pre-retrofit and post-retrofit air infiltration diagnostics ............................................ 114

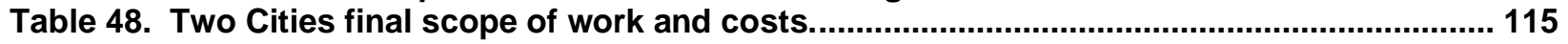




\section{Definitions}

$\mathrm{ACH}_{50}$

$\mathrm{ACH}_{\text {natural }}$

$\mathrm{A} / \mathrm{C}$

AFUE

ARRA

CFL

CFM

$\mathrm{CFM}_{25}$

$\mathrm{CFM}_{50}$

ERV

HERS

ORNL

PNNL
Air changes per hour at 50 Pascals, infiltration measurement

Estimated air changes per hour under natural conditions, infiltration measurement

Air conditioning

Annual fuel utilization efficiency

Advancing Residential Retrofits in Atlanta (title of this study

Compact fluorescent lamp

Cubic feet per minute, air flow volume measurement

Air flow (CFM) at 25 Pascals, duct leakage measurement

Air flow (CFM) at 50 Pascals, infiltration measurement

Energy Recovery Ventilator

Home Energy Rating System

Oak Ridge National Laboratory

Pacific Northwest National Laboratory 


\section{Executive Summary}

As part of a roadmap to foster the implementation of "deeper energy retrofits" at speed and scale, the Department of Energy's Building America program has set research goals to develop and demonstrate market ready retrofit solutions to reduce home energy use by $30-50 \%$ (compared to pre-retrofit energy use). To this end, researchers at Oak Ridge National Laboratory (ORNL) partnered with Pacific Northwest National Laboratory (PNNL) to conduct research on comprehensive energy retrofits implemented in several climate zones. PNNL researchers worked with homeowners and contractors to conduct research on home energy improvements in Florida, Texas, and Washington, while ORNL focused its efforts in the metropolitan Atlanta, Georgia area. This research was focused on determining "what it takes" to generate deep energy savings, which includes 1 ) what measures are necessary to achieve large energy savings, 2) the costs of these measures, 3) the difference between predicted energy savings and actual savings, 4) the "beyond-energy" benefits of home energy retrofits, and 5) the challenges to meeting the research goals of residential energy retrofits with energy savings of 30 - 50\%. Answering these research questions will be an important step advancing residential retrofits in the United States.

This report summarizes the home energy improvements performed in the Atlanta area (ORNL focus area). In total, nine homes were retrofitted with eight of the homes having predicted source energy savings of approximately $30 \%$ or greater based on simulated energy consumption (Figure ES1). Summaries of the retrofit measures taken in each home (aliases used to preserve home anonymity) are shown in the table below (Table ES1). While conventional retrofit measures such as air sealing and increased insulation were employed, 4 homes achieved significant energy savings from converting the attic to an unvented space with roofline insulation. This measure has the thermal benefit of reducing the heat gain/loss from the living space to the attic by disconnecting the attic volume from the outdoor environment. Additionally, this measure produces HVAC energy savings derived from the fact that the system is now located within the thermal and pressure boundary of the home. Also, three of the homes in this study had wall cavity insulation added through a drill-and-fill process.

In addition to detailed reports on all retrofits, lessons learned and observations are included in this report. Key items include the following:

- Challenges with regard to how energy savings are defined

- Obstacles to cost-effectively determining the building characteristics and diagnostics of a home prior to beginning the retrofit

- Need to determine and articulate the "beyond-energy” benefits of retrofit measures

- Technical challenges for specific retrofit measures

- Logistical challenges in regard to homeowners during the retrofit

- Retrofit costs (costs are both high and variable) 
The energy consumption of these homes will be monitored through monthly utility bills and inhome data monitors from September 2011 through August 2012, and compared to predicted consumption. A follow-up report will summarize the predicted versus actual energy savings.

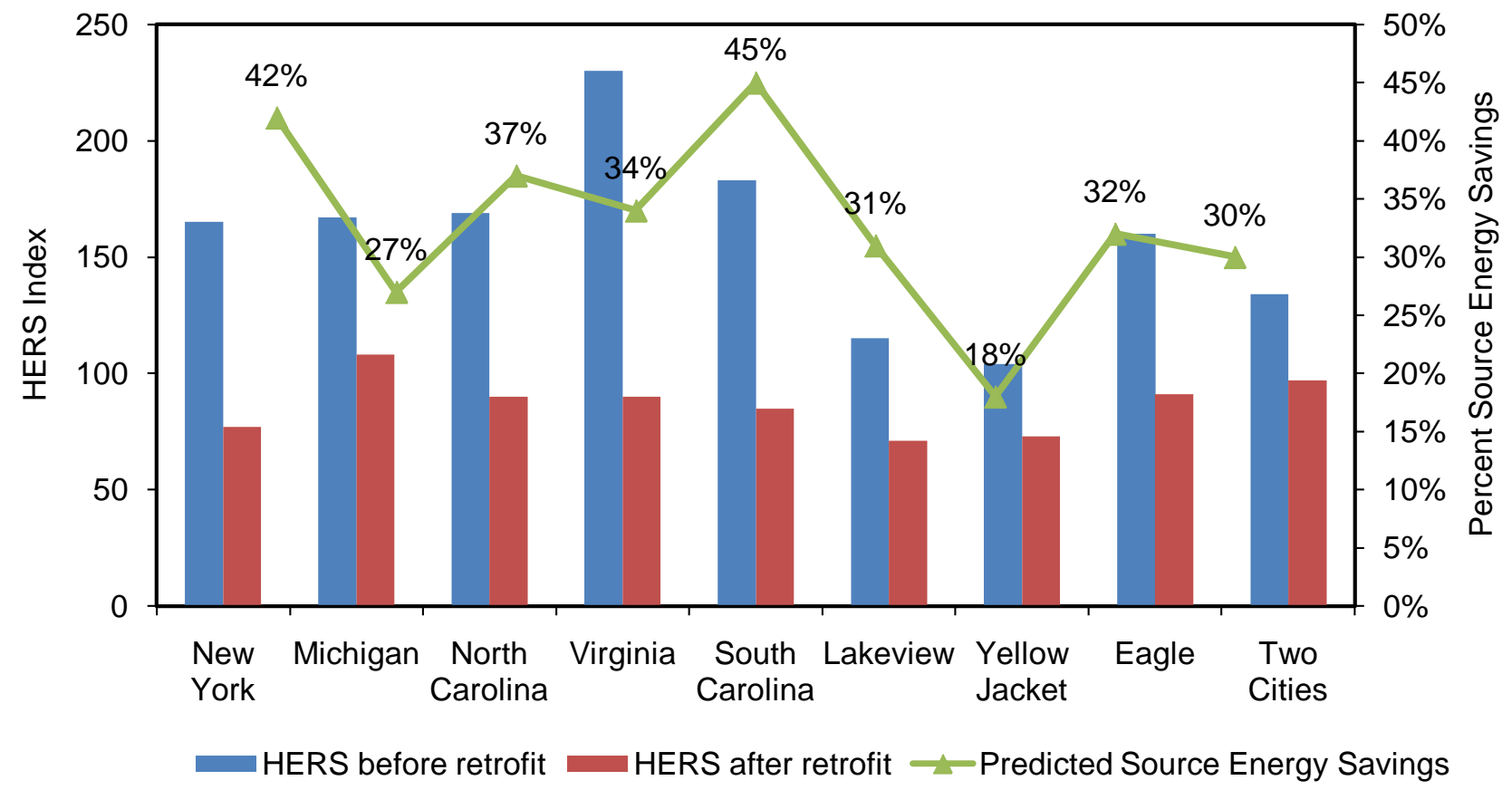

Figure ES1. Summary of the HERS indices before and after retrofits. On the right axis, the total estimated source energy savings are shown for each home. 
Table ES1. Summaries of retrofit measures taken in each home

\begin{tabular}{|c|c|c|c|c|c|c|c|c|c|}
\hline $\begin{array}{c}\text { Home } \\
\text { Alias } \\
\text { (square } \\
\text { footage) } \\
\end{array}$ & $\begin{array}{c}\text { Exterior } \\
\text { Walls } \\
\end{array}$ & Attic/Knee walls & Foundation & Cooling & Heating & DHW & Windows & Misc & $\begin{array}{l}\text { HERS } \\
\text { (pre- } \\
\text { retrofit / } \\
\text { post- } \\
\text { retrofit) } \\
\end{array}$ \\
\hline $\begin{array}{l}\text { New } \\
\text { York } \\
\left(3050 \mathrm{ft}^{2}\right)\end{array}$ & $\begin{array}{l}\text { Siding } \\
\text { removed and } \\
\text { replaced }\end{array}$ & $\begin{array}{l}\text { Attic encapsulated } \\
\text { with R- } 21 \text { open- } \\
\text { cell spray foam on } \\
\text { roofline }\end{array}$ & $\begin{array}{l}\text { R-13 (closed- } \\
\text { cell foam on } \\
\text { walls) } \\
\text { R-11 (open- } \\
\text { cell foam on } \\
\text { band) } \\
\text { New 12-mil } \\
\text { vapor barrier }\end{array}$ & $\begin{array}{l}3 \text { ton, } 14.5 \\
\text { SEER (1st floor) } \\
2.5 \text { ton, } 14.5 \\
\text { SEER } \\
19.2 \text { SEER } \\
\text { mini-split heat } \\
\text { pump }\end{array}$ & $\begin{array}{l}70 \text { kBtuh } \\
95 \\
\text { AFUE(2nd } \\
\text { floor) }\end{array}$ & $\begin{array}{l}2.4 \mathrm{EF} \\
\text { electric } \\
\text { heat pump } \\
\text { water } \\
\text { heater }\end{array}$ & $\begin{array}{l}\text { Double-pane } \\
\text { ENERGY } \\
\text { STAR for } \\
\text { front left } \\
\text { window }\end{array}$ & & $\begin{array}{l}(165 / 77) \\
\underline{\text { Projected }} \\
\underline{\text { source }} \\
\underline{\text { energy }} \\
\underline{\text { savings: }} \\
42 \%\end{array}$ \\
\hline $\begin{array}{l}\text { Michigan } \\
\left(3380 \mathrm{ft}^{2}\right)\end{array}$ & & $\begin{array}{l}\text { R-38 blown } \\
\text { fiberglass (flat } \\
\text { ceiling) } \\
\text { R-15 open-cell } \\
\text { foam(knee walls) } \\
\text { Attic bypasses air } \\
\text { sealed; } \\
\text { Whole house fan } \\
\text { removed and } \\
\text { sealed; } \\
\text { Chimney capped }\end{array}$ & $\begin{array}{l}\text { Air sealing } \\
\text { around chases } \\
\text { and } \\
\text { penetrations; } \\
\text { Reinstalled } \\
\text { batt insulation } \\
\text { R-11 open-cell } \\
\text { spray foam on } \\
\text { crawlspace } \\
\text { band; } \\
\text { New 12-mil } \\
\text { vapor barrier }\end{array}$ & $\begin{array}{l}3.5 \text { ton, } 14.5 \\
\text { SEER (Main) } \\
2 \text { ton } 14.5 \text { SEER } \\
\text { (Master suite) }\end{array}$ & $\begin{array}{l}89 \text { kBtuh } \\
95 \text { AFUE } \\
\text { (Main) }\end{array}$ & & & & $\begin{array}{l}\text { (167 / 108) } \\
\text { Projected } \\
\underline{\text { source }} \\
\text { energy } \\
\text { savings: } \\
27 \%\end{array}$ \\
\hline
\end{tabular}




\begin{tabular}{|c|c|c|c|c|c|c|c|c|c|}
\hline $\begin{array}{c}\text { Home } \\
\text { Alias } \\
\text { (square } \\
\text { footage) }\end{array}$ & $\begin{array}{c}\text { Exterior } \\
\text { Walls }\end{array}$ & Attic/Knee walls & Foundation & Cooling & Heating & DHW & Windows & Misc & $\begin{array}{l}\text { HERS } \\
\text { (pre- } \\
\text { retrofit / } \\
\text { post- } \\
\text { retrofit) }\end{array}$ \\
\hline $\begin{array}{l}\text { North } \\
\text { Carolina } \\
\left(3710 \mathrm{ft}^{2}\right)\end{array}$ & & $\begin{array}{l}\text { R-38 blown } \\
\text { fiberglass and } \\
\text { other air sealing } \\
\text { measures / } \\
\text { R-15 open-cell } \\
\text { foam }\end{array}$ & $\begin{array}{l}\text { R-13 (closed- } \\
\text { cell foam on } \\
\text { walls), } \\
\text { R-11 (open- } \\
\text { cell foam on } \\
\text { band), } \\
\text { New vapor } \\
\text { barrier applied }\end{array}$ & $\begin{array}{l}3 \text { ton, } 16 \text { SEER } \\
\text { (first floor) } \\
2.5 \text { ton, } 16 \\
\text { SEER (second } \\
\text { floor) }\end{array}$ & & $\begin{array}{l}50 \text { gal. } 2.0 \\
\text { EF Rheem } \\
\text { Heat Pump } \\
\text { Water } \\
\text { Heater }\end{array}$ & & & $\begin{array}{l}(169 / 90) \\
\text { Projected } \\
\text { source } \\
\text { energy } \\
\text { savings: } \\
37 \%\end{array}$ \\
\hline $\begin{array}{l}\text { Virginia } \\
\left(2920 \mathrm{ft}^{2}\right)\end{array}$ & & $\begin{array}{l}\text { R-38 blown } \\
\text { fiberglass/ } \\
\text { R-15 open-cell } \\
\text { foam }\end{array}$ & $\begin{array}{l}\text { Air-seal and } \\
\text { reinstall } \\
\text { existing R-13 } \\
\text { batts so that } \\
\text { the paper side } \\
\text { of the } \\
\text { insulation } \\
\text { contacts the } \\
\text { subfloor; } \\
\text { R-11 } \\
\text { insulation } \\
\text { added to } \\
\text { crawlspace } \\
\text { band; new } \\
\text { vapor barrier } \\
\text { applied }\end{array}$ & $\begin{array}{l}2 \text { ton, } 14.5 \\
\text { SEER (first } \\
\text { floor) } \\
\\
3 \text { ton, } 19.2 \\
\text { SEER mini-split } \\
\text { (second floor) }\end{array}$ & $\begin{array}{l}90 \text { kBtuh, } \\
95 \text { AFUE }\end{array}$ & & $\begin{array}{l}\text { Two east- } \\
\text { facing (front) } \\
\text { windows } \\
\text { replaced with } \\
\text { ENERGY } \\
\text { STAR } \\
\text { double-pane; } \\
\text { U=.21; } \\
\text { SHGC=.30 }\end{array}$ & & $\begin{array}{l}(230 / 90) \\
\text { Projected } \\
\text { source } \\
\text { energy } \\
\text { savings: } \\
34 \%\end{array}$ \\
\hline
\end{tabular}




\begin{tabular}{|c|c|c|c|c|c|c|c|c|c|}
\hline $\begin{array}{c}\text { Home } \\
\text { Alias } \\
\text { (square } \\
\text { footage) }\end{array}$ & $\begin{array}{c}\text { Exterior } \\
\text { Walls }\end{array}$ & Attic/Knee walls & Foundation & Cooling & Heating & DHW & Windows & Misc & $\begin{array}{l}\text { HERS } \\
\text { (pre- } \\
\text { retrofit / } \\
\text { post- } \\
\text { retrofit) }\end{array}$ \\
\hline $\begin{array}{l}\text { Yellow } \\
\text { Jacket } \\
\left(3170 \mathrm{ft}^{2}\right)\end{array}$ & $\begin{array}{l}\text { R-18 open- } \\
\text { cell spray } \\
\text { foam on } \\
\text { garage } \\
\text { ceiling/ } \\
\text { R-11 on the } \\
\text { garage wall }\end{array}$ & $\begin{array}{l}\text { Attic encapsulated } \\
\text { with R-21 open- } \\
\text { cell spray foam on } \\
\text { roofline }\end{array}$ & $\begin{array}{l}\mathrm{R}-11 \text { open-cell } \\
\text { spray foam on } \\
\text { basement band }\end{array}$ & $\begin{array}{l}3 \text { ton } 14 \text { SEER } \\
\left(2^{\text {nd }} \text { Floor }\right)\end{array}$ & $\begin{array}{l}70 \text { kBtuh } \\
95 \text { AFUE } \\
\left(2^{\text {nd }} \text { Floor }\right)\end{array}$ & $\begin{array}{l}50 \text { gallon } \\
\text { A.O. } \\
\text { Smith } \\
\text { Vertex® } \\
\text { water } \\
\text { heater }\end{array}$ & & & $\begin{array}{l}(104 / 73) \\
\frac{\text { Projected }}{\text { source }} \\
\text { energy } \\
\frac{\text { savings: }}{18 \%}\end{array}$ \\
\hline
\end{tabular}




\begin{tabular}{|c|c|c|c|c|c|c|c|c|c|}
\hline $\begin{array}{c}\text { Home } \\
\text { Alias } \\
\text { (square } \\
\text { footage) }\end{array}$ & $\begin{array}{c}\text { Exterior } \\
\text { Walls }\end{array}$ & Attic/Knee walls & Foundation & Cooling & Heating & DHW & Windows & Misc & $\begin{array}{l}\text { HERS } \\
\text { (pre- } \\
\text { retrofit / } \\
\text { post- } \\
\text { retrofit) }\end{array}$ \\
\hline $\begin{array}{l}\text { Eagle } \\
\left(1320 \mathrm{ft}^{2}\right)\end{array}$ & $\begin{array}{l}\text { R-13 blown } \\
\text { cellulose } \\
\text { (main); } \\
\\
\text { R-15 open- } \\
\text { cell spray } \\
\text { foam (storage } \\
\text { room and } \\
\text { conditioned } \\
\text { closet) }\end{array}$ & 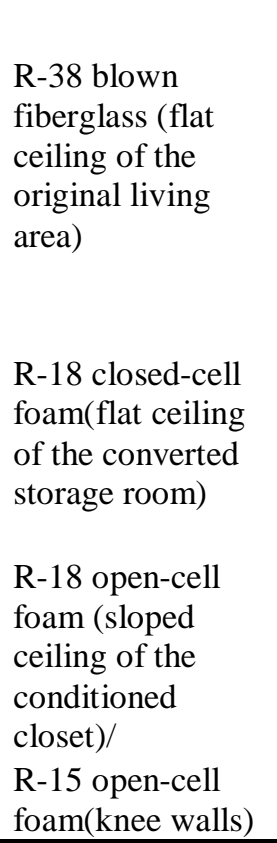 & $\begin{array}{l}\text { R-18 closed- } \\
\text { cell spray } \\
\text { foam on } \\
\text { crawlspace } \\
\text { band; }\end{array}$ & 2 ton, 18 SEER & $\begin{array}{l}9.5 \text { HSPF } \\
\text { mini-split } \\
\text { heat } \\
\text { pump; } 95 \\
\text { AFUE } \\
\text { natural gas } \\
\text { furnace }\end{array}$ & & & & $\begin{array}{l}(160 / 91) \\
\text { Projected } \\
\begin{array}{l}\text { source } \\
\text { energy }\end{array} \\
\text { savings: } \\
32 \%\end{array}$ \\
\hline $\begin{array}{l}\text { Two } \\
\text { Cities } \\
\left(1110 \mathrm{ft}^{2}\right)\end{array}$ & $\begin{array}{l}\text { R-13 blown } \\
\text { cellulose }\end{array}$ & & $\begin{array}{l}\text { R-18 } \\
\text { medium- } \\
\text { density open- } \\
\text { cell foam on } \\
\text { subfloor }\end{array}$ & $\begin{array}{l}\text { Programmable } \\
\text { thermostat } \\
\text { added }\end{array}$ & & & $\begin{array}{l}\text { Double-pane } \\
\text { fiberglass on } \\
\text { two } \\
\text { windows. } \\
\text { One single- } \\
\text { pane window } \\
\text { removed. }\end{array}$ & $\begin{array}{l}\text { ENERGY } \\
\text { STAR } \\
\text { washer, } \\
\text { ceiling fans, } \\
\text { dishwasher, } \\
\text { refrigerator, } \\
\text { oven and } \\
\text { stove; high- } \\
\text { efficient } \\
\text { clothes dryer, } \\
\text { exterior } \\
\text { lighting }\end{array}$ & $\begin{array}{l}(134 / 97) \\
\text { Projected } \\
\text { source } \\
\text { energy } \\
\text { savings: } \\
30 \%\end{array}$ \\
\hline
\end{tabular}




\section{Introduction}

In an effort to improve the national economy and strengthen the nation's energy future, residential retrofits have been identified as a key resource due to their ability to save homeowners money, create local jobs, and reduce building energy consumption. National initiatives such as Home Energy Score ${ }^{1}$, the PowerSaver ${ }^{2}$ loan program, and the Better Buildings ${ }^{3}$ program are all examples of the focus residential retrofits have received from a national level.

While increasing home energy efficiency is a national goal, there has been only limited success in engaging large numbers of homeowners to pursue comprehensive home energy improvements. In contrast, when homeowners do make the conscious decision to increase their home's energy efficiency, it is often done in a "single measure implementation" approach. In other words, a homeowner may decide to buy a more energy efficient water heater or buy a more energy efficient HVAC system; however, they don't often decide to do both at the same time. While it is commendable that homeowners are more energy conscious and consider energy efficiency when making a purchase decision, to meet the goals outlined in the Recovery Through Retrofits ${ }^{4}$ report, more comprehensive energy improvements (i.e. “deeper energy retrofits”) are needed.

As part of a roadmap to foster the implementation of "deeper energy retrofits" at speed and scale, the Department of Energy’s Building America program has set research goals to develop and demonstrate market ready retrofit solutions to reduce home energy use by 30 - 50\% (compared to pre-retrofit energy use). To this end, researchers at Oak Ridge National Laboratory (ORNL) partnered with Pacific Northwest National Laboratory (PNNL) to conduct research on comprehensive energy retrofits implemented in different climate zones. PNNL researchers worked with homeowners and contractors to conduct research on home energy improvements in Florida, Texas, and Washington, while ORNL focused its efforts in the metropolitan Atlanta, Georgia area. This research was focused on determining "what it takes" to generate deep energy savings, which includes 1) what measures are necessary to achieve large energy savings, 2) the costs of these measures, 3) the difference between predicted energy savings and actual savings, 4) the "beyond-energy" benefits of home energy retrofits, and 5) the challenges to meeting the research goals of residential energy retrofits with energy savings of $30-50 \%$. Answering these research questions will be an important step advancing residential retrofits in the United States.

ORNL contracted with Southface Energy Institute (Southface) to identify homeowners willing to complete "deep energy retrofits" while participating in this study in the metropolitan Atlanta area. In addition to allowing researchers to document the progress of the home energy retrofit, homeowners consented to providing at least one year of energy bills prior to the retrofit and one year of utility bills after the retrofit. Each homeowner also agreed to allow ORNL to monitor their energy consumption through in-home energy dataloggers. In return, ORNL worked with Southface to provide technical assistance with regard to the projected impact of various retrofit

\footnotetext{
${ }^{1}$ http://www1.eere.energy.gov/buildings/homeenergyscore/

2 http://portal.hud.gov/hudportal/HUD?src=/program_offices/housing/sfh/title/ti_home

${ }^{3}$ http://www1.eere.energy.gov/buildings/betterbuildings/

${ }^{4}$ http://www.whitehouse.gov/assets/documents/Recovery_Through_Retrofit_Final_Report.pdf
} 
measures. While energy savings was a primary figure of merit, the homeowners and contractors were advised on issues related to health and safety, home durability, and overall comfort.

This report summarizes the home energy improvements performed in the Atlanta area. This results presented in this report are interim, in that they only include details of the retrofits and their projected energy impact. A follow-up report will be written in 2012 following the collection of one year of monitored energy consumption data to compare the actual energy savings in comparison to the projected energy savings, in addition to other beyond-energy impacts the retrofit produced. In addition to the technical assistance provided by ORNL and Southface to facilitate the deep energy retrofits described in this report, key industry partners included Southern Company, A.O. Smith, and Johns Manville. By providing the retrofit details included in this report, and the validated savings in a follow-up report, this study will be a key component to “Advancing Residential Retrofits in Atlanta”. 


\section{Research Approach}

\section{Home Identification}

In addition to communicating the forthcoming retrofit study and recruiting homeowners to participate, Southface engaged home performance contractors that had substantial home energy retrofit experience in the Georgia Power Home Performance with ENERGY STAR (HPwES) program. The researchers felt that these contractors already had the required training to effectively implement whole-house energy efficiency improvements and would be able to qualify their existing customer base with regard to those who would be interested in making a substantial investment in energy efficiency.

An initial screening criterion was developed for potential homes. A summary is provided below:

- $\quad$ No less than five years old

- Occupied year round (not seasonally)

- Windows not frequently open when heating or cooling system is on

- Has central heating and cooling system

- No smoking allowed inside

- Does not have energy-intensive home-based businesses or hobbies

- Does not have a swimming pool

- Does not have a whole-house fan, or if it does, the fan is not operated

Once homeowners were identified and agreed to participate in the study, Southface conducted a test-in ${ }^{5}$ of each home. The test-in included the following:

- homeowner interview,

- building characterization

- Blower Door depressurization test,

- infrared infiltration test,

- duct leakage test,

- combustion safety test ${ }^{6}$, and

- $\quad$ air handler flow and pressure test.

The homeowner interview was used to determine behavioral factors that can influence home energy consumption, in addition to providing insight into the overall thermal comfort of the home. Information gathered in the interview included thermostat settings, comfort of individual rooms, and general comments by the homeowner.

To provide a unique identifier for each home in this retrofit study, while also protecting home anonymity, aliases were determined for each home. The alias for each home is as follows:

- New York

- North Carolina

\footnotetext{
5 “Test-in" is used to describe the pre-retrofit energy audit.

${ }^{6}$ BPI Building Analyst Technical Standards
} 
- South Carolina

- Virginia

- Michigan

- Yellow Jackets

- Lakeview

- Two Cities

- Eagle

The aliases are generic and do not reveal the location of the homes.

\section{Recommended Energy Saving Measures}

In working with homeowners and retrofit contractors to identify recommended retrofit measures, a consistent methodology was applied in this study, to provide a suggested approach to deploying deep energy retrofits. As described in the Recovery Through Retrofits report, a barrier to a national retrofit market is that "consumers do not have access to straightforward and reliable information on home energy retrofits that they need to make informed decisions" 7 . Even when homeowners are interested in increasing the energy efficiency of their home, there is no consistent recommended set of measures or approach to take. It is probable that their retrofit package will be prioritized around the expertise/market sector of contractor they most trust. For example, if they choose a retrofit contractor who specializes in HVAC installation and repair, their retrofit package will likely include HVAC system treatment. In contrast, we believe it would be very useful to use a prioritization protocol (without the personal bias that a specific contractor may have) to suggest an initial set of retrofit measures as a discussion basis with a chosen contractor. The prioritization protocol used in this study is shown in Table 1 . This protocol is based on a priority list developed by Southface in 2003 based on experience with existing home retrofit projects and the feedback of industry experts for the Georgia Power Home Performance with ENERGY STAR ${ }^{\circledR}$ program. Because of the evolution in equipment efficiencies, such as for HVAC equipment, modifications to the original protocol were needed and are documented in the table.

Table 1. ARRA prioritization protocol

\begin{tabular}{|l|l|c|l|}
\hline Improvement & Existing condition & Priority & $\begin{array}{l}\text { Modifications to the } \\
\text { original 2003 Southface } \\
\text { protocol }\end{array}$ \\
\hline Air sealing & $\geq 0.75 \mathrm{ACH}_{\text {natural }}$ & $\mathrm{A}$ & \\
\hline Air sealing & $0.50-0.74 \mathrm{ACH}$ natural & $\mathrm{B}$ & \\
\hline Air sealing & $0.4-0.49 \mathrm{ACH}_{\text {natural }}$ & $\mathrm{C}$ & \\
\hline Improve ducts & $\geq 25 \%$ duct leakage & $\mathrm{A}$ & \\
\hline Improve ducts & $16-24.9 \%$ duct leakage & $\mathrm{B}$ & \\
\hline Improve ducts & $10-15.9 \%$ duct leakage & $\mathrm{C}$ & \\
\hline Improve ducts & $5-9.9 \%$ duct leakage & $\mathrm{D}$ & \\
\hline $\begin{array}{l}\text { Insulate ATTIC (attic floor air } \\
\text { sealing must precede } \\
\text { insulation work) }\end{array}$ & R-0-R-9 & $\mathrm{A}$ & \\
\hline Insulate ATTIC (attic floor air & R-10-R-19 & $\mathrm{B}$ & \\
\hline
\end{tabular}

\footnotetext{
${ }^{7}$ http://www.whitehouse.gov/assets/documents/Recovery_Through_Retrofit_Final_Report.pdf

${ }^{8}$ Percentage duct leakage is determined as a ratio of the duct leakage to conditioned floor area $\left(\mathrm{cfm} / \mathrm{ft}^{2}\right)$
} 


\begin{tabular}{|c|c|c|c|}
\hline $\begin{array}{l}\text { sealing must precede } \\
\text { insulation work) }\end{array}$ & & & \\
\hline $\begin{array}{l}\text { Insulate ATTIC (attic floor air } \\
\text { sealing must precede } \\
\text { insulation work) }\end{array}$ & R-20-R-29 & $\mathrm{C}$ & \\
\hline $\begin{array}{l}\text { Insulate ATTIC KNEE } \\
\text { WALLS }\end{array}$ & None & A & \\
\hline $\begin{array}{l}\text { Insulate ATTIC KNEE } \\
\text { WALLS }\end{array}$ & $\begin{array}{l}\text { Insulated, unsheathed or } \\
\text { incomplete sheathing }\end{array}$ & B & \\
\hline $\begin{array}{l}\text { Insulate ATTIC KNEE } \\
\text { WALLS }\end{array}$ & $\begin{array}{l}\text { Insulated, sheathed, but only } \\
\text { effective R-13 }\end{array}$ & $\mathrm{D}$ & \\
\hline Insulate WALLS & None & $\mathrm{C}$ & \\
\hline Insulate FLOOR & None & B & \\
\hline Insulate FLOOR & Any & $\mathrm{C}$ & \\
\hline $\begin{array}{l}\text { Insulate } \\
\text { BASEMENT/CRAWLSPACE } \\
\text { WALLS }\end{array}$ & None & B & \\
\hline $\begin{array}{l}\text { Insulate } \\
\text { BASEMENT/CRAWLSPACE } \\
\text { WALLS }\end{array}$ & Any & $\mathrm{C}$ & \\
\hline Radiant barrier & No radiant barrier & $\mathrm{D}$ & \\
\hline Replace heating system & 60-69 AFUE / 5 HSPF & A & \\
\hline Replace heating system & 70-79 AFUE / 6 HSPF & B & $\begin{array}{l}\text { Upgraded from } C \text { due to } \\
\text { equipment improvements }\end{array}$ \\
\hline Replace heating system & 80-89 AFUE / 7 HSPF & $\mathrm{C}$ & $\begin{array}{l}\text { Upgraded from } \mathrm{D} \text { due to } \\
\text { equipment improvements }\end{array}$ \\
\hline Replace cooing system & 6-7.9 SEER & A & \\
\hline Replace cooing system & 8-9.9 SEER & A & $\begin{array}{l}\text { Upgraded from B due to } \\
\text { equipment improvements }\end{array}$ \\
\hline Replace cooing system & 10 SEER & B & $\begin{array}{l}\text { Upgraded from D due to } \\
\text { equipment improvements }\end{array}$ \\
\hline Replace water heater & $<0.5$ gas, $<0.85$ electric & B & $\begin{array}{l}\text { Upgraded from } \mathrm{C} \text { due to } \\
\text { equipment improvements }\end{array}$ \\
\hline Replace water heater & $<0.56$ gas,$<0.89$ electric & $\mathrm{C}$ & $\begin{array}{l}\text { Upgraded from D due to } \\
\text { equipment improvements }\end{array}$ \\
\hline Insulate water heater and pipe & electric & B & \\
\hline Insulate water heater and pipe & gas & $\mathrm{C}$ & \\
\hline Improve windows & Jalousie windows & A & \\
\hline Improve windows & Metal single pane & B & \\
\hline Improve windows & Wood single pane & $\mathrm{C}$ & \\
\hline Improve windows & Metal single pane with storm & $\mathrm{C}$ & \\
\hline Improve windows & Wood single pane with storm & $\mathrm{D}$ & \\
\hline Improve windows & Metal double pane & $\mathrm{D}$ & \\
\hline
\end{tabular}

The researchers in this study understand that each house is unique and a standard protocol will not work in all circumstances. With this in mind, the prioritization protocol is intended to serve as a resource for home performance contractors to supplement expertise and experience, not as a substitute. As shown in the approach taken to derive a list of suggested retrofit measures for each home (Figure 1), the recommended measures from the prioritization protocol are modeled and subsequently discussed by the building science team of researchers from ORNL and Southface. When modifications are needed to comply with best practices or because of circumstances unique to the home, the list is revised and its associated energy saving potential is 
modeled. Similarly, it was expected that in practice, the recommended measures from the prioritization list would be evaluated by the homeowner and retrofit contractor.

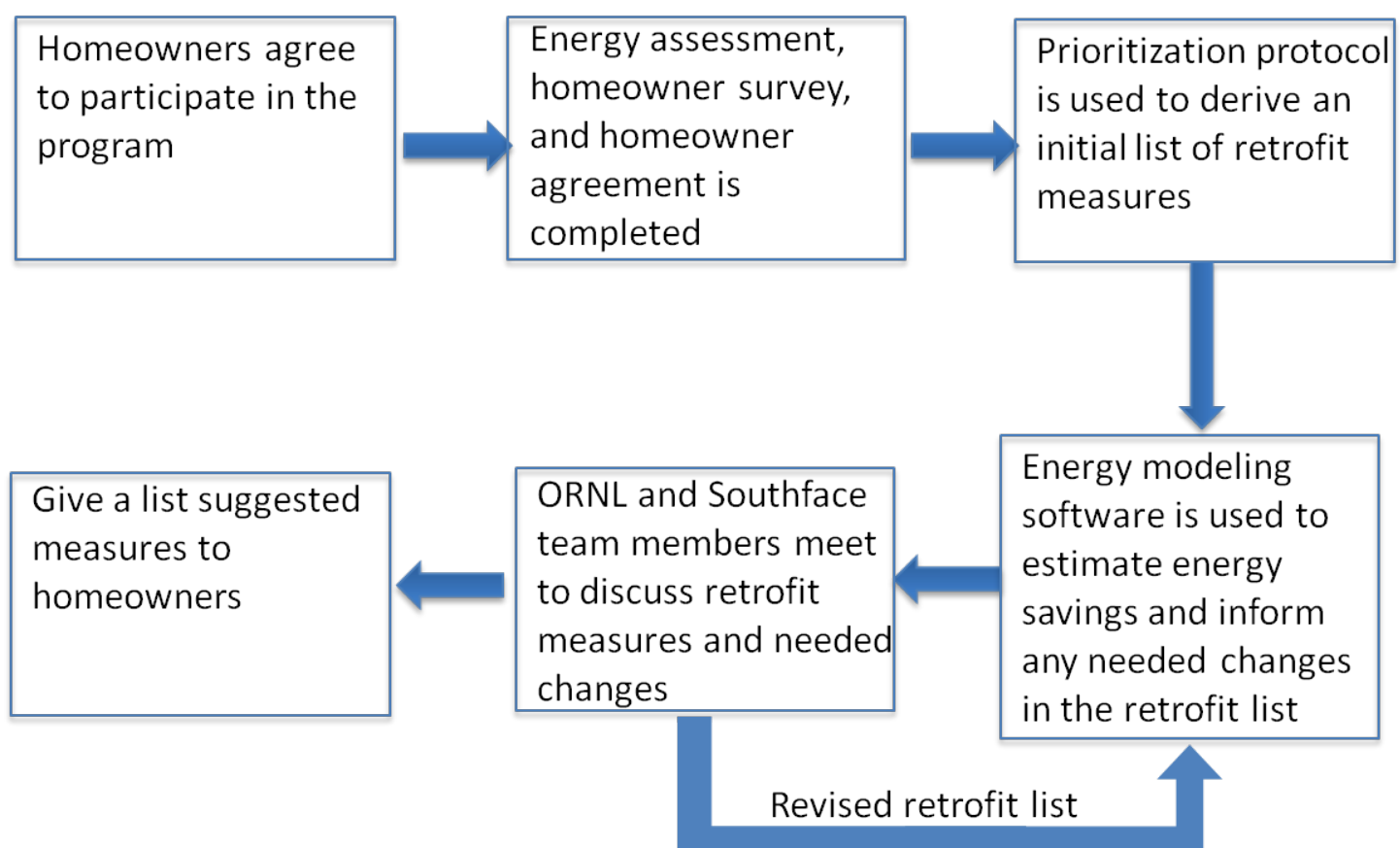

Figure 1. Approach used to determine retrofit measures

For this study, energy savings were estimated using the EnergyGauge energy simulation tool. Simulated energy consumption of the modeled home (pre-retrofit) was compared with utility bills $^{9}$ as well as modeled energy consumption using REM/Rate. Subsequently, the incremental impact of each energy saving measure was modeled and summed to determine the overall energy savings of the retrofit package. While 12 homes were initially identified as retrofit candidates, owners of only 9 of these homes decided to go forward with energy saving measures sufficient to generate expected energy savings of $30 \%$ or more.

After the retrofit, a test-out audit was performed to revise the analysis to reflect the actual postretrofit conditions. The audit included the building diagnostic metrics of air infiltration (from a Blower Door test) and duct leakage (from a Duct Blaster test).

While an initial building assessment was completed for each home prior to the retrofit, Blower Door tests were conducted at intervals during the retrofit to investigate the effectiveness of individual measures in reducing air infiltration. This was done when it was possible to coordinate with subcontractors. Conducting diagnostic Blower Door tests at various intervals can yield valuable information and insight for understanding the impact of individual measures and facilitating a more accurate prediction of energy savings. Subsequent Blower Door tests were based on the same volume as the test-in case unless the living area of the home was

\footnotetext{
${ }^{9}$ A formal calibration to weather normalized utility bills was not conducted. The comparison with utility bills was used to check general trends and large discrepancies.
} 
extended during the retrofit. For example, in cases where the attic was encapsulated, the living area was assumed to not change, even though the attic volume could be considered semiconditioned. The researchers acknowledge there are various ways of interpreting the volume that should be tested in Blower Door tests for infiltration. However, since the aim of multiple tests in this study was to determine the impact of various measures, it was necessary to keep volume constant as an experimental control. When applicable, Blower Door tests were conducted under different volume scenarios (e.g. attic volume and/or crawlspace volume included after encapsulation); however, the results are only included in this report when significant insight can be gained from their discussion.

\section{Energy Monitoring}

To better understand specific impacts of individual retrofit measures, six homes out of the nine were instrumented with a home energy data monitor - eMonitor ${ }^{\circledR}$ from Powerhouse Dynamics (research funding was not available to monitor all homes). In these homes, major energy consuming loads such as heating and cooling, the dryer, and the refrigerator were monitored, in addition to whole-house power. These monitors sample energy use at one minute intervals and log consumption data that can be downloaded from a central website. Because the monitors were installed prior to the retrofits, detailed pre- and post- retrofit submetered energy consumption for these homes will be available. This will be a valuable supplement to the preand post- retrofit analysis of energy bills.

\section{Industry Partners}

The success of this project can be attributed in part to the commitment that industry partners have shown. Research partners and their role include:

Agnes Scott College retrofitted 5 of their residential buildings as a part of this retrofit study. As a part of their campus sustainability efforts, Agnes Scott College was most supportive of extending their campus as a research extension of ORNL, while also showing a strong commitment to advancing residential retrofits.

Southern Company provided technical guidance and feedback on various retrofit measures, particularly with regard to HVAC systems. ORNL will work closely with Southern Company on evaluating and understanding the potential and realized savings of the high efficiency HVAC systems implemented in some of the home retrofits in this study.

A.O. Smith donated 2 direct vented, high efficiency gas water heaters and 1 heat pump water heater.

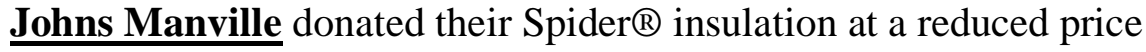

Renewal System Solutions was the retrofit contractor for 6 of the homes in this study. They interacted significantly with the ORNL/Southface team during the retrofit process. 


\section{New York}

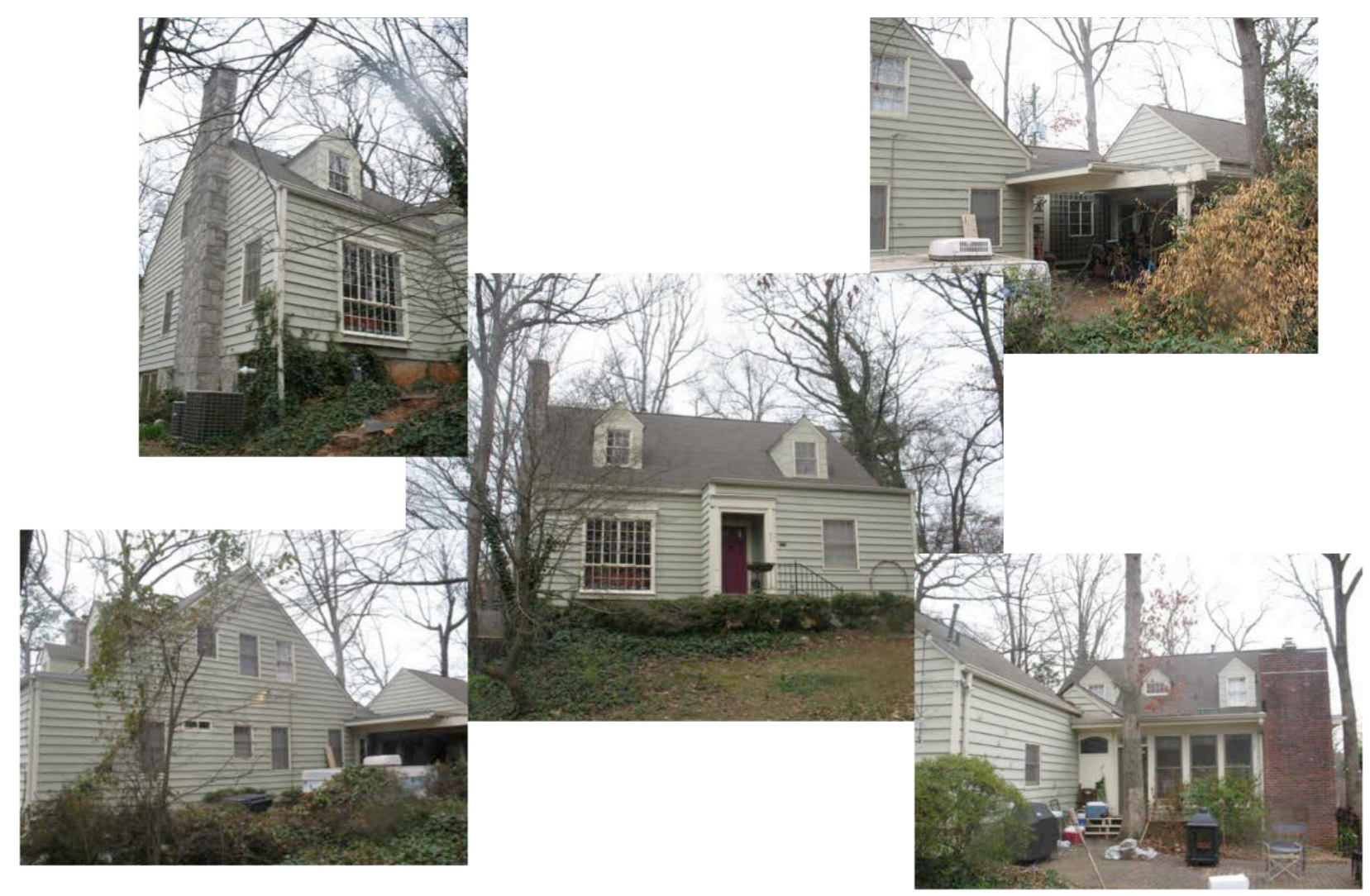

\section{New York Home Profile}

Originally built in the 1920s, New York is a two-story, single-family detached home with 3,050 $\mathrm{ft}^{2}$ of living area. The first floor has a living area of 2,230 $\mathrm{ft}^{2}$, while the second floor has $820 \mathrm{ft}^{2}$. New York is home to a family of two adults and three children. The home has five bedrooms and four bathrooms. New York has a traditional vented attic and a vented crawlspace. In later years, an addition was added to the home; however, the timing of the addition is unknown.

The family that lives in New York has rented the building for three years. Energy bills from February 2010 - January 2011 are shown in Figure 2. With an annual cost of \$3,614 and site energy use of $172 \mathrm{MMBtu}$, their energy costs are more than the average home of similar size in the southeast ${ }^{10}$. A portion of the above average energy consumption can be attributed to the fact that one of the family members has a home office. However, this is likely not as significant a factor as the lack of building envelope insulation and adequate air sealing (with both factors being indicative of the age of the home) and the building equipment. In addition to the above average energy consumption of New York, the family also stated that rooms in the home were not equally comfortable. Parts of the home, such as the living room and other rooms with more windows were often drafty.

\footnotetext{
${ }^{10}$ Per the 2010 Buildings Energy Data Book, energy consumption for the South Atlantic region is 47.4 kBtu per square foot. A similar home of this size would have an average annual energy consumption of $145 \mathrm{MMBtu}$.
} 


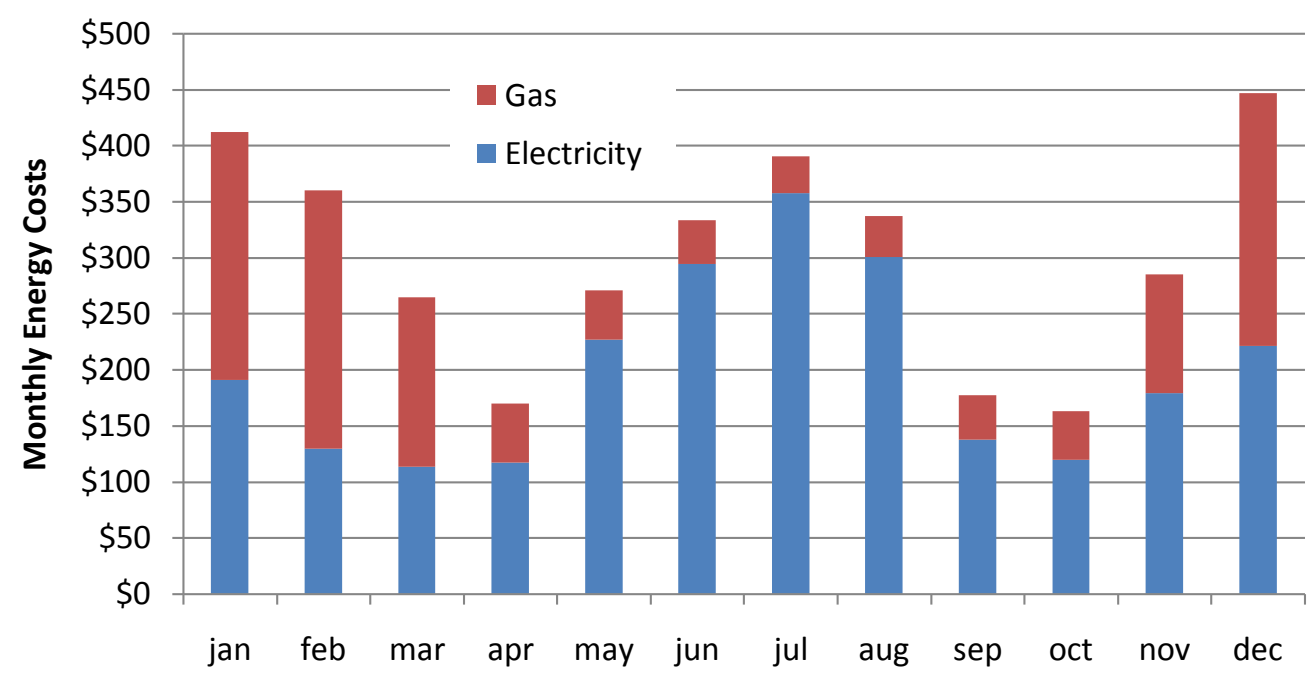

Figure 2. New York Monthly Energy Costs

In order to prevent even larger energy costs from space conditioning, the family relies on temperature setbacks as shown in Table 2.

Table 2. Temperature set points for New York

\begin{tabular}{|c|c|c|c|}
\hline \multicolumn{2}{|c|}{ Cooling } & \multicolumn{2}{c|}{ Heating } \\
\hline Time & Set point & Time & Set point \\
\hline $7: 00-8: 00$ & $\left({ }^{\circ} \mathrm{F}\right)$ & & 70 \\
\hline $8: 00-16: 00$ & 77 & $7: 00-9: 00$ & 64 \\
\hline $16: 00-22: 00$ & 82 & $9: 00-15: 00$ & 67 \\
\hline $22: 00-7: 00$ & 77 & $15: 00-22: 00$ & 60 \\
\hline
\end{tabular}

\section{New York Initial Characteristics Envelope Profile}

An illustration of the building envelope is shown in Figure 3. The building envelope is bounded by a framed floor above the vented crawlspace and an insulated ceiling plane above the first and second floors. The interior ceiling height for the first floor is 9 feet, while the average height of the second floor is 7 feet. The dark green colors in the figure represent the attic knee walls. As seen in the figure, there is significant attic exposure through knee walls, which had no insulation. 


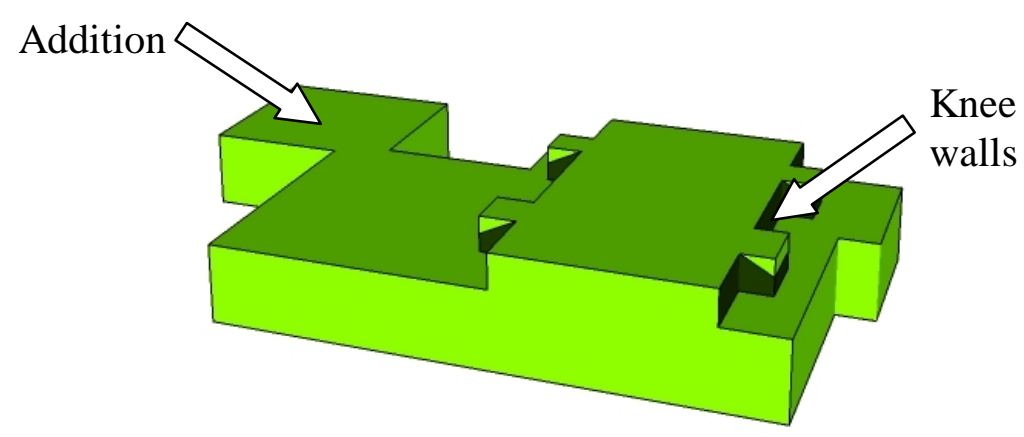

Figure 3. New York initial envelope profile

To aid in the building assessment, thermal infrared imaging was done. After an initial thermal scan and visual inspection by probing into a wall outlet of the main house, no presence of exterior wall cavity insulation was found. A thermal image of the main section of the home is shown in Figure 4. In contrast, the addition to the home, which was added in later years, was determined to have wall cavity insulation, as seen in the figure. R-11 fiberglass batts were assumed to be in the wall cavities.
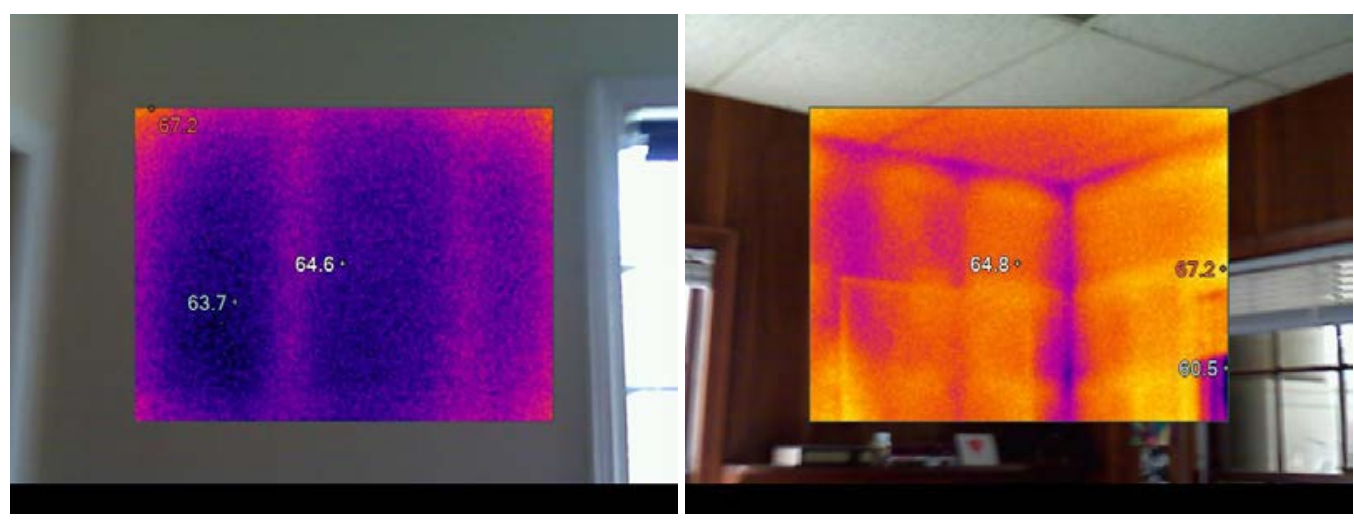

Figure 4. Thermal image of the exterior walls in the main section of the home (left image) and the addition (right image).

In the attic of the main section of the home, the ceiling has blown fiberglass insulation with an average coverage equivalent to approximately R-11 in half of the ceiling area. The other half did not have any insulation. In the addition, there is an average coverage of R-19 blown fiberglass. The attic access in the addition of the home has no insulation or weather-stripping. 
NEW YORK PRE-RETROFIT

\section{CHARACTERISTICS}

TYPE: Two-story, single-family

home

SIZE: $3,050 \mathrm{ft}^{2}$

Occupancy: Two adults and three children

\section{INITIAL ENVELOPE}

\section{PROFILE}

WALL INSULATION: NONE

BAND INSULATION: None

FOUNDATION SUBFLOOR

INSULATION: None

ATTIC INSULATION: R-11 (main) /

R-19 (addition)

KNEE WALL INSULATION: NONE

\section{INITIAL MECHANICAL}

\section{PROFILE}

FIRST FLOOR ZONE

Location: Unconditioned

crawlspace

Cooling: 10.4 SEER (electric)

Heating: 92 AFUE (natural gas)

\section{SECOND FLOOR ZONE}

Location: Vented attic

Cooling: 10 SEER (electric)

Heating: 80 AFUE (natural gas)

\section{ADDITION}

Cooling: 10.7 SEER (electric)

Heating: Thermador space

heaters

\section{WATER HEATER: 0.59 EF (gas)}

\section{INITIAL DIAGNOSTIC}

\section{RESULTS}

HERS: 165

HESCORE: 1

AIR INFILTRATION:

8,430 $\mathrm{CFM}_{50}\left(17 \mathrm{ACH}_{50}\right)$

DUCT LEAKAGE TO OUTSIDE:

$1^{\text {st }}$ floor: $785 \mathrm{CFM}_{25}$

$2^{\text {nd }}$ floor: $291 \mathrm{CFM}_{25}$

DUCT INSULATION: R-6

COMBUSTION SAFETY TEST:

Water heater failed spillage tests.
In the ceiling of the crawlspace (i.e. subfloor), there was no insulation. Likewise, there was no insulation on the foundation walls or band joist. While a vapor barrier on the ground in the crawlspace is needed and required per the Georgia Energy Code in Section 402.2.9 ${ }^{11}$, there was only limited coverage found. A consistent coverage on the ground is needed to prevent potential moisture pathways, and thereby reduce the risk for mold growth and wood rot. In the areas where the vapor barrier did exist, it was not taped and overlapped to the crawlspace walls and stem walls extending up at least 6" from the ground. Further visual inspection of the subfloor identified areas of air infiltration pathways into the conditioned space. These areas were most prevalent around plumbing and electrical penetrations.

The windows in the home are all single pane, with a mixture of metal and wood frames. The exterior cladding on the building was all wood siding. In many places, the siding needed to be replaced or repaired where evidence of rotting could be seen (Figure 5)
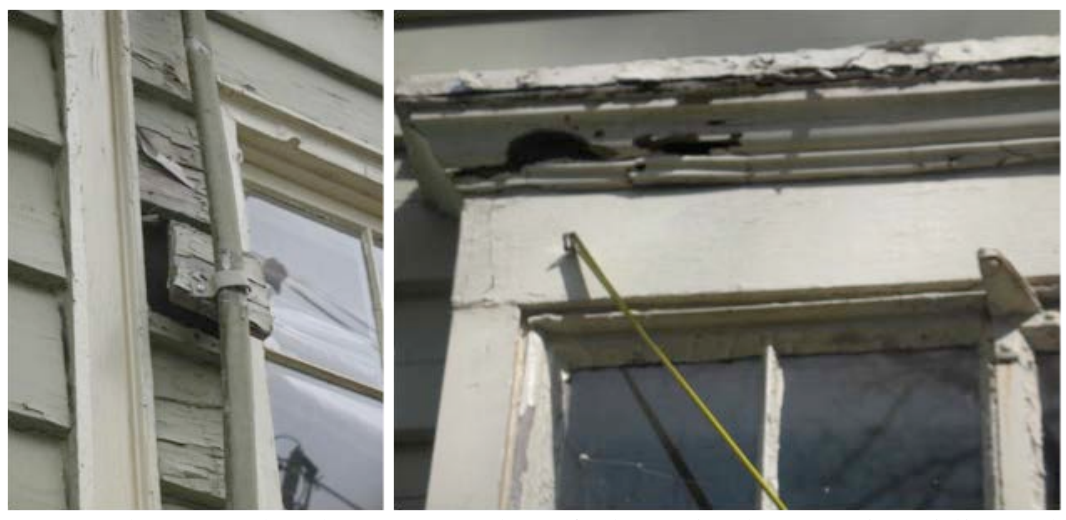

Figure 5. Photographs show examples of places in the exterior siding where rotting has occurred.

During the initial home energy assessment, a Blower Door test was conducted to evaluate the air infiltration. The total air leakage rate was $8,430 \mathrm{CFM}_{50}$. With a conditioned volume of $29,810 \mathrm{ft}^{3}$, the air exchange rate for New York was approximately $17 \mathrm{ACH}_{50}$.

\section{HVAC}

Conditioned air is provided in the main section of New York by two central HVAC systems. The first floor is served by a 3.5 ton capacity air conditioner, with an efficiency of 10.4 SEER located in the crawlspace. Also located in the crawlspace is the gas furnace for the first floor, which has a capacity of $100 \mathrm{kBtuh}$ and a rating of 92 AFUE. This sealedcombustion furnace was recently installed in the home. The second floor

${ }^{11}$ GA International Energy Conservation Code Supplements and Amendments 2011 
HVAC system is located in the attic. The air conditioner has a 2.5 ton capacity and a 10 SEER rating. The capacity of the gas furnace is $75 \mathrm{kBtuh}$, with an efficiency rating of 80 AFUE.

The ducts for first floor HVAC system were also located in the crawlspace. While the ducts were insulated with R-6 insulation, there was approximately 785 CFM $_{25}$ (35\% of the conditioned floor area) of duct leakage when measured using a Duct Blaster test protocol. There was 290 $\mathrm{CFM}_{25}$ of duct leakage for the second floor duct system.

Conditioned air is provided in the addition by a through-the-wall air conditioner (10 kBtuh capacity) and two $4 \mathrm{~kW}$ Thermador wall heaters. The air conditioner and wall heater are shown in Figure 6.

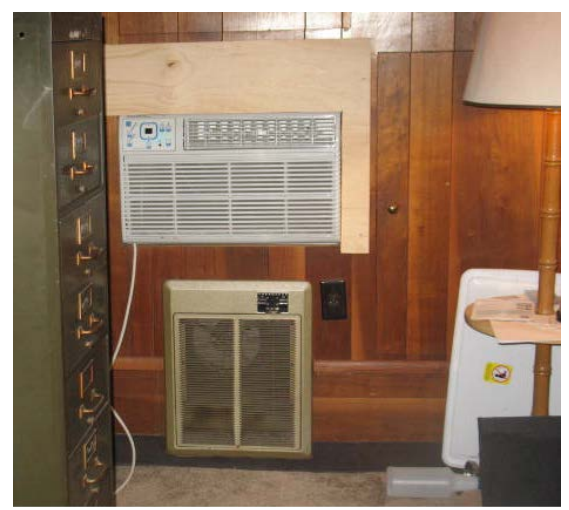

Figure 6. Photograph of the air conditioner and heater used in the addition.

In addition to the Thermador heaters used in the addition, a $1 \mathrm{~kW}$ dish heater was used in the main part of New York to provide space heating when needed.

\section{Lighting, Water Heating, Appliances}

The natural gas fueled water heater (located in the vented crawlspace) has a capacity of 50 gallons and an efficiency of $0.59 \mathrm{EF}$. All lighting in the home uses incandescent bulbs, and there are no ENERGY STAR appliances. The range and oven are electric.

\section{Health and Safety}

A thorough combustion safety test was performed on the water heater and furnace, because even though the units are considered to be outside of the envelope, there were major air leakage pathways that connect the area to the living space. Both gas furnaces passed all components of the combustion safety test: spillage, draft, and CO. The gas water heater similarly passed the draft and CO test but failed the spillage test under both natural and worst case conditions. 


\section{Retrofit Measures}

Using the prioritization protocol for this retrofit study, the following retrofit priorities were determined.

Table 3. New York priority list

\begin{tabular}{|l|l|c|}
\hline \multicolumn{1}{|c|}{ Improvement } & \multicolumn{1}{|c|}{ Existing condition } & Priority \\
\hline Air sealing & $\sim 1.0 \mathrm{ACH}_{\text {natural }}$ (2) & $\mathrm{A}$ \\
\hline Improve ducts & $24 \%$ duct leakage (upstairs) & $\mathrm{A}$ \\
\hline $\begin{array}{l}\text { Insulate ATTIC (attic floor air sealing } \\
\text { must precede insulation work) }\end{array}$ & R-0 - R-9 & $\mathrm{A}$ \\
\hline Insulate ATTIC KNEE WALLS & None & $\mathrm{A}$ \\
\hline Insulate FLOOR & None & $\mathrm{A}$ \\
\hline Insulate BASEMENT/CRAWLSPACE & None & $\mathrm{B}$ \\
\hline WALLS & None & $\mathrm{B}$ \\
\hline Insulate Walls & 80 AFUE (upstairs) & $\mathrm{C}$ \\
\hline Replace heating system & 92 AFUE (downstairs) & $\mathrm{C}$ \\
\hline Replace cooling system & 10 SEER (upstairs) & $\mathrm{D}$ \\
\hline Replace water heater & 10 SEER (downstairs) & $\mathrm{D}$ \\
\hline Insulate water heater and pipe & .59 gas & $\mathrm{D}$ \\
\hline Improve windows & Gas & $\mathrm{C}$ \\
\hline Improve windows & Wood single pane & $\mathrm{C}$ \\
\hline
\end{tabular}

Measures that received a priority of A or B from the prioritization protocol listed Table 3 were used as a basis for discussion with the homeowner and retrofit contractor on determining the final retrofit package. However, in this case, the building owner expressed an interest to have New York go through a deeper retrofit to serve as a model for others. With this in mind, a more extensive set of retrofit measures was included in the final package. Details are described in the following text.

\section{Envelope}

As can be seen in the retrofit priority list in Table 3, air sealing and attic insulation (attic floor and knee walls) were categorized as A priorities. As such, the ceiling plane would be one of the primary points of focus in completing these measures. However, the contractor suggested that it would be more difficult to adequately seal all of the ceiling penetrations and attic bypasses than it would be to encapsulate the attic with open-cell spray foam. Encapsulating the attic would also have the positive effect of bringing the second floor HVAC system into the semiconditioned volume where temperatures are more moderate and typically only vary approximately $5-15^{\circ} \mathrm{F}$ from the interior temperature set point. This is in contrast to conventional attics where the temperatures often exceed interior set points by $50^{\circ} \mathrm{F}$ or greater. In addition, the energy penalty of duct leakage is mitigated in encapsulated attics, since the "lost" conditioned air provides unintentional conditioning to the living space. Because visible roof

\footnotetext{
${ }^{12} \mathrm{ACH}_{\text {natural }}=\mathrm{ACH}_{50} / \mathrm{N}_{\text {corrected, }}$, where $\mathrm{N}_{\text {corrected }}$ is the height-corrected LBL "N-factor" (http://www.bpi.org/Web\%20Download/BPI\%20Standards/Building\%20Analyst\%20Professional_2-28-05nNCnewCO.pdf)
} 
damage was noted during the initial assessment, roof repairs were needed before encapsulating the attic as a retrofit measure. The homeowner decided to complete repairs prior to retrofit, as a part of maintenance for this home.

The attic was encapsulated by applying open-cell spray foam between the 2” x 6" rafters. The final layer of spray foam was applied in a manner that both filled the cavity between the rafters and left a continuous layer over the rafters eliminate thermal bridging, achieving an assembly insulation value of approximately R-21. A picture of the roofline after open-cell spray foam application is shown in Figure 7. The gable walls were insulated with 3.5” of open-cell spray foam (R-13). All vents in the attic were covered and subsequently sealed and insulated with an overlay of open-cell spray foam.

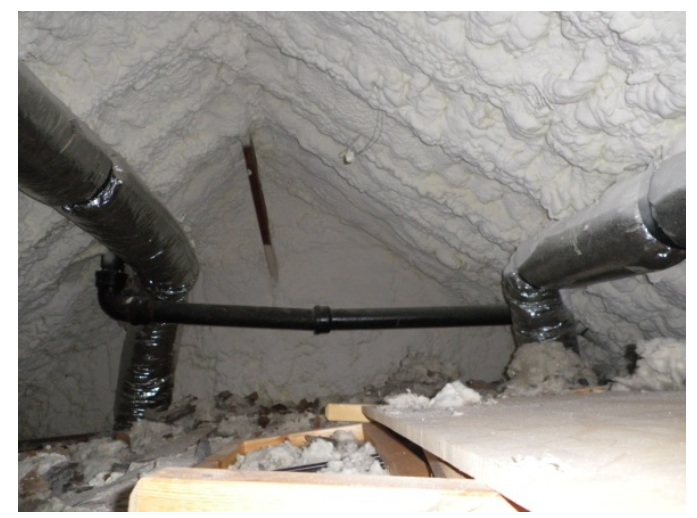

Figure 7. Open-cell spray foam on the roofline and gables.

As seen in the priority list in Table 3, adding insulation to either the crawlspace ceiling (i.e. subfloor) or the crawlspace walls was rated as a B priority. Since investigation of the exterior grading revealed no evidence of water management concerns, the building owner decided to encapsulate the crawlspace, and bring the crawlspace volume into the semi-conditioned volume, negating the need to insulate the subfloor. Because the HVAC system serving the first floor is located in the crawlspace, encapsulating the crawlspace would also result in significant HVAC savings since the system would now be located in the semi-conditioned volume. Finally, this measure would further address the significant air infiltration initially measured during the building test-in. In addition to blocking and sealing all vents into the crawlspace, the crawlspace was insulated with 2.5 " of open-cell spray foam at the band joist and 3.5” of closed-cell insulation on the foundation walls. The approximate insulation value of the foam applied on the band joist and foundation walls was R-9 and R-20, respectively. .

Prior to the foam application, a 12-mil vapor barrier, which addresses moisture management risks from the ground, was flash-coated to the walls with foam to ensure that at least 6" of the plastic adhered to the foundation walls. The closed-cell foam was then sprayed over the plastic. Per code, a 3" termite inspection strip was left at the top of the crawlspace walls for inspection purposes. The crawlspace door was insulated with rigid foam board and weather-stripped.

The new building envelope is illustrated in Figure 8. As shown in the figure, the attic and crawlspace are now considered part of the building envelope. 


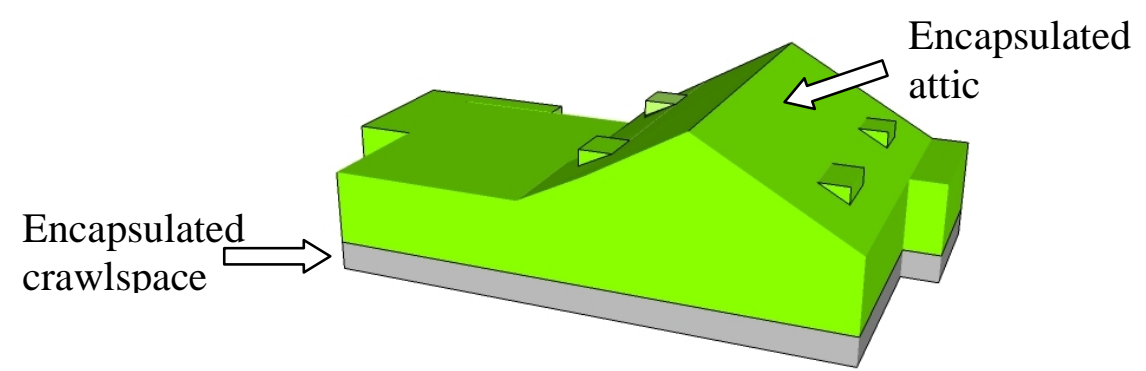

Figure 8. Illustration of building envelope after encapsulating the attic and crawlspace.

Even though the exterior walls were shown to not have cavity insulation (Figure 4), insulating the walls was prioritized as a $\mathrm{C}$ priority. This is because of the challenges and cost associated with insulating the wall cavities in an existing home. In retrofit applications, where the inside of the wall is not exposed, wall cavities are typically insulated by drilling a hole in each wall cavity and blowing loose-fill insulation such as cellulose or fiberglass into the wall. This "drill-andfill” method can be done either through the interior of the building or through the exterior. Completing the drill-and-fill approach from the interior requires the repair and painting of all interior walls once the insulation has been installed. On the other hand, when the drill-and-fill is done from the outside of the building, a section of the exterior cladding must be removed so that the hole can be drilled to provide wall cavity access and then replaced following insulation installation.

Insulating the wall cavity was also ruled out because of the possibility for unintended moisture management consequences following the addition of insulation. With no insulation in the wall cavities, the walls were able to "breathe" in the event that moisture/water enters the cavity. If the wall cavity is retrofitted with insulation without proper moisture control details, there is a potential for water induced damage such as mold and wood rot. Because New York was built in the 1920s, there were many unknowns with regard to the makeup of the exterior wall system, and it was not clear whether there was exterior sheathing on the building. It was also not clear whether there was a weather resistant barrier on the outside of the entire building envelope, and where present, its overall integrity of and effectiveness in mitigating bulk water transport into the wall cavity was not known. Because of these unknowns, insulating the wall cavities was initially not included in the retrofit package.

However, as shown in Figure 5, the siding on New York had significant damage and was in need of replacement. If the siding was replaced, filling the wall cavities with insulation would be more feasible. Once the old siding was removed, the extent of exterior sheathing would be clear. Where sheathing was present, the drill-and-fill approach could be more easily applied. In places where no sheathing was present, insulation could simply be blown into the cavities. Also, before the new siding would be installed, a housewrap could be applied on the building to guard against bulk moisture intrusion in the wall cavity. Given the need for siding replacement, coupled with the energy benefit that adding insulation to wall cavities would bring, the building owner decided 
to go forward with replacing the siding and adding wall cavity insulation. Doing so would mean that New York would be a deeper energy retrofit than others in the study since all six sides of the building envelope were addressed: the top of the building envelope (i.e. attic encapsulation), the bottom of the building envelope (i.e. crawlspace encapsulation), and the walls (i.e. wall cavity insulation).

Because the paint used on the existing siding contained lead, standard procedures for lead abatement were followed when the siding was removed. While removing the siding, the contractor discovered additional wood rot and termite damage along the bottom plates of the addition to the house. These were repaired prior to insulation being blown into cavities and the new siding installed.

After the siding was removed, the existence of exterior sheathing, or lack thereof, was evident. The original part of New York which was built in the 1920s ("main section”) had diagonal plank sheathing, while the addition had no exterior sheathing. Even though the addition originally had R-13 batt insulation in the cavities, there were many voids in the cavities. Therefore, the batts were removed so that fiberglass insulation (Spider® by Johns Manville) could be blown in the cavities of both the main section of New York as well as the addition. However, after the batts were removed in the addition, a plastic vapor barrier was found attached to the inside of the walls. In Climate Zone 3, a vapor barrier should not be applied on the interior of the wall cavity because condensation can develop behind the walls, which could result in compromised durability and wood rot. Fortunately, one of the researchers on this project was on site to remove the plastic film prior to the insulation being blown in the cavity.

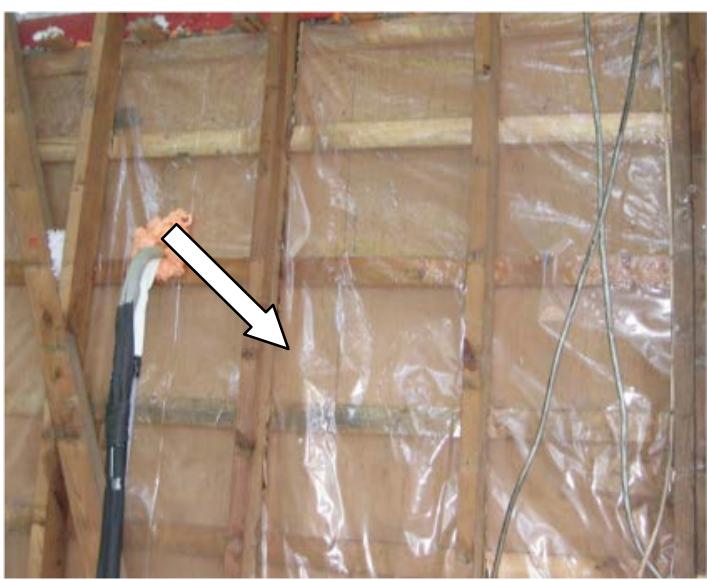

Figure 9. Wall cavity in New York where an interior vapor barrier is present. 
When installed in 2x4 wall cavities, the fiberglass Spider insulation has an R-value of R-15. Figure 10 shows the insulation being blown into the wall cavities in the addition.
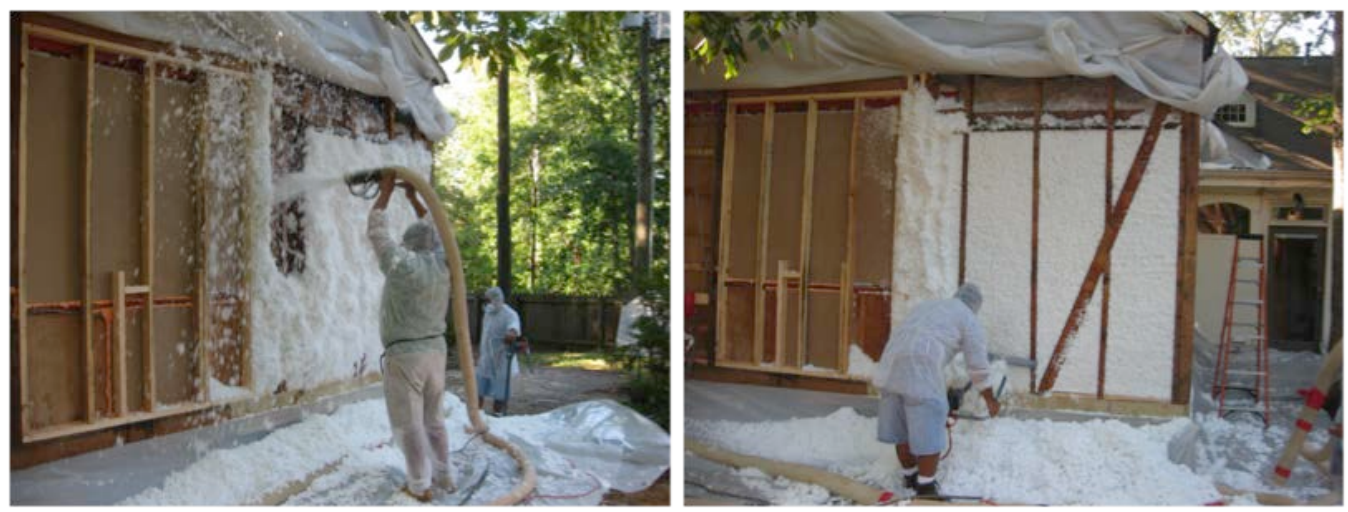

Figure 10. Spider insulation blown into the exposed cavities.

In the main section of the home, the insulation was blown into the cavities through two holes drilled in each cavity - one at the top, and one at the bottom. The installer blew the fiberglass in from the top to let the insulation sink to the bottom. The installer then "dense packed" the insulation in the wall by blowing fiberglass into the bottom hole in the cavity.
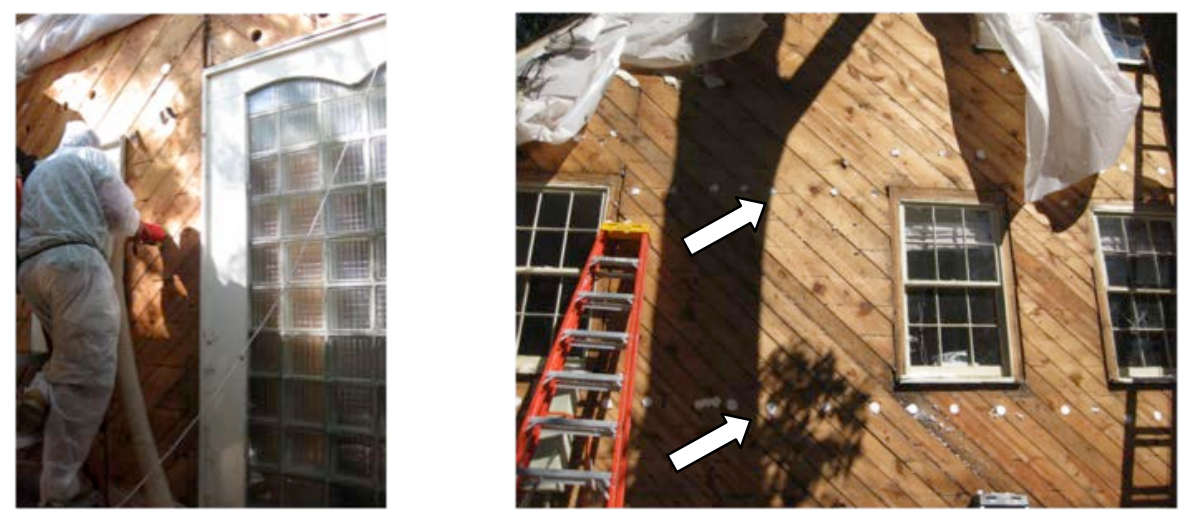

Figure 11. Photographs of the "drill-and-fill" installation of fiberglass insulation into the cavity walls. Image on the left shows the installer blowing fiberglass into the cavity. Two holes in each cavity can be seen in the image on the right.

The left window in the front of the home was replaced with an ENERGY STAR double-pane wood window. The back window in the addition was removed. However, in this case, it was not replaced.

Additional air sealing measures included capping off and adding a chimney balloon in each of the two chimneys.

\section{HVAC}

The air conditioning unit which serves the first floor was replaced with a 3 ton capacity air conditioner with an efficiency rating of 14.5 SEER. The natural gas furnace was not replaced. 
Since the crawlspace has been insulated and sealed (i.e. encapsulated), the system is now considered to be inside of the building envelope.

Both the air conditioner and the natural gas furnace that serves the second floor were replaced. A new 2.5 ton, 14.5 SEER air conditioner was added, along with a furnace with a $70 \mathrm{kBtuh}$ capacity and an efficiency rating of 95 AFUE. Similar to the HVAC system in the crawlspace, the system is now considered to be inside of the building envelope, since the attic was encapsulated.

To replace the resistance heaters and the through-the-wall air conditioner in the addition, a ductless mini-split heat pump system with an indoor unit capacity of 1 ton and an efficiency rating of 19.2 SEER and 10.1 HSPF was added. The outdoor unit has a rated capacity of 1.5 ton unit. The refrigerant line comes from the outside into the back of the addition as shown in Figure 12.

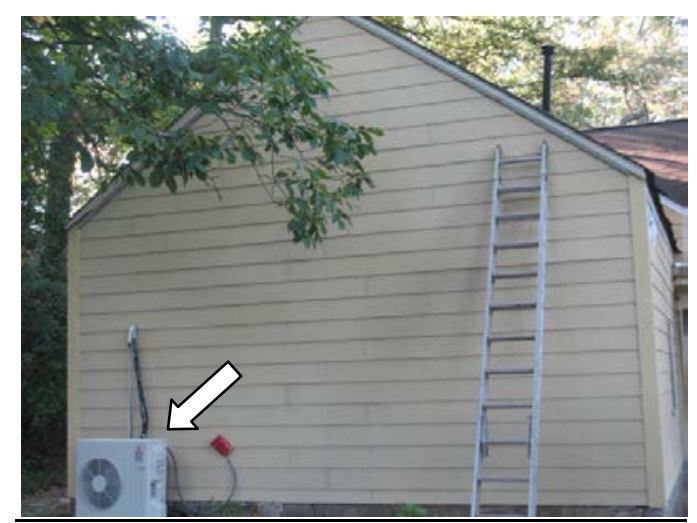

Figure 12. Photograph of the rear view of the addition. The mini-split outdoor unit is highlighted in the image by the arrow.

\section{Lighting, Water Heating, Appliances}

The water heater was replaced with an 80 gallon A.O. Smith heat pump water heater. The efficiency rating of the unit is $2.4 \mathrm{EF}$. No lighting or appliance upgrades were made.

\section{Health and Safety}

In this retrofit, the atmospherically vented gas furnace was replaced with a sealed combustion gas furnace, and the gas fired water heater was replaced with a heat pump water heater.

Therefore, combustion safety risks were mitigated.

\section{Simulated Energy Savings}

Table 4 shows the simulated energy savings from the implemented retrofit measures. The largest portion of energy savings are attributed to the envelope improvements made in the home. This is because the envelope improvements reduced building infiltration and the thermal load from the entire building envelope (i.e. attic, crawlspace, and walls). Additionally, since the attic and crawlspace were encapsulated, the thermal environments for both HVAC systems were tempered, which also resulted in expected energy savings that are attributed to the envelope improvements. In total, there is an estimated $42 \%$ reduction in source energy consumption and $56 \%$ reduction in site energy consumption. 
Table 4. New York recommended package with simulated energy savings from EnergyGauge

\begin{tabular}{|l|r|r|r|r|}
\hline & \multicolumn{1}{|c|}{$\begin{array}{c}\text { Predicted } \\
\text { Site } \\
\text { Energy } \\
\text { (MMBtu) }\end{array}$} & $\begin{array}{c}\text { Predicted } \\
\text { Source } \\
\text { Energy } \\
\text { (MMBtu) }\end{array}$ & $\begin{array}{c}\text { Site } \\
\text { Energy Savings } \\
\text { (\% per measure) }\end{array}$ & $\begin{array}{c}\text { Source } \\
\text { Energy Savings } \\
\text { (\% per measure) }\end{array}$ \\
\hline New York & 214 & 369 & & \\
\hline $\begin{array}{l}\text { + Envelope } \\
\text { Improvements }\end{array}$ & 137 & 262 & $36 \%$ & $29 \%$ \\
\hline $\begin{array}{l}\text { ++ HVAC System } \\
\text { Improvements }\end{array}$ & 112 & 219 & $12 \%$ & $12 \%$ \\
\hline $\begin{array}{l}\text { +++ Water Heater } \\
\text { Improvements }\end{array}$ & 95 & 213 & $8 \%$ & $2 \%$ \\
\hline $\begin{array}{l}\text { Total Retrofit } \\
\text { Investment }\end{array}$ & & & $56 \%$ & $42 \%$ \\
\hline
\end{tabular}

As can be seen in Figure 13, the energy savings in the primary building loads are significant. The heating and cooling load energy savings are $67 \%$ and $62 \%$, respectively, while the water heating savings are more than $20 \%$.

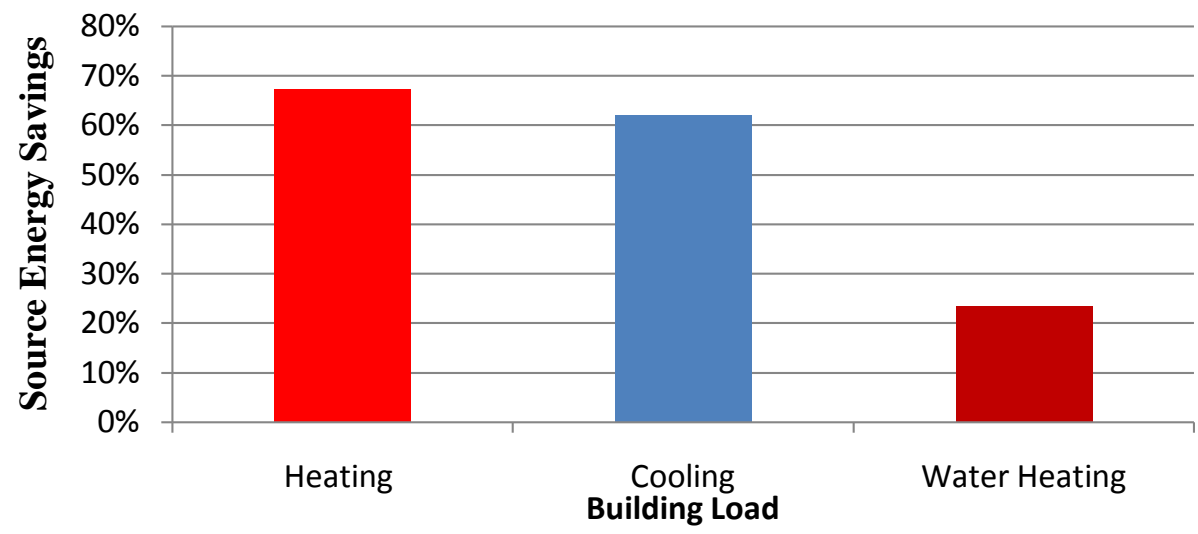

Figure 13. Simulated Energy Savings from Heating and Cooling Loads

\section{Diagnostics and Test Out}

When scheduling with subcontractors permitted, Blower Door tests were done at intervals to investigate the effectiveness of individual retrofit measures. The test results are shown in Table 5 , in the order in which the tests were done. Conducting successive diagnostic Blower Door tests at various intervals can be informative and insightful with regard to understanding the impact of specific measures to facilitate a more accurate prediction of energy savings. For each case, the calculated $\mathrm{ACH}_{50}$ is based on the volume of the living space only, even though the volume of the encapsulated attic and crawlspace can be considered as part of the conditioned volume.

Including the additional conditioned volumes of the attic and the crawlspace in determining air changes per hour can cause the $\mathrm{ACH}_{50}$ to decrease in a manner inconsistent with the infiltration improvements. Since infiltration improvements are the basis for this comparison, only the original living area volume is included. 
For example, as seen in the table, encapsulating the attic resulted in a $31 \%$ reduction in air infiltration. Similarly, insulating the crawlspace band, while also sealing all vents reduced the infiltration by approximately $18 \%$. In total, the infiltration was reduced by approximately $44 \%$. However, it is noteworthy that air infiltration increased after the wall cavities were insulated the last step after finishing the other retrofit measures- in contrast to the expectation that infiltration would decrease. The reason for this observation is not obvious. Possible causes include:

- The housewrap applied during the retrofit does not limit air infiltration as much as the felt paper did prior to the retrofit.

- A measurement error occurred while determining the air infiltration prior to insulating the wall cavities. The infiltration after the wall cavities were insulated was verified by measuring on two different occasions.

- An additional air bypass was introduced in the last phase of the retrofit.

Table 5. Pre-retrofit and post-retrofit air infiltration diagnostics

\begin{tabular}{|l|c|c|}
\hline Retrofit Measure Tested & $\begin{array}{c}\text { Blower Door Test Result } \\
\left.\text { (CFM }_{\mathbf{5 0}} \mathbf{A C H}_{\mathbf{5 0}}\right)\end{array}$ & Percent Reduction $^{\mathbf{1 3}}$ \\
\hline Initial & $8,430 / 17$ & $18 \%$ \\
\hline $\begin{array}{l}\text { Crawlspace band insulated with } \\
\text { open-cell foam (vents blocked } \\
\text { and sealed) }\end{array}$ & $6,950 / 14$ & $31 \%$ \\
\hline $\begin{array}{l}\text { Attic encapsulated with open- } \\
\text { cell foam }\end{array}$ & $4,770 / 9.6$ & $10 \%$ \\
\hline $\begin{array}{l}\text { Foundation wall insulated with } \\
\text { closed-cell foam }\end{array}$ & $4,310 / 8.7$ & \\
\hline $\begin{array}{l}\text { Wall cavities insulated; one } \\
\text { window removed; one window } \\
\text { replaced; through-the-wall air } \\
\text { conditioner removed }\end{array}$ & $4680 / 9.4$ & $-9 \%$ \\
\hline Final & $4,680 / 8.7$ & $44 \%$ \\
\hline
\end{tabular}

When an attic is encapsulated, the retrofit measures are often described as insulating the roofline and sealing the attic. However, in most home energy retrofits, terminology such as "sealing the attic" should be used and understood with care. It is not clear, and probably not likely, that spray foam installers are able to perfectly seal all attics that are "sealed". Since partially sealed attics can lead to moisture penetration into the attic volume increasing the potential for condensation, wood rot, and mold, the level of attic sealing resulting from attic encapsulation is worth

\footnotetext{
${ }^{13}$ Percent reduction is determined by evaluating the $\mathrm{CFM}_{50}$ reduction for each of the retrofit measures as a ratio of the total building infiltration.
} 
distinction. Because of the questions the researchers in this study had concerning the level of "attic sealing” that occurs in retrofits, Blower Door tests were conducted with the attic access closed and with the attic access open before the final test-out (also before the wall cavities were filled with fiberglass insulation). When the attic access is closed, the attic is only partially connected to the house through leakage pathways in the ceiling and in ducts located in the attic. However, in the latter case, when the attic access is open, the attic volume is better connected to the house such that additional building infiltration can be likely attributed to the attic volume. If the attic is sealed from the exterior, there should be little to no additional infiltration when the attic access is opened. In this case, with the attic access closed, the Blower Door test yielded an infiltration of 4,680 $\mathrm{CFM}_{50}$ (Table 5). In contrast, with the attic access open, the Blower Door test yielded an infiltration of 4,715 $\mathrm{CFM}_{50}$, an increase of $35 \mathrm{CFM}_{50}$. With such a small increase in infiltration it is not possible to make a reasonable conclusion in regard to the attic infiltration. Dataloggers will be placed in the attic so that moisture levels and temperatures can be monitored and the impact of the attic infiltration can be evaluated in 2011-2012.

The impact of replacing the ducts is shown in Table 6. Initially, the duct leakages as a ratio of the conditioned area served were $35 \%$ and $40 \%$ for the first and second floor systems, respectively. However, after both duct systems were either replaced or repaired and sealed, the second floor ducts had no leakage, while the first floor leakage was reduced by $66 \%$. The remaining duct leakage in the first floor system is likely attributed to registers and duct boots that are located in interior walls (Figure 14), which are difficult to adequately seal.

Table 6. Duct Blaster test results for New York house - duct leakage to outside measured as air flow at 25 $\mathrm{Pa}\left(\mathrm{CFM}_{25}\right)$ and normalized as a percentage $\left(\mathrm{CFM}_{25} /\right.$ conditioned area $\left.\left(\mathrm{ft}^{2}\right)\right)$

\begin{tabular}{|c|c|c|c|c|}
\hline & \multicolumn{2}{|c|}{$\begin{array}{c}\text { System 1* } \\
\text { (first floor) }\end{array}$} & \multicolumn{2}{c|}{$\begin{array}{c}\text { System 2** } \\
\text { (second floor) }\end{array}$} \\
\hline & CFM $_{25}$ & \% Leakage to Outside & CFM $_{25}$ & \% Leakage to Outside \\
\hline Initial & 785 & $35 \%$ & 291 & $40 \%$ \\
\hline Post & 267 & $12 \%$ & 0 & $0 \%$ \\
\hline \% Reduction & $66 \%$ & $66 \%$ & $100 \%$ & $100 \%$ \\
\hline
\end{tabular}

* The conditioned area is equal to $2,230 \mathrm{ft}^{2}$.

** The conditioned area is equal to $820 \mathrm{ft}^{2}$.

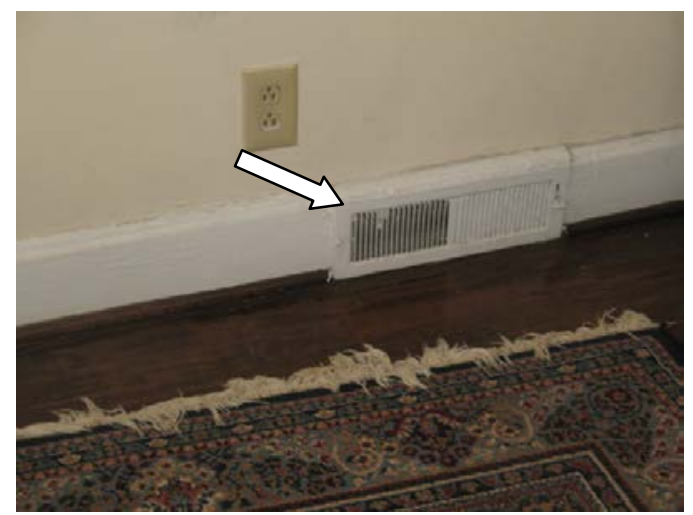

Figure 14. Duct register located in an interior wall. 
Overall the final HERS index improved from 165 to 77, which reflects the significant energy savings that are predicted for this retrofit. In FY12, whole-house energy consumption, along with the contribution of major loads such as the air conditioner, will be submetered by an eMonitor energy logger. Additionally, utility bills will continue to be collected for comparison with pre-retrofit utility bills.

\section{New York Costs and Scope of Work}

The retrofit measures described in this report were completed in September 2011, at a total cost of about $\$ 41,669$. If the cost of siding removal and replacement are included the total cost of the renovation is $\$ 56,294$.

Table 7 provides a summary of the final scope of work and breakdown of the costs.

Table 7. New York final scope of work and costs.

\begin{tabular}{|c|c|c|c|}
\hline Home Characteristics & Existing Conditions & Measures & Proposed Costs \\
\hline \multirow{3}{*}{ Exterior Walls } & \multirow{3}{*}{ R-0 in wall cavities } & $\begin{array}{l}\text { Siding removed and } \\
\text { replaced }\end{array}$ & \multirow{3}{*}{$\begin{array}{c}\$ 17,475(14,625 \text { for } \\
\text { siding removal and } \\
\text { replacement, } 2,850 \\
\text { for insulation } \\
\text { installation) }\end{array}$} \\
\hline & & $\begin{array}{l}\text { R-15 added to wall } \\
\text { cavities }\end{array}$ & \\
\hline & & Housewrap installed & \\
\hline $\begin{array}{c}\text { Attic/ } \\
\text { Knee walls }\end{array}$ & $\begin{array}{l}\mathrm{R}-11 / \\
\mathrm{R}-0\end{array}$ & $\begin{array}{l}\text { Attic encapsulated with } \\
\text { R-21 open-cell spray } \\
\text { foam on roofline }\end{array}$ & $\$ 7,520$ \\
\hline \multirow{3}{*}{ Foundation } & \multirow{3}{*}{$\begin{array}{l}\text { R-0 between subfloor } \\
\text { joists / No insulation } \\
\text { on the foundation } \\
\text { walls }\end{array}$} & $\begin{array}{l}\text { R-13 (closed-cell foam } \\
\text { on walls) }\end{array}$ & \multirow{3}{*}{$\$ 4,279$} \\
\hline & & $\begin{array}{l}\text { R-11 (open-cell foam on } \\
\text { band) }\end{array}$ & \\
\hline & & New vapor barrier & \\
\hline \multirow{3}{*}{ Cooling } & \multirow{3}{*}{$\begin{array}{l}3.5 \text { ton, } 10 \text { SEER } \\
\text { (1 } 1^{\text {st }} \text { floor) } \\
2.5 \text { ton, } 10 \text { SEER } \\
\quad\left(2^{\text {nd }} \text { floor }\right) \\
\text { Through-the-wall } \\
\text { room air conditioner } \\
\text { (addition) }\end{array}$} & $\begin{array}{l}\text { 3- ton, 14.5 SEER } \\
\text { (1st floor) }\end{array}$ & \multirow{6}{*}{$\$ 19,420$} \\
\hline & & $\begin{array}{l}2.5 \text { ton, 14.5 SEER } \\
\text { (2nd floor) }\end{array}$ & \\
\hline & & $\begin{array}{l}\text { 19.2 SEER mini-split } \\
\text { heat pump }\end{array}$ & \\
\hline \multirow{3}{*}{ Heating } & $\begin{array}{l}100 \text { kBtuh } 92 \text { AFUE } \\
\left(1^{\text {st }} \text { floor }\right)\end{array}$ & $\begin{array}{c}\mathrm{N} / \mathrm{A} \\
\left(1^{\text {st }} \text { floor }\right) \\
\end{array}$ & \\
\hline & $\begin{array}{l}75 \text { kBtuh } 80 \text { AFUE } \\
\left(2^{\text {nd }} \text { floor }\right)\end{array}$ & $\begin{array}{l}70 \text { kBtuh 95 AFUE } \\
\text { (2nd floor })\end{array}$ & \\
\hline & $\begin{array}{c}4 \mathrm{~kW} \text { Thermador } \\
\text { space heater }\end{array}$ & $\begin{array}{l}10.1 \text { HSPF mini-split } \\
\text { heat pump }\end{array}$ & \\
\hline DHW & .59 EF natural gas & $\begin{array}{l}\text { 2.4 EF electric heat } \\
\text { pump water heater }\end{array}$ & $\begin{array}{l}\text { Donated by A.O. } \\
\text { Smith (MSRP = } \\
\$ 2,200) ; \$ 1,260 \text { for } \\
\text { installation }\end{array}$ \\
\hline
\end{tabular}




\begin{tabular}{|c|c|c|c|}
\hline Home Characteristics & Existing Conditions & Measures & Proposed Costs \\
\hline Windows & $\begin{array}{c}\text { Single-pane wood/ } \\
\text { single-pane metal }\end{array}$ & $\begin{array}{c}\text { Double-pane ENERGY } \\
\text { STAR for front left } \\
\text { window }\end{array}$ & $\$ 4,140$ \\
\hline
\end{tabular}

* Exterior wall costs include the cost of replacing the siding and the cost of filling the wall cavities with insulation.

** HVAC costs include repair/replacement of the duct systems 


\section{Michigan}

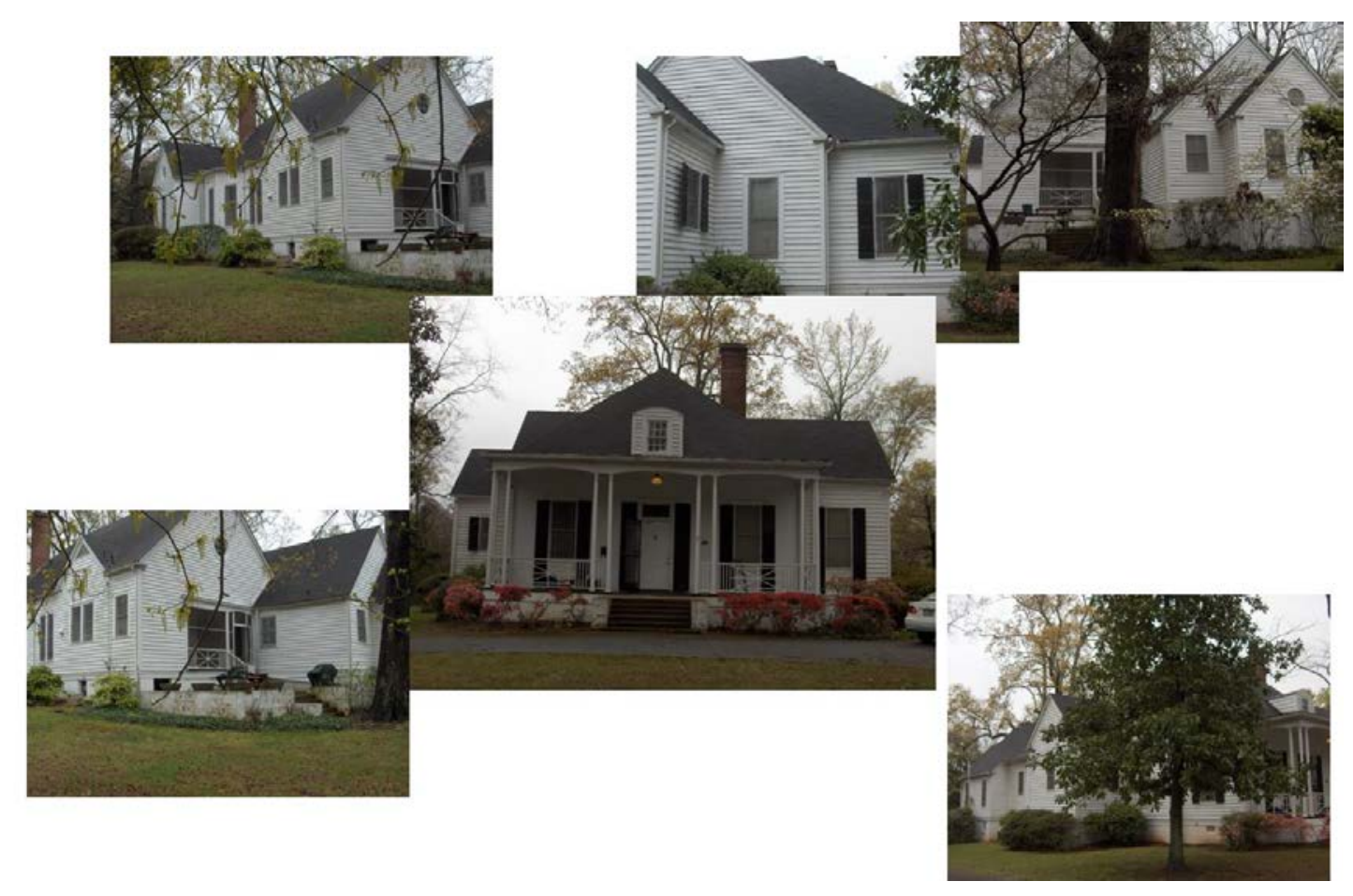

\section{Michigan Home Profile}

Originally built in the 1920s, Michigan is a one story, single-family detached home with 3,380 $\mathrm{ft}^{2}$ of living area. There are three bedrooms and two bathrooms. One of the bedrooms is a master suite with an area of $730 \mathrm{ft}^{2}$. Michigan has a traditional vented attic and a vented crawlspace. A family of two adults and one child has rented this home for more than three years.

The family's average energy costs from 2009 through 2010 are shown in Figure 15. With a total annual cost of \$3,940 (212 MMBtu of site energy), the family’s energy costs are higher than the average annual site energy consumption for a typical home in the southeast of this size (141 $\mathrm{MMBtu}^{14}$ ). However, since the family in Michigan considers energy conservation as a priority, their energy costs are tempered with respect to their potential costs. As energy conservation measures, they set their thermostat set points to $78^{\circ} \mathrm{F}$ in the summer. In the winter they set the thermostat to $58^{\circ} \mathrm{F}$ at night and a typical range of $62-68^{\circ} \mathrm{F}$ in the day. By contrast, the operating conditions for the Building America House Simulation Protocol are $76^{\circ} \mathrm{F}$ for the cooling season and $71^{\circ} \mathrm{F}$ for the heating season. Therefore, the building heating and cooling loads are not as high as would otherwise be if not for energy conservation behaviors.

\footnotetext{
${ }^{14}$ Per the 2010 Buildings Energy Data Book, energy consumption for the South Atlantic region is 47.4 kBtu per square foot.
} 


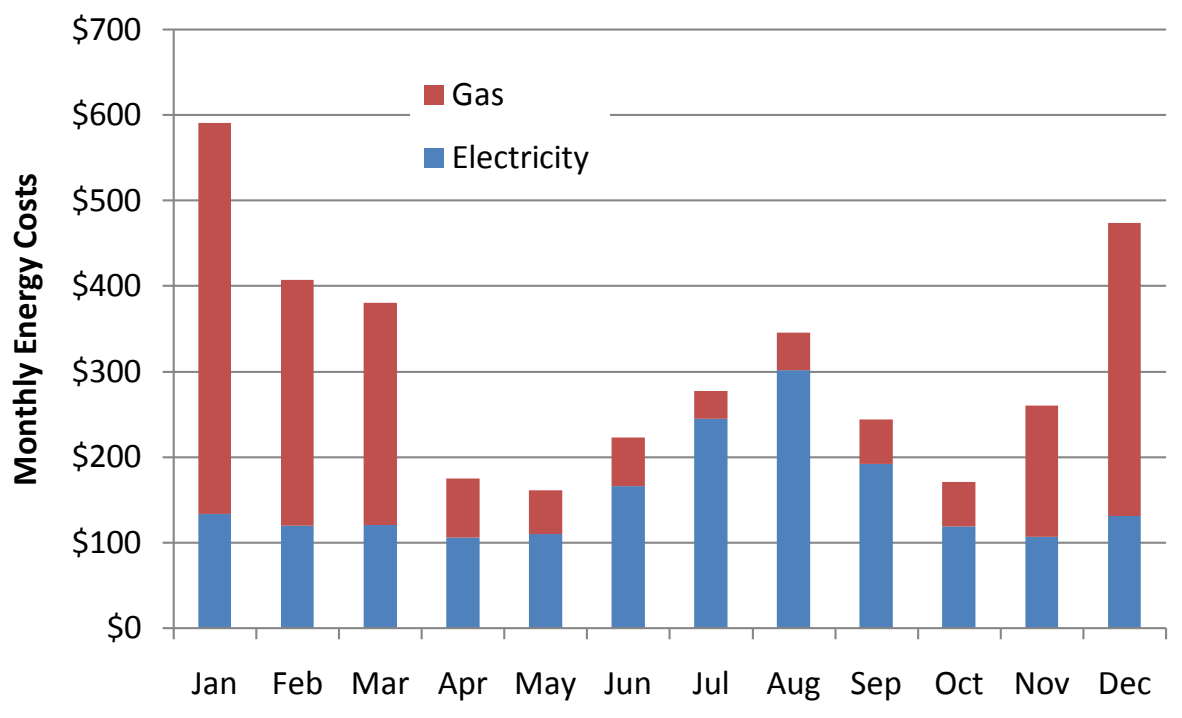

Figure 15. Michigan monthly energy costs

\section{Michigan Initial Characteristics}

\section{Envelope Profile}

Shown in Figure 16 is an illustration of the initial envelope profile for Michigan. There are high ceilings throughout the main section and master suite with heights of $12 \mathrm{ft}$ and $10 \mathrm{ft}$, respectively. The envelope is bounded by an insulated framed floor above the vented crawlspace and an insulated ceiling plane above the first floor. Represented in Figure 16, by the dark green colors are attic knee walls that result from the varied ceiling heights. There were R-13 batts (rock wool) in most of these knee walls, as shown in Figure 17.

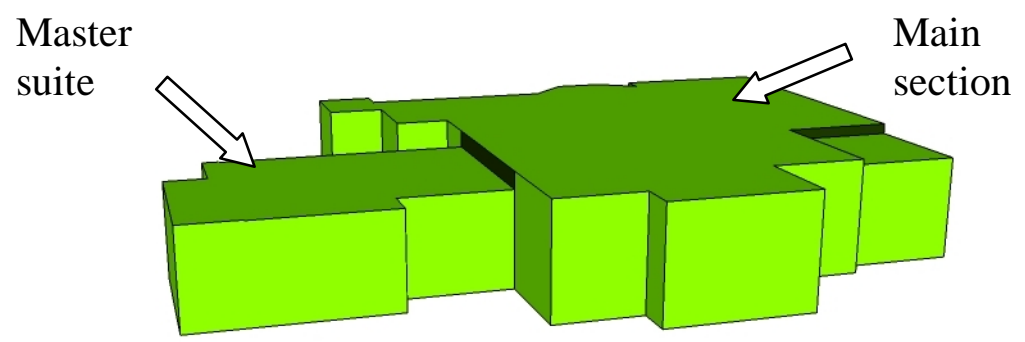

Figure 16. Illustration of Michigan's initial building envelope profile.

In addition to the knee walls in Michigan, there were also attic bypasses into interior wall cavities. These types of bypasses were present around the chimney and in chases created by built-in features such as bookcases and cabinets. Shown in Figure 18 is an example of the attic bypasses found in Michigan. 


\section{MICHIGAN PRE-}

RETROFIT

CHARACTERISTICS

TYPE: Two-story, single-family home

SIZE: $3,380 \mathrm{ft}^{2}$

Occupancy: Two adults, one child

\section{INITIAL ENVELOPE}

\section{PROFILE}

WALL INSULATION: NONE BAND INSULATION: None ATTIC INSULATION: R-11

KNEEWALL INSULATION: R-13

\section{INITIAL MECHANICAL}

\section{PROFILE}

\section{MAIN ZONE}

Location: Unconditioned basement

Cooling: 9 SEER (electric) Heating: 80 AFUE (natural gas)

\section{MASTER SUITE ZONE}

Location: Vented attic

Cooling: 10 SEER (electric)

Heating: 91 AFUE (natural gas)

WATER HEATERS: 0.57 EF, $0.58 \mathrm{EF}$

\section{INITIAL DiAgNOSTIC}

\section{RESULTS}

HERS: 167

HESCORE: 1

AIR INFILTRATION:

9.840 $\mathrm{CFM}_{50}\left(14.8 \mathrm{ACH}_{50}\right)$ DUCT LEAKAGE TO OUTSIDE: Main: too high to measure Master suite: too high to measure

DUCT INSULATION: R-6

COMBUSTION SAFETY TEST: All the units passed.

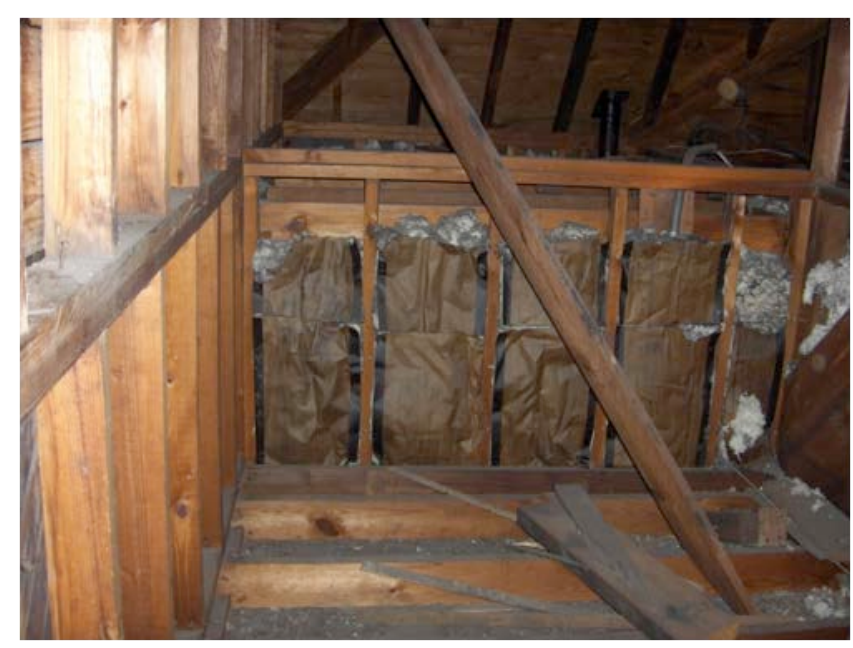

Figure 17. Photograph of knee walls in Michigan

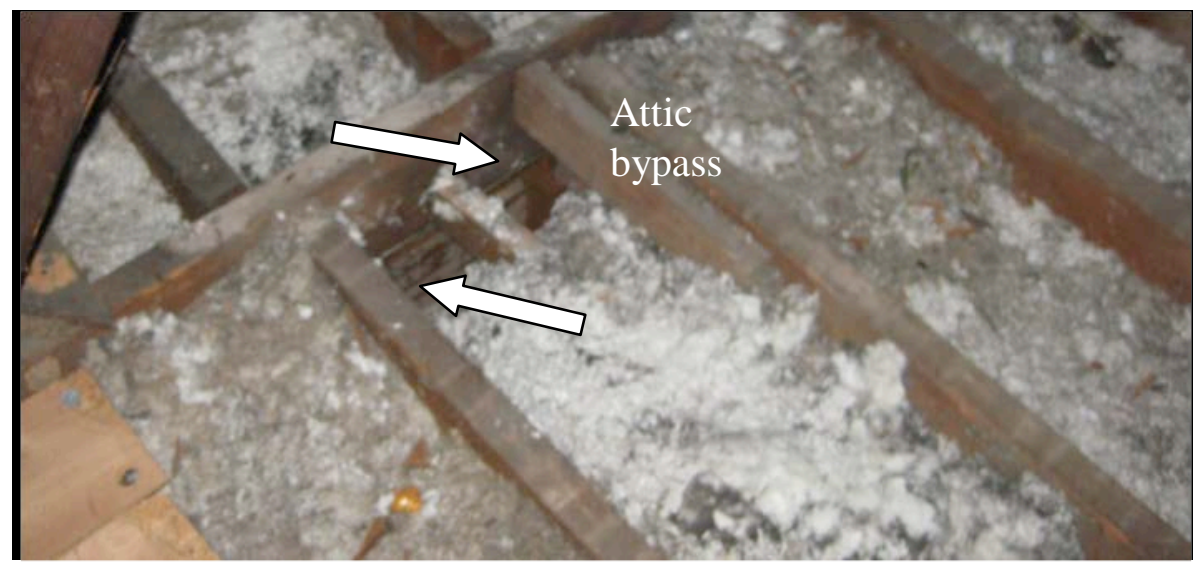

Figure 18. Photograph of attic bypass to interior walls.

As shown in Figure 18, loose fill was present in the attic ceiling with a range of coverage equivalent to insulation values that averaged R-11. However, while insulation was present, the consistency was limited. There were places in the attic ceiling that were insulated with packing peanuts (Figure 19).

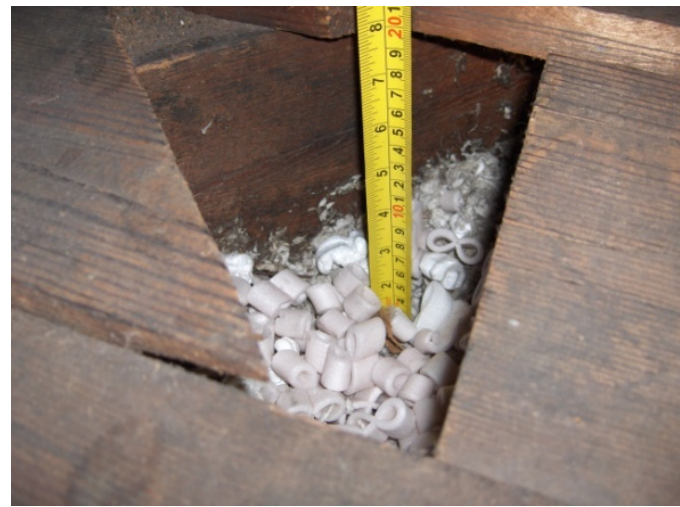

Figure 19. Packing peanuts used as insulation. 
Given the age of Michigan, exterior wall insulation was not expected. To aid in the building assessment, thermal infrared imaging was done. The assessment was performed as early in the morning as permitted by the tenant (around 7:00 a.m.) before the building gained a great amount of solar load from the rising sun. Through the thermal scan and visual inspection of the house, no insulation was evident in exterior walls of the home (Figure 20).

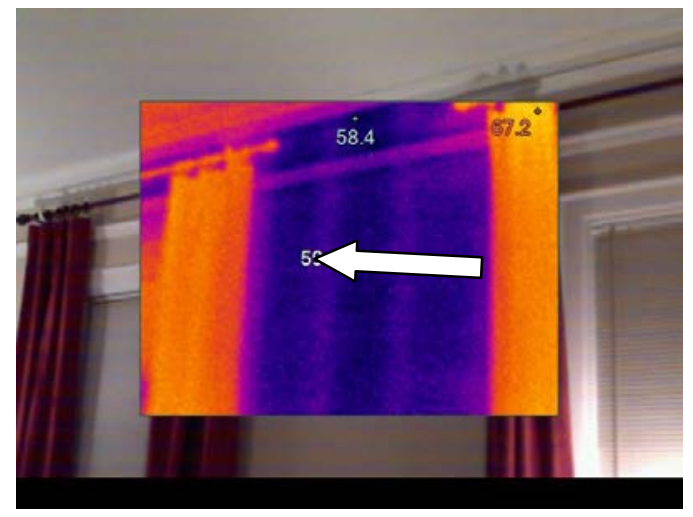

Figure 20. Thermal image of an exterior wall in Michigan. The arrow in the figure highlights the absence of insulation in the wall cavities between the studs.

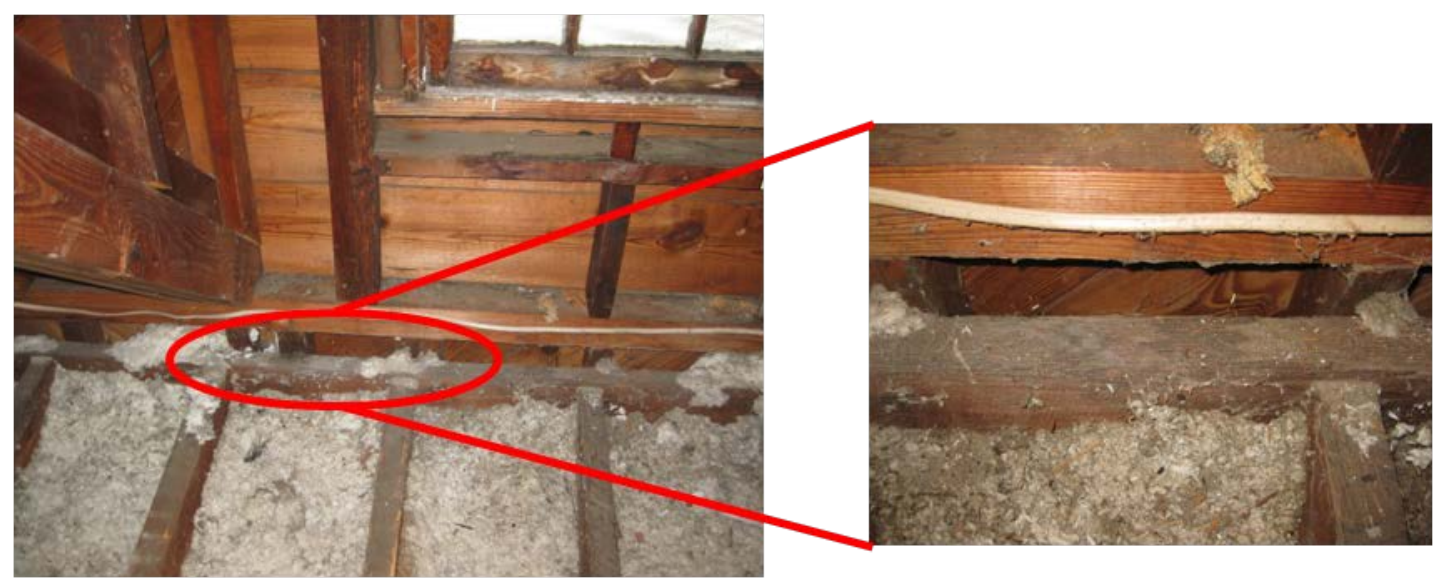

Figure 21. Photograph of an attic bypass in the exterior wall.

In the ceiling of the crawlspace (i.e. subfloor), there were R-13 fiberglass batts that were recently installed (Figure 22). The batts were installed with the kraft paper side down (i.e. toward the ground and not in contact with the subfloor), which is not consistent with recommended installation practices in the mixed-humid climate zone. In this zone, manufacturers recommend that the faced side of the batts touch the warm winter-time surface (i.e. the subfloor) in order to prevent condensation and moisture problems. Because the batts are intended for installation in a 3.5” thick cavity, but are installed in a 9.5” thick cavity, there is a significant gap between the batt insulation and the subfloor. 
The windows in this home are all single pane windows with wood frames. Michigan also has a whole-house fan, which is not used by the family that lives there.

During the initial home energy assessment, a Blower Door test was conducted to evaluate the air infiltration. The total air leakage rate was 9,840 $\mathrm{CFM}_{50}$. With a conditioned volume of 39,853 $\mathrm{ft}^{3}$, the air exchange rate for Michigan was approximately $14.8 \mathrm{ACH}_{50}$.

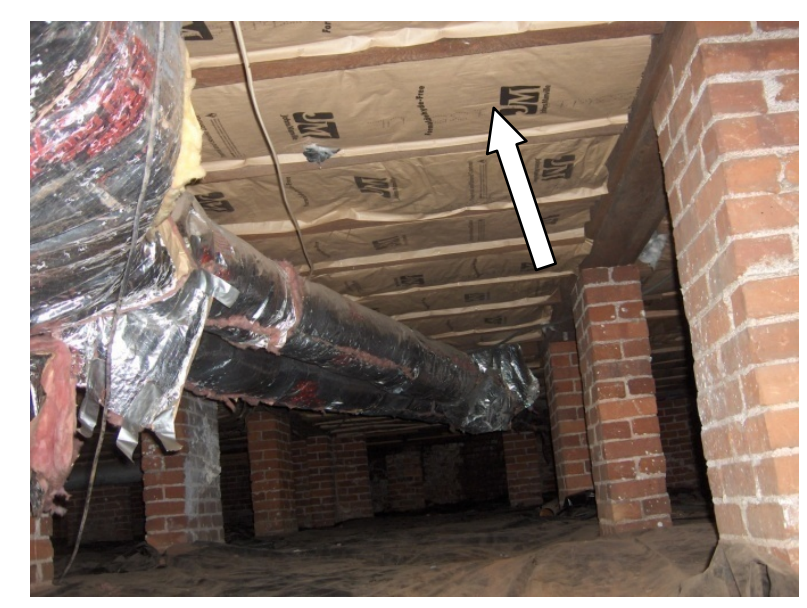

Figure 22. Photograph of the R-13 batts installed in crawlspace ceiling.

\section{HVAC}

Conditioned air is provided in Michigan by two HVAC systems. The first system served the main section of the home and had a 3.5 ton capacity air conditioner, with an efficiency of 9 SEER. The heating for the main section of the home was provided by a natural gas furnace with a $115 \mathrm{kBtuh}$ capacity and a rating of 80 AFUE. Similarly, the air conditioner that served the master suite had a 2 ton capacity and a rated efficiency of 10.1 SEER. The natural gas furnace had a $45 \mathrm{kBtuh}$ capacity with an efficiency rating of 91 AFUE. The HVAC systems for both the master suite and the main section were located in the crawlspace.

The ducts for both systems were insulated with R-6 insulation and were located in the crawlspace. Duct leakage tests were performed for both systems. However, in both cases, the ducts were too leaky to be pressurized. This is in large part due to the fact that panned joist return ducts were prevalent. There were cases found where the joists were only covered on the bottom and not between the cavities; thereby leaving an open cavity.

\section{Lighting, Water Heating, Appliances}

There were two natural gas fired water heaters with a 40 gallon capacity that were located in the vented crawlspace. One had an efficiency rating of 0.58 EF, while the other was rated at 0.57. The house had 35\% CFL lighting and no ENERGY STAR appliances. Both the range and oven were gas powered.

\section{Health and Safety}


A thorough combustion safety test was performed on the water heaters, furnace, oven, and range. While the units are considered to be outside of the envelope, the major air leakage pathways connect the area to the living space. All units passed all components of the combustion safety test: spillage, draft, and CO. No gas leaks were detected. 


\section{Retrofit Measures}

Using the prioritization protocol for this retrofit study, the following retrofit priorities were determined.

Table 8. Michigan priority list

\begin{tabular}{|l|l|c|}
\hline \multicolumn{1}{|c|}{ Improvement } & \multicolumn{1}{c|}{ Existing condition } & Priority \\
\hline Air sealing & $\sim 0.75 \mathrm{ACH}_{\text {natural }}$ & $\mathrm{A}$ \\
\hline Improve ducts & Could not pressurize & $\mathrm{A}$ \\
\hline $\begin{array}{l}\text { Insulate ATTIC (attic floor air sealing } \\
\text { must precede insulation work) }\end{array}$ & $\mathrm{R}-18$ & $\mathrm{~B}$ \\
\hline Insulate ATTIC KNEE WALLS & $\begin{array}{l}\text { Insulated, unsheathed or incomplete } \\
\text { sheathing }\end{array}$ & $\mathrm{B}$ \\
\hline Insulate WALLS & None & $\mathrm{C}$ \\
\hline Insulate FLOOR & Any & $\mathrm{C}$ \\
\hline Insulate BASEMENT/CRAWLSPACE & None & $\mathrm{B}$ \\
\hline WALLS & No radiant barrier & $\mathrm{D}$ \\
\hline Radiant barrier & $\begin{array}{l}80 \text { AFUE (Main) } \\
\text { 91 AFUE(Master suite) }\end{array}$ & $\mathrm{C}$ \\
\hline Replace heating system & 9 SEER(Main) & $\mathrm{D}$ \\
\hline Replace cooling system & 10.1 SEER (Master suite) \\
\hline Replace water heater & .58 and .57 gas & $\mathrm{B}$ \\
\hline Insulate water heater and pipe & Gas water heater & $\mathrm{D}$ \\
\hline Improve windows & Wood single-pane & $\mathrm{C}$ \\
\hline
\end{tabular}

Measures that received a priority of A or B from the prioritization protocol listed in Table 8 were used as a basis for discussion with the homeowner and retrofit contractor on determining the final retrofit package. Retrofit measures included in the final package are described in the following text.

\section{Envelope}

As can be seen in the retrofit priority list in Table 8, air sealing and attic insulation were categorized as A and B priorities, respectively. As such, the ceiling plane is a primary point of focus in completing these measures. Insulation subcontractors air sealed around the electrical penetrations, can lights, and typical plumbing penetrations. They also used rigid foam board to flash the chase around the chimney. As previously discussed, the balloon-framed walls did not have top plates in the exterior walls to separate the attic from the exterior walls. To address this, open-cell foam was sprayed in the gap to serve as an air barrier between the attic and the walls. In some places, there was an open chase adjacent to the exterior wall. In these cases, rigid foam board was cut and flashed with foam to create the air barrier. Two photographs that show how the attic bypasses were addressed in the exterior walls are shown in Figure 23.

\footnotetext{
${ }^{15}$ ACHnatural $=\mathrm{ACH}_{50} / \mathrm{N}_{\text {corrected }}$, where $\mathrm{N}_{\text {corrected }}$ is the height-corrected LBL " $\mathrm{N}$-factor" (http://www.bpi.org/Web\%20Download/BPI\%20Standards/Building\%20Analyst\%20Professional_2-28-05nNCnewCO.pdf)
} 

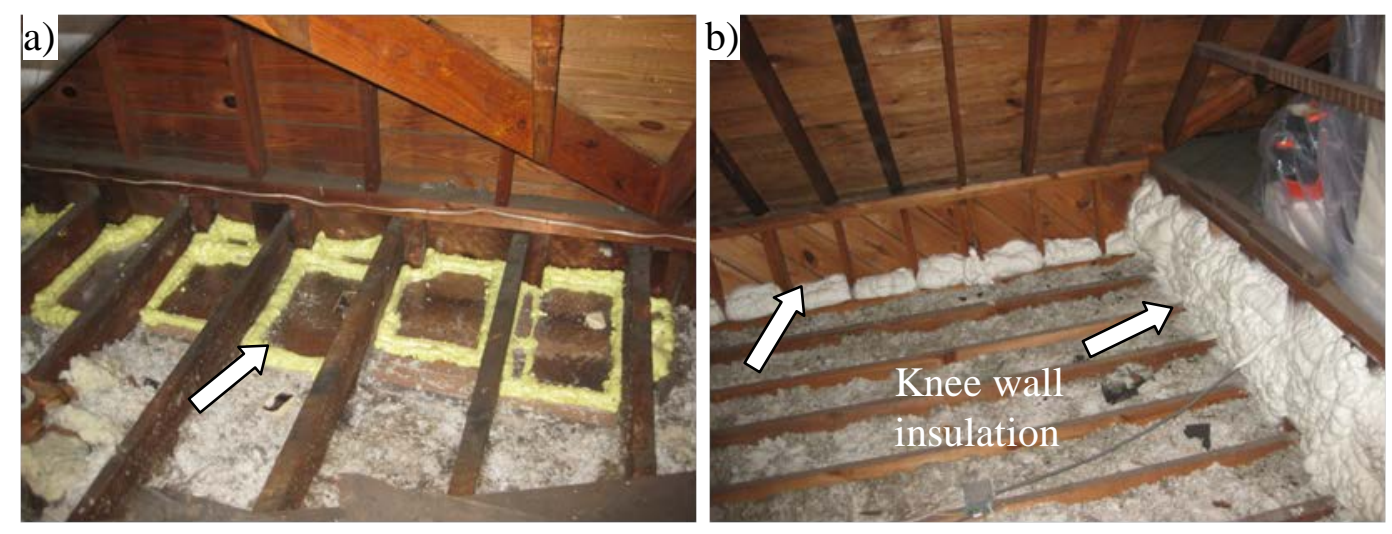

Figure 23. a) Photograph of rigid foam board applied in an attic bypass adjacent to an exterior wall. b) Photograph of open-cell spray foam applied in exterior wall bypasses. Insulation on knee walls is also shown in the picture.

The R-13 batt insulation originally in the attic knee walls was removed and replaced with a low density, open-cell foam sprayed to a thickness equal to an approximate insulation value of R-15. The spray foam provides insulation and air sealing properties to effectively align the thermal and air barriers. An example of the open-cell spray foam applied on the knee walls is shown in Figure 23. After air sealing was completed, the ceiling plane was insulated with blown fiberglass insulation for an approximate insulation value of R-38. All attic accesses were weather-stripped and insulated with R-5 Thermax boards. Since the whole-house fan was not in use. It was removed and capped with rigid foam board flashed with spray foam to create an air and thermal barrier to the living space.

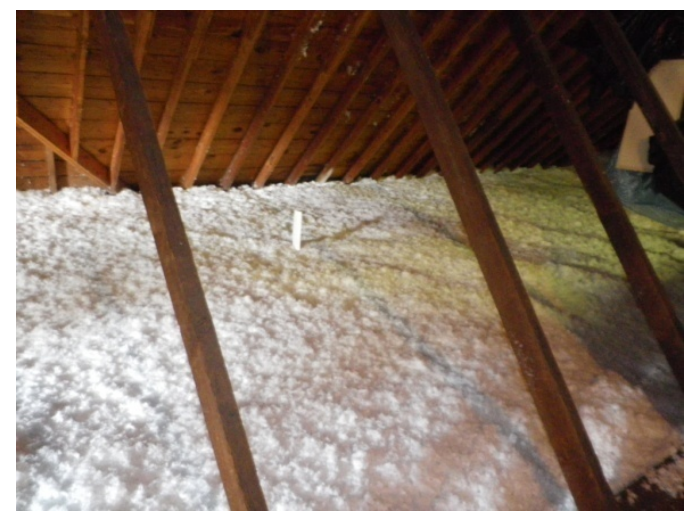

Figure 24. Blown fiberglass insulation applied in the attic ceiling (R-38).

In the crawlspace, the existing fiberglass batts in the subfloor were removed so that penetrations through the subfloor could be sealed. The batts were reinstalled with the faced side against the floor to be consistent with recommended best practices to mitigate risks associated with moisture and condensation. The crawlspace band was also insulated with 2.5” of open-cell foam to an R- 
11 insulation value. By insulating the exposed band with spray foam, infiltration from the crawlspace through the wall cavities is reduced.

\section{HVAC}

The air conditioning unit in the crawlspace that provided space conditioning for the main section of Michigan was replaced with a 3.5 ton capacity, 14.5 SEER unit. The heating unit was replaced with an 89 kBtuh 95 AFUE sealed-combustion gas furnace. For the master suite, the existing air conditioner was replaced with a 2 ton, 14.5 SEER unit. A MERV 10 filter rack was also installed in both systems. In both HVAC systems, the ducts were removed and replaced with new R-8 insulated flex duct.

\section{Lighting, Water Heating, Appliances}

One of the water heaters was not replaced. One was replaced because it was in need of repair before the retrofit began. No lighting upgrades were made.

\section{Health and Safety}

Combustion safety issues were addressed in the atmospherically vented water heater. All combustion units passed all aspects of the combustion safety test: spillage, draft, and CO. No gas leaks were found.

\section{Simulated Energy Savings}

Table 9 shows the simulated energy savings from the implemented retrofit measures. In total, there is an estimated $27 \%$ reduction in source energy consumption. The predicted source energy savings from envelope and HVAC improvements were $11 \%$ and $13 \%$ respectively. The envelope improvements that include air sealing and thermal insulation measures taken on the knee walls, attic accesses and bypasses, crawlspace subfloor, and the crawlspace band only predicted moderate source energy savings. At the time of this publication, the homeowners had not decided to undertake lighting improvements. However, the impact is included in this section to demonstrate the added savings these improvements could yield.

Table 9. Michigan recommended package with simulated energy savings from EnergyGauge

\begin{tabular}{|l|l|r|l|l|}
\hline & $\begin{array}{l}\text { Predicted Site } \\
\text { Energy } \\
\text { (MMBtu) }\end{array}$ & $\begin{array}{l}\text { Predicted Source } \\
\text { Energy (MMBtu) }\end{array}$ & $\begin{array}{l}\text { Site Energy } \\
\text { Savings (\% per } \\
\text { measure) }\end{array}$ & $\begin{array}{l}\text { Source Energy } \\
\text { Savings (\% per } \\
\text { measure) }\end{array}$ \\
\hline $\begin{array}{l}\text { Michigan Simulated } \\
\text { Energy Use }\end{array}$ & 195 & 334 & $13 \%$ & $11 \%$ \\
\hline $\begin{array}{l}\text { + Envelope } \\
\text { Improvements }\end{array}$ & 171 & 299 & $13 \%$ & $13 \%$ \\
\hline $\begin{array}{l}++ \text { HVAC System } \\
\text { Improvements }\end{array}$ & 146 & 257 & $1 \%$ & $4 \%$ \\
\hline $\begin{array}{l}++ \text { Lighting } \\
\text { Improvements }\end{array}$ & 143 & 245 & $27 \%$ & $27 \%$ \\
\hline $\begin{array}{l}\text { Total Retrofit } \\
\text { Investment }\end{array}$ & & & & \\
\hline
\end{tabular}


While substantial measures are modeled, the energy savings are tempered due to the family's conservation behaviors. As previously discussed, temperature set points in Michigan are $78^{\circ} \mathrm{F}$ in the summer and in the winter, $58^{\circ} \mathrm{F}$ at night and a typical range of $62-68^{\circ} \mathrm{F}$ in the day. However, as can be seen in Figure 25, the energy savings for the primary building loads are significant. The heating and cooling load energy savings are 31\% and 51\%, respectively. In accounting for lighting improvements suggested in this retrofit, the reduction in heating load resulting from incandescent light bulbs offsets some of the heating savings. Conversely, as the heating savings decreased, the cooling savings increase.

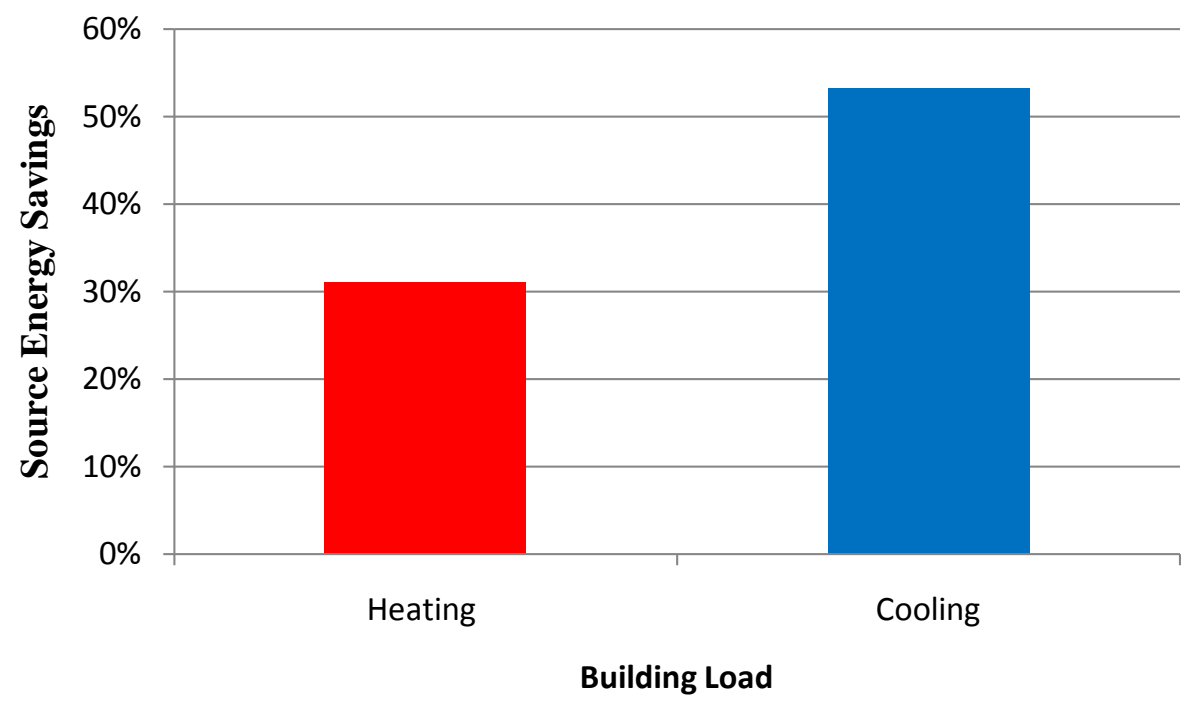

Figure 25. Simulated Energy Savings from Heating and Cooling Loads

\section{Diagnostics and Test Out}

When scheduling with subcontractors permitted, Blower Door tests were done at intervals to investigate the effectiveness of individual retrofit measures. The results are shown in Table 10 in the order in which the tests were done. Conducting successive diagnostic Blower Door tests can yield valuable information and insight into the impact of individual measures and facilitate more accurate prediction of energy savings. For example, as seen in the table, undergoing air sealing in the attic can yield significant infiltration reductions. A decrease of $2190 \mathrm{CFM}_{50}(17 \%$ of the total building infiltration) was achieved through attic air sealing. In contrast, applying lowdensity, open-cell spray foam to the crawlspace band joist only yielded a $6 \%$ reduction in air infiltration (470 $\left.\mathrm{CFM}_{50}\right)$. In total, air infiltration was reduced by approximately $22 \%$. 
Table 10. Pre-retrofit and post-retrofit air infiltration diagnostics

\begin{tabular}{|c|c|c|}
\hline Retrofit Measure Tested & $\begin{array}{l}\text { Blower Door Test Result } \\
\left(\mathrm{CFM}_{50} / \mathrm{ACH}_{50}\right)\end{array}$ & Percent Reduction $^{16}$ \\
\hline Initial & $9,843 / 14.8$ & \\
\hline $\begin{array}{l}\text { Attic Sealing + Whole-House } \\
\text { Fan Removal + Bypasses } \\
\text { Capped }\end{array}$ & 8,123 / 12.2 & $17 \%$ \\
\hline $\begin{array}{l}\text { Crawlspace Band Sealed with } \\
\text { Open-Cell Foam + Subfloor Air } \\
\text { Sealing }\end{array}$ & $7,657 / 11.5$ & $6 \%$ \\
\hline Final & $7,657 / 11.5$ & $22 \%$ \\
\hline
\end{tabular}

The impact of replacing the ducts is shown in Table 11. Whereas initially, the substantial duct leakage to the outside of the building envelope was such that the ducts could not be pressurized to permit measurement, after the retrofit, there is $160 \mathrm{CFM}_{25}$ of leakage in the system that provides conditioning to the master suite.

Table 11. Duct Blaster tests results for the Michigan house - duct leakage to outside measured as air flow at $25 \mathrm{~Pa}\left(\mathrm{CFM}_{25}\right)$ and normalized as a percentage $\left(\mathrm{CFM}_{25} /\right.$ conditioned area $\left.\left(\mathrm{ft}^{2}\right)\right)$

\begin{tabular}{|c|c|c|c|c|}
\hline & \multicolumn{2}{|c|}{$\begin{array}{c}\text { System 1* } \\
\text { (Main section) }\end{array}$} & \multicolumn{2}{c|}{$\begin{array}{c}\text { System 2** } \\
\text { (Master suite). }\end{array}$} \\
\hline & CFM $_{25}$ & \% Leakage to Outside & CFM $_{25}$ & \% Leakage to Outside \\
\hline Initial & \multicolumn{2}{|c|}{ Could not pressurize } & & \multicolumn{2}{c|}{ Could not pressurize } \\
\hline Post & 1143 & $45 \%$ & 160 & $22 \%$ \\
\hline
\end{tabular}

* The conditioned area is equal to $2,650 \mathrm{ft}^{2}$.

** The conditioned area is equal to $730 \mathrm{ft}^{2}$.

There remains substantial duct leakage in the system that serves the main section of the house. While the test-out leakage is better than the test-in duct leakage, the ducts are still considered very leaky. After the retrofit contractor was made aware of large remaining amount of duct leakage, he and the HVAC sub-contractor reevaluated the ducts to find leakage areas, but were unsuccessful. A potential source of the remaining duct leakage could be attributed to the supply and return registers that are mounted in the walls, in contrast to being mounted in the floor, as shown in Figure 26. When registers are located in walls, there is a potential for significant leakage in the cavity area that is not accessible from the crawlspace subfloor. In these cases, it is difficult to access the building cavity without damaging the interior wall finish.

\footnotetext{
${ }^{16}$ Percent reduction is determined by evaluating the $\mathrm{cfm} 50$ reduction for each of the retrofit measures as a ratio of the total building infiltration.
} 


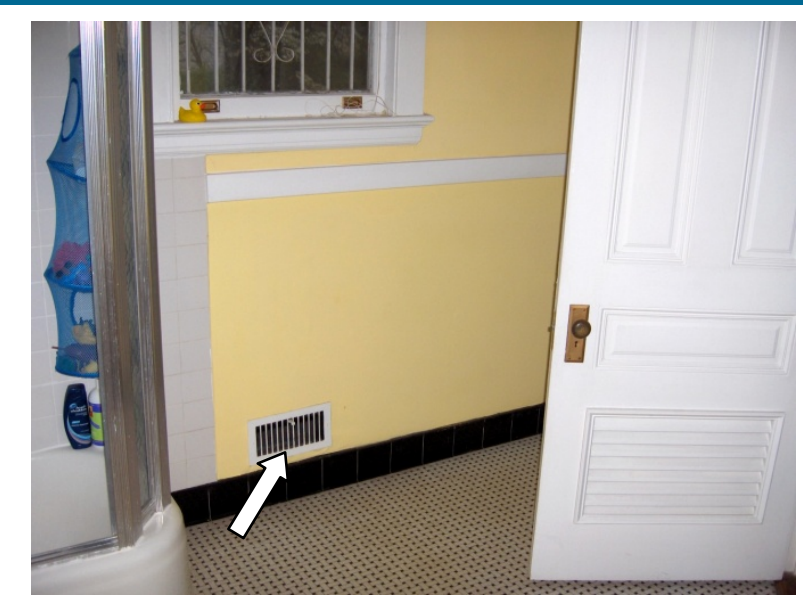

Figure 26. Photograph of supply register located in the wall.

The high duct leakage in this case illustrates a common retrofit scenario where planned improvements do not result in expected performance. Revisiting the home to identify more improvements is difficult given the competing constraints on the amount of time a building contractor can commit to returning to a home to conduct more investigation versus the degree of "annoyance" a homeowner can reasonably be expected to tolerate. A particular "annoyance", and therefore a significant barrier to returning to the home for more duct leakage analysis, is the time away from work that a homeowner must take to be at the home during the building retrofit. New construction, renovations, and rehabilitations may be similar in terms of disruption, but are not often subject to the requirement that the homeowner be on-site and therefore off-work. In this home, the services of a home energy consultant were offered to identify additional improvements; however, the building owner declined this service to try to minimize the disruption to the tenant's life.

Overall the final HERS index improved from 167 to 108, which reflects the significant energy savings that are predicted for this retrofit. Planned for FY12 is submetering of whole-house energy consumption, along with the contribution of major loads such as the air conditioner with an e-Monitor device. Additionally, utility bills will continue to be collected for comparison with pre-retrofit utility bills.

\section{Michigan Costs and Scope of Work}

The retrofit measures described in this report were completed in August 2011, at a total cost of about $\$ 27,950$. Table 12 provides a summary of the final scope of work and breakdown of the costs. 
Table 12. Michigan final scope of work and costs.

\begin{tabular}{|c|c|c|c|}
\hline Home Characteristics & $\begin{array}{l}\text { Pre-Retrofit } \\
\text { Conditions }\end{array}$ & Retrofit Measures & Final Costs \\
\hline $\begin{array}{c}\text { Attic/ } \\
\text { Knee walls }\end{array}$ & $\begin{array}{l}\text { R-18 blown fiberglass } \\
\text { (flat ceiling)/ } \\
\text { R-11 fiberglass batts } \\
\text { (knee walls) }\end{array}$ & $\begin{array}{l}\text { R-38 (flat ceiling)/ } \\
\text { R-15 (knee walls)/ } \\
\text { Attic bypasses air sealed; } \\
\text { Whole house fan removed } \\
\text { and sealed; } \\
\text { Chimney capped }\end{array}$ & $\$ 7,330$ \\
\hline Foundation & $\begin{array}{l}\mathrm{R}-13 \text { fiberglass batts in } \\
\text { the subfloor }\end{array}$ & $\begin{array}{l}\text { Air sealing around chases } \\
\text { and penetrations; } \\
\text { Reinstalled batt insulation }\end{array}$ & $\$ 4280$ \\
\hline Foundation Walls & $\mathrm{R}-0$ & $\begin{array}{l}\text { R-11 open-cell spray foam } \\
\text { on crawlspace band; } \\
\text { New } 12 \text {-mil vapor barrier }\end{array}$ & $\$ 4, \angle 00$ \\
\hline \multirow[b]{2}{*}{ Cooling } & 3.5 ton, 9 SEER(Main) & 3.5 ton, 14.5 SEER (Main) & \multirow{4}{*}{$\$ 16,340$} \\
\hline & $\begin{array}{l}2 \text { ton, } 10 \text { SEER } \\
\text { (Master suite) }\end{array}$ & $\begin{array}{l}2 \text { ton 14.5 SEER (Master } \\
\text { suite) }\end{array}$ & \\
\hline \multirow{2}{*}{ Heating } & $\begin{array}{l}75 \text { kBtuh } 80 \text { AFUE } \\
\text { (Main) }\end{array}$ & \multirow[t]{2}{*}{89 kBtuh 95 AFUE (Main) } & \\
\hline & $\begin{array}{l}115 \text { kBtuh } 91 \text { AFUE } \\
\text { (Master suite) }\end{array}$ & & \\
\hline
\end{tabular}




\section{North Carolina}

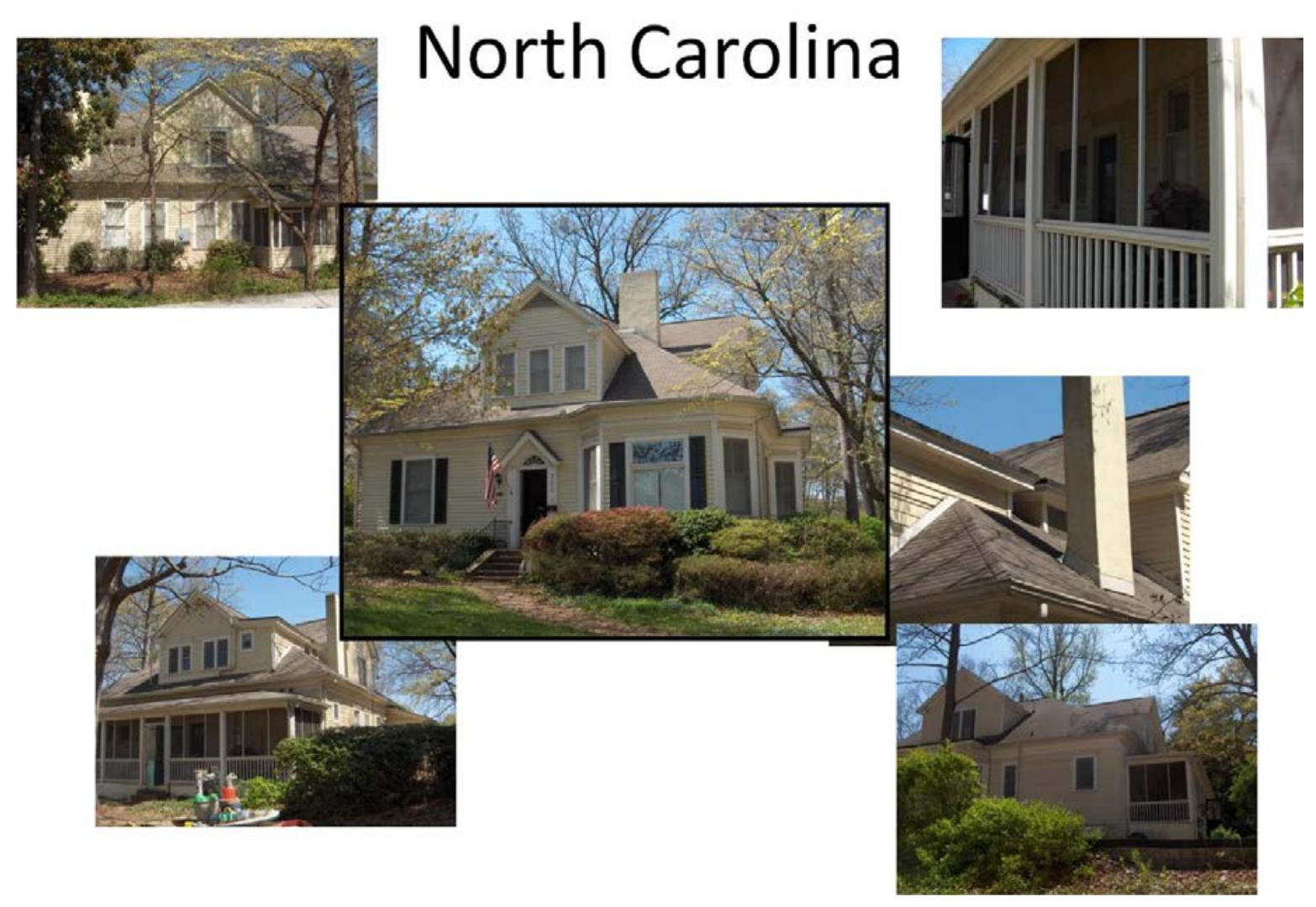

\section{North Carolina Home Profile}

Originally built in the 1920s, North Carolina is a two-story, single-family detached home with $3,710 \mathrm{ft}^{2}$ of living area. The first floor has a living area of $2,410 \mathrm{ft}^{2}$, while the second floor has $1,300 \mathrm{ft}^{2}$. North Carolina is home to a family of two adults and three children. The home has five bedrooms and three bathrooms. Two bedrooms are located on the first floor, while the remaining three are on the second floor. North Carolina has a traditional vented attic and a vented crawlspace.

A primary concern for the family that lives in North Carolina is the high costs of their energy bills. As shown in Figure 27, from February 2010 - January 2011, the total energy costs were $\$ 6,380$ (296 MMBtu of site energy). In contrast, a typical home in the southeast of this size is expected to have an average annual site energy consumption of $176 \mathrm{MMBtu}^{17}$. In spite of the high energy costs of this home, discussion with the family revealed that the second floor temperature and humidity levels were often intolerable. In the summer cooling months, the

\footnotetext{
${ }^{17}$ Per the 2010 Buildings Energy Data Book, energy consumption for the South Atlantic region is 47.4 kBtu per square foot.
} 
temperature on the second floor did not reach the targeted set point and often did not go below $80^{\circ} \mathrm{F}$. The family often operated portable electric fans to compensate for the lack of comfort provided by the existing system. In the winter heating season, the family relied mostly on portable space heaters to provide heat at night. During the winter days, the second floor was primarily unoccupied.

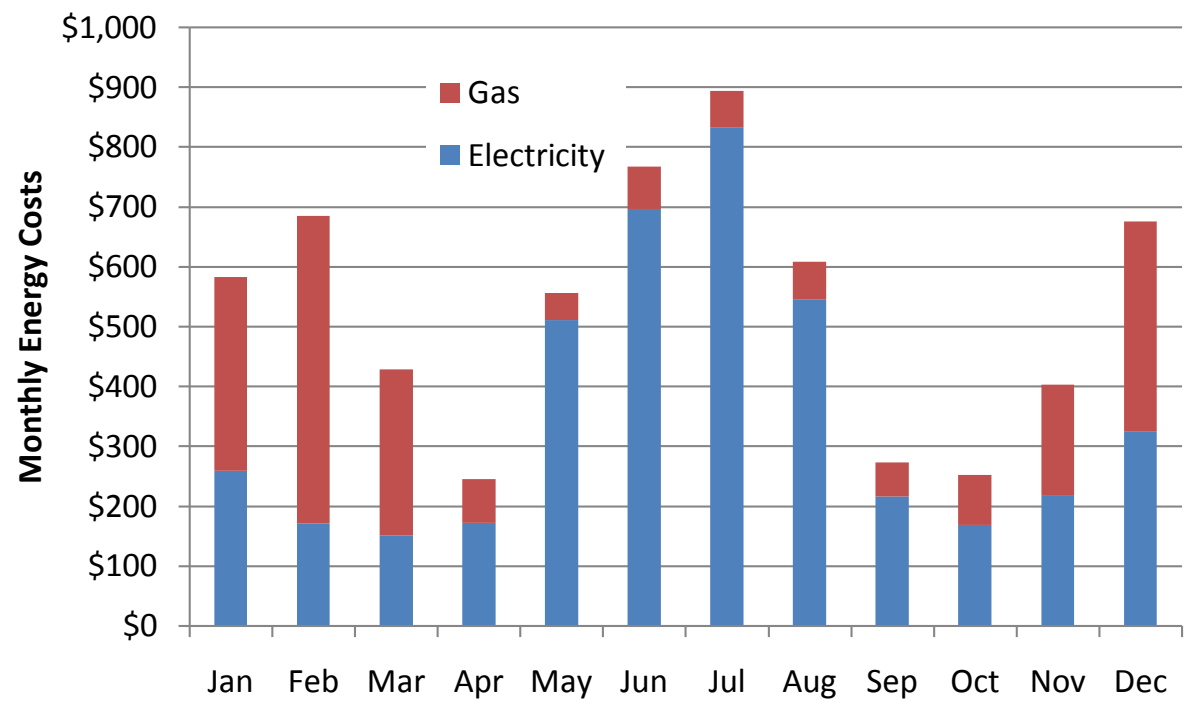

Figure 27. North Carolina monthly energy costs

\section{North Carolina Initial Characteristics}

\section{Envelope Profile}

The building envelope is bounded by a framed floor above the vented crawlspace and an insulated ceiling plane above the first and second floors. The interior ceiling height for this home is 8 feet. Shown in Figure 28is an illustration of the initial envelope profile. The dark green color represents the attic knee walls. As seen in the figure, there is significant attic exposure through knee walls. Approximately $60 \%$ of the exterior walls on the second floor are knee walls. The amount of knee wall surface area that did have insulation in the form of R-13 batts was quite limited, such that no insulation was assumed. These uninsulated knee walls allow heat from the attic to conduct through the walls into the living space. Heat is also transferred to/from the second floor from/to the attic through the many bypasses that exist. Two example bypasses are shown in Figure 29. In addition to the fact that the attic access shown in the figure was not insulated and does not have any weather-stripping, there was no mechanism in place to ensure that it remained closed. Based on the second floor living area's exposure to the attic via conduction through uninsulated knee walls, or by convection through attic bypasses, the low level of thermal comfort expressed by the family living in North Carolina is understandable. Because of the lack of a consistent and effective thermal and pressure boundary from the attic, it is almost within reason to describe the second floor living area as existing inside the attic. 


\section{NORTH CAROLINA PRE-}

RETROFIT

CHARACTERISTICS

TYPE: Two-story, single-family home

SIZE: $3,710 \mathrm{ft}^{2}$

Occupancy: Two adults, three children

\section{INITIAL ENVELOPE}

\section{PROFILE}

WALL INSULATION: None BAND INSULATION: None FOUNDATION SUBFLOOR

INSULATION: R-0

ATTIC INSULATION: R-11 - R19

KNEEWALL INSULATION: R-0

\section{INITIAL MECHANICAL}

\section{PROFILE}

FIRST FLOOR ZONE

Location: Unconditioned

crawlspace

Cooling: 9 SEER (electric)

Heating: 91 AFUE (natural gas)

SECOND FLOOR ZONE

Location: Vented attic Cooling: 9 SEER (electric) Heating: 91 AFUE (natural gas)

\section{WATER HEATER: $0.59 \mathrm{EF}$}

\section{INITIAL DIAGNOSTIC}

\section{RESULTS}

HERS: 169

HESCORE: 1

AIR INFILTRATION:

$12,690 \mathrm{CFM}_{50}\left(20.6 \mathrm{ACH}_{50}\right)$ DUCT LEAKAGE TO OUTSIDE:

$1^{\text {st }}$ floor: too high to measure

$2^{\text {nd }}$ floor: 280 CFM $_{25}$

DUCT INSULATION: R-6

COMBUSTION SAFETY TEST: All the units passed.

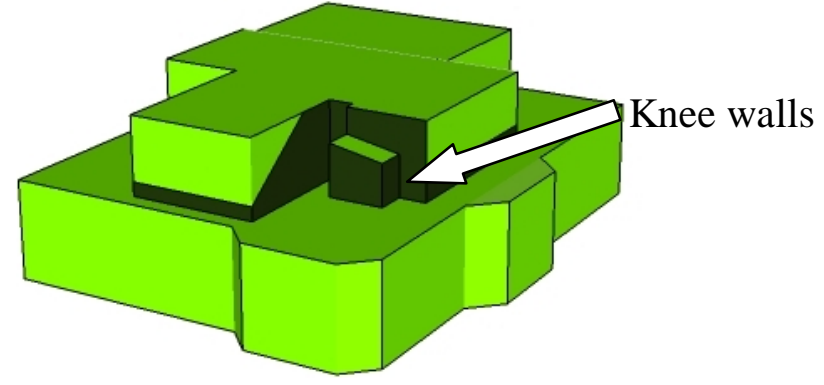

Figure 28. Illustration of North Carolina's initial building profile.
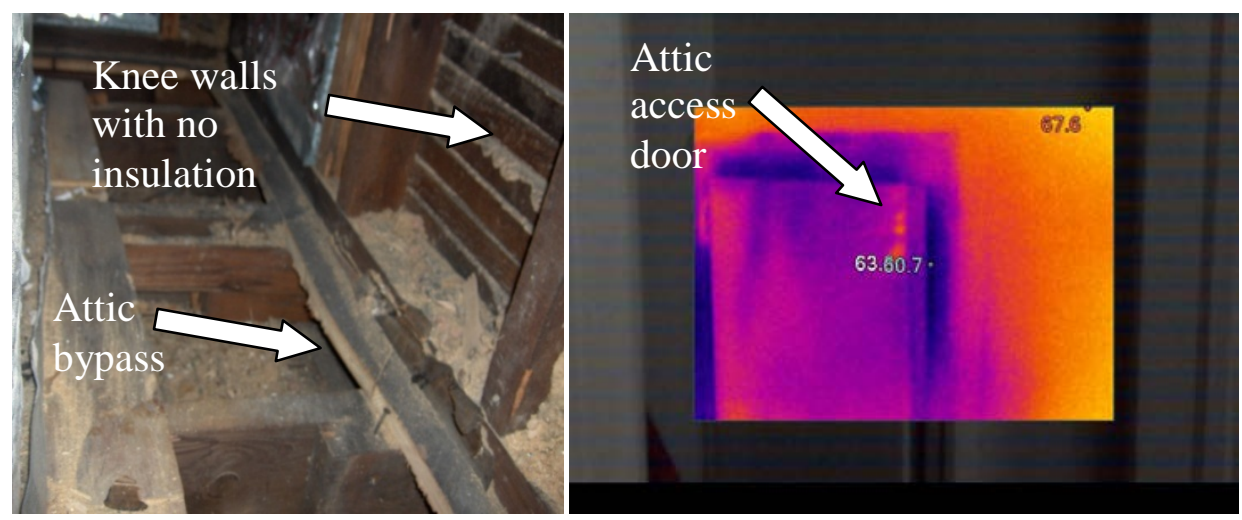

Figure 29. Attic bypasses. On the right is a thermal image of the attic access door. The blue color in the image shows attic air infiltration into the living space.

To aid in the building assessment, thermal infrared imaging was done. The assessment was performed as early in the morning as permitted by the tenant (around 7:00 a.m.) before the building gained a great amount of solar load from the rising sun. Through the thermal scan and visual inspection of the house, no insulation was evident in exterior walls of the home (Figure 30). 


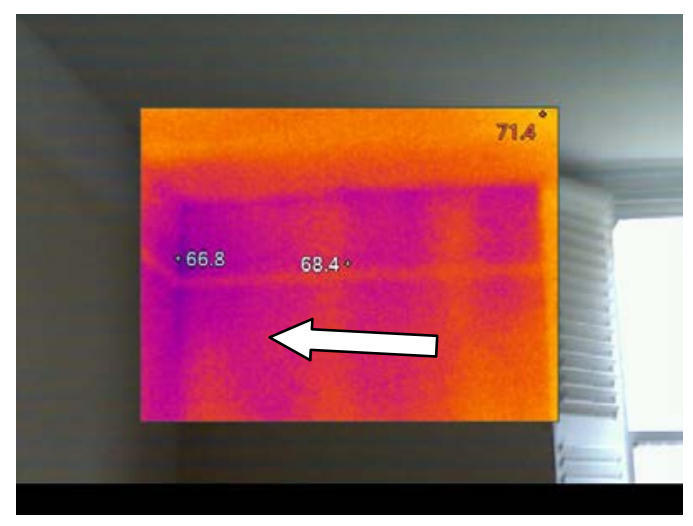

Figure 30. Thermal image of an exterior wall in North Carolina. The arrow in the figure highlights the absence of insulation in the wall cavities between the studs.

In the flat ceiling over the first floor, blown fiberglass insulation was present, with a range of coverage equivalent to insulation values up to R-11. Similarly, the blown fiberglass on the ceiling above the second floor ranged in thicknesses equivalent to insulation values up to R-9. However, while some insulation was present, the consistency was very limited.

In the ceiling of the crawlspace (i.e. subfloor), there were R-13 fiberglass batts that were recently installed. However, the batts were compressed between the floor joists such that the intended R13 insulation value was reduced. In addition, the batts were installed with the kraft paper side down (i.e. toward the ground and not in contact with the subfloor), which is not consistent with recommended installation practices in the mixed-humid climate zone. In this zone, manufacturers recommend that the faced side of the batts touch the warm winter-time surface (i.e. the subfloor) in order to prevent condensation and moisture problems. Because the batts are intended for installation in a 3.5” thick cavity, but are installed in a 9.5” thick cavity, there is a significant gap between the batt insulation and the subfloor.

A vapor barrier was present in places on the crawlspace floor but did not provide full coverage. A consistent coverage on the ground is needed to prevent potential moisture pathways, and thereby reduce the risk for mold growth and wood rot. In the areas where the vapor barrier did exist, it was not taped and overlapped to the crawlspace walls and stem walls extending up at least 6” from the ground, as is required by Georgia Energy Code in Section 402.2.9 ${ }^{18}$. Further visual inspection of the subfloor identified areas of air infiltration pathways into the conditioned space. These areas were most prevalent around plumbing and electrical penetrations.

The windows in this home are mostly double-hung double-pane windows with wood frames. Out of the 36 windows in North Carolina, 4 are single pane windows with wood frames. On the second floor, there were two windows which did not properly close, leaving a gap of approximately 3/4”.

${ }^{18}$ GA International Energy Conservation Code Supplements and Amendments 2011 
During the initial home energy assessment, a Blower Door test was conducted to evaluate the air infiltration. The total air leakage rate was 12,690 $\mathrm{CFM}_{50}$. With a conditioned volume of 36,980 $\mathrm{ft}^{3}$, the air exchange rate for North Carolina was approximately $20.6 \mathrm{ACH}_{50}$.

\section{HVAC}

Conditioned air is provided in North Carolina by two HVAC systems. The first floor has a 3.5 ton capacity air conditioner, with an efficiency of 9 SEER located in the crawlspace. Also located in the crawlspace is the gas furnace for the first floor, which has a capacity of $125 \mathrm{kBtuh}$ and a rating of 91 AFUE. This sealed-combustion furnace was recently installed in the home. The second floor HVAC system is located in the attic. The air conditioner has a 2.5 ton capacity and a 9 SEER rating. Similar to the first floor unit, the gas furnace was recently replaced with a 50 kBtuh, 91 AFUE unit.

The ducts for first floor HVAC system were located in the crawlspace. While the ducts were insulated with R-6 insulation, they were not very effective for delivering conditioned air. There were several disconnected duct connections (Figure 31) that made pressurizing the ducts to evaluate the overall leakage not possible.

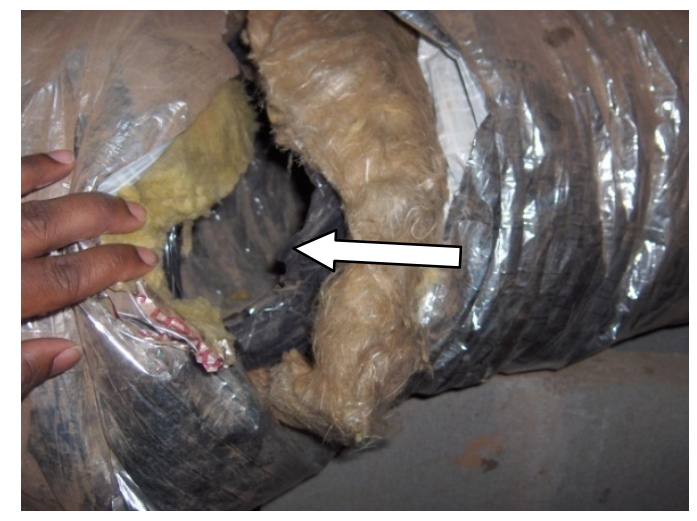

Figure 31. Disconnected ducts in the crawlspace

The ducts for the second floor HVAC system were located in the attic. Similar to the first ducts, R-6 insulation was used on the flex ducts. While much better than the first floor with regard to duct leakage, a duct blaster test revealed approximately $280 \mathrm{CFM}_{25}$ of leakage. This is equal to about $22 \%$ of the floor area served by this system.

\section{Lighting, Water Heating, Appliances}

The natural gas fired water heater is located in the vented crawlspace. It has a storage capacity of 40 gallons and is rated at $0.59 \mathrm{EF}$. The house has $2 \%$ CFL lighting and no ENERGY STAR appliances. Both the range and oven are electric.

\section{Health and Safety}

A thorough combustion safety test was performed on the water heater and furnace, because even though the units are considered to be outside of the envelope, there were major air leakage pathways that connect the area to the living space. Both units passed all components of the combustion safety test: spillage, draft, and CO. Gas leaks were detected. 


\section{Retrofit Measures}

Using the prioritization protocol for this retrofit study, the following retrofit priorities were determined.

Table 13. North Carolina priority list

\begin{tabular}{|l|l|c|}
\hline Improvement & Existing condition & Priority \\
\hline Air sealing & 1.3 ACHnatural ${ }^{19}$ & $\mathrm{~A}$ \\
\hline Improve ducts & $\geq 25 \%$ duct leakage & $\mathrm{A}$ \\
\hline $\begin{array}{l}\text { Insulate ATTIC (attic floor air sealing } \\
\text { must precede insulation work) }\end{array}$ & R-6- R-11 & $\mathrm{A}$ \\
\hline Insulate ATTIC KNEE WALLS & None & $\mathrm{B}$ \\
\hline Insulate WALLS & None & $\mathrm{C}$ \\
\hline Insulate FLOOR & None & $\mathrm{B}$ \\
\hline Insulate BASEMENT/CRAWLSPACE & None & $\mathrm{B}$ \\
WALLS & No radiant barrier & $\mathrm{D}$ \\
\hline Radiant barrier & 91 AFUE (crawl) & $\mathrm{D}$ \\
\hline Replace heating system & 91 AFUE (attic) & $\mathrm{D}$ \\
\hline Replace cooling system & 9 SEER (crawl) & $\mathrm{A}$ \\
\hline Replace water heater & 9.3 SEER (attic) & $\mathrm{A}$ \\
\hline Insulate water heater and pipe & .59 Gas & $\mathrm{C}$ \\
\hline Improve windows & Gas & $\mathrm{C}$ \\
\hline
\end{tabular}

Measures that received a priority of A or B from the prioritization protocol listed in Table 13 were used as a basis for discussion with the homeowner and retrofit contractor on determining the final retrofit package. Retrofit measures included in the final package are described in the following text.

\section{Envelope}

As can be seen in the retrofit priority list in Table 13, air sealing and attic insulation were categorized as A and B priorities, respectively. As such, the ceiling plane is a primary point of focus in completing these measures. Insulation subcontractors air sealed around the electrical penetrations, can lights, and typical plumbing penetrations. They also used rigid foam board to flash the chase around the chimney. In the limited knee wall areas where R-13 batt insulation was present, the batts were removed and replaced with a low density, open-cell spray foam. The spray foam provides insulation and air sealing properties to effectively align the thermal and air barriers. All attic accesses were weather-stripped and insulated with R-5 Thermax ${ }^{\circledR}$ boards. An example of attic access insulation and the open-cell spray foam applied on the knee walls is shown in Figure 32.

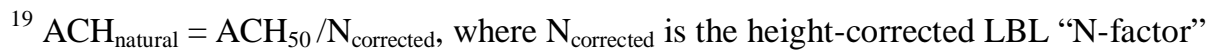
(http://www.bpi.org/Web\%20Download/BPI\%20Standards/Building\%20Analyst\%20Professional_2-28-05nNCnewCO.pdf)
} 


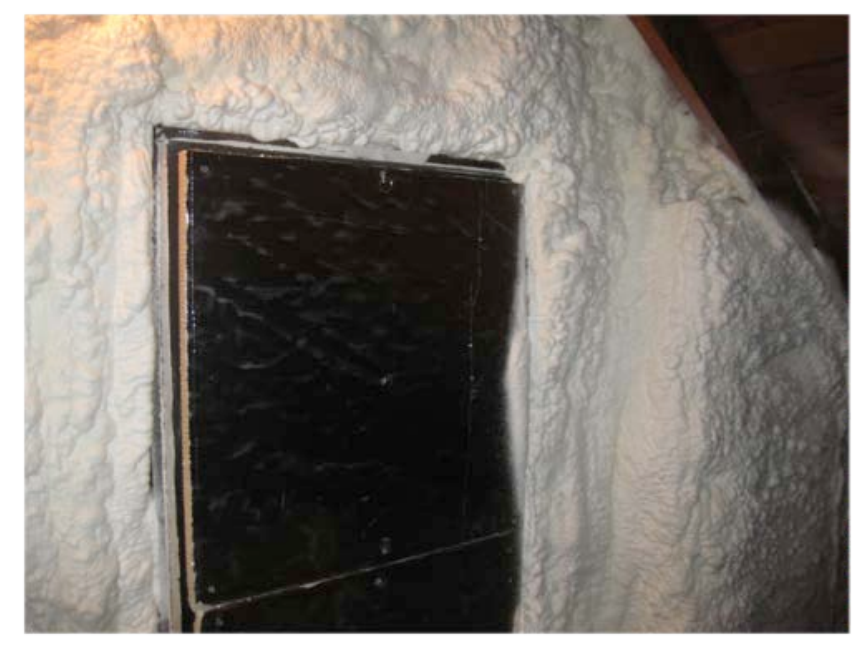

Figure 32. Insulation applied on the attic knee wall and the attic access door.

The crawlspace was encapsulated in North Carolina as a retrofit measure. In addition to the expected infiltration and moisture management improvement from sealing crawlspaces, there will also be improved HVAC performance, since the system is located in the semi-conditioned crawlspace. To encapsulate the crawlspace, the vents were covered and 2.5” of open-cell spray foam was applied over the cover along with the remainder of the band to yield an insulation level of approximately R-9. The foundation walls were also insulated and sealed with 3.5” closed-cell spray foam, yielding an insulation value of approximately R-19. Prior to the foam application, a 12-mil vapor barrier, which addresses moisture management risks from the ground, was flashcoated to the walls with foam to ensure that at least 6" of the plastic adhered to the foundation walls. The closed-cell foam was then sprayed over the plastic. Per code, a 3" termite inspection strip was created for inspection purposes. The crawlspace door was insulated with rigid foam board and weather-stripped. Photographs of the crawlspace ceiling are shown in Figure 33.
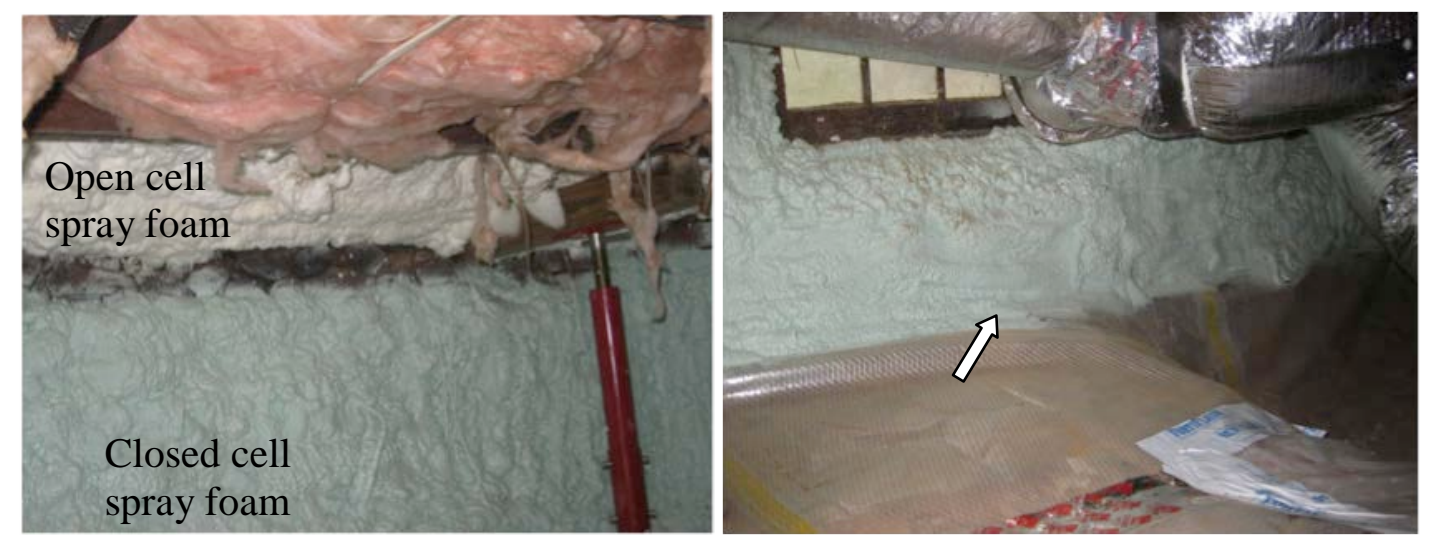

Figure 33. Crawlspace sealing and vapor barrier installation. The arrow in the picture on the right highlights the open-cell spray foam applied over the vapor barrier. 


\section{HVAC}

The air conditioning unit in the crawlspace that provided space conditioning for the first floor was replaced with a 4 ton capacity, 16 SEER air conditioner. The second floor air conditioner was replaced with a 2.5 ton, 16 SEER unit. In both cases, the ducts were removed and replaced with new R-8 insulated flex duct. As previously discussed, the ducts in the crawlspace are now considered a part of the semi-conditioned volume, since the vents in the crawlspace were blocked and insulated.

\section{Lighting, Water Heating, Appliances}

The water heater was upgraded to a 50 gallon Rheem Heat Pump Water Heater with a 2.0 EF. Neither the lighting nor the appliances were upgraded.

\section{Health and Safety}

Combustion safety issues were addressed by replacing the atmospherically vented water heater to an electric heat pump water heater.

\section{Simulated Energy Savings}

Table 14 shows the simulated energy savings from the implemented retrofit measures. In total, there is an estimated 38\% reduction in source energy consumption. As shown in Figure 28 and Figure 29, and discussed earlier, it is within reason to describe the second floor living area as existing inside the attic in the pre-retrofit case. However, since significant air sealing and thermal insulation measures were taken on the knee walls and attic accesses, the predicted source energy savings of $18 \%$ are substantial. Additionally, because of the significant amount of duct leakage in the pre-retrofit case, coupled with the poor efficiency of the air conditioning unit, large source energy savings of $20 \%$ are projected based on improvements in the HVAC system. Because the ducts could not be pressurized initially, it was difficult to accurately predict the energy savings due to duct improvements in our modeling. For modeling purposes, we estimated an initial duct leakage of approximately $840 \mathrm{CFM}_{25}$. This is equivalent to about $35 \%$ of the conditioned area floor space. The researchers in this study feel this is a conservative estimate given the age of the duct system and the evidence of disconnected duct runs. Correspondingly, the estimated energy savings are likely to be conservative as well.

Table 14. North Carolina recommended package with simulated energy savings from EnergyGauge

\begin{tabular}{|l|l|r|l|l|}
\hline & $\begin{array}{l}\text { Predicted Site } \\
\text { Energy } \\
\text { (MMBtu) }\end{array}$ & $\begin{array}{l}\text { Predicted Source } \\
\text { Energy (MMBtu) }\end{array}$ & $\begin{array}{l}\text { Site Energy } \\
\text { Savings (\% per } \\
\text { measure) }\end{array}$ & $\begin{array}{l}\text { Source Energy } \\
\text { Savings (\% per } \\
\text { measure) }\end{array}$ \\
\hline $\begin{array}{l}\text { North Carolina } \\
\text { Simulated Energy } \\
\text { Use }\end{array}$ & 245 & 478 & & \\
\hline $\begin{array}{l}\text { + Envelope } \\
\text { Improvements }\end{array}$ & 189 & 394 & $23 \%$ & $18 \%$ \\
\hline $\begin{array}{l}++ \text { HVAC System } \\
\text { Improvements }\end{array}$ & 148 & 301 & $17 \%$ & $20 \%$ \\
\hline
\end{tabular}


+++ Water Heater

Improvements

Total Retrofit

Investment
134

298

$6 \%$

$1 \%$

$45 \%$

$38 \%$

As can be seen in Figure 34, the energy savings for the primary building loads are significant. The heating and cooling load energy savings are $51 \%$ and $56 \%$, respectively.

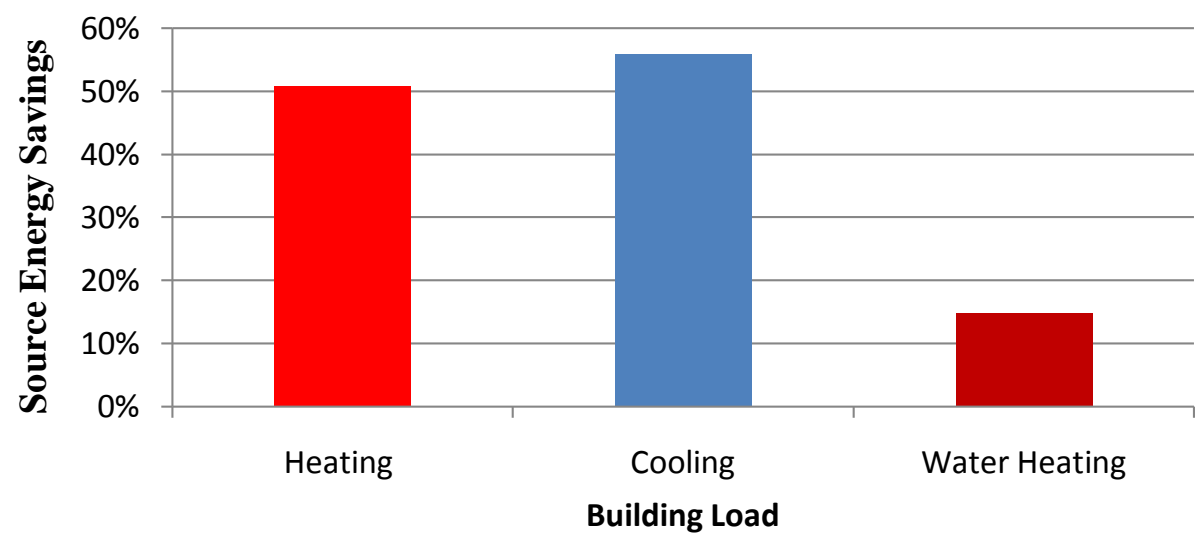

Figure 34. Simulated Energy Savings from Heating and Cooling Loads

\section{Diagnostics and Test Out}

When scheduling with subcontractors permitted, Blower Door tests were done at intervals to investigate the effectiveness of individual retrofit measures. The results are shown in Table 15 in the order in which the tests were done. Conducting successive diagnostic Blower Door tests can yield valuable information and insight into the impact of individual measures and facilitate more accurate prediction of energy savings. For example, as seen in the table, undergoing air sealing in the crawlspace can yield significant infiltration reductions. A decrease of $2710 \mathrm{CFM}_{50}(25 \%$ of the total building infiltration) was achieved by applying low-density, open-cell spray foam to the crawlspace band joist, and high-density closed-cell spray foam to the foundation wall. Air sealing in the attic also contributed to a significant infiltration reduction of 2,290 $\mathrm{CFM}_{50}(18 \%)$. In total, the infiltration was reduced by approximately $39 \%$. 
Table 15. Pre-retrofit and post-retrofit air infiltration diagnostics

\begin{tabular}{|l|l|l|}
\hline Retrofit Measure Tested & \begin{tabular}{l} 
Blower Door Test Result $_{\left(\mathbf{C F M}_{\mathbf{5 0}} / \mathbf{A C H}_{\mathbf{5 0}}\right)}$ \\
\hline Initial
\end{tabular} & Percent Reduction $^{\mathbf{2 0}}$ \\
\hline $\begin{array}{l}\text { Attic Sealing on Ceiling Plane+ } \\
\text { Knee walls Sealed with Open- } \\
\text { Cell Foam+ Typical Air Sealing } \\
\text { Measures }\end{array}$ & $10,400 / 16.9$ & $18 \%$ \\
\hline $\begin{array}{l}\text { Crawlspace Band Sealed with } \\
\text { Open-Cell Foam }\end{array}$ & $9,651 / 15.7$ & $7 \%$ \\
\hline $\begin{array}{l}\text { Foundation Wall Sealed with } \\
\text { Closed-Cell Foam }\end{array}$ & $7,688 / 12.8$ & $18 \%$ \\
\hline Final & $7,688 / 12.8$ & $39 \%$ \\
\hline
\end{tabular}

The impact of replacing the ducts is shown in Table 16. Whereas initially, the substantial duct leakage to the outside of the building envelope was such that the ducts could not be pressurized to permit measurement, after the retrofit, there is only $103 \mathrm{CFM}_{25}$ of leakage in the system that provides conditioning to the first floor and $43 \mathrm{CFM}_{25}$ of leakage in the second floor unit. The large improvement was facilitated by the fact that all of the ducts that provide conditioned air to the first floor were replaced with new ducts that were installed with specific attention given to minimizing leakage.

Table 16. Duct Blaster tests results - duct leakage to outside measured as air flow at $25 \mathrm{~Pa}\left(\mathrm{CFM}_{25}\right)$ and normalized as a percentage $\left(\mathrm{CFM}_{25} /\right.$ conditioned area $\left.\left(\mathrm{ft}^{2}\right)\right)$

\begin{tabular}{|c|c|c|c|c|}
\hline & \multicolumn{2}{|c|}{$\begin{array}{c}\text { System 1* } \\
\text { (second floor) }\end{array}$} & \multicolumn{2}{|c|}{$\begin{array}{c}\text { System 2** } \\
\text { (first floor) }\end{array}$} \\
\hline & CFM $_{25}$ & \% Leakage to Outside & CFM $_{25}$ & \% Leakage to Outside \\
\hline Initial & 283 & $22 \%$ & \multicolumn{2}{|c|}{ Could not pressurize } \\
\hline Post & 43 & $3 \%$ & 103 & $4 \%$ \\
\hline \% Reduction & $85 \%$ & $85 \%$ & $\%$ & $\%$ \\
\hline
\end{tabular}

* The conditioned area is equal to $1,300 \mathrm{ft}^{2}$.

** The conditioned area is equal to $2,410 \mathrm{ft}^{2}$.

\footnotetext{
${ }^{20}$ Percent reduction is determined by evaluating the $\mathrm{cfm} 50$ reduction for each of the retrofit measures as a ratio of the total building infiltration.
} 
Overall the final HERS index improved from 160 to 90, which reflects the significant energy savings that are predicted for this retrofit. In FY12, whole-house energy consumption, along with the contribution of major loads such as the air conditioner, will be submetered by an eMonitor device installed in May 2011. Additionally, utility bills will continue to be collected for comparison with pre-retrofit utility bills.

\section{North Carolina Cost and Scope of Work}

The retrofit measures described in this report were completed in August 2011, at a total cost of about $\$ 35,750$. Table 17 provides a summary of the final scope of work and breakdown of the costs.

Table 17. North Carolina final scope of work and costs.

\begin{tabular}{|c|c|c|c|}
\hline Home Characteristics & Existing Conditions & Measures & Final Costs \\
\hline $\begin{array}{c}\text { Attic/ } \\
\text { Knee walls }\end{array}$ & $\begin{array}{c}\text { R-11 blown fiberglass/ } \\
\text { R-0 }\end{array}$ & $\begin{array}{c}\text { R-38 blown fiberglass } \\
\text { and other air sealing } \\
\text { measures / } \\
\text { R-15 open-cell foam }\end{array}$ & $\$ 8,650$ \\
\hline Foundation & $\begin{array}{l}\text { R-13 fiberglass batts in } \\
\text { the subfloor }\end{array}$ & N/A & N/A \\
\hline Foundation Walls & $\mathrm{R}-0$ & $\begin{array}{l}\text { R-13 (closed-cell foam } \\
\text { on walls), } \\
\text { R-11 (open-cell foam on } \\
\text { band), } \\
\text { New vapor barrier }\end{array}$ & $\$ 7,970$ \\
\hline \multirow{2}{*}{ Cooling } & $\begin{array}{l}3.5 \text { ton, } 9 \text { SEER (first } \\
\text { floor) }\end{array}$ & $\begin{array}{l}4 \text { ton, } 16 \text { SEER (first } \\
\text { floor) }\end{array}$ & \multirow{2}{*}{$\$ 14,750$} \\
\hline & $\begin{array}{l}2.5 \text { ton, 9.5 SEER } \\
\text { (second floor) }\end{array}$ & $\begin{array}{l}2.5 \text { ton, } 16 \text { SEER } \\
\text { (second floor) }\end{array}$ & \\
\hline \multirow{2}{*}{ Heating } & $\begin{array}{l}125 \text { kBtuh } 91 \text { AFUE } \\
\text { (first floor) }\end{array}$ & N/A & \\
\hline & $\begin{array}{c}\text { 50kBtuh 91 AFUE } \\
\text { (second floor) }\end{array}$ & N/A & \\
\hline DHW & $.59 \mathrm{EF}$ & $\begin{array}{c}50 \text { gal. } 2.0 \text { EF Rheem } \\
\text { Heat Pump Water } \\
\text { Heater }\end{array}$ & $\$ 4,380$ \\
\hline
\end{tabular}




\section{Virginia}

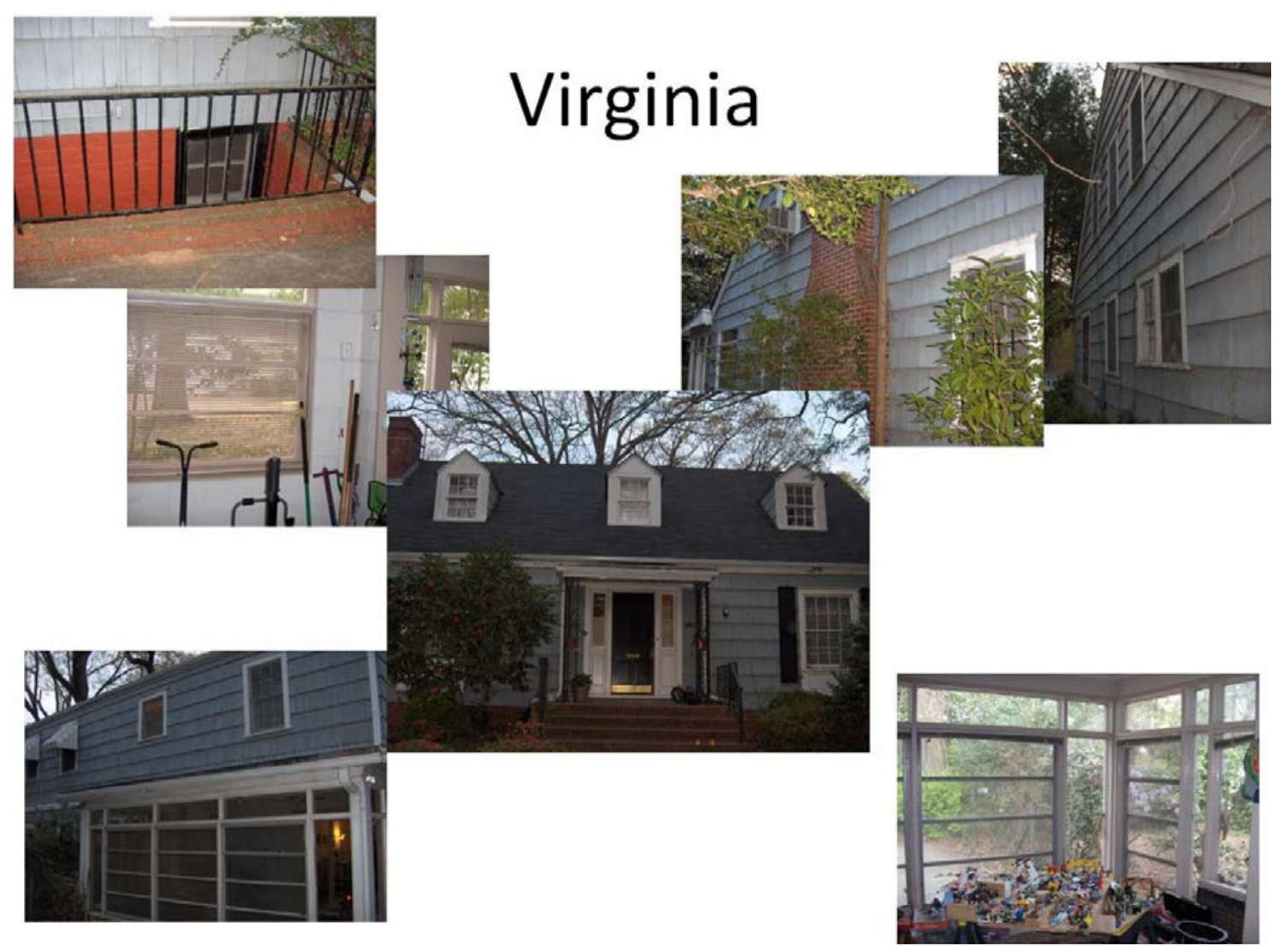

\section{Virginia Home Profile}

Originally built in the 1920s, Virginia is a two-story, single-family detached home with 2,920 $\mathrm{ft}^{2}$ of living area. The first floor has a living area of $1,670 \mathrm{ft}^{2}$, while the second floor has 1,250 $\mathrm{ft}^{2}$. Virginia is home to a family of two adults and two children. There are three bedrooms and two bathrooms. Virginia has a traditional vented attic and a vented crawlspace.

The tenants have lived in the home for about 4 years. The utility bills for this home are shown in Figure 35. Even though the husband operates a home-based business, with a total utility bill of $\$ 2260$ (127 MMBtu of site energy) from February 2010 - January 2011, Virginia uses slightly less than an average home in the southeast of similar size ${ }^{21}$. When the energy use is viewed in light of the building age, HVAC efficiency, air leakage in the envelope, and limited building insulation, the consumption is unexpectedly low. However, discussion with the building tenants yielded insight into the discrepancy between expected and actual building energy consumption. Because energy conservation is a high priority for this family, when the home is occupied during

\footnotetext{
${ }^{21}$ Per the 2010 Buildings Energy Data Book, energy consumption for the South Atlantic region is $47.4 \mathrm{kBtu}$ per square foot. A similar home of this size would have an average annual energy consumption of $140 \mathrm{MMBtu}$.
} 
the day, the family primarily locates in one room in the house. Much attention is paid to ensuring that all other rooms in the home are "electrically unplugged" when no one is there.

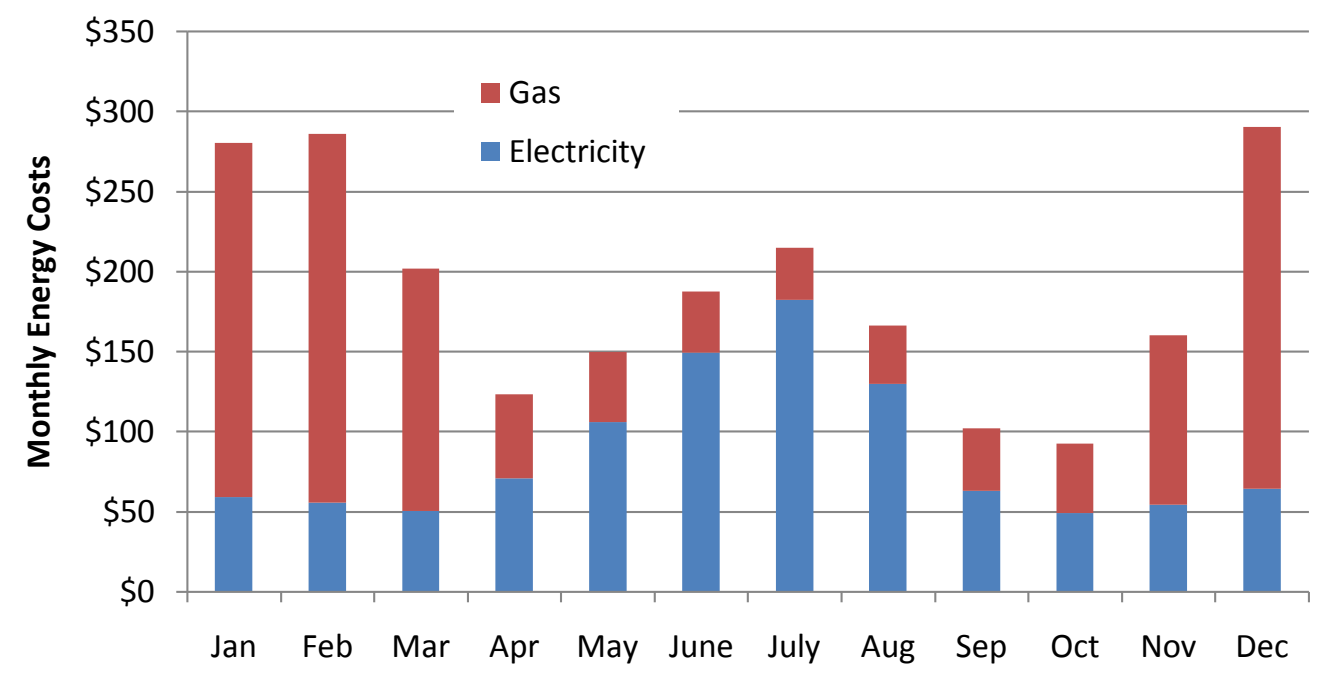

Figure 35. Virginia Monthly Energy Costs

In order to reduce energy consumption from space conditioning, the family relies heavily on temperature setbacks as shown in Table 18. The tenant said that while these set points result in significant energy and costs savings, thermal comfort and convenience are compromised. For example, since the temperature set points in the cooling season are relatively high (i.e. $83^{\circ} \mathrm{F}$ ), it can become quite uncomfortable in some of the bedrooms that are on the second floor. Evidence of the energy saving benefit of their conservative behavior was seen when one of the family members was on sabbatical in another location, thus requiring the family to relocate. During this time, the home was subleased and the utility bills more than doubled.

Table 18. Temperature set points for Virginia

\begin{tabular}{|l|c|l|r|}
\hline \multicolumn{3}{|c|}{ Cooling } & \multicolumn{2}{c|}{ Heating } \\
\hline Time & Temperature set point & Time & Temperature set point \\
\hline 7:30 - 10:00 & (deg F) & & (deg F) \\
\hline $10: 00-18: 00$ & 87 & $6: 30-8: 00$ & 50 \\
\hline $18: 00-22: 00$ & 83 & $8: 00-14: 30$ & 68 \\
\hline $22: 00-7: 30$ & 77 & $14: 30-22: 00$ & 45 \\
\hline
\end{tabular}


VIRGINIA PRE-RETROFIT

\section{CHARACTERISTICS}

TYPE: Two-story, single-family home

SIZE: $2,920 \mathrm{ft}^{2}$

Occupancy: Two adults, two

children

\section{INITIAL ENVELOPE}

\section{PROFILE}

WALL INSULATION: None

BAND INSULATION: None

ATTIC INSULATION: R-0 - R-11

KNEEWALL INSULATION: R-13

INITIAL MECHANICAL

\section{PROFILE}

FIRST FLOOR ZONE

Location: Unconditioned

basement

Cooling: 9 SEER (electric)

Heating: 56 AFUE (natural gas)

WATER HEATER: 0.59 EF

\section{INITIAL DIAGNOSTIC}

\section{RESULTS}

HERS: 230

HESCORE: 1

AIR INFILTRATION:

5,610 CFM $50\left(23 \mathrm{ACH}_{50}\right)$

DUCT LEAKAGE TO OUTSIDE:

Too high to measure

DUCT INSULATION: None

(75\%) and R-6 (25\%)

COMBUSTION SAFETY TEST: All

the units passed. Gas leaks

were detected.

\section{Virginia Initial Characteristics Envelope Profile}

The building envelope is bounded by a framed floor above the vented crawlspace and an insulated ceiling plane above the first and second floors. The interior ceiling height is 8 feet. The home also has a porch with a supply register that provides conditioned air to this area. Therefore the porch is considered a part of the conditioned volume. Shown in Figure 36 is an illustration of the initial envelope profile. The dark green color represents the attic knee walls. As seen in the figure, there is significant attic exposure through knee walls. While the knee walls did have R-13 batts installed, there was no air barrier in place to align the thermal and pressure boundaries. Therefore, the effectiveness of the R-13 insulation was reduced significantly.

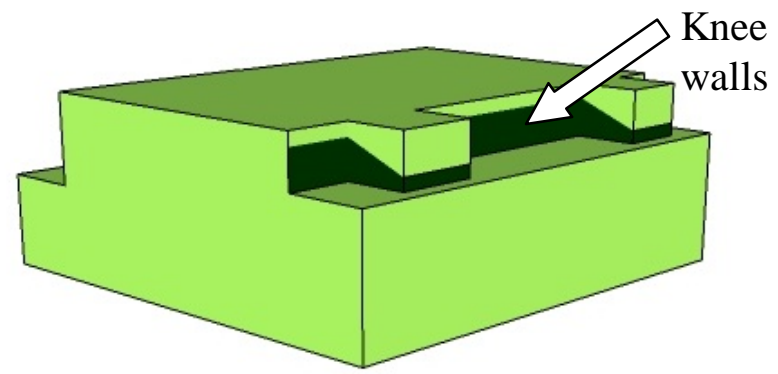

Figure 36. Virginia initial envelope profile

To aid in the building assessment, thermal infrared imaging was done.

The assessment was performed as early in the morning as permitted by the homeowner (around 7:00 a.m.) before the building gained a great amount of solar load from the rising sun. Through the thermal scan and visual inspection of the house, no insulation was evident in exterior walls of the home (Figure 37) 


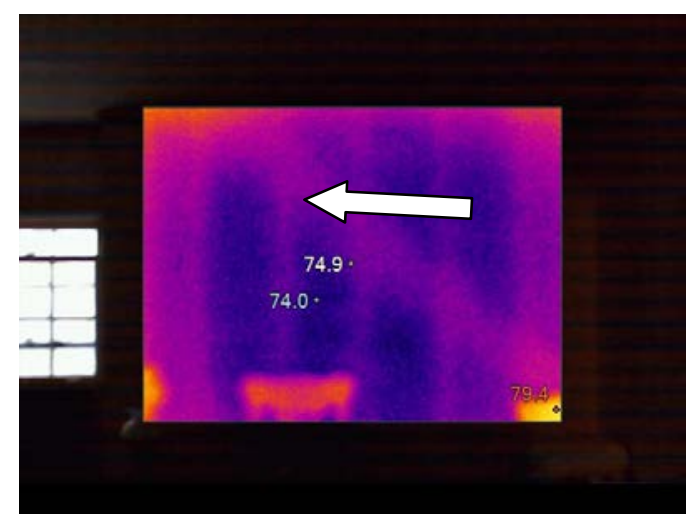

Figure 37. Thermal image of an exterior wall in Virginia. The arrow in the figure highlights the absence of insulation in the wall cavities between the studs.

In the flat ceiling over the first floor, blown fiberglass insulation was present, with a range of coverage equivalent to insulation values up to R-11. Similarly, the blown fiberglass on the ceiling above the second floor ranged in thicknesses equivalent to insulation values up to R-9.

In the ceiling of the crawlspace (i.e. subfloor), there were R-13 fiberglass batts that were recently installed. However, the batts were compressed between the floor joists such that the intended insulation value was reduced. In addition, the batts were installed with the kraft paper side down (i.e. toward the ground and not in contact with the subfloor), which is not consistent with recommended installation practices in the mixed-humid climate zone. In this zone, manufacturers recommend that the faced side of the batts touch the warm winter-time surface (i.e. the subfloor) in order to prevent condensation and moisture problems. A photograph of the R-13 insulation installation is shown in Figure 38. Because the batts are intended for installation in a 3.5” thick cavity, but are installed in a 9.5” thick cavity, there is a significant gap between the batt insulation and the subfloor.

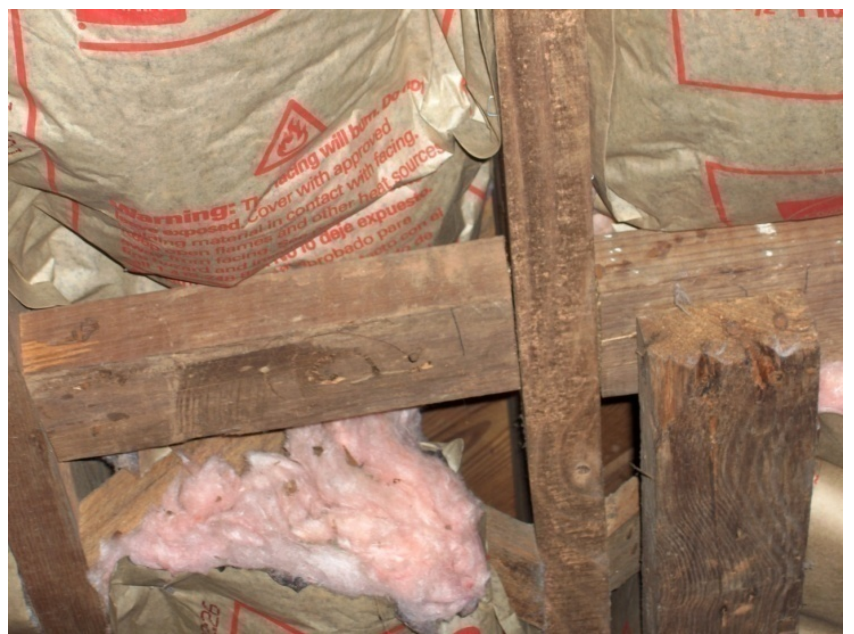

Figure 38. R-13 insulation installed in a manner inconsistent with recommended approaches.

A vapor barrier was present in places on the crawlspace floor, but did not provide full coverage. A consistent coverage on the ground is needed to prevent potential moisture pathways, and 
thereby reduce the risk for mold growth and wood rot. In the areas where the vapor barrier did exist, it was not taped and overlapped to the crawlspace walls and stem walls extending up at least 6" from the ground, as is required by Georgia Energy Code in Section 402.2.922. Further visual inspection of the subfloor identified areas of air infiltration pathways into the conditioned space. These areas were most prevalent around plumbing and electrical penetrations.

The windows in the home are all single pane, with a mixture of metal and wood frames.

The home also has a whole-house fan. However, the tenant stated that it was not used.

During the initial home energy assessment, a Blower Door test was conducted to evaluate the air infiltration. The total air leakage rate was 5,614 $\mathrm{CFM}_{50}$. With a conditioned volume of 23,392 $\mathrm{ft}^{3}$, the air exchange rate for Virginia was approximately $14 \mathrm{ACH}_{50}$.

\section{HVAC}

The HVAC system (including ducts) was located in the crawlspace. A single split system serves the home with a 2.5 ton capacity and an efficiency of 9 SEER. The thermostat that controlled the central air system was located downstairs; therefore, the ability to effectively balance temperatures between the first and second floor was limited. To supplement cooling capacity, window air conditioner units were placed in the master bedroom and the porch. However, these units were not used on a consistent basis. The air conditioner in the porch was only used sparingly, while the air conditioner in the master bedroom was only used at night when temperature and humidity levels became intolerable. For heating, Virginia had a gas furnace with a 150 kBtuh capacity and a rated efficiency of 56 AFUE. The exact age of the gas furnace is unknown, but it is believed that the furnace is approximately 40 years old. With all of the ducts in the crawlspace, the entire HVAC system is located outside of the conditioned envelope. The ducts were poorly sealed as determined by initial diagnostic tests. There were several duct connections that were disconnected (Figure 39) such that pressurizing the ducts to evaluate the overall leakage was not possible.

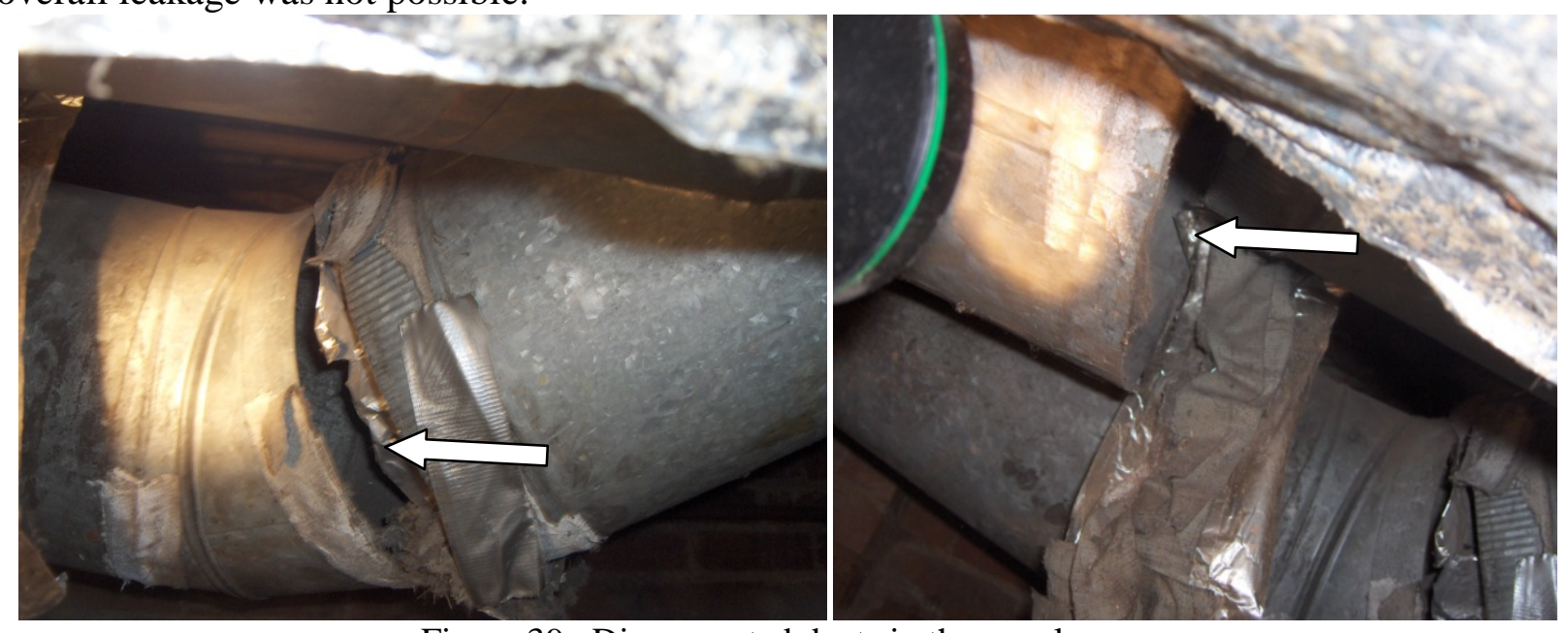

Figure 39. Disconnected ducts in the crawlspace

${ }^{22}$ GA International Energy Conservation Code Supplements and Amendments 2011 


\section{Lighting, Water Heating, Appliances}

The gas water heater is located in the vented crawlspace. It has a storage capacity of 40 gallons and is rated at $0.59 \mathrm{EF}$. The house has 78\% CFL lighting and no ENERGY STAR appliances. Both the range and oven are gas fueled.

\section{Health and Safety}

A thorough combustion safety test was performed on the water heater and furnace, because even though the units are considered to be outside of the envelope, there were major air leakage pathways that connect the area to the living space. Both units passed all components of the combustion safety test: spillage, draft, and CO.

Gas leaks were detected off of the main gas line for the furnace. 


\section{Retrofit Measures}

Using the prioritization protocol for this retrofit study, the following retrofit priorities were determined.

Table 19. Virginia priority list

\begin{tabular}{|l|l|c|}
\hline \multicolumn{1}{|c|}{ Improvement } & \multicolumn{1}{c|}{ Existing condition } & Priority \\
\hline Air sealing & $\sim 0.9 \mathrm{ACH}_{\text {natural }}^{23}$ & $\mathrm{~B}$ \\
\hline Improve ducts & Couldn't pressurize & $\mathrm{A}$ \\
\hline Insulate ATTIC (attic floor air sealing & R-6 & $\mathrm{A}$ \\
must precede insulation work) & $\mathrm{R}-11$ & $\mathrm{~B}$ \\
\hline Insulate ATTIC KNEE WALLS & $\begin{array}{l}\text { Insulated, unsheathed or incomplete } \\
\text { sheathing }\end{array}$ & $\mathrm{B}$ \\
\hline Insulate WALLS & None & $\mathrm{C}$ \\
\hline Insulate FLOOR & Any & $\mathrm{C}$ \\
\hline Insulate BASEMENT/CRAWLSPACE & None & $\mathrm{B}$ \\
WALLS & No radiant barrier & $\mathrm{D}$ \\
\hline Radiant barrier & 56 AFUE & $\mathrm{A}$ \\
\hline Replace heating system & 9.3 SEER & $\mathrm{A}$ \\
\hline Replace cooling system & .58 gas & $\mathrm{D}$ \\
\hline Replace water heater & Gas & $\mathrm{C}$ \\
\hline Insulate water heater and pipe & Wood single-pane \\
\hline Improve windows & Metal single-pane & $\mathrm{B}$ \\
\hline
\end{tabular}

Measures that received a priority of A or B from the prioritization protocol listed in Table 19were used as a basis for discussion with the homeowner and retrofit contractor on determining the final retrofit package. Retrofit measures included in the final package are described in the following text.

\section{Envelope}

As can be seen in the retrofit priority list in Table 19, air sealing and attic insulation were categorized as A or B priorities. As such, the ceiling plane is a primary point of focus in completing these measures. Insulation subcontractors air sealed around the electrical penetrations, can lights, and typical plumbing penetrations. They also used rigid foam board to flash the chase around the chimney. Since the whole-house fan was not used, it was removed and the resulting hole was capped and sealed.

The R-13 batt insulation in the attic knee walls was removed and replaced with a low density, open-cell spray foam. The spray foam provides insulation and air sealing properties to effectively align the thermal and air barriers. All attic accesses were weather-stripped and insulated with R5 Thermax boards. The attic ceilings for both the $1^{\text {st }}$ and $2^{\text {nd }}$ floor were insulated with blown fiberglass to R-38.

\footnotetext{
${ }^{23} \mathrm{ACH}_{\text {natural }}=\mathrm{ACH}_{50} / \mathrm{N}_{\text {corrected, }}$, where $\mathrm{N}_{\text {corrected }}$ is the height-corrected LBL "N-factor" (http://www.bpi.org/Web\%20Download/BPI\%20Standards/Building\%20Analyst\%20Professional_2-28-05nNCnewCO.pdf)
} 
The existing fiberglass batts in the subfloor were removed so that penetrations through the subfloor could be sealed. The batts were reinstalled with the faced side against the floor (Figure 40) to be consistent with recommended best practices to mitigate risks associated with moisture and condensation. The crawlspace band was also sealed with open-cell spray foam as can also be seen in the figure.

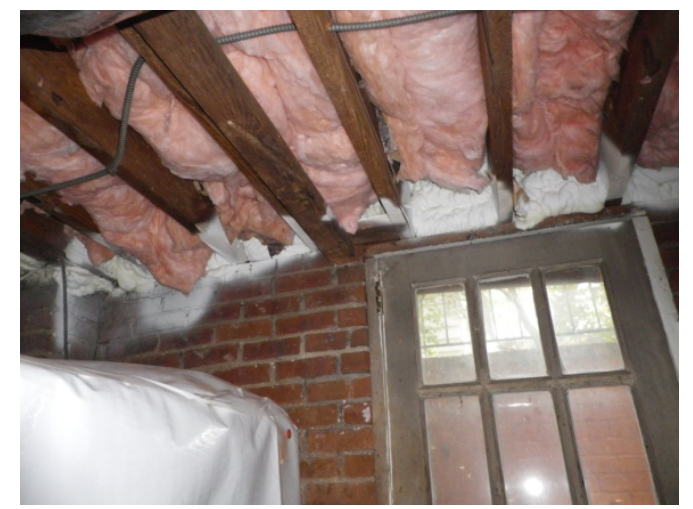

Figure 40. Fiberglass batts reinstalled in the crawlspace after air sealing

Since the porch was not used as a "living space" by the tenants, the supply registers were capped. By removing the supply from the porch, the building envelope area and volume were reduced by $140 \mathrm{ft}^{2}$ and $1,120 \mathrm{ft}^{3}$, respectively.

\section{HVAC}

The original HVAC system was removed and replaced with consideration given for the building performance and capability to maintain comfortable temperature and humidity levels. A Manual $\mathrm{J}$ calculation was completed on the home based on the estimated impact of the planned retrofit measures. Based on the Manual J calculation, it was determined that a 2.5 ton capacity air conditioner would not be sufficient to meet the entire building cooling load. The contractor and building owner agreed to separate the building into four zones. The first floor would comprise one zone, while each bedroom upstairs would be zoned separately. A 2 ton capacity, ENERGY STAR 14.5 SEER air conditioning unit, and a $90 \mathrm{kBtuh}, 95$ AFUE sealed-combustion gas furnace were installed in the crawlspace to provide conditioning to the first floor. The second floor zones are provided conditioning through a 19.2 SEER, 10 HSPF mini-split heat pump system. The indoor unit in the master bedroom has a cooling capacity of 1.5 tons, while the other two bedrooms have indoor units with a cooling capacity of 1 ton. A photograph of one of the indoor mini-split units is shown in Figure 41. Also shown in the figure is an outdoor refrigerant line for one of the indoor units. 


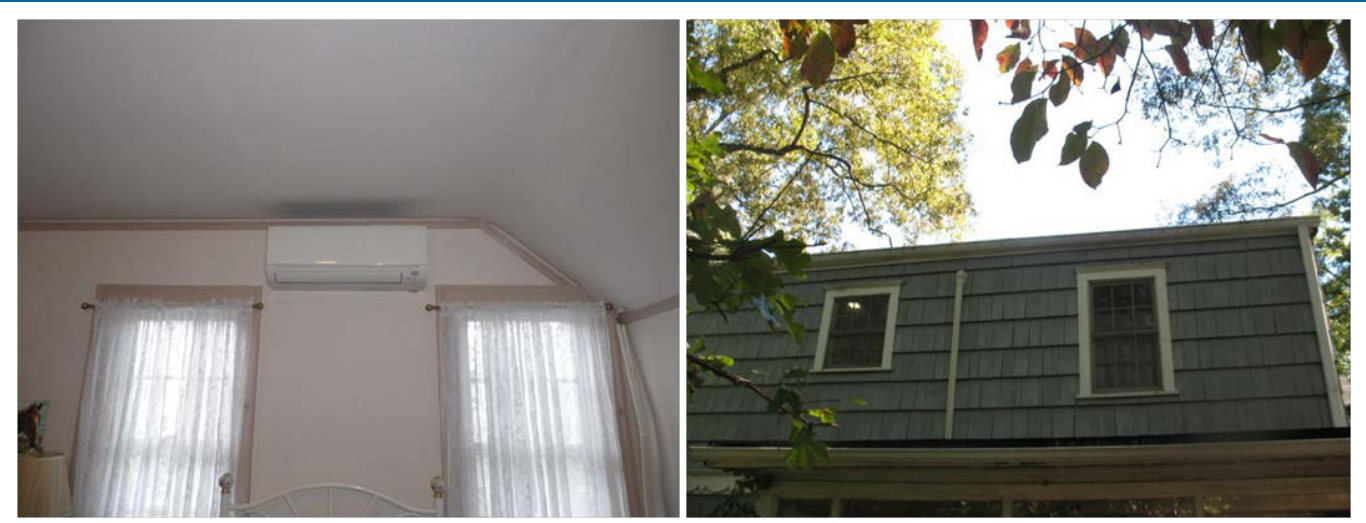

Figure 41. Photograph of the min-split system in Virginia. Indoor unit is shown in the image on the left. The outdoor refrigerant lines are shown in the image on the right.

The family that currently lives in Virginia has a lifestyle that is very conducive to the zoning strategy employed in the building retrofit, since the family spends daytime hours on the first floor and nighttime hours on the second floor. Replacing the singular central air system with two systems also eliminates the need to use ducts that travel through the interior wall from the crawlspace to the second floor bedrooms. As previously discussed, during the initial energy assessment, the ducts were too leaky to pressurize to determine a duct leakage value. While replacing the duct system that served the first floor would have surely improved the duct leakage, it would not have been possible to seal and/or replace the ducts that were in the interior walls using traditional duct sealing methods. More advanced approaches such as Aeroseal duct sealing could have been employed in this house. However, installing the mini-split system gave the opportunity to provide more localized control of the thermal environment, install equipment with a higher HVAC efficiency, and eliminate ducts that would have otherwise been sub-optimally located.

Two windows that needed repair were replaced.

\section{Lighting, Water Heating, Appliances}

The water heater was not upgraded. No lighting or appliance upgrades were made.

\section{Health and Safety}

Combustion safety issues were addressed in atmospherically vented water heater. Since the gas furnace was replaced with a sealed-combustion furnace, combustion safety risks were mitigated. The gas lines that were leaking previously were replaced.

\section{Simulated Energy Savings}

Table 20 shows the simulated energy savings from the implemented retrofit measures. In total, there is an estimated 34\% reduction in source energy consumption. Due to the significant amount of duct leakage in the pre-retrofit case, coupled with the poor efficiency of the air conditioning unit, the largest energy savings are projected to be due to improvements in the HVAC system. Because the ducts could not be pressurized initially, it was difficult to accurately predict the energy savings due to duct improvements in our modeling. For modeling purposes, we estimated an initial duct leakage of approximately $1000 \mathrm{CFM}_{25}$. This is equivalent to about 
$35 \%$ of the conditioned area floor space. The researchers in this study feel this is a conservative estimate given the age of the duct system and the evidence of disconnected duct runs.

Correspondingly, the estimated energy savings are likely to be conservative as well.

Table 20. Virginia recommended package with simulated energy savings from EnergyGauge

\begin{tabular}{|l|r|r|r|r|}
\hline & \multicolumn{1}{|c|}{$\begin{array}{c}\text { Predicted } \\
\text { Site } \\
\text { Energy } \\
\text { (MMBtu) }\end{array}$} & $\begin{array}{c}\text { Predicted } \\
\text { Source } \\
\text { Energy } \\
\text { (MMBtu) }\end{array}$ & $\begin{array}{c}\text { Site } \\
\text { Energy Savings } \\
\text { (\% per measure) }\end{array}$ & $\begin{array}{c}\text { Source } \\
\text { Energy Savings } \\
\text { (\% per measure) }\end{array}$ \\
\hline $\begin{array}{l}\text { Virginia Simulated } \\
\text { Energy Use }\end{array}$ & 153 & 250 & & \\
\hline $\begin{array}{l}+\quad \text { Envelope } \\
\text { Improvements }\end{array}$ & 136 & 226 & $11 \%$ & $10 \%$ \\
\hline $\begin{array}{l}++ \text { HVAC System } \\
\text { Improvements }\end{array}$ & 87 & 166 & $32 \%$ & $24 \%$ \\
\hline Total Retrofit Investment & & & $43 \%$ & $34 \%$ \\
\hline
\end{tabular}

As can be seen in Figure 34, the energy savings for the primary building loads are significant. The heating and cooling load energy savings are $62 \%$ and 55\%, respectively.

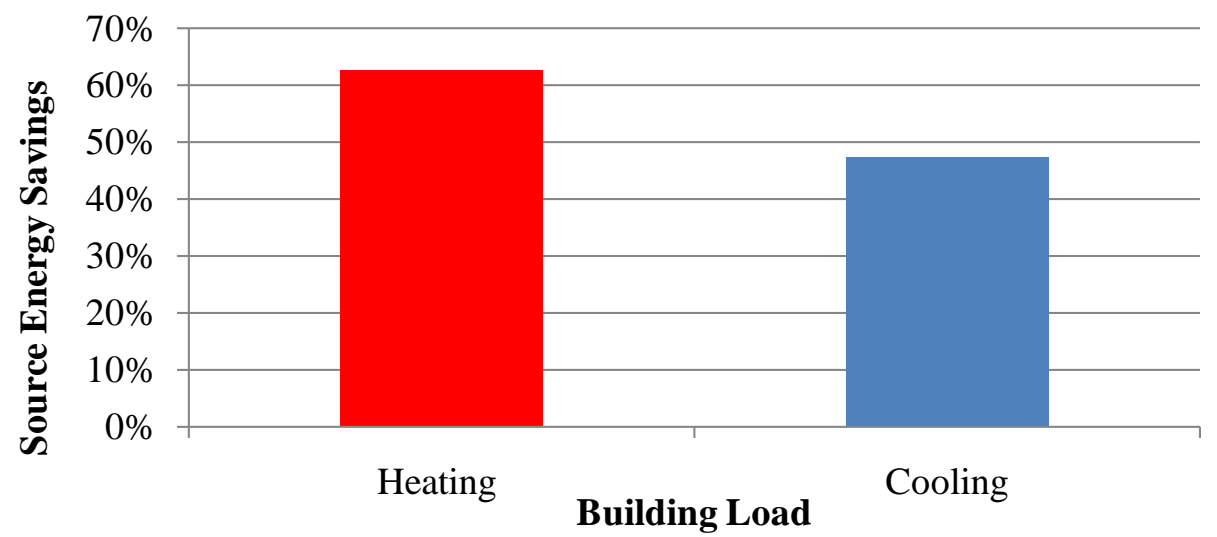

Figure 42. Simulated Energy Savings from Heating and Cooling Loads

\section{Diagnostics and Test Out}

When scheduling with subcontractors permitted, Blower Door tests were done at intervals to investigate the effectiveness of individual retrofit measures. The results are shown in Table 21 in the order in which the tests were done. Conducting successive diagnostic Blower Door tests can yield valuable information and insight into the impact of individual measures and facilitate more accurate prediction of energy savings. For example, as seen in the table, undergoing air sealing in the crawlspace can yield significant infiltration reductions. A decrease of $1,180 \mathrm{CFM}_{50}(21 \%$ of the total building infiltration) was achieved by applying low-density, open-cell spray foam to the crawlspace band joist in addition to "spot sealing” bypasses in the subfloor such as plumbing and electrical penetrations. While only two windows were replaced in this retrofit, the reduction in infiltration was approximately $490 \mathrm{CFM}_{50}$ (9\%). In total, the infiltration was reduced by approximately $44 \%$. 
Table 21. Pre-retrofit and post-retrofit air infiltration diagnostics

\begin{tabular}{|c|c|c|}
\hline Retrofit Measure Tested & $\begin{array}{c}\text { Blower Door Test Result } \\
\left(\mathrm{CFM}_{50} / \mathrm{ACH}_{50}\right) \\
\end{array}$ & Percent Reduction $^{24}$ \\
\hline Initial & $5,610 / 14.4$ & \\
\hline $\begin{array}{l}\text { Attic sealing (ceiling plane and } \\
\text { knee walls) }\end{array}$ & $4,810 / 12.3$ & $14 \%$ \\
\hline $\begin{array}{l}\text { Crawlspace sealing (subfloor } \\
\text { and band joist) }\end{array}$ & 3,630 / 9.3 & $21 \%$ \\
\hline Windows replaced (x2) & $3,140 / 8.0$ & $9 \%$ \\
\hline Final & $3,140 / 8.0$ & $44 \%$ \\
\hline
\end{tabular}

The impact of replacing the ducts is shown in Table 22. Whereas initially, the substantial duct leakage to the outside of the building envelope was such that the ducts could not be pressurized to permit measurement, after the retrofit, there is only $98 \mathrm{CFM}_{25}$ of leakage. The large improvement was facilitated by the fact that all of the ducts that provide conditioned air to the first floor were replaced with new ducts that were installed with specific attention given to minimizing leakage. For the second floor space conditioning, all ducts were eliminated with the installation of a high efficiency ductless mini-split system.

Table 22. Pre-retrofit and post-retrofit duct leakage diagnostics - duct leakage to outside measured as air flow at $25 \mathrm{~Pa}\left(\mathrm{CFM}_{25}\right)$ and normalized as a percentage $\left(\mathrm{CFM}_{25} /\right.$ conditioned area $\left.\left(\mathrm{ft}^{2}\right)\right)$

\begin{tabular}{|l|l|l|}
\hline & CFM $_{25}$ & \% Leakage to Outside* \\
\hline Pre-Retrofit & Could not pressurize & Could not pressurize \\
\hline Post-Retrofit & 98 & $6 \%$ \\
\hline
\end{tabular}

* The conditioned area is equal to $1,670 \mathrm{ft}^{2}$.

Overall the final HERS index improved from 230 to 90, which reflects the significant energy savings that are predicted for this retrofit. In FY12, whole-house energy consumption, along with the contribution of major loads such as the air conditioner, will be submetered by an eMonitor device installed in May 2011. Additionally, utility bills will continue to be collected for comparison with pre-retrofit utility bills.

\footnotetext{
${ }^{24}$ Percent reduction is determined by evaluating the cfm50 reduction for each of the retrofit measures as a ratio of the total building infiltration.
} 


\section{Virginia Cost and Scope of Work}

The retrofit measures described in this report were completed in August 2011, at a total cost of about $\$ 37,700$.Table 23 provides a summary of the final scope of work and breakdown of the costs.

Table 23. Virginia final scope of work and costs.

\begin{tabular}{|c|c|c|c|}
\hline Home Characteristics & Existing Conditions & Measures & Proposed Costs \\
\hline Exterior Walls & $\mathrm{R}-0$ & N/A & N/A \\
\hline $\begin{array}{c}\text { Attic/ } \\
\text { Knee walls }\end{array}$ & $\begin{array}{l}\text { R-11 blown fiberglass/ } \\
\text { R-13 fiberglass batts }\end{array}$ & $\begin{array}{c}\text { R-38 blown fiberglass/ } \\
\text { R-15 open-cell foam }\end{array}$ & $\$ 7,590$ \\
\hline Foundation & $\begin{array}{l}\text { R-13 fiberglass batts in } \\
\text { the subfloor }\end{array}$ & $\begin{array}{c}\text { Air-sealing and } \\
\text { reinstall existing R-13 } \\
\text { batts to have paper-side } \\
\text { facing subfloor; } \\
\text { R-11 insulation added to } \\
\text { crawlspace band; new } \\
\text { vapor barrier applied }\end{array}$ & $\$ 3,550$ \\
\hline Foundation Walls & $\mathrm{R}-0$ & N/A & N/A \\
\hline \multirow{2}{*}{ Cooling } & \multirow{2}{*}{2.5 ton, 9 SEER } & $\begin{array}{l}2 \text { ton, 14.5 SEER (first } \\
\text { floor) }\end{array}$ & \multirow{3}{*}{$\begin{array}{l}\left.\$ 11,340 \text { ( }^{\text {st }} \text { floor }\right)^{*} \\
\left.\$ 10,680 \text { ( }^{\text {nd }} \text { floor }\right)\end{array}$} \\
\hline & & $\begin{array}{l}3 \text { ton, 19.2 SEER mini- } \\
\text { split (second floor) }\end{array}$ & \\
\hline Heating & 150 kBtuh, 56 AFUE & 90 kBtuh, 95 AFUE & \\
\hline DHW & $.59 \mathrm{EF}$ & N/A & N/A \\
\hline Windows & $\begin{array}{l}\text { Single-pane wood; } \\
\text { Single-pane metal }\end{array}$ & $\begin{array}{l}\text { Two east-facing (front) } \\
\text { windows replaced with } \\
\text { ENERGY STAR } \\
\text { double-pane; U=.21; } \\
\text { SHGC=.30 }\end{array}$ & $\$ 4,540$ \\
\hline
\end{tabular}

* HVAC costs for the $1^{\text {st }}$ floor includes the installation of new ducts. 


\section{South Carolina}

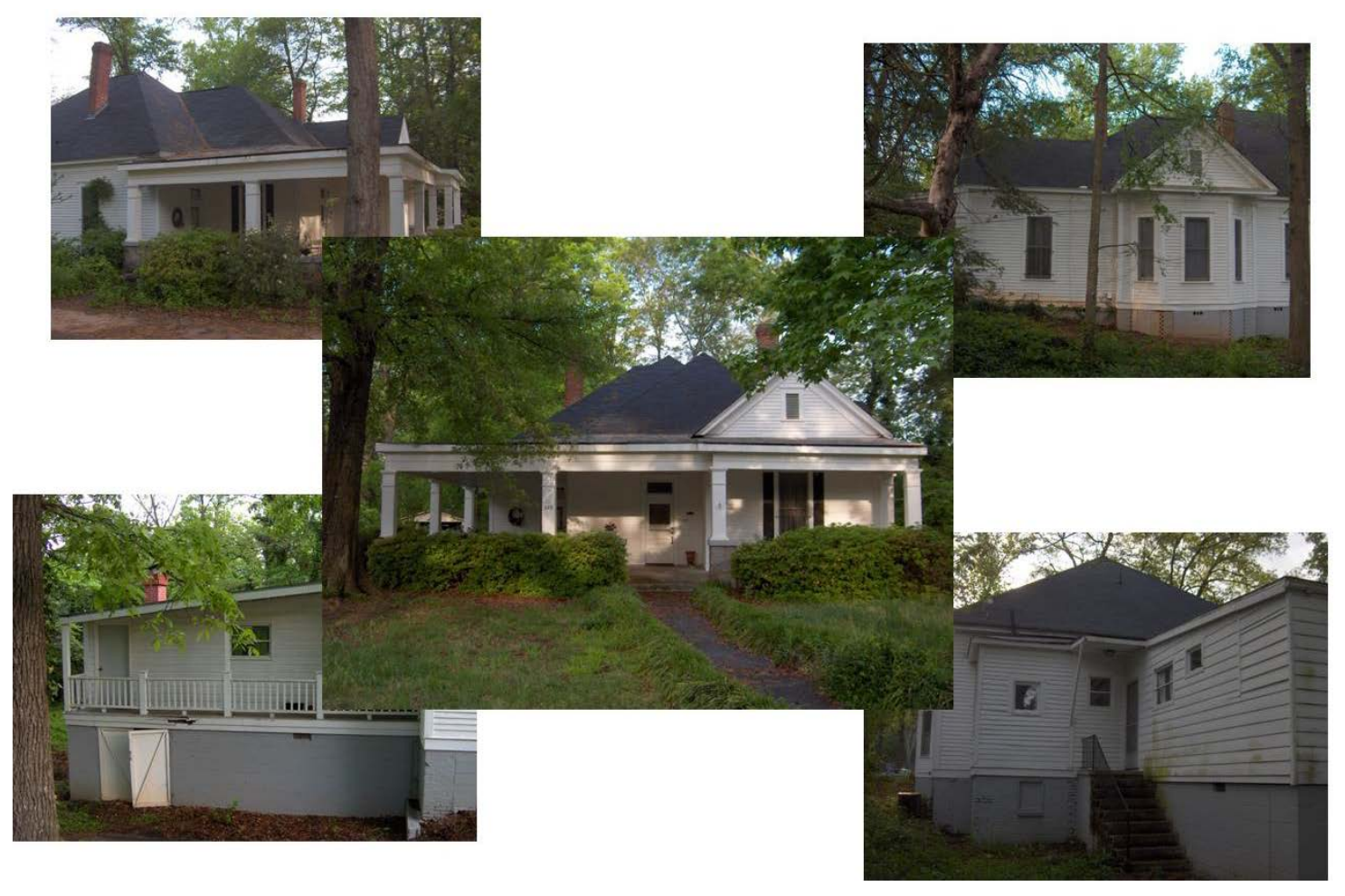

\section{South Carolina Home Profile}

Originally built in the 1920s, South Carolina is a single story, single-family detached home with $2,990 \mathrm{ft}^{2}$ of living area. The home had an addition $\left(340 \mathrm{ft}^{2}\right)$ built onto to the original structure, but the year it was added is not known. In total, there are six bedrooms and three bathrooms in this home. South Carolina has a traditional vented attic and a vented crawlspace.

South Carolina currently serves as the home for five current and past students of a local college. Because South Carolina is home to current and former students, there is an annual turnover in residents when students find other housing or graduate from the college and new students arrive. Even with this in mind, there are usually 5 students that live in the house throughout the year. However, since there is an annual turnover in occupancy, it was not possible for a year of preretrofit utility bills to be collected at the time of this report. Efforts are ongoing to obtain utility bills to enable utility bill analysis of pre- and post-retrofit energy consumption. Nevertheless, based on the Buildings Energy Data Book ${ }^{25}$, the average site energy consumption for a home with this square footage is approximately $142 \mathrm{MMBtu}$.

\footnotetext{
${ }^{25}$ Per the 2010 Buildings Energy Data Book, energy consumption for the South Atlantic region is 47.4 kBtu per square foot.
} 


\section{South Carolina Initial Characteristics Envelope Profile}

The building envelope is bounded by a framed floor above the vented crawlspace and an insulated ceiling plane above the first floor. Figure 43 below provides a 3-D visual of the home, illustrating the initial envelope profile. The addition and main sections of the house are identified in the figure.

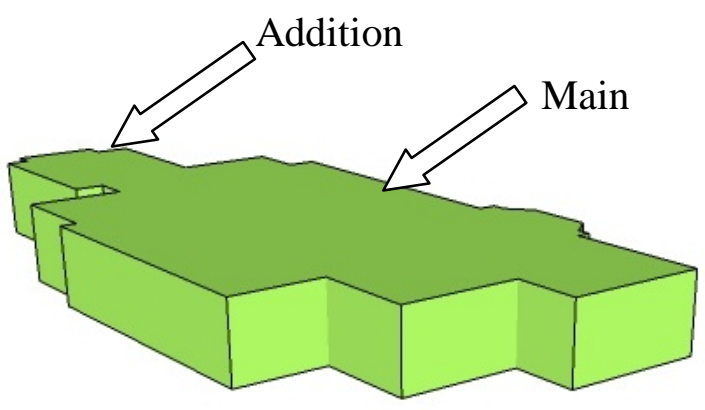

Figure 43. South Carolina initial envelope profile

The interior walls are all 9 feet in height. However, after inspecting the attic, evidence that the interior wall height had been modified from an original height of 11 feet could be seen. Shown in Figure 44 is a photograph taken in the attic that illustrates how the existing interior walls were modified from their original height to their current height.

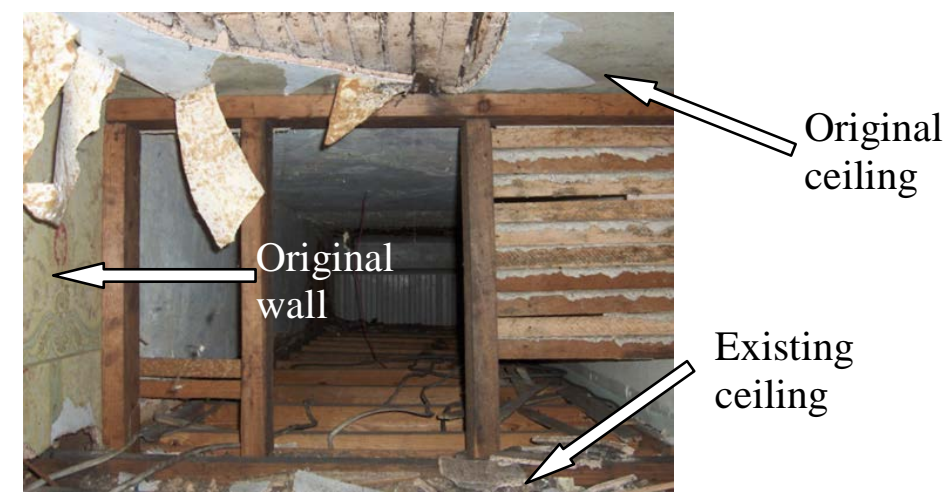

Figure 44. Photograph of the modified ceiling plane in the attic

To aid in the building assessment, thermal infrared imaging was done. The assessment was performed as early in the morning as permitted by the homeowner (around 7:00 a.m.) before the building gained a great amount of solar load from the rising sun. Through the thermal scan and visual inspection of the house, no insulation was evident in exterior walls of the main building (Figure 45). However, a similar thermal scan and visual inspection on the addition provided evidence of cavity insulation (Figure 46). R-11 fiberglass batts were assumed to be present. While batts were present in the walls and ceiling of the addition, areas of missing insulation can clearly be identified in the thermal scan. 


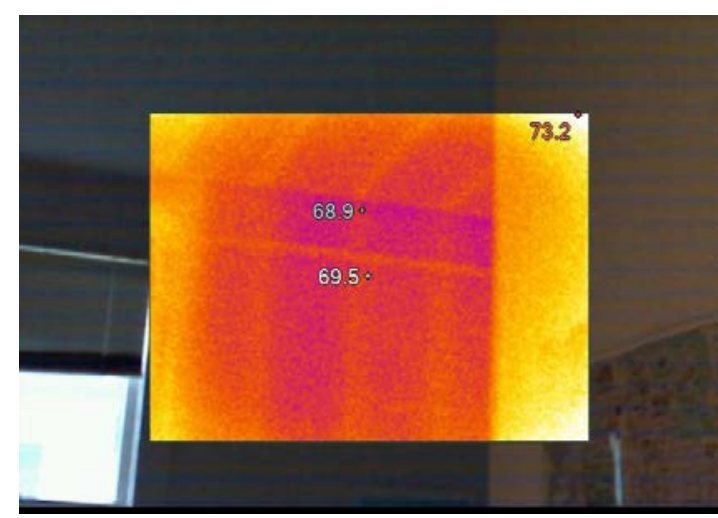

Figure 45. Thermal image of exterior walls in the main section of the home

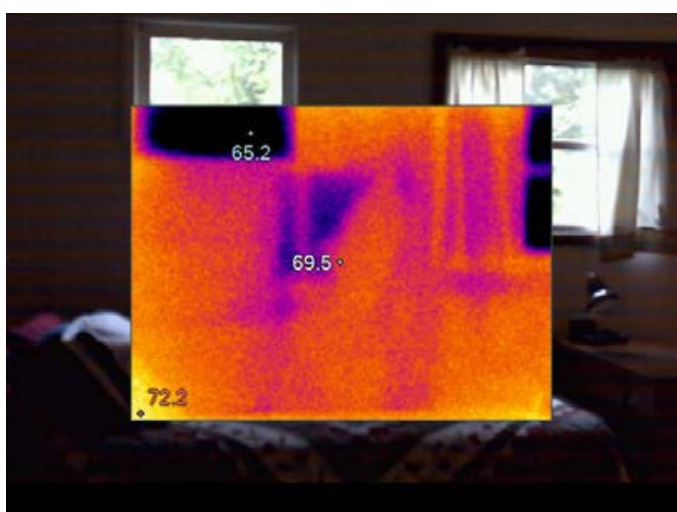

Figure 46. Thermal image of the exterior wall in the addition to the home. The arrow in the figure is shown to highlight insulation voids in the cavities.

In the flat ceiling over the main part of the house blown fiberglass insulation was present with a coverage equivalent to an insulation value of approximately R-11. The ceiling above the addition had R-19 fiberglass batts installed. However, as seen in Figure 47, there were many breaks in the alignment of the thermal and pressure boundary that severely limited the effective resistance to heating and cooling energy losses.

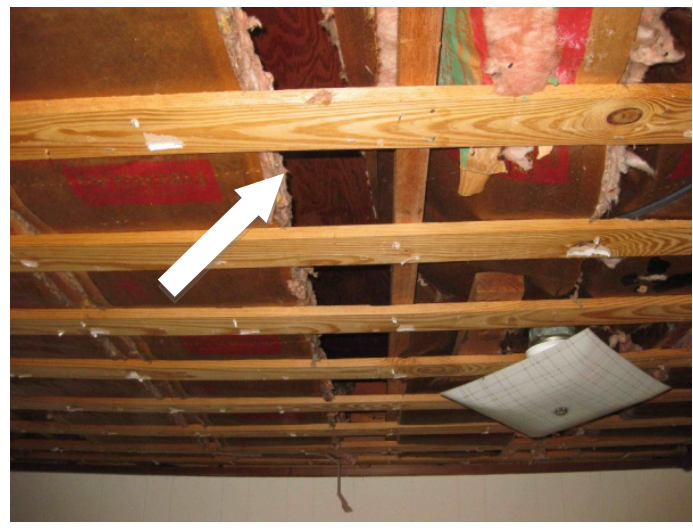

Figure 47. Ceiling insulation in the addition of South Carolina. The arrow in the figure highlights gaps in the insulation where the ceiling was not insulated from the attic air.

In the ceiling of the crawlspace (i.e. subfloor), there were R-13 fiberglass batts that were recently installed. However, the batts were compressed between the floor joists such that the intended R13 insulation value was reduced. In addition, the batts were installed with the kraft paper side down (i.e. toward the ground and not in contact with the subfloor), which is not consistent with recommended installation practices in the mixed-humid climate zone. In this zone, manufacturers recommend that the faced side of the batts touch the warm winter-time surface (i.e. the subfloor) in order to prevent condensation and moisture problems. 
SOUTH CAROLINA PRE-

RETROFIT

CHARACTERISTICS

TYPE: Single story, single-

family home

SIZE: $2,990 \mathrm{ft}^{2}$

Occupancy: Five adults

\section{INITIAL ENVELOPE}

\section{PROFILE}

WALL INSULATION: NONE

BAND INSULATION: None

ATTIC INSULATION: R-11 - R-

19

\section{INITIAL MECHANICAL}

\section{PROFILE}

Location: Vented Crawlspace

Cooling: 9 SEER (electric)

Heating: 80 AFUE (natural

gas)

WATER HEATER: 0.57 EF

\section{INITIAL DIAGNOSTIC}

\section{RESULTS}

HERS: 183

HESCORE: 1

AIR INFILTRATION:

$10,464 \mathrm{CFM}_{50}\left(23 \mathrm{ACH}_{50}\right)$

DUCT LEAKAGE TO OUTSIDE:

$1,254 \mathrm{CFM}_{25}$

DUCT INSULATION: R-0

COMBUSTION SAFETY TEST: All

the units passed. Gas leaks

were detected.
A vapor barrier was present in limited places on the crawlspace floor and only provided minimal coverage. A consistent coverage on the ground is needed to prevent potential moisture pathways, and thereby reduce the risk for mold growth and wood rot. In the areas where the vapor barrier did exist, it was not taped and overlapped to the crawlspace walls and stem walls extending up at least 6 " from the ground, as is required by Georgia Energy Code in Section 402.2.9 ${ }^{26}$. Further visual inspection of the subfloor identified areas of air infiltration pathways into the conditioned space. These areas were most prevalent around plumbing and electrical penetrations.

The windows in the main part of the home were all single pane with wood frames. Similarly, in the addition of the home, the windows were also single pane but had metal frames.

During the initial home energy assessment, a Blower Door test was conducted to evaluate the air infiltration. The total air leakage rate was $10,464 \mathrm{CFM}_{50}$. With a conditioned volume of $26,901 \mathrm{ft}^{3}$ the air exchange rate for South Carolina was approximately $23 \mathrm{ACH}_{50}$.

\section{HVAC}

The HVAC system (including ducts) was located in the crawlspace. The air conditioner had a 4 ton capacity and an efficiency of 9 SEER. The gas furnace had a 100 kBtuh capacity with a rated efficiency of 80 AFUE. With all of the ducts in the crawlspace, the entire HVAC system was located outside of the conditioned envelope. The ducts were poorly sealed as determined by initial diagnostic tests. Since the ducts could not be pressurized to 25Pa during testing, a "can't reach factor" was used to determine a total leakage to the outside of $1,254 \mathrm{CFM}_{25}$ (or $42 \%$ of the conditioned floor area). Also, most of the duct runs were either not insulated or poorly insulated with newspaper and plastic mats as shown in Figure 48.

\footnotetext{
${ }^{26}$ GA International Energy Conservation Code Supplements and Amendments 2011
} 


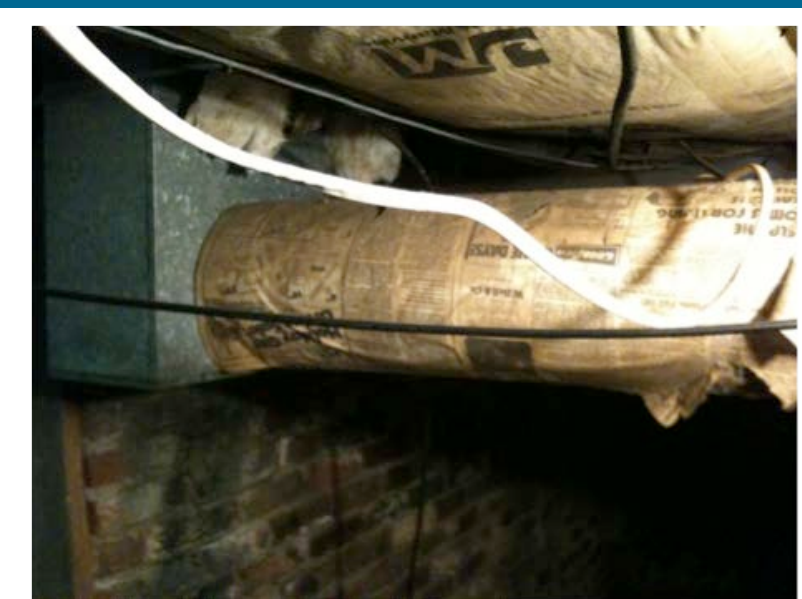

Figure 48. Ducts with newspaper used as insulation

\section{Lighting, Water Heating, Appliances}

The gas water heater is located in the vented crawlspace. It has a storage capacity of 50 gallons and is rated at $0.57 \mathrm{EF}$. The house has $0 \%$ CFL lighting and no ENERGY STAR appliances. Both the range and oven are electric.

\section{Health and Safety}

A thorough combustion safety test was performed on the water heater and furnace, because even though the units are considered to be outside of the envelope, there were major air leakage pathways that connect the area to the living space. Both units passed all components of the combustion safety test: spillage, draft, and CO.

Gas leaks were detected off of the main gas line for the furnace. 


\section{Retrofit Measures}

Using the prioritization protocol for this retrofit study, the following retrofit priorities were determined.

Table 24. South Carolina priority list

\begin{tabular}{|l|l|c|}
\hline \multicolumn{1}{|c|}{ Improvement } & \multicolumn{1}{c|}{ Existing condition } & Priority \\
\hline Air sealing & $\sim 1.15 \mathrm{ACH}_{\text {natural }}$ & $\mathrm{A}$ \\
\hline Improve ducts & $42 \%$ duct leakage & $\mathrm{A}$ \\
\hline $\begin{array}{l}\text { Insulate ATTIC (attic floor air sealing } \\
\text { must precede insulation work) }\end{array}$ & $\mathrm{R}-10-\mathrm{R}-19$ & $\mathrm{~B}$ \\
\hline Insulate WALLS & None & $\mathrm{C}$ \\
\hline Insulate FLOOR & R-13 & $\mathrm{C}$ \\
\hline $\begin{array}{l}\text { Insulate BASEMENT/CRAWLSPACE } \\
\text { WALLS }\end{array}$ & None & $\mathrm{B}$ \\
\hline Radiant barrier & No radiant barrier & $\mathrm{D}$ \\
\hline Replace heating system & 80 AFUE & $\mathrm{C}$ \\
\hline Replace cooling system & 9 SEER & $\mathrm{A}$ \\
\hline Replace water heater & .57 Gas & $\mathrm{C}$ \\
\hline Insulate water heater and pipe & Gas & $\mathrm{C}$ \\
\hline Improve windows & Metal single pane \\
\hline
\end{tabular}

Measures that received a priority of A or B from the prioritization protocol listed in Table 24were used as a basis for discussion with the homeowner and retrofit contractor on determining the final retrofit package. Retrofit measures included in the final package are described in the following text.

\section{Envelope}

As can be seen in the retrofit priority list in Table 24, air sealing and attic insulation were categorized as A and B priorities, respectively. As such, the ceiling plane would be a primary point of focus in completing these measures. However, the contractor suggested that it would be more difficult to adequately seal all of the ceiling penetrations and bypasses than it would be to encapsulate the attic with open-cell spray foam. This was in large part due to the different ceiling plane heights in the attic as shown in Figure 44. While encapsulating the attic can be viewed as a more effective approach to air sealing and insulating attic penetrations, it is often cost prohibitive if the HVAC system is not located in the attic. In these cases, encapsulating the attic brings the HVAC system into the semi-conditioned volume of the building where temperatures are more moderate and typically only vary by approximately $5-15^{\circ} \mathrm{F}$ from the interior temperature set point. This is in contrast to conventional attics where the temperatures often exceed interior set points by $50^{\circ} \mathrm{F}$ or greater. In addition, the energy penalty of duct leakage is mitigated, since the "lost" conditioned air provides unintentional conditioning to the living space.

However, since the existing air conditioning system in South Carolina needed to be replaced, along with ducts that needed to be repaired or replaced, the determination was made to replace

\footnotetext{
${ }^{27} \mathrm{ACH}_{\text {natural }}=\mathrm{ACH}_{50} / \mathrm{N}_{\text {corrected }}$, where $\mathrm{N}_{\text {corrected }}$ is the height-corrected LBL "N-factor" (http://www.bpi.org/Web\%20Download/BPI\%20Standards/Building\%20Analyst\%20Professional_2-28-05nNCnewCO.pdf)
} 
the HVAC system and relocate it to the attic. This would make encapsulating the attic more cost-effective and would yield a higher energy efficiency benefit than only sealing attic bypasses and adding more insulation while leaving the HVAC in the unconditioned volume. As a part of maintenance for this home, the homeowner decided to repair any roof damage prior to completing the retrofit. Repairing the roof was needed to enable encapsulating the attic as a retrofit measure.

The attic was encapsulated by applying open-cell spray foam between the 2" x 6" rafters. The final layer of spray foam was applied in a manner that both filled cavity between the rafters and left a continuous layer over the rafters to eliminate thermal shorts. A picture of the roofline after the open-cell spray foam was applied is shown in Figure 49 below.

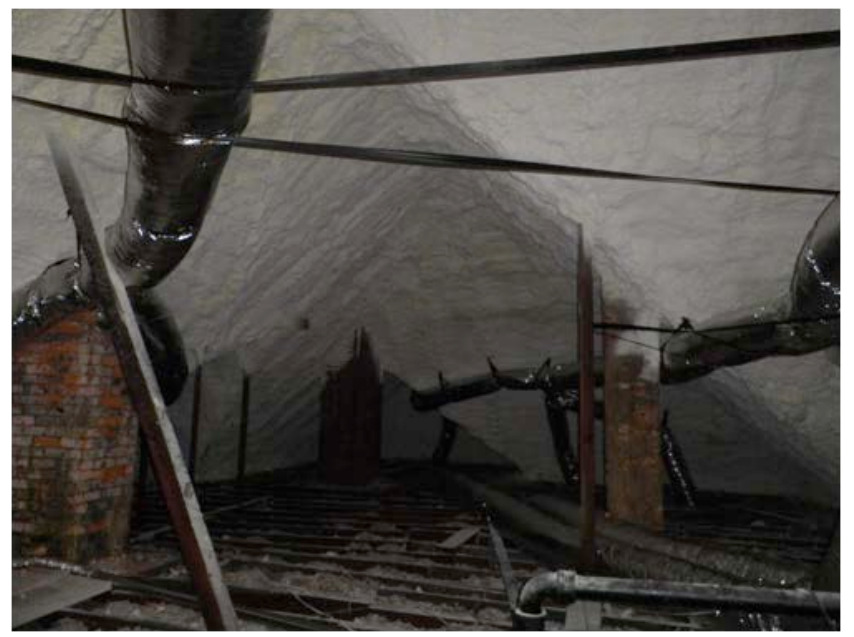

Figure 49. Photograph of attic after open-cell spray foam has been applied to the roofline

Because the roofline was insulated, the thermal and pressure boundary now exists at the roof, and the attic is now considered a semi-conditioned volume and can be included in the building's total conditioned volume. This results in an additional $20,000 \mathrm{ft}^{3}$ added to the conditioned volume. Figure 50 shows the 3-D model of the new envelope with the added attic volume. The gable walls were insulated with 3.5 ” of open-cell spray foam.

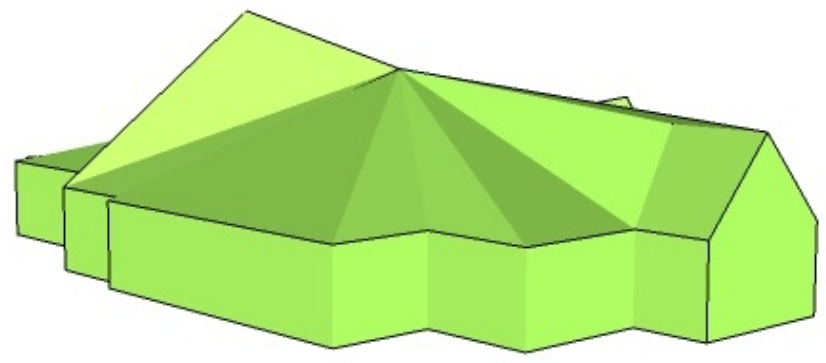

Figure 50. South Carolina post-retrofit building envelope.

\section{HVAC}


As discussed, the existing HVAC system was replaced and relocated to the semi-conditioned attic; thereby, bringing the system into the conditioned space. The new system consisted of a 4 ton, ENERGY STAR 14.5 SEER air conditioning unit, and a 90 kBtuh, 95 AFUE sealedcombustion gas furnace. Because the gas furnace is located in the attic that is now semiconditioned, combustion safety risks were mitigated by installing a sealed combustion unit.

Ceiling registers were added to replace the existing floor registers that were utilized by the previous system. The floor registers were capped as shown in Figure 51Figure 50.

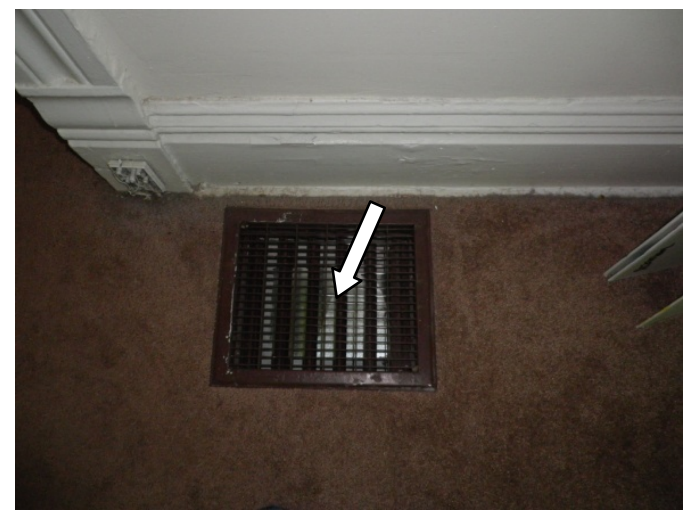

Figure 51. Capped floor register

\section{Lighting, Water Heating, Appliances}

The water heater was upgraded to a 50 gallon A.O. Smith Vertex water heater, which is a powervented high-efficient gas water heater. The water heater remained in the vented crawlspace. However since significant bypasses existed between the crawlspace and the building envelope, installing a power-vent water heater helped to mitigate combustion safety risks that could arise. Therefore, the water heater installation served the dual purpose of eliminating risks of combustion safety in a conditioned space, while also providing increased energy savings. No lighting and appliance retrofits were installed.

\section{Health and Safety}

Combustion safety issues were addressed by replacing the atmospherically vented water heater and furnace with sealed-combustion units. The gas lines that were leaking previously were replaced.

\section{Simulated Energy Savings}

As discussed earlier, the occupancy variation that occurs on annual basis limits the year to year comparisons based on occupancy schedules. In fact, conversation with the building tenants revealed that temperature set points could vary on a daily basis, based on which occupant was in the building at a certain time (i.e. one person may like the temperature a little cooler than the next). With this in mind, simulated energy use was based on temperature schedules as outlined in the Building America House Simulation Protocols. These operating conditions are set points of $76^{\circ} \mathrm{F}$ for the cooling season and $71^{\circ} \mathrm{F}$ for the heating season.

Table 25 shows the simulated energy savings from the implemented retrofit measures. In total, there is an estimated $45 \%$ reduction in source energy consumption. Due to the significant 
amount of duct leakage in the pre-retrofit case, coupled with the poor efficiency of the air conditioning unit, the largest energy savings are projected to be due to improvements in the HVAC system.

As can be seen in Figure 52, the energy savings for the primary building loads are significant. The heating and cooling load energy savings are $62 \%$ and 55\%, respectively. The water heating load improvement is substantial as well with more than $25 \%$ in projected energy savings.

Table 25. South Carolina recommended package with simulated energy savings from EnergyGauge

\begin{tabular}{|l|r|r|r|r|}
\hline & \multicolumn{1}{|c|}{$\begin{array}{c}\text { Predicted } \\
\text { Site } \\
\text { Energy } \\
\text { (MMBtu) }\end{array}$} & $\begin{array}{c}\text { Predicted } \\
\text { Source } \\
\text { Energy } \\
\text { (MMBtu) }\end{array}$ & $\begin{array}{c}\text { Site } \\
\text { Energy Savings } \\
\text { (\% per measure) }\end{array}$ & $\begin{array}{c}\text { Source } \\
\text { Energy Savings } \\
\text { (\% per measure) }\end{array}$ \\
\hline $\begin{array}{l}\text { South Carolina Simulated } \\
\text { Energy Use }\end{array}$ & 294 & 448 & & \\
\hline $\begin{array}{l}\text { + Envelope } \\
\text { Improvements }\end{array}$ & 259 & 406 & $12 \%$ & $3 \%$ \\
\hline $\begin{array}{l}\text { ++ HVAC System } \\
\text { Improvements }\end{array}$ & 146 & 251 & $38 \%$ & $2 \%$ \\
\hline $\begin{array}{l}\text { +++ Water Heater } \\
\text { Improvements }\end{array}$ & 140 & 244 & $2 \%$ & $45 \%$ \\
\hline Total Retrofit Investment & & & $52 \%$ & \\
\hline
\end{tabular}

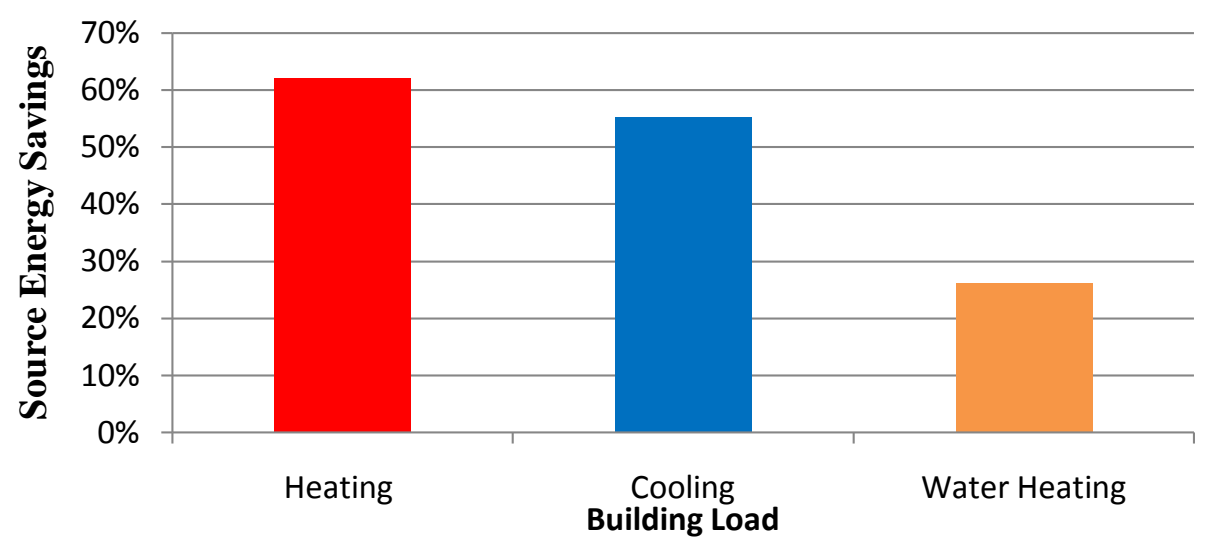

Figure 52. Simulated Energy Savings from Primary Building Loads

\section{Diagnostics and Test Out}

When scheduling with subcontractors permitted, Blower Door tests were done at intervals to investigate the effectiveness of individual retrofit measures. The results are shown in Table 26 in the order in which the tests were done. Conducting successive diagnostic Blower Door tests can yield valuable information and insight into the impact of individual measures and facilitate more accurate prediction of energy savings. For example, as seen in the table, low-density, open-cell spray foam is an effective approach to insulate the band joist in the crawlspace, while also reducing the overall building infiltration. Encapsulating the roofline and insulating the band joist in the crawlspace with open-cell spray foam had similar infiltration reduction results of $15 \%$ and $12 \%$ of the initial building infiltration. In total, the infiltration was reduced by approximately 
28\%. While a total $\mathrm{CFM}_{50}$ reduction of $2950 \mathrm{CFM}$ is significant, there is still a substantial amount of building infiltration remaining. A large amount of this infiltration can likely be attributed in part to the prevalence of older single pane windows with wooden frames that are typical air leakage pathways.

At the time of this report's release, the researchers are planning to work with the homeowner and retrofit contractor to see if additional air sealing can be done. However, this case illustrates a common retrofit scenario where planned infiltration improvements do not result in expected performance. Revisiting the home to identify more infiltration improvements is difficult given the competing constraints on the amount of time a building contractor can commit to returning to a home to conduct more investigation versus the amount of homeowner "annoyance" that can reasonably be tolerated. A particular "annoyance", and thereby a significant barrier to returning to the home for more air sealing analysis, is the time away from work that a homeowner has to use to be at the home during the building retrofit. New construction, renovations, and rehabilitations may experience the similar constraint of contractor time, but are not often subject to the requirement that the homeowner be on-site and thereby off-work. In this home, the services of a home energy consultant were offered to identify additional infiltration reduction pathways; however, the building owner declined to try to minimize the disruption to the tenant's life.

Table 26. Pre-retrofit and post-retrofit air infiltration diagnostics

\begin{tabular}{|l|c|c|}
\hline Retrofit Measure Tested & $\begin{array}{c}\text { Blower Door Test Result } \\
\left(\mathbf{C F M}_{\mathbf{5 0}} / \mathbf{A C H}_{\mathbf{5 0}}\right)\end{array}$ & Percent Reduction $^{28}$ \\
\hline Pre-retrofit & $10,460 / 23.3$ & $12 \%$ \\
\hline $\begin{array}{l}\text { Crawlspace band insulated with } \\
\text { open cell spray foam }\end{array}$ & $9,200 / 20.5$ & $15 \%$ \\
\hline $\begin{array}{l}\text { Roofline insulated and attic } \\
\text { sealed }\end{array}$ & $7,640 / 17.0$ & $0 \%$ \\
\hline $\begin{array}{l}\text { Chimney plugs added and floor } \\
\text { registers capped }\end{array}$ & $7,640 / 17.0$ & $1 \%$ \\
\hline Additional air sealing measures & $7,510 / 16.8$ & $28 \%$ \\
\hline Final & $7,510 / 16.8$ & \\
\hline
\end{tabular}

When an attic is encapsulated, the retrofit measures are often described as insulating the roofline and sealing the attic. However, in most home energy retrofits, terminology such as "sealing the

\footnotetext{
${ }^{28}$ Percent reduction is determined by evaluating the cfm50 reduction for each of the retrofit measures as a ratio of the total building infiltration.
} 
attic" should be used and understood with care. It is not clear, and probably not likely, that spray foam installers are able to perfectly seal all attics that are "sealed". Since partially sealed attics can lead to moisture penetration into the attic volume which thereby increases the potential for condensation, wood rot, and mold, the level of attic sealing resulting from attic encapsulation is worth distinction. Because of the questions the researchers in this study had concerning the level of "attic sealing" that occurs in retrofits, Blower Door tests were conducted with the attic hatch/door closed and with the attic hatch/door open. In the former test case the attic is only partially connected to the house through leakage pathways in the ceiling and in ducts located in the attic. However, in the latter case where the attic hatch/door is open, the attic volume is now better connected to the house such that additional building infiltration can be likely attributed to the attic volume. If the attic is sealed from the exterior, there should be little to no additional infiltration when the attic hatch/door is opened. In this case, with the attic door/hatch closed, the Blower Door test yielded an infiltration of 7,640 CFM 50 (Table 26). In contrast, with the attic

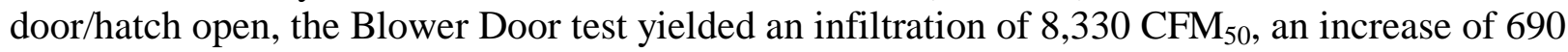
$\mathrm{CFM}_{50}$. This suggests that air leakage pathways remain in the attic even after the attic has been "sealed". Because the researchers assumed that this is a frequent occurrence in encapsulated attics, the contractor was not asked to search for infiltration points. However, dataloggers will be placed in the attic so that moisture levels and temperatures can be monitored and the impact of the attic infiltration can be evaluated in 2011-2012.

The impact of replacing the ducts is shown in Table 27. Whereas initially, the duct leakage to the outside of the building envelope was measured as $1,254 \mathrm{CFM}_{25}$, after new ducts were installed with attention paid to properly sealing all potential leakage points, only $68 \mathrm{CFM}_{25}$ of duct leakage was found. Using EnergyGauge to simulate the energy savings that are likely to result from an improvement of this magnitude (95\% improvement) yields an approximately 33\% increase in HVAC system performance. Additionally, because the large leakage rate contributed to unbalanced air flows through the house, sealing the ducts will also provide superior thermal comfort.

Table 27. Pre-retrofit and post-retrofit duct leakage diagnostics - duct leakage to outside measured as air flow at $25 \mathrm{~Pa}\left(\mathrm{CFM}_{25}\right)$ and normalized as a percentage $\left(\mathrm{CFM}_{25} /\right.$ conditioned area $\left.\left(\mathrm{ft}^{2}\right)\right)$

\begin{tabular}{|l|l|l|}
\hline $\begin{array}{l}\text { Duct Leakage (\% to outside) - } \\
\text { Notes: (\% to outside) }-\mathrm{CFM}_{25} / \mathrm{conditioned} \text { area }\left(\mathrm{ft}^{2}\right)\end{array}$ \\
\hline & $\mathbf{C F M}_{25}$ & \% Leakage to Outside* \\
\hline Pre-Retrofit & 1,254 & $42 \%$ \\
\hline Post-Retrofit & 68 & $2 \%$ \\
\hline \% Reduction & $95 \%$ & $95 \%$ \\
\hline
\end{tabular}

* The conditioned area is equal to $2,949 \mathrm{ft}^{2}$.

Overall the final HERS index improved from 183 to 85, which reflects the significant energy savings that are predicted for this retrofit. In FY12, whole-house energy consumption, along with the contribution of major loads such as the air conditioner, will be submetered by an eMonitor device installed in May 2011. Additionally, utility bills will continue to be collected for comparison with pre-retrofit utility bills. 


\section{South Carolina Cost and Scope of Work}

The retrofit measures described in this report were completed in August 2011, at a total cost of about $\$ 38,380$. Table 28 provides a summary of the final scope of work and breakdown of the costs.

Table 28. South Carolina final scope of work and costs.

\begin{tabular}{|c|c|c|c|}
\hline Home Characteristics & Existing Conditions & Upgrades & Proposed Costs \\
\hline Exterior Walls & $\mathrm{R}-0$ & N/A & N/A \\
\hline $\begin{array}{c}\text { Attic/ } \\
\text { Knee walls }\end{array}$ & $\mathrm{R}-11$ & $\begin{array}{l}\text { Attic encapsulated } \\
\text { with R-21 open- } \\
\text { cell spray foam on } \\
\text { roofline }\end{array}$ & $\$ 14,780$ \\
\hline Foundation Subfloor & $\mathrm{R}-13$ & $\begin{array}{l}\text { Air-sealing and } \\
\text { reinstall existing } \\
\text { R-13 batts to have } \\
\text { paper-side facing } \\
\text { subfloor; } \\
\text { R-11 insulation } \\
\text { added to } \\
\text { crawlspace band } \\
\end{array}$ & $\$ 3,820$ \\
\hline Foundation Walls & $\mathrm{R}-0$ & N/A & N/A \\
\hline Cooling & 4 ton 9 SEER & 4 ton 14.5 SEER & $\begin{array}{c}\$ 15,480 \\
\text { (includes the cost of }\end{array}$ \\
\hline Heating & 100 kBtuh, 80 AFUE & $\begin{array}{c}90 \text { kBtuh, } 95 \\
\text { AFUE }\end{array}$ & $\begin{array}{l}\text { duct sealing and new } \\
\text { R-8 insulated flex } \\
\text { ducts) }\end{array}$ \\
\hline DHW & $.59 \mathrm{EF}$ & $\begin{array}{l}50 \text { gallon A.O. } \\
\text { Smith Vertex® } \\
\text { water heater }\end{array}$ & $\begin{array}{l}\text { Donated by A.O. } \\
\text { Smith (MSRP = } \\
\$ 2,600) ; \$ 1,700 \text { for } \\
\text { installation }\end{array}$ \\
\hline Windows & $\begin{array}{l}\text { Single-pane wood; Single- } \\
\text { pane metal }\end{array}$ & N/A & N/A \\
\hline
\end{tabular}




\section{Lakeview}
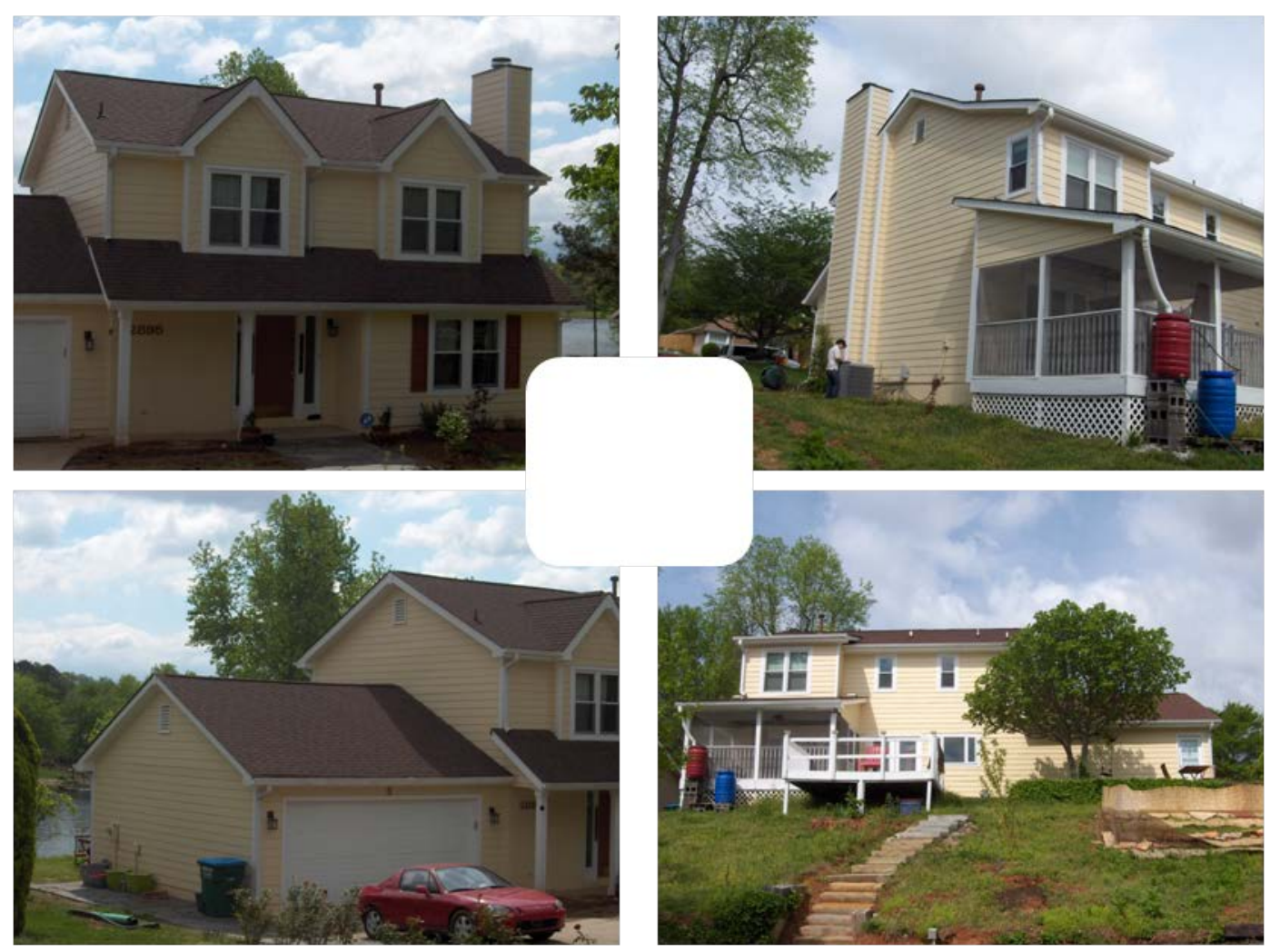

\section{Lakeview Home Profile}

Originally built in 1985, Lakeview is a two-story, single-family detached home with $1,710 \mathrm{ft}^{2}$ of living area, of which first floor comprises $880 \mathrm{ft}^{2}$. There are three bedrooms and three bathrooms. Lakeview has a traditional vented attic and a slab foundation. A family of two adults and one child lives in this home.

The family's energy costs from December 2009- November 2010 are shown in Figure 27. With a total annual cost of \$2,074 ( 80 MMBtu of site energy), the family’s energy costs are approximately equal to the average annual site energy consumption for a typical home in the southeast of this size $\left(81 \mathrm{MMBtu}^{29}\right)$. However, because the homeowner owns an electric car that is charged nightly, the home's energy consumption is not typical. The family is energy conscious and considers saving energy a priority. In winter months in 2010, the family conserved heat by only using space heaters when and where necessary.

\footnotetext{
${ }^{29}$ Per the 2010 Buildings Energy Data Book, energy consumption for the South Atlantic region is 47.4 kBtu per square foot.
} 


\section{LAKEVIEW PRE-}

RETROFIT

CHARACTERISTICS

TYPE: Two-story, single-family

home

SIZE: $1,710 \mathrm{ft}^{2}$

Occupancy: Two adults and one child

\section{INITIAL ENVELOPE}

\section{PROFILE}

WALL INSULATION: R-11

SLAB INSULATION: None

ATTIC INSULATION: R-21

\section{INITIAL MECHANICAL}

\section{PROFILE}

Location: attic

Cooling: 12 SEER (electric)

Heating: Space heaters where needed

\section{WATER HEATER: $0.9 \mathrm{EF}$ \\ $\underline{\text { (electric) }}$}

\section{INITIAL DIAGNOSTIC}

\section{RESULTS}

\section{HERS: 115}

HESCORE: 6

AIR INFILTRATION:

2,670 $\mathrm{CFM}_{50}\left(11.7 \mathrm{ACH}_{50}\right)$

DUCT LEAKAGE TO OUTSIDE:

$530 \mathrm{CFM}_{25}$

DUCT INSULATION: R-6

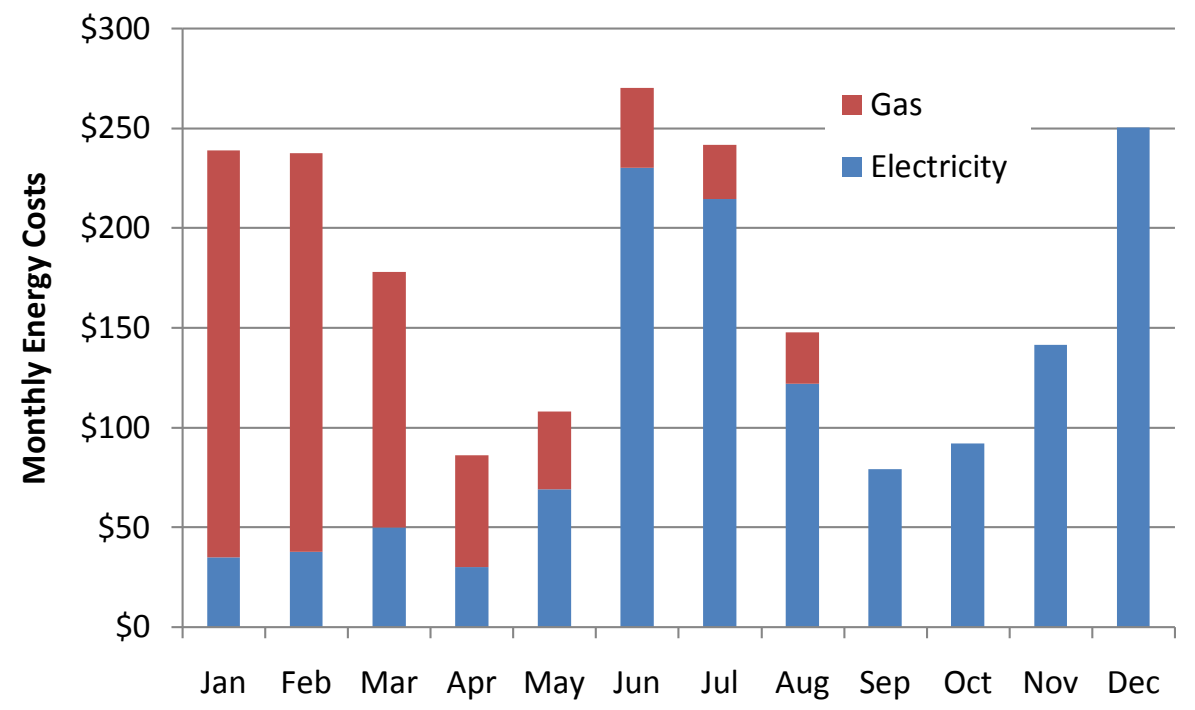

Figure 53. Lakeview monthly energy costs

\section{Lakeview Initial Characteristics}

\section{Envelope Profile}

An illustration of the building envelope is shown in Figure 54. The envelope is bounded by an un-insulated slab floor below the first floor and an insulated ceiling plane above the second floor. The dark green sections of the figure illustrate represent the attic knee walls created by the porch overhang in the front of the home. The yellow section in the figure represents the R-11 insulated wall between the garage and the living space. The windows are all clear, double pane windows with vinyl frames. The walls on the first and second floor are 8" in height.

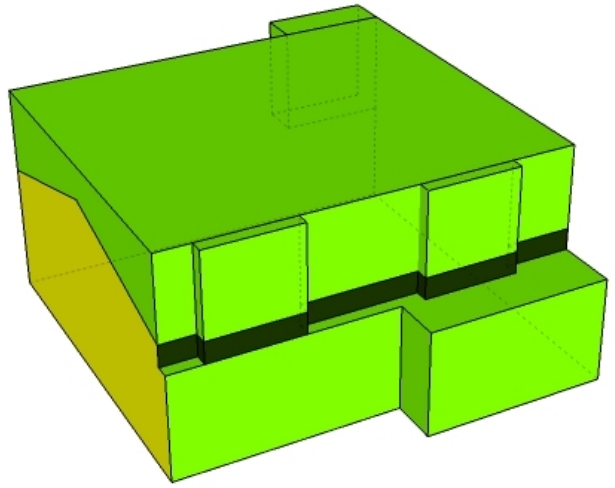

Figure 54. Illustration of the initial building envelope

Given the age of Lakeview, exterior wall insulation was expected. To aid in the building assessment, thermal infrared imaging was done. The 
assessment was performed as early in the morning as permitted by the tenant (around 7:00 a.m.) before the building gained a great amount of solar load from the rising sun. Through the thermal scan and visual inspection of the house, insulation was evident in exterior walls, for which an insulation value of R-11 was assumed. However, investigation of the thermal images highlighted areas where voids in the insulation existed (Figure 80).
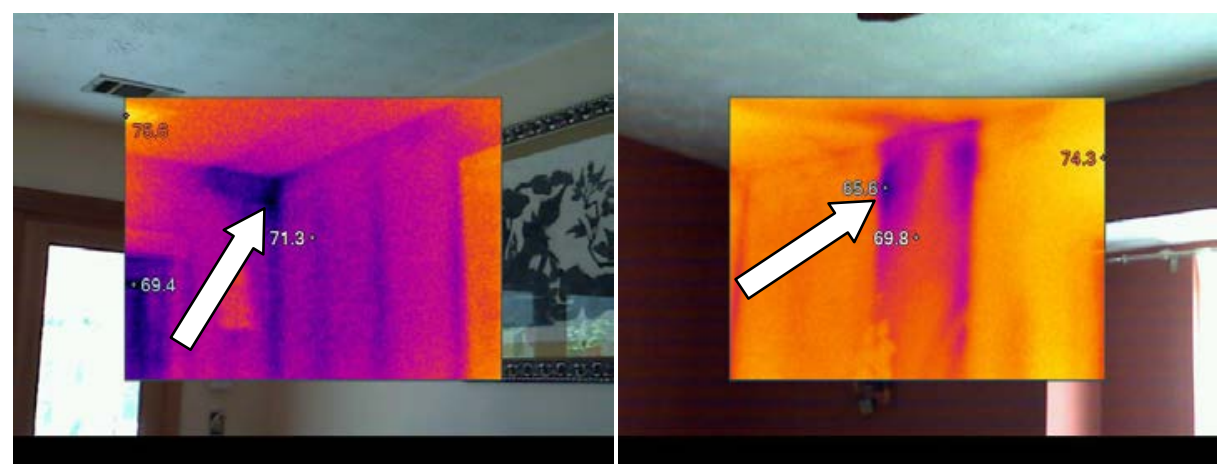

Figure 55. Thermal image highlighting insulation voids in exterior walls.

In the attic, the ceiling has blown fiberglass with an average insulation coverage equivalent to approximately R-21. There was only a limited area of knee walls, which were insulated with R11 batts, present in this home.

There was also no slab insulation present.

During the initial home energy assessment, a Blower Door test was conducted to evaluate the air infiltration. The total air leakage rate was 2,670 $\mathrm{CFM}_{50}$. With a conditioned volume of 13,690 $\mathrm{ft}^{3}$, the air exchange rate for Lakeview was approximately $11.7 \mathrm{ACH}_{50}$.

\section{HVAC}

Conditioned air is provided in Lakeview by a 3.5 ton capacity air conditioner, with an efficiency of 12 SEER. When the homeowner initially moved into the home, heating was provided by a natural gas furnace with a capacity of $66 \mathrm{kBtuh}$ and a rating of 80 AFUE. However in an effort to only use electricity in the home, the family had the gas unit turned off. Even though the home had an electric heat pump with an HSPF of 7.5, space heaters were used to provide heat during the winter months. The thermostat for the HVAC system was located on the second floor. The HVAC system, along with all ducts, was located in the attic. The ducts for this system were insulated with R-6 insulation. Duct leakage tests were performed and yielded a duct leakage of $526 \mathrm{CFM}_{25}$ or $31 \%$ of the conditioned floor area.

\section{Lighting, Water Heating, Appliances}

Similar to the gas furnace, gas water heater initially in the home was replaced with an electric unit soon after the family moved in the home in 2009. The water heater was located in the garage and has a 50 gallon capacity and an efficiency rating of .90 EF. 
The house had 100\% CFL lighting and ENERGY STAR appliances - dishwasher, refrigerator and washer. The range and oven were electric; however, the homeowner mostly uses induction cook tops for cooking needs.

\section{Health and Safety}

Combustion safety testing was not needed, because there was no gas usage in the home. 


\section{Retrofit Measures}

Using the prioritization protocol for this retrofit study, the following retrofit priorities were determined. In contrast to other homes in this study, most measures received a C or D priority. Only the recommendation to improve ducts received an A priority. Therefore, the prioritization protocol was not a central point of focus with regard to selected energy saving measures.

Table 29. Lakeview priority list

\begin{tabular}{|c|c|c|}
\hline Improvement & Existing condition & Priority \\
\hline Air sealing & $\sim 0.6 \mathrm{ACH}_{\text {natural }}$ & $\mathrm{B}$ \\
\hline Improve ducts & $\geq 31 \%$ duct leakage & $\mathrm{A}$ \\
\hline $\begin{array}{c}\text { Insulate ATTIC (attic floor air sealing } \\
\text { must precede insulation work) }\end{array}$ & $\mathrm{R}-21$ & $\mathrm{C}$ \\
\hline Radiant barrier & No radiant barrier & $\mathrm{D}$ \\
\hline Replace heating system & $80-89$ AFUE/ 7 HSPF & $\mathrm{D}$ \\
\hline Replace cooling system & 12 SEER & $\mathrm{D}$ \\
\hline Replace water heater & .90 electric & $\mathrm{D}$ \\
\hline Insulate water heater and pipe & Electric - insulated & $\mathrm{D}$ \\
\hline Improve windows & Vinyl double-pane & $\mathrm{D}$ \\
\hline
\end{tabular}

Prior to becoming a part of this retrofit study, the homeowner decided to undergo energy saving measures of encapsulating the attic and replacing the water heater with a solar thermal system. These measures are explained in the following text.

\section{Envelope}

As an approach to bring the HVAC into the building envelope, in addition to reducing the thermal load on the home from the attic, the homeowner decided to encapsulate the attic with open-cell spray foam. Approximately 6" of open-cell spray foam, sufficient to provide a continuous layer of insulation over the $2 \times 6$ rafters, was applied on the roofline (Figure 56). The approximate equivalent insulation is R-21. In addition to open-cell spray foam application on the gables, rigid foam board was foam flashed to the gable vents to seal the attic from the outside.

\footnotetext{
${ }^{30} \mathrm{ACH}_{\text {natural }}=\mathrm{ACH}_{50} / \mathrm{N}_{\text {corrected }}$, where $\mathrm{N}_{\text {corrected }}$ is the height-corrected LBL "N-factor" (http://www.bpi.org/Web\%20Download/BPI\%20Standards/Building\%20Analyst\%20Professional_2-28-05nNCnewCO.pdf)
} 

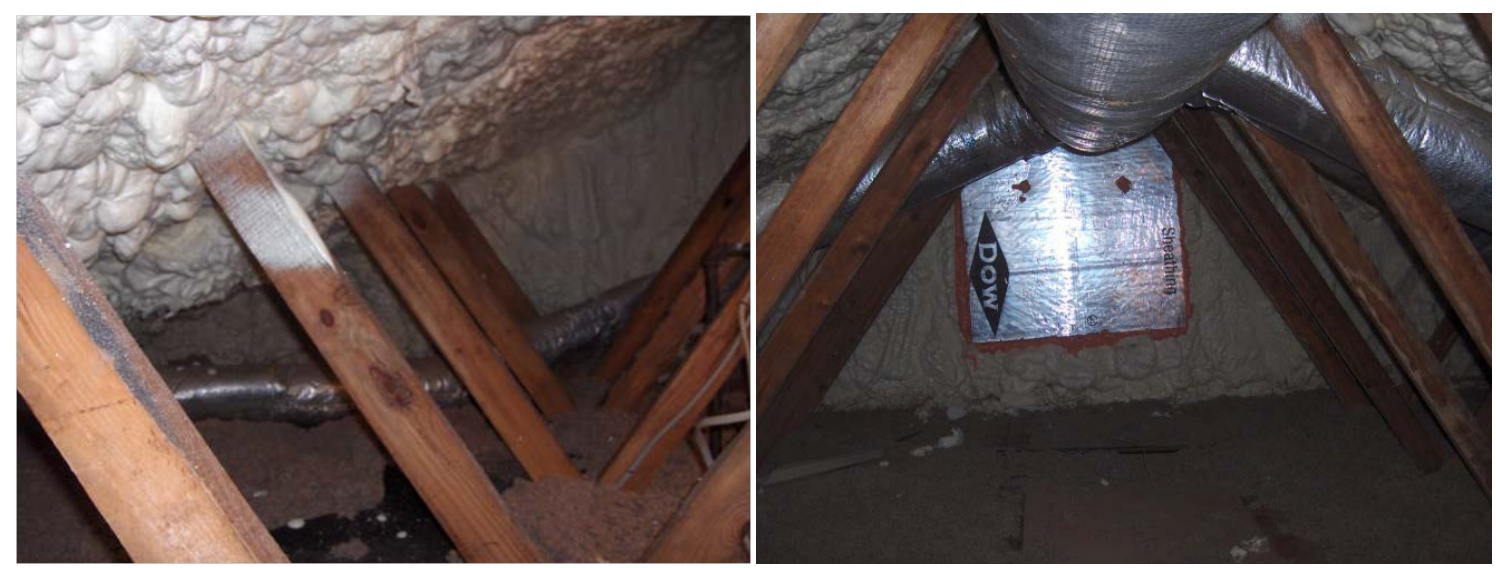

Figure 56. Open cell spray foam applied in the roofline and gables

As a result of encapsulating the attic, the attic volume is now considered semi-conditioned and can be included in the building's total conditioned volume. This results in an additional 7,943ft ${ }^{3}$ added to the conditioned volume. Figure 57 shows the 3-D model of the new envelope with the added attic volume.

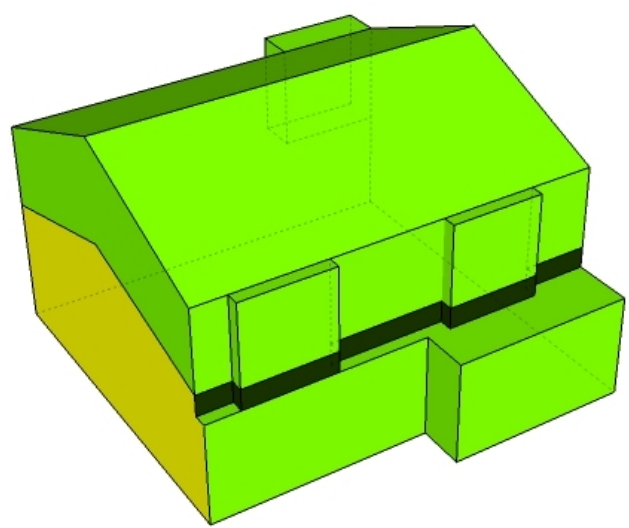

Figure 57. Illustration of the new building envelope with the attic included in the conditioned volume

\section{HVAC}

In addition to the HVAC system location being brought into the building envelope through attic encapsulation, the system was upgraded to a Daikin Inverter ducted heat pump. This variable capacity system is expected to be capable of meeting the building heating load at temperatures as low as $14^{\circ} \mathrm{F}$ without the use of auxiliary resistance heat. To provide supplemental heat when needed, an electric heater option of $3 \mathrm{~kW}$ was included with the heat pump. The system has an efficiency rating of 18 SEER and $8.9 \mathrm{HSPF}$. In contrast to the 3.5 ton cooling capacity of the air conditioning system initially in the home, the new system only has a cooling capacity of 2 tons. A Manual J calculation was done, based on the building envelope improvements, and it was determined that an air conditioner with a 2 ton capacity would be sufficient. Because the system was downsized significantly, the majority of HVAC contractors consulted advised the 
homeowner to resize the ducts to match the new system. Because there was a near consensus of a recommended approach by HVAC contractors, the homeowner decided to also resize the ducts.

\section{Lighting, Water Heating, Appliances}

A solar thermal water heater was installed on the garage roof of the home (Figure 58). The installed collector consists of two flat panels (8' x 4') with a pressurized glycol system that connects to an 80 gallon storage tank. The existing 50 gallon electric water heater was retained in order to provide hot water heating at times when there is insufficient solar loading. For solar applications, it is optimal to places panels on a southern facing roof. However, because the home has a west orientation, this was not feasible in this application and therefore the solar thermal panels face east. With this in mind, the overall energy reduction possible from the solar thermal installation will be reduced.

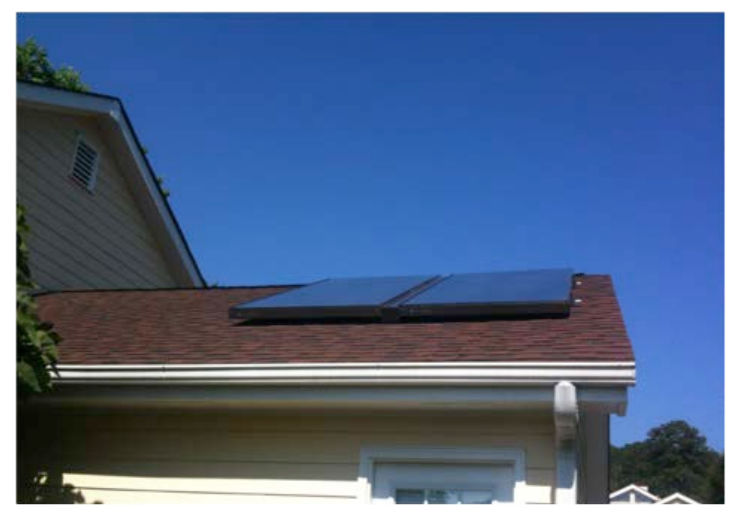

Figure 58. Solar thermal hot water panels installed on the garage roof.

\section{Health and Safety}

No combustion safety remediation needed.

\section{Simulated Energy Savings}

Table 30 shows the simulated energy savings from the implemented retrofit measures. For modeling purposes, it was assumed that the heating load in the home was supplied via the 7.5 HSPF heat pump. The pre-retrofit home was also modeled as all-electric. The initial gas water heater and gas furnace in the home when the homeowner first moved into the home were not modeled. 
Table 30. Lakeview retrofit package with simulated energy savings from EnergyGauge

\begin{tabular}{|l|r|r|r|r|}
\hline & $\begin{array}{l}\text { Predicted Site } \\
\text { Energy (MMBtu) }\end{array}$ & $\begin{array}{l}\text { Predicted Source } \\
\text { Energy (MMBtu) }\end{array}$ & $\begin{array}{l}\text { Site Energy } \\
\text { Savings (\% per } \\
\text { measure) }\end{array}$ & $\begin{array}{l}\text { Source Energy } \\
\text { Savings (\% per } \\
\text { measure) }\end{array}$ \\
\hline Simulated Energy Use & 59 & 185 & $15 \%$ & $15 \%$ \\
\hline $\begin{array}{l}+ \text { Envelope } \\
\text { Improvements }\end{array}$ & 50 & 157 & $10 \%$ & $10 \%$ \\
\hline $\begin{array}{l}++ \text { HVAC System } \\
\text { Improvements }\end{array}$ & 44 & 138 & $6 \%$ & $6 \%$ \\
\hline $\begin{array}{l}+++ \text { Water Heater } \\
\text { Improvements }\end{array}$ & 40 & 127 & $31 \%$ & $31 \%$ \\
\hline Total Retrofit & & & & \\
\hline
\end{tabular}

In total, there is an estimated 31\% reduction in source energy consumption. Because the home was modeled as an all-electric home, the source and site energy savings are the same. The predicted source energy savings from envelope improvements are $15 \%$, and are the largest of the improvements in this retrofit. This is because the envelope improvements reduced building infiltration and the thermal load from the attic, in addition to changing the thermal environment of the HVAC system. Previously the HVAC system was located in the attic which experiences both extreme winter and summer temperatures. Therefore, bringing the HVAC system into the semi-conditioned volume resulted in HVAC savings that are attributed to the envelope improvement. The HVAC predicted energy savings of $10 \%$ are due to the improved energy performance of the ducted variable capacity system as well as the reduction in duct leakage when the new ducts were installed.

As can be seen in Figure 59, the energy savings for the primary building loads are significant. The heating and cooling load source energy savings are $52 \%$ and $50 \%$, respectively. The energy savings from the solar water heater are only 31\%, in part because of the sub-optimal installation of the system. For example, if it was possible to install the system on a south facing roof (NOT possible for this home, but if it was possible), the water heating energy savings would have been $47 \%$.

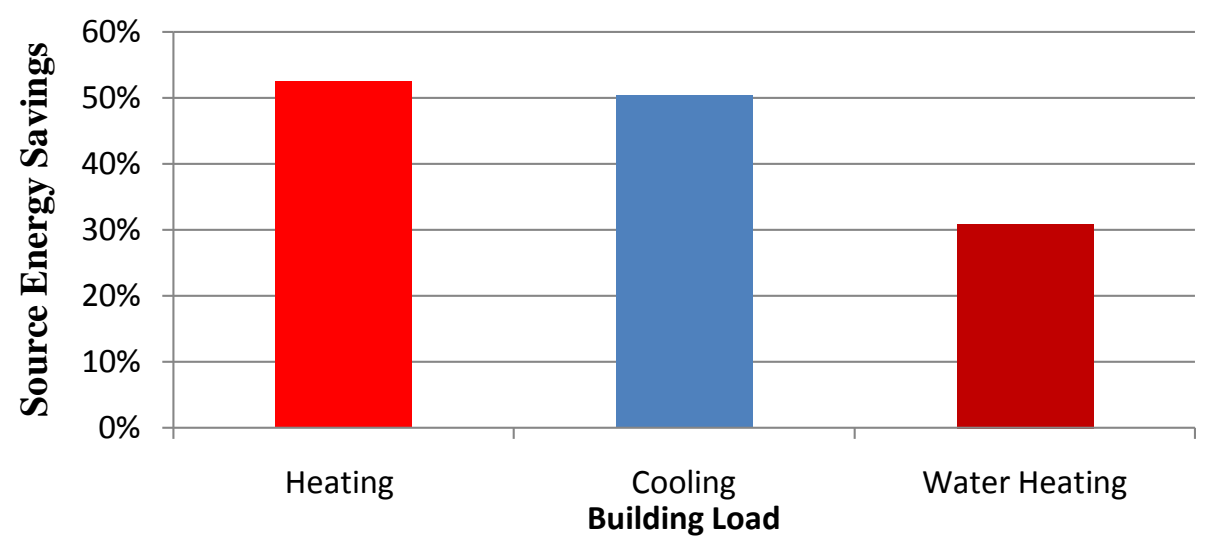

Figure 59. Simulated Energy Savings from Heating and Cooling Loads 


\section{Diagnostics and Test Out}

After all retrofit measures were completed, a test-out of Lakeview was performed. Salient testout diagnostics are shown in Table 31 and Table 32. Encapsulating the attic resulted in an infiltration reduction of $560 \mathrm{CFM}_{50}$, a $21 \%$ decrease. When an attic is encapsulated, the retrofit measures are often described as insulating the roofline and sealing the attic. However, in some home energy retrofits, terminology such as "sealing the attic" should be used and understood with care. It is not clear, that spray foam installers are able to perfectly seal all attics that are "sealed". Because of the questions the researchers in this study had concerning the level of "attic sealing" that occurs in retrofits, Blower Door tests were conducted with the attic access door closed and with the attic access open. In the former test case, the attic is only partially connected to the house through leakage pathways in the ceiling and in ducts located in the attic. However, in the latter case where the attic access is open, the attic volume is now better connected to the house such that additional building infiltration can be likely attributed to the attic volume. If the attic is sealed from the exterior, there should be little to no additional infiltration when the attic access is opened. In this case, with the attic access closed, the Blower Door test yielded an infiltration of 2,110 $\mathrm{CFM}_{50}$ (Table 31). In contrast, with the attic access open, the Blower Door test yielded an infiltration of 2,460 CFM $\mathrm{C}_{50}$, an increase of $350 \mathrm{CFM}_{50}$. This suggests that air leakage pathways remain in the attic even after the attic has been "sealed". Dataloggers will be placed in the attic so that moisture levels and temperatures can be monitored and the impact of the attic infiltration can be evaluated in 2011-2012.

Table 31. Pre-retrofit and post-retrofit air infiltration diagnostics

\begin{tabular}{|l|l|l|}
\hline Retrofit Measure Tested & $\begin{array}{l}\text { Blower Door Test Result } \\
\left(\mathbf{C F M}_{50} / \mathbf{A C H}_{50}\right)\end{array}$ & Percent Reduction \\
\hline Initial & $2,670 / 11.7^{*}$ & \\
\hline Final & $2,110 / 10.1^{*}$ & $21 \%$ \\
\hline
\end{tabular}

* $\mathrm{ACH}_{50}$ includes an initial building volume of $13,690 \mathrm{ft}^{3}$

The impact of relocating and replacing the ducts is shown in Table 32. Overall, there was a 79\% reduction in the overall duct leakage to the outside of the building envelope.

Table 32. Pre-retrofit and post-retrofit duct leakage diagnostics - duct leakage to outside measured as air flow at $25 \mathrm{~Pa}\left(\mathrm{CFM}_{25}\right)$ and normalized as a percentage $\left(\mathrm{CFM}_{25} /\right.$ conditioned area $\left.\left(\mathrm{ft}^{2}\right)\right)$

\begin{tabular}{|l|c|c|}
\hline & CFM $_{25}$ & \% Leakage to Outside \\
\hline Pre-Retrofit & 530 & $31 \%^{*}$ \\
\hline Post-Retrofit & 110 & $6.4 \%^{* *}$ \\
\hline \% Reduction & $79 \%$ & $79 \%$ \\
\hline
\end{tabular}

* The pre-retrofit conditioned area is equal to $1,710 \mathrm{ft}^{2}$.

** The post-retrofit conditioned area is equal to $1,710 \mathrm{ft}^{2}$. 
Overall the final HERS index improved from 115 to 71, which reflects the significant energy savings that are predicted for this retrofit. In FY12, it is planned to sub-meter whole-house energy consumption, along with the contribution of major loads such as the air conditioner with an e-Monitor energy logger. Additionally, utility bills will continue to be collected for comparison with pre-retrofit utility bills.

\section{Lakeview Cost and Scope of Work}

The total improvements for Lakeview are about $\$ 17,520$. Table 33 provides a summary of the final scope of work with associated costs.

Table 33. Lakeview final scope of work and costs.

\begin{tabular}{|l|l|l|c|}
\hline \multicolumn{1}{|c|}{ Home Characteristics } & \multicolumn{1}{|c|}{$\begin{array}{c}\text { Pre-Retrofit } \\
\text { Conditions }\end{array}$} & \multicolumn{1}{|c|}{ Retrofit Measures } & Final Costs \\
\hline Attic & $\begin{array}{l}\text { R-21 fiberglass (flat } \\
\text { ceiling) }\end{array}$ & $\begin{array}{l}\text { Attic encapsulated with R-21 } \\
\text { open-cell spray foam on } \\
\text { roofline }\end{array}$ & $\$ 1,720$ \\
\hline Cooling & 3.5 ton,12 SEER & 2 ton, 18 SEER & \multirow{2}{*}{$\$ 10,080$} \\
\cline { 1 - 3 } Heating & $\begin{array}{l}\text { Space heaters where } \\
\text { needed }\end{array}$ & $\begin{array}{l}8.9 \text { HSPF ducted inverter } \\
\text { heat pump }\end{array}$ & \multirow{2}{*}{$\$ 5,000$} \\
\hline Water Heating & 50 gallon tank, .90 EF & $\begin{array}{l}\text { Solar Thermal Water Heater } \\
\text { with a 80 gallon storage tank }\end{array}$ \\
\hline
\end{tabular}




\section{Yellow Jackets}

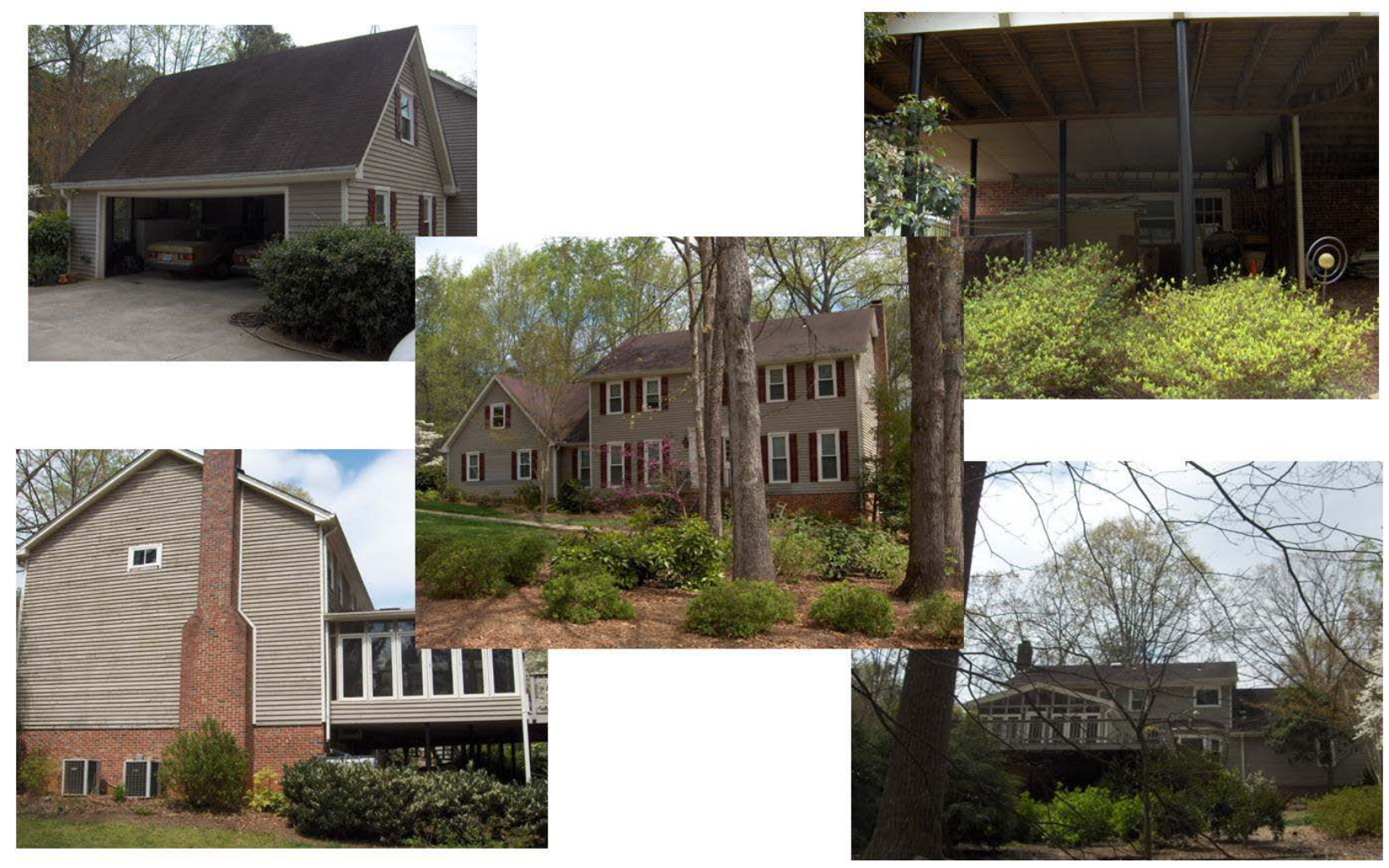

\section{Yellow Jackets Home Profile}

Originally built in the 1970's, Yellow Jackets is a two-story, single-family detached home with $3,170 \mathrm{ft}^{2}$ of living area. On the main floor there is $1,420 \mathrm{ft}^{2}$, while on the second floor there is $1,750 \mathrm{ft}^{2}$ of living area. Part of the second floor living area is comprised of a furnished room over the garage (FROG) with $350 \mathrm{ft}^{2}$. In total, there are five bedrooms and three bathrooms in this home with three adult occupants. Yellow Jackets has a traditional vented attic and an unconditioned, unfinished basement.

The homeowners have occupied the home for over 10 years. With energy efficiency being a high priority for their home, in previous years they have installed a hot water re-circulating pump with an on-demand cycle, installed low- flow toilets, and replaced all the windows with low-E, double-pane, vinyl windows. With retirement approaching, they have decided to prepare by initiating a whole-house retrofit, while maintenance items such as roof and siding replacement were being completed. They also wanted to provide conditioning to their unconditioned basement of approximately $1,400 \mathrm{ft}^{2}$ during this retrofit. In addition to energy efficiency as a primary motivation for completing a retrofit, the homeowner listed safety, comfort, and a healthy indoor environment as important priorities. In particular, the homeowners wanted to increase the comfort of the FROG. Because the retrofit contractor they selected to complete this project had partnered with researchers in this study, the homeowners were asked if this house could serve as 
YELLOW JACKETS

CHARACTERISTICS

TYPE: Two-story, single-family

home

SIZE: $3,169 \mathrm{ft}^{2}\left(1^{\text {st }}\right.$ floor: 1,424

$\mathrm{ft}^{2}, 2^{\text {nd }}$ floor: $1,745 \mathrm{ft}^{2}$ )

Occupancy: Three adults

\section{INITIAL ENVELOPE}

\section{PROFILE}

WALL INSULATION: R-11

KNEE WALL INSULATION: R-13

BAND INSULATION: None

ATTIC INSULATION: R-18 - R-

25

\section{INITIAL MECHANICAL}

\section{PROFILE}

FIRST FLOOR ZONE

Location: Unconditioned

basement

Cooling: 12 SEER (electric)

Heating: 80 AFUE (natural

gas)

SECOND FLOOR ZONE

Location: Vented attic

Cooling: 10 SEER (electric)

Heating: 80 AFUE (natural

gas)

\section{WATER HEATER: 0.58 EF}

\section{INITIAL DIAGNOSTIC}

\section{RESULTS}

HERS: 104

HESCORE: 5

AIR INFILTRATION: 6,567

$\mathrm{CFM}_{50}\left(14.7 \mathrm{ACH}_{50}\right)$

DUCT LEAKAGE TO OUTSIDE:

$1^{\text {st }}$ floor: 677 CFM $_{25}$

$2^{\text {nd }}$ floor: $105 \mathrm{CFM}_{25}$

DUCT INSULATION: R-5 and R8

COMBUSTION SAFETY TEST: All the units passed

a potential retrofit candidate to achieve energy savings of $30-50 \%$. Since the homeowners were interested in understanding the energy saving impact of the various measures they would take, they willingly agreed to participate in the study.

A one year profile of utility bills is shown in Figure 60. The annual electricity costs are approximately $\$ 1,600$, while the annual gas costs are approximately $\$ 1,200$. With a total site energy consumption of 129

MMBtu, this home uses slightly less than typical homes in the southeast of this size ${ }^{31}$ (150 MMBtu).

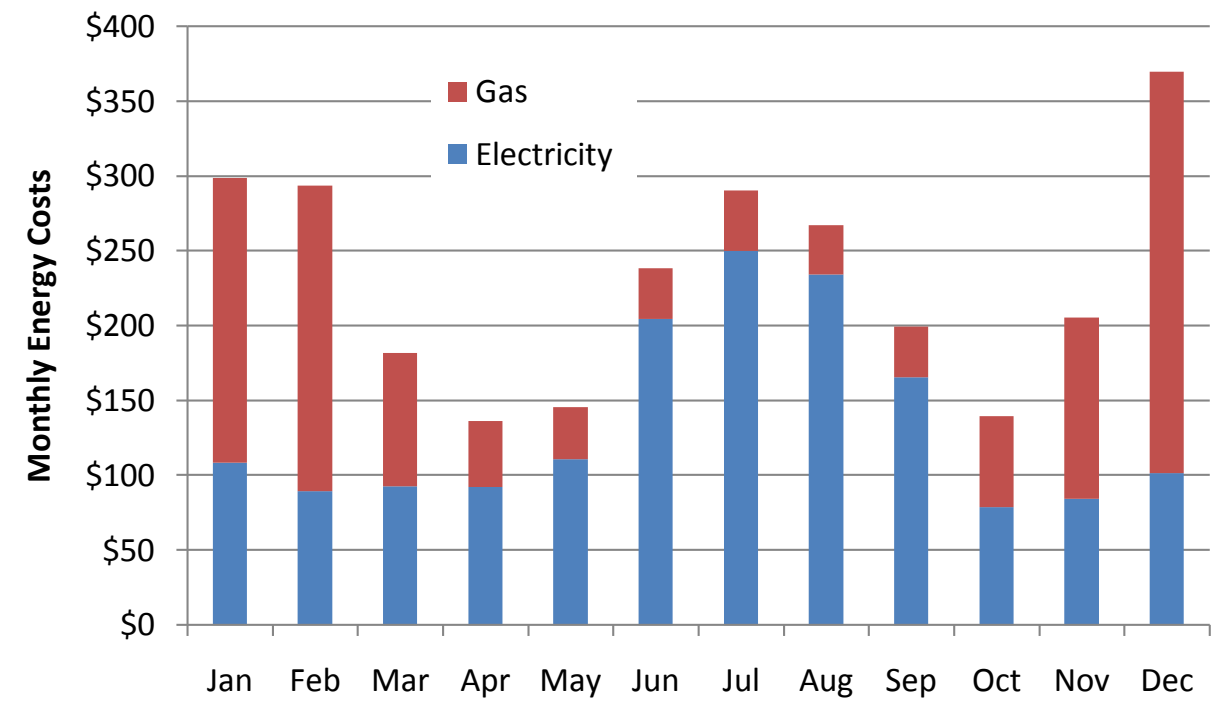

Figure 60. Yellow Jackets Monthly Energy Costs

Based on an initial homeowner interview, the average temperature set point during the cooling season is $78^{\circ} \mathrm{F}$. During the heating season, the average temperature set point is $68^{\circ} \mathrm{F}$. By contrast, the operating conditions for the Building America House Simulation Protocol are $76^{\circ} \mathrm{F}$ for the cooling season and $71^{\circ} \mathrm{F}$ for the heating season. Since the temperature set points contribute significantly to the overall building energy consumption, the below average pre-retrofit energy consumption of Yellow Jackets is expected.

\section{Yellow Jackets Initial Characteristics}

\section{Envelope Profile}

\footnotetext{
${ }^{31}$ Per the 2010 Buildings Energy Data Book, energy consumption for the South Atlantic region is $47.4 \mathrm{kBtu}$ per square foot.
} 
The building envelope is bounded by a framed floor above the vented crawlspace and an insulated ceiling plane above the second floor. Shown in Figure 61 is an illustration of the initial envelope profile. The dark green color in the figure represents the attic knee walls of the home. As seen in the figure, the FROG has significant knee wall exposure. While R-13 batts were used as knee wall insulation, there were many cases where batts were missing (Figure 62). When viewed in light of the fact that no insulation exists between the garage ceiling and the FROG floor, the low level of comfort experienced by the homeowners is expected. There was also no insulation in the wall separating the garage from the living space.

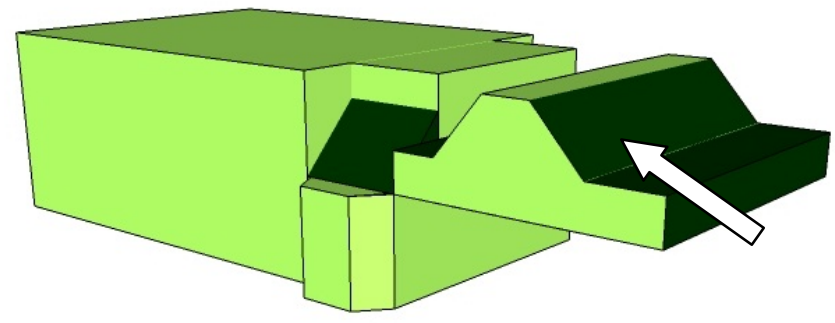

Figure 61. Yellow Jackets initial envelope profile. The arrow highlights the location of the FROG.

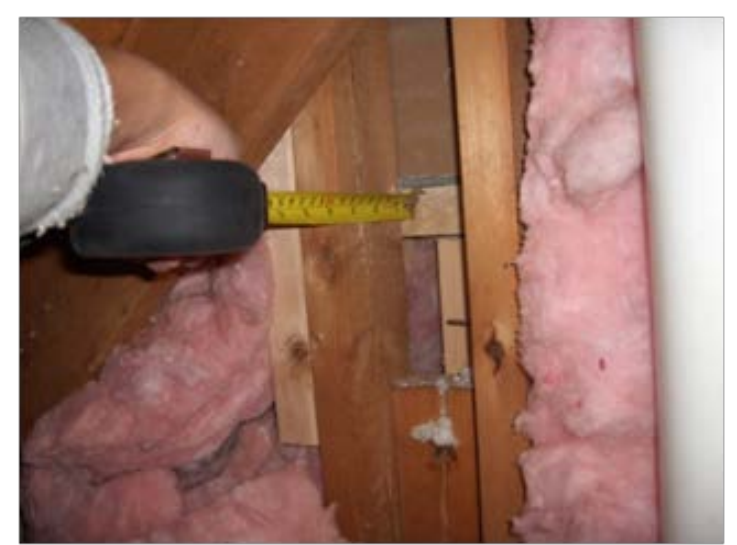

Figure 62. Void in attic knee walls

To aid in the building assessment, thermal infrared imaging was done. The assessment was performed as early in the morning as permitted by the homeowner (around 7:00 a.m.) before the building gained a great amount of solar load from the rising sun. Through the thermal scan and visual inspection of the house, insulation could be seen in exterior walls. Shown in Figure 63a is a sample thermal image where insulation was evident. Areas where the insulation had sunk over time can also be seen in the image below the window. Major leakage pathways were also identified around other windows and from the attic through the interior walls (Figure 63). 

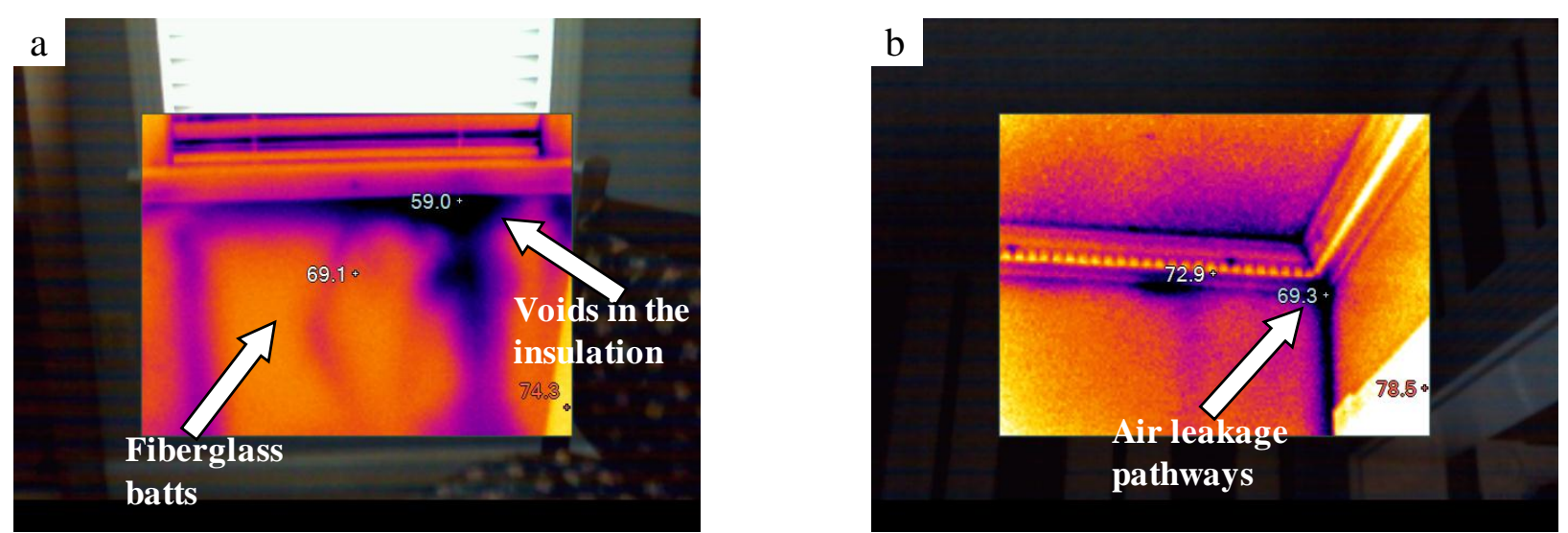

Figure 63. a) Thermal scan of an exterior wall. Voids in the insulation where the fiberglass batts have sunk over time is illustrated by the arrow. b) Thermal scan of an interior wall.

The homeowner mentioned that attic insulation was added twice since moving in; however, there was no attention to air sealing made, as evidenced in Figure 63b. There were also several chases, such as the furnace chase, which were not capped (Figure 64). These air leakage pathways contributed to the overall house air infiltration of approximately 6,567 $\mathrm{CFM}_{50}$, or $15 \mathrm{ACH}_{50}$.

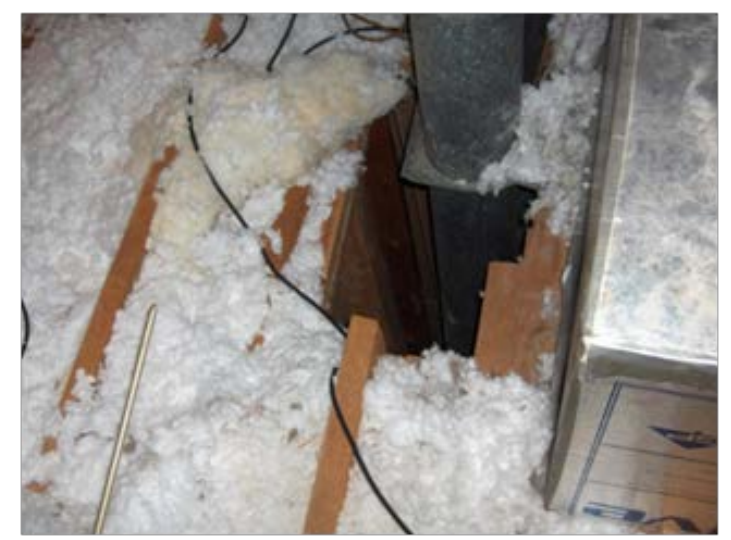

Figure 64. Open furnace chase in attic.

\section{HVAC}

The home had two HVAC units, both located outside the building envelope. The first floor was served by a 3 ton air conditioner with a 12 SEER rating. The gas furnace had a heating capacity of $100 \mathrm{kBtuh}$ with an 80 AFUE rating. The ducts were minimally insulated from R-5 to R-6 and were located in the unconditioned, unfinished basement along with the furnace. The duct leakage to the outside for this system was about $680 \mathrm{CFM}_{25}$, or $48 \%$ of the square footage served by the duct system. The second floor was served by a 3 ton air conditioner with a 10 SEER rating. The gas furnace was similar to the first floor furnace with a heating capacity of 100 kBtuh with an 80 AFUE rating. Both the furnace and ducts, insulated to levels of approximately R-5 to R-6, are located in the attic. The duct leakage to the outside for the second floor system was about $105 \mathrm{CFM}_{25}$, or $6 \%$ of the square footage served by the duct system.

\section{Lighting, Water Heating, Appliances}


The gas water heater was located in the unfinished, unconditioned basement. It had a storage capacity of 50 gallons and was rated at $0.59 \mathrm{EF}$. Additionally, the unit was insulated with a water heater blanket. The house had 45\% CFL lighting and no ENERGY STAR appliances. Both the range and oven were electric.

\section{Health and Safety}

A thorough combustion safety test was performed on both furnaces and the water heater. While the units are considered to be outside of the envelope (i.e. in the basement and attic), major air leakage pathways exist that connect the area to the living space. Both units passed all components of the combustion safety test: spillage, draft, and CO. 


\section{Retrofit Measures}

The contractor and the homeowner already had a tentative retrofit package determined when the project was recommended as a retrofit study candidate. The retrofit packaged included measures such as 1) upgrading the HVAC system in the attic, 2) sealing and insulating the roofline, 3) sealing and insulating the garage ceiling, 4) sealing and insulating the wall separating the garage and living space, and 5) duct sealing. Even though these improvements were already planned by the contractor and homeowner, a priority list of retrofit measures was determined based on the prioritization protocol used in this retrofit study (Table 1).

Table 34. Yellow Jackets priority list

\begin{tabular}{|c|c|c|}
\hline Improvement & Existing condition & Priority \\
\hline Air sealing & $\sim .91 \mathrm{ACH}_{\text {natural }} 32$ & A \\
\hline Improve ducts & $\begin{array}{l}\text { 6\% duct leakage (second floor) } \\
48 \% \text { duct leakage (first floor) }\end{array}$ & $\begin{array}{l}\mathrm{D} \\
\mathrm{A}\end{array}$ \\
\hline $\begin{array}{l}\text { Insulate ATTIC (attic floor air sealing must } \\
\text { precede insulation work) }\end{array}$ & $\mathrm{R}-24$ & $\mathrm{C}$ \\
\hline Insulate ATTIC KNEE WALLS & $\begin{array}{l}\text { Insulated, unsheathed or incomplete } \\
\text { sheathing }\end{array}$ & B \\
\hline Insulate FLOOR & None & B \\
\hline $\begin{array}{l}\text { Insulate BASEMENT/CRAWLSPACE } \\
\text { WALLS }\end{array}$ & None & B \\
\hline Radiant barrier & No radiant barrier & $\mathrm{D}$ \\
\hline Replace heating system & $\begin{array}{l}80 \text { AFUE }\left(2^{\text {nd }} \text { floor }\right) \\
80 \text { AFUE (1st) }\end{array}$ & $\begin{array}{l}\mathrm{C} \\
\mathrm{C}\end{array}$ \\
\hline Replace cooling system & $\begin{array}{l}\left.10 \text { SEER ( } 2^{\text {nd }} \text { floor }\right) \\
12 \operatorname{SEER}\left(1^{\text {st }} \text { floor }\right)\end{array}$ & $\begin{array}{l}C \\
D\end{array}$ \\
\hline Replace water heater & 0.59 gas & $\mathrm{C}$ \\
\hline Insulate water heater and pipe & Gas & $\mathrm{C}$ \\
\hline Improve windows & Vinyl-Double Pane & $\mathrm{D}$ \\
\hline
\end{tabular}

In the final package, items listed in the proposed contract were combined with measures that received a priority of A or B from the prioritization protocol listed in Table 34. Retrofit measures are described in the following text.

\section{Envelope}

Before any of the energy efficiency measures were taken, the homeowners replaced the existing roof and siding. A house wrap was applied as well (Figure 65) to address moisture management. The siding was replaced with fiber cement HardiePlank ${ }^{\circledR}$ lap siding. While these activities were completed prior to the retrofit study beginning, replacing the existing roof enabled the consideration of encapsulating the attic with spray foam on the roofline. It is not advisable to apply spray foam to existing roofs that may not adequately provide a barrier to bulk water transport.

\footnotetext{
${ }^{32} \mathrm{ACH}_{\text {natural }}=\mathrm{ACH}_{50} / \mathrm{N}_{\text {corrected }}$, where $\mathrm{N}_{\text {corrected }}$ is the height-corrected LBL "N-factor" (http://www.bpi.org/Web\%20Download/BPI\%20Standards/Building\%20Analyst\%20Professional_2-28-05nNCnewCO.pdf)
} 


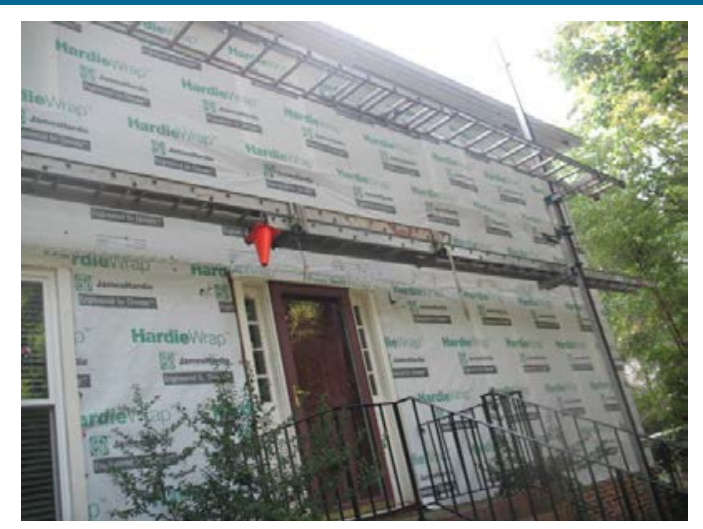

Figure 65. House wrap applied to Yellow Jackets before siding

The attic was encapsulated by applying more than 6” of open-cell spray foam to the rafters such that a continuous layer is formed over the $2 \times 6$ rafters to mitigate thermal bridging. Because the roofline was insulated, the thermal and pressure boundary now exist at the roof. As a result, the attic is now considered semi-conditioned volume and can be included in the building's total conditioned volume. This results in an additional 11,248 $\mathrm{ft}^{3}$ added to the conditioned volume. Additionally, the knee walls that previously existed and contributed to reduced thermal comfort are now brought into the semi-conditioned space. Figure 66 shows the 3-D model of the new envelope with the added attic volume. Because the homeowners plan to finish the basement in the future, supply registers were added to the basement. Consequently, the basement is also now a part of the conditioned volume. The band joist in the basement was also spray foamed with 3” open-cell (R-11).

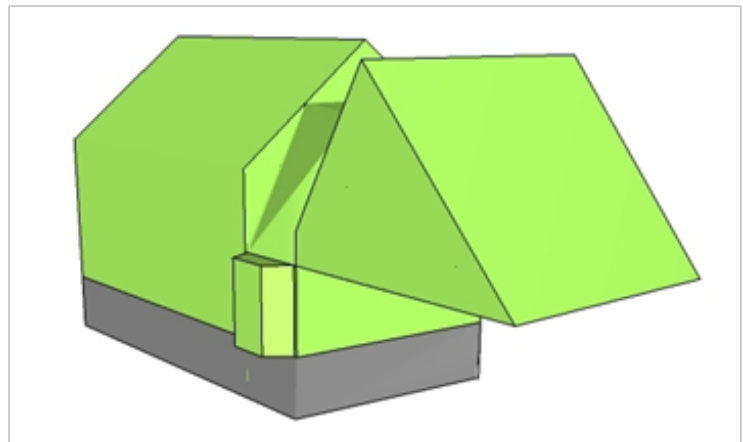

Figure 66. Yellow Jackets post-retrofit envelope profile. The gray in the photo represents the basement volume.

Previously, the wall separating the living space and the garage was uninsulated with significant air leakage pathways. As a part of the retrofit, the pressure and thermal boundary between the garage and living space were reinforced by applying approximately 3” open-cell spray foam (R11) insulation into the $2 x 4$ wall cavity and 5 ” open-cell spray foam (R-18) in the garage ceiling (Figure 21). The drywall on the garage wall and ceiling were removed prior to applying the spray foam insulation. A photograph of the spray foam insulation in the walls and ceiling is shown in Figure 67. 


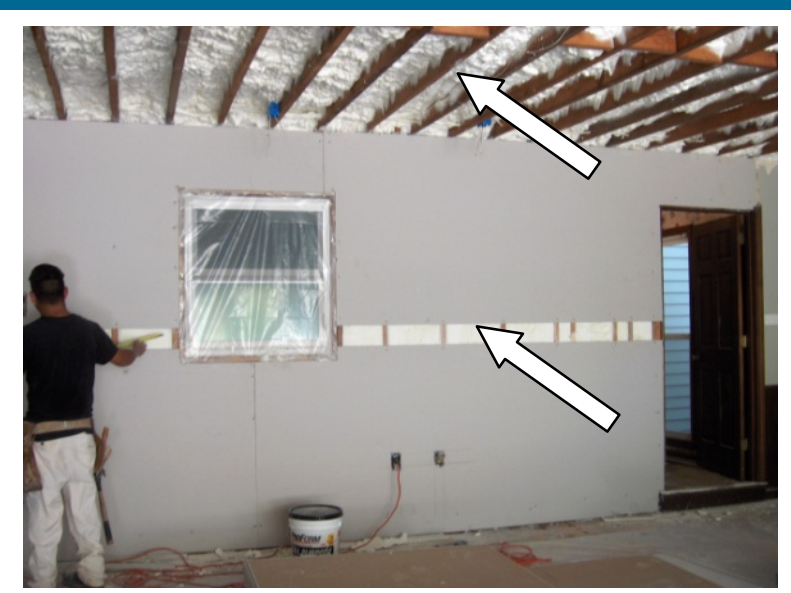

Figure 67. Insulated and sealed garage wall and ceiling. Arrows in the picture point to the spray foam in the wall cavities and in the garage ceiling.

\section{HVAC}

The HVAC unit which served the second floor was replaced with a 3 ton, 14 SEER A/C. The heating unit was replaced with a $70 \mathrm{kBtuh} 95$ AFUE sealed-combustion gas furnace. Because the gas furnace was located in the attic that is now semi-conditioned, combustion safety risks were mitigated by installing the sealed combustion unit. Per the request of the homeowner, a return was added to each of the four bedrooms. New R-8 insulated flex duct runs were installed along with the new system. Since the roofline has been insulated and sealed, the ducts for this particular system are now considered inside of the building envelope, such that air loss through duct leakage will be contained in the living space.

The first floor unit was not upgraded per homeowners' request. They did, however, try to seal the existing ductwork and added intentional supplies into the basement to bring this space and ducts into the conditioned building envelope volume. They are intending to create this space into a finished basement later.

\section{Lighting, Water Heating, Appliances}

The water heater was upgraded to an A.O. Smith Vertex water heater, which is a power-vented high-efficient gas water heater. Per the prioritization protocol used in this study, replacing the water heater only received a C priority. However, the water heater was located in the basement, which was brought inside of the building envelope as a part of this retrofit project. Installing a power-vent water heater was needed to mitigate combustion safety risks that could arise. Therefore, the water heater installation served the dual purpose of eliminating risks of combustion safety in a conditioned space, while also providing increased energy savings.

\section{Health and Safety}

Combustion safety issues were addressed by replacing the atmospherically vented water heater and furnace to both sealed-combustion units. The gas lines were replaced.

\section{Simulated Energy Savings}

Table 35shows the simulated energy savings from the implemented measures. In total, we estimate approximately an $18 \%$ reduction in source energy consumption. The estimated source 
energy savings are below the desired 30\% target of this study. However, this is due in part to the pre-retrofit estimated site energy of $135 \mathrm{MMBtu}$ which is below the average energy consumption of similarly sized homes in the South Atlantic census region. As can be seen in Figure 68, the energy savings for the primary building loads are all greater than $25 \%$. In spite of this, the estimated savings are only $18 \%$ in part because miscellaneous loads, such as appliances and lighting, which were not significantly addressed in this project, consume approximately $44 \%$ of the simulated building load.

Table 35. Yellow Jackets recommended package with simulated energy savings from EnergyGauge

\begin{tabular}{|l|r|r|r|r|}
\hline & \multicolumn{1}{|c|}{$\begin{array}{c}\text { Predicted } \\
\text { Site } \\
\text { Energy } \\
\text { (MMBtu) }\end{array}$} & $\begin{array}{c}\text { Predicted } \\
\text { Source } \\
\text { Energy } \\
\text { (MMBtu) }\end{array}$ & $\begin{array}{c}\text { Site } \\
\text { Energy Savings } \\
\text { (\% per measure) }\end{array}$ & $\begin{array}{c}\text { Source } \\
\text { Energy Savings } \\
\text { (\% per measure) }\end{array}$ \\
\hline $\begin{array}{l}\text { Yellow Jackets Simulated } \\
\text { Energy Use }\end{array}$ & 135 & 244 & $16 \%$ & $11 \%$ \\
\hline + Envelope Improvements & 114 & 216 & $6 \%$ & $4 \%$ \\
\hline $\begin{array}{l}\text { ++ HVAC System } \\
\text { Improvements }\end{array}$ & 106 & 205 & $4 \%$ & $2 \%$ \\
\hline $\begin{array}{l}\text { +++ Water Heater } \\
\text { Improvements }\end{array}$ & 101 & 199 & $25 \%$ & $18 \%$ \\
\hline Total Retrofit Investment & & & & \\
\hline
\end{tabular}

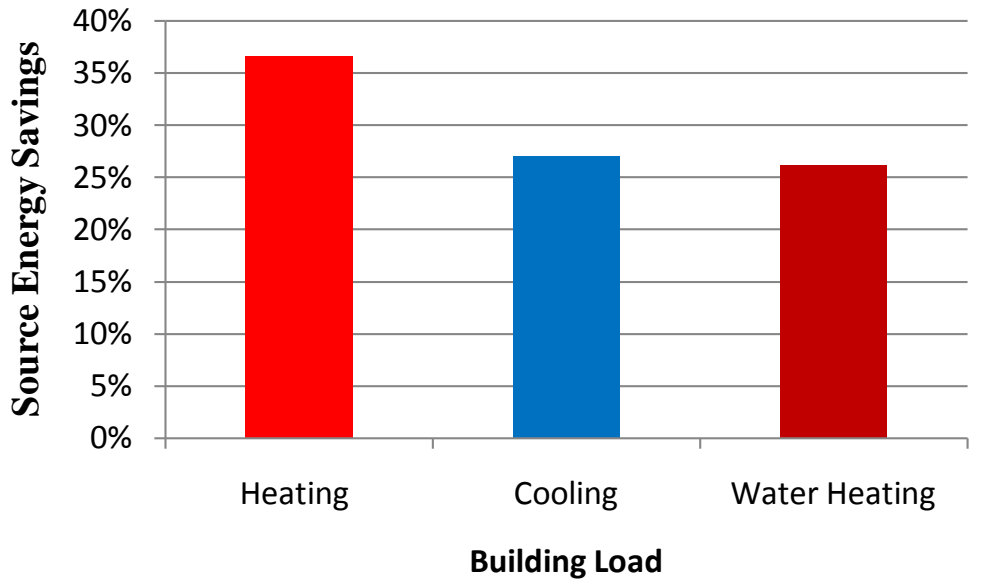

Figure 68. Simulated Energy Savings from Primary Building Loads

\section{Diagnostics and Test Out}

After all retrofit measures were completed, a test-out of Yellow Jackets was performed. Salient test-out diagnostics are shown in Table 36 and Table 27. The air sealing measures performed on the building envelope were able to yield an approximately 50\% decrease in air infiltration. This is primarily due to 1) spray foam applied on the roofline to seal the attic, 2) spray foam applied in the wall cavities separating the garage from the living space, and 3) spray foam applied in the garage ceiling to insulate and seal the FROG. 
Table 36. Pre-retrofit and post-retrofit air infiltration diagnostics

\begin{tabular}{|l|c|c|l|}
\hline \multicolumn{4}{|l|}{$\begin{array}{l}\text { Infiltration - } \\
\text { Notes: } \mathrm{ACH}_{50} \text { is }\left(\mathrm{CFM}_{50} * 60\right) / \text { conditioned volume }\left(\mathrm{ft}^{3}\right)\end{array}$} \\
\cline { 2 - 4 } Pre-Retrofit & 6,567 & 14.7 & Initial Building Volume: 26,767 $\mathrm{ft}^{3}$ \\
\hline Post-Retrofit & 3,393 & 5.4 & $\begin{array}{l}\text { Final Building Volume (basement } \\
\text { volume has been added to reflect the } \\
\text { additional conditioned space): }\end{array}$ \\
\hline \% Reduction & $48 \%$ & $70 \%$ & \\
\hline
\end{tabular}

When an attic is encapsulated, the retrofit measures are often described as insulating the roofline and sealing the attic. However, in some home energy retrofits, terminology such as "sealing the attic" should be used and understood with care. It is not clear, that spray foam installers are able to perfectly seal all attics that are "sealed". Because of the questions the researchers in this study had concerning the level of "attic sealing” that occurs in retrofits, Blower Door tests were conducted with the attic access door closed and with the attic access open. In the former test case, the attic is only partially connected to the house through leakage pathways in the ceiling and in ducts located in the attic. However, in the latter case where the attic access is open, the attic volume is now better connected to the house such that additional building infiltration can be likely attributed to the attic volume. If the attic is sealed from the exterior, there should be little to no additional infiltration when the attic access is opened. In the case of Yellow Jackets, there was no appreciable difference between Blower Door tests with the attic access closed and with it opened. This suggests that the attic is effectively sealed from the exterior. Dataloggers will be placed in the attic so that temperature and humidity levels in the attic volume can be monitored and compared with other houses with encapsulated attics.

The duct systems showed some improvements after retrofit work was completed, particularly on the second floor system where the entire HVAC system was replaced. However, the air leakage in the ducts that serve the first floor increased after the retrofit, even though the homeowner paid to have the ducts sealed. This could be due to additional leakage induced when supply registers were added to the basement. At the time of this report's release, the contractor is evaluating what can be done.

Table 37. Pre-retrofit and post-retrofit duct leakage diagnostics - duct leakage to outside measured as air flow at $25 \mathrm{~Pa}\left(\mathrm{CFM}_{25}\right)$ and normalized as a percentage $\left(\mathrm{CFM}_{25} /\right.$ conditioned area $\left.\left(\mathrm{ft}^{2}\right)\right)$

\begin{tabular}{|c|c|c|c|c|}
\hline & \multicolumn{2}{|c|}{$\begin{array}{c}\text { System 1* } \\
\text { (second floor) }\end{array}$} & \multicolumn{2}{c|}{$\begin{array}{c}\text { System 2** } \\
\text { (first floor) }\end{array}$} \\
\hline & CFM $_{25}$ & \% Leakage to Outside & CFM $_{25}$ & \% Leakage to Outside \\
\hline Initial & 105 & $6 \%$ & 677 & $48 \%$ \\
\hline Post & 0 & $0 \%$ & 708 & $25 \%$ \\
\hline $\begin{array}{c}\text { \% } \\
\text { Reduction }\end{array}$ & $100 \%$ & $100 \%$ & $-5 \%$ & $47 \%$ \\
\hline
\end{tabular}

$*$ The conditioned area of system 1 is equal to $1,745 \mathrm{ft}^{2}$.

** The pre-retrofit conditioned area that system 2 serves is equal to $1,423 \mathrm{ft}^{2}$. The post-retrofit conditioned area that system 2 serves is equal to $2,831 \mathrm{ft}^{2}$. The increase is due to the additional basement area. 
Overall the final HERS index improved from 104 to 73 . While the home is expected to only achieve approximately $20 \%$ in source energy savings, a post-retrofit HERS index of 73 is a good final outcome of this retrofit. In FY12, whole-house energy consumption, along with the contribution of major loads such as the air conditioner, will be submetered by an e-Monitor device installed in May 2011. Additionally, utility bills will continue to be collected for comparison with pre-retrofit utility bills.

\section{Yellow Jackets Cost and Scope of Work}

The total improvements for this home are about $\$ 21,620$. This cost does not reflect the siding or roof replacement. Table 38 provides the final scope of work and breakdown of the costs. If the costs of existing sheetrock demolition, material disposal, and sheetrock replacement are included, the total costs are $\$ 27,720$.

Table 38. Yellow Jackets final scope of work and costs

\begin{tabular}{|c|c|c|c|}
\hline Home Characteristics & Existing Conditions & Measures & Proposed Costs \\
\hline Exterior Walls & R-11 fiberglass batts & $\begin{array}{c}\text { R-18 open-cell } \\
\text { spray foam on } \\
\text { garage ceiling/ } \\
\text { R-11 on the garage } \\
\text { wall }\end{array}$ & \multirow{4}{*}{$\begin{array}{c}\$ 12,880 \\
\text { (cost includes all } \\
\text { insulation and air } \\
\text { sealing measures for all } \\
\text { envelope measures) }\end{array}$} \\
\hline $\begin{array}{c}\text { Attic/ } \\
\text { Knee walls }\end{array}$ & $\begin{array}{l}\text { R-24 blown fiberglass flat } \\
\text { ceiling/ } \\
\text { R-13 fiberglass batts }\end{array}$ & $\begin{array}{l}\mathrm{R}-21 \text { open-cell } \\
\text { spray foam on the } \\
\text { roofline }\end{array}$ & \\
\hline Foundation Ceiling & $\mathrm{R}-0$ & N/A & \\
\hline Foundation Walls & $\mathrm{R}-0$ & $\begin{array}{l}\text { R-11 open-cell } \\
\text { spray foam on } \\
\text { basement band }\end{array}$ & \\
\hline Cooling & $\begin{array}{l}\left.3 \text { ton } 12 \text { SEER ( } 1^{\text {st }} \text { Floor }\right) \\
\left.3 \text { ton } 10 \text { SEER ( } 2^{\text {nd }} \text { Floor }\right)\end{array}$ & $\begin{array}{c}\left.\text { N/A (1 } 1^{\text {st }} \text { Floor }\right) \\
3 \text { ton } 14 \text { SEER }\left(2^{\text {nd }}\right. \\
\text { Floor }) \\
\end{array}$ & \multirow{2}{*}{$\begin{array}{l}\$ 7,211\left(2^{\text {nd }} \text { Floor }\right) \\
\$ 980\left(1^{\text {st }} \text { Floor }\right) \\
\text { Includes: duct sealing, } \\
\text { new R-8 insulated flex } \\
\text { ducts for the } 1^{\text {st }} \text { floor, } \\
\text { two supply registers } \\
\text { added to the basement, } \\
\text { and four additional } \\
\text { returns on the second } \\
\text { floor }\end{array}$} \\
\hline Heating & $\begin{array}{c}100 \text { kBtuh } 80 \text { AFUE } \\
\left(1^{\text {st }} \text { Floor }\right) \\
100 \text { kBtuh } 80 \text { AFUE } \\
\left(2^{\text {nd }} \text { Floor }\right)\end{array}$ & $\begin{array}{c}\text { N/A ( }\left(1^{\text {st }} \text { Floor }\right) \\
70 \text { kBtuh } 95 \text { AFUE } \\
\left(2^{\text {nd }} \text { Floor }\right)\end{array}$ & \\
\hline DHW & $.57 \mathrm{EF}$ & A.O. Smith Vertex & $\begin{array}{l}\text { Donated by A.O. Smith } \\
\quad \text { (MSRP = \$2,600); } \\
\text { \$1,150 for installation }\end{array}$ \\
\hline Windows & Double-Pane Vinyl & N/A & N/A \\
\hline
\end{tabular}




\section{Eagle}

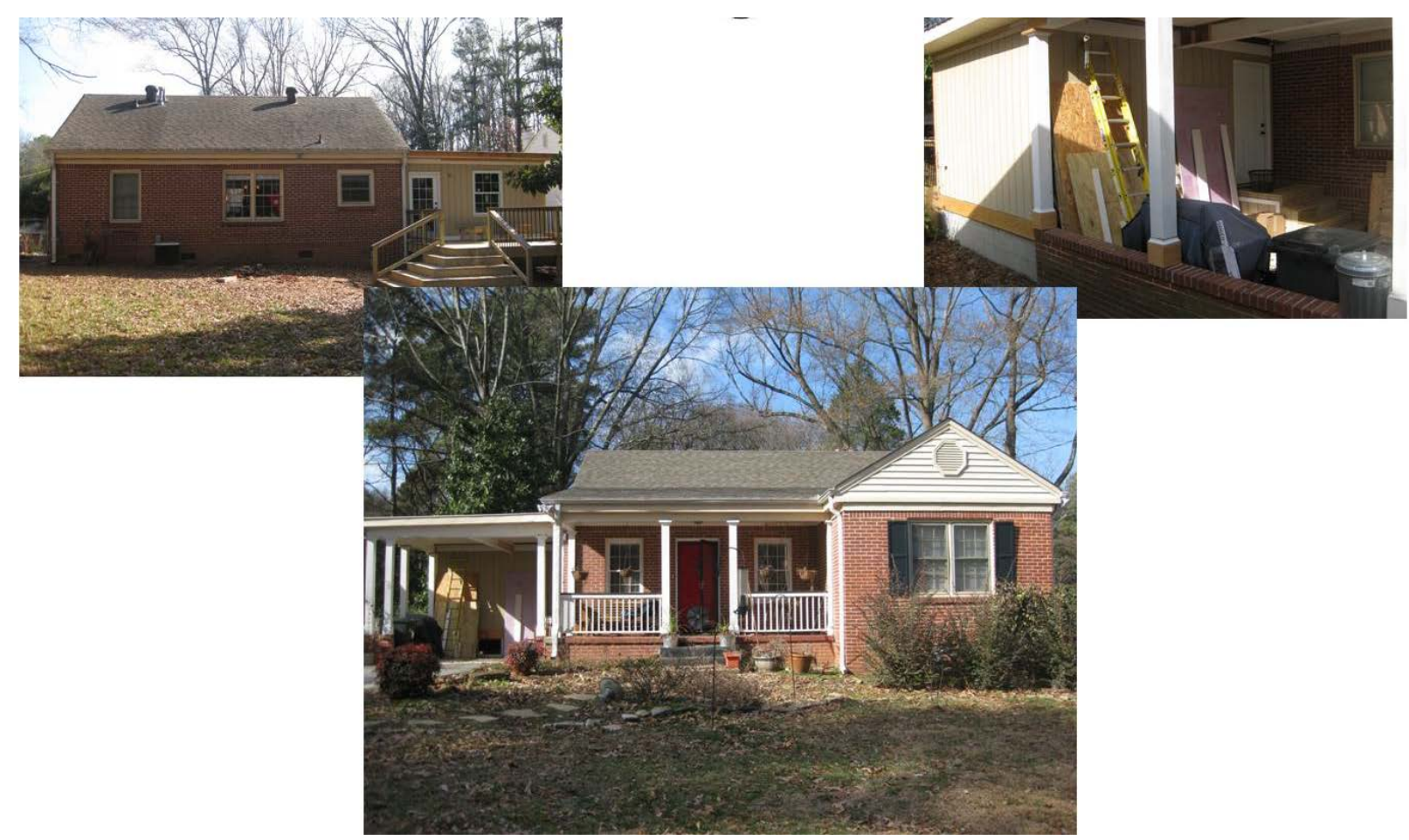

\section{Eagle Home Profile}

Originally built in 1955, Eagle is a one story, single-family ranch home with $1,320 \mathrm{ft}^{2}$ of living area. There are two bedrooms and one bathroom. Eagle has a traditional vented attic and a vented crawlspace. A family of two adults lives in this home.

The family's energy costs from December 2009- November 2010 are shown in Figure 69Figure 27. With a total annual cost of $\$ 2,450$ (103 MMBtu of site energy), the family's energy costs are higher than the average annual site energy consumption for a typical home in the southeast of this size (63 $\mathrm{MMBtu}^{33}$ ). While higher than average, the family's energy costs are tempered since they actively use a programmable thermostat. Temperature set points are shown in Table 39.

Eagle's homeowner initially had plans to add additional living area to his home. He was going to convert a portion of the storage room into a laundry room while also creating a conditioned closet in the attic. After learning of the study that ORNL and Southface were conducting to validate energy savings of specific retrofit measures with a goal of a 30-50\% reduction, the homeowner decided to go forward with other energy efficient measures he was considering. These measures included removing the HVAC system from the attic and replacing with a more efficient system in the crawlspace, along with adding more attic insulation. While he had initially planned on implementing these measures in stages in the future, he considered it

\footnotetext{
${ }^{33}$ Per the 2010 Buildings Energy Data Book, energy consumption for the South Atlantic region is 47.4 kBtu per square foot.
} 
worthwhile to do them now to participate in the study to better understand the impact of the measures he wanted to employ.

The authors of this report believe that deep energy retrofits, like the type evaluated in this study will likely occur in conjunction with other home improvements such as remodeling, additions, and repair. Therefore, this type of "event triggered" deep energy retrofit will be important to investigate and understand.

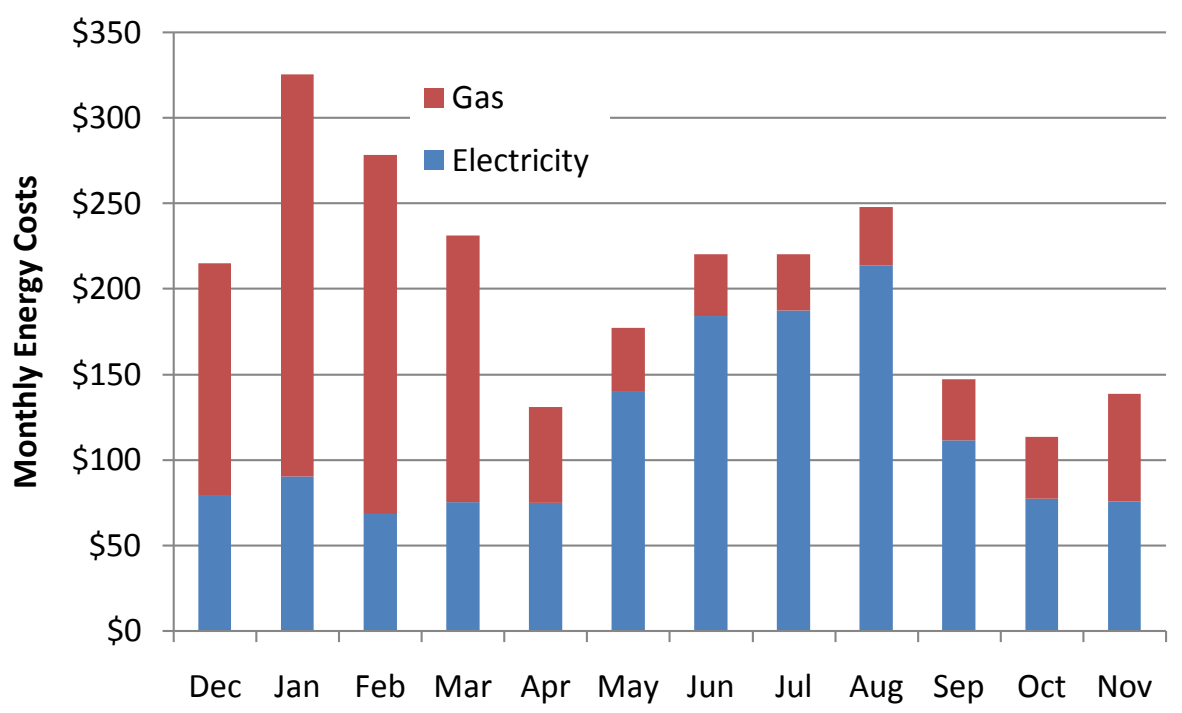

Figure 69. Eagle monthly energy costs

Table 39. Temperature set points for Eagle

\begin{tabular}{|c|c|c|c|}
\hline \multicolumn{2}{|c|}{ Cooling } & \multicolumn{2}{c|}{ Heating } \\
\hline Time & $\begin{array}{c}\text { Set point } \\
\left({ }^{\circ} \mathrm{F}\right)\end{array}$ & Time & $\begin{array}{c}\text { Set point } \\
\left({ }^{\circ} \mathrm{F}\right)\end{array}$ \\
\hline $8: 00-17: 00$ & 82 & $8: 00-17: 00$ & 63 \\
\hline $17: 00-21: 00$ & 78 & $17: 00-21: 00$ & 68 \\
\hline $21: 00-8: 00$ & 70 & $21: 00-8: 00$ & 66 \\
\hline
\end{tabular}

\section{Eagle Initial Characteristics}

\section{Envelope Profile}

Eagle has a basic envelope profile, as illustrated in Figure 70. The ceiling heights are $8 \mathrm{ft}$ throughout the home. The envelope is bounded by an un-insulated framed floor above the vented crawlspace and an insulated ceiling plane above the first floor. The windows are all single pane windows with wood frames. In the initial envelope, the planned additions to home were not included. 
EAGLE PRE-RETROFIT

CHARACTERISTICS

TYPE: One-story, single-family

home

SIZE: $1,320 \mathrm{ft}^{2}$

Occupancy: Two adults

\section{INITIAL ENVELOPE}

\section{PROFILE}

WALL INSULATION: NONE

FOUNDATION BAND

INSULATION: None

ATtIC INSULATION: R-11

\section{INITIAL MECHANICAL}

\section{PROFILE}

Location: attic

Cooling: 9 SEER (electric)

Heating: 76 AFUE (natural

gas)

WATER HEATER: 0.59 EF

(natural gas)

\section{INITIAL DiAgNOSTIC}

\section{RESULTS}

HERS: 160

HESCORE: 6

AIR INFILTRATION:

3.111 CFM 50 (17.7 $\left.\mathrm{ACH}_{50}\right)$

DUCT LEAKAGE TO OUTSIDE:

$266 \mathrm{CFM}_{25}$

DUCT INSULATION: R-6

COMBUSTION SAFETY TEST: All

the units passed.

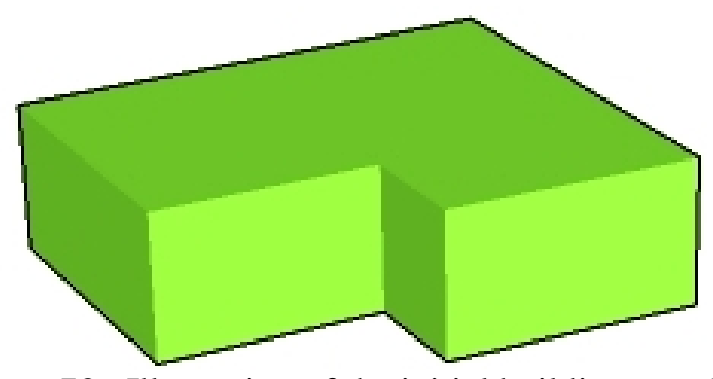

Figure 70. Illustration of the initial building envelope

Given the age of Eagle, exterior wall insulation was not expected. To aid in the building assessment, thermal infrared imaging was done. The assessment was performed as early in the morning as permitted by the tenant (around 7:00 a.m.) before the building gained a great amount of solar load from the rising sun. Through the thermal scan and visual inspection of the house, no insulation was evident in exterior walls.

In the attic, the ceiling had a combination of blown fiberglass and fiberglass batts. The average insulation coverage was equivalent to approximately R-20. There were no knee walls present in this home as the ceiling plane was one level and there were no dropped ceilings.

In the ceiling of the vented crawlspace (i.e. subfloor), there was no insulation. There was also no insulation in the band or foundation walls.

During the initial home energy assessment, a Blower Door test was conducted to evaluate the air infiltration. The total air leakage rate was $3,110 \mathrm{CFM}_{50}$. With a conditioned volume of $10,544 \mathrm{ft}^{3}$, the air exchange rate for Eagle was approximately $17.7 \mathrm{ACH}_{50}$. While the Blower Door was used to depressurize the house, thermal imaging was done to detect points of significant infiltration. Large infiltration was detected near the baseboards, under the kitchen cabinets, near windows, and over door headers (Figure 71).

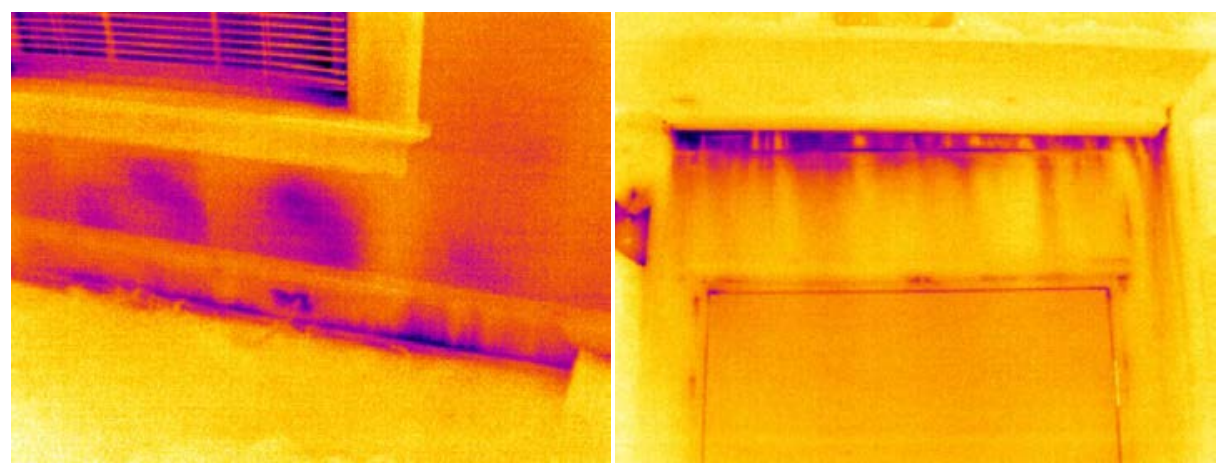

Figure 71. Thermal images that show significant air infiltration at baseboards (left) and door headers (right). 
HVAC

Conditioned air was provided in Eagle by a 2.5 ton capacity air conditioner, with an efficiency of 10 SEER. Heating for the home was provided by a natural gas furnace with a capacity of 55 $\mathrm{kBtuh}$ and a rating of 76 AFUE. About $60 \%$ of the ducts were insulated with R-6 insulation, while the remaining were insulated with R-8 insulation. The entire HVAC system was located in the attic. Duct leakage tests were performed and yielded a duct leakage of $270 \mathrm{CFM}_{25}$ or $20 \%$ of the conditioned floor area.

\section{Lighting, Water Heating, Appliances}

The gas water heater was located in a closet inside the building envelope. It had a storage capacity of 40 gallons and was rated at $0.59 \mathrm{EF}$. The house had no CFL lighting and no ENERGY STAR appliances. Both the range and oven were gas fueled.

\section{Health and Safety}

A thorough combustion safety test was performed on the water heaters, furnace, oven, and range. While the units are considered to be outside of the envelope (i.e. an exterior storage room), the major air leakage pathways connect the area to the living space. All units passed all components of the combustion safety test: spillage, draft, and CO. No gas leaks were detected. 


\section{Retrofit Measures}

Using the prioritization protocol for this retrofit study, the following retrofit priorities were determined.

Table 40. Eagle priority list

\begin{tabular}{|l|l|c|}
\hline \multicolumn{1}{|c|}{ Improvement } & \multicolumn{1}{c|}{ Existing condition } & Priority \\
\hline Air sealing & $\sim 0.89 \mathrm{ACH}_{\text {natural }}{ }^{4}$ & $\mathrm{~A}$ \\
\hline Improve ducts & $20 \%$ duct leakage & $\mathrm{B}$ \\
\hline $\begin{array}{l}\text { Insulate ATTIC (attic floor air sealing must } \\
\text { precede insulation work) }\end{array}$ & $\mathrm{R}-20$ & $\mathrm{C}$ \\
\hline Insulate WALLS & None & $\mathrm{C}$ \\
\hline Insulate FLOOR & None & $\mathrm{B}$ \\
\hline $\begin{array}{l}\text { Insulate BASEMENT/CRAWLSPACE } \\
\text { WALLS }\end{array}$ & None & $\mathrm{B}$ \\
\hline Radiant barrier & No radiant barrier & $\mathrm{D}$ \\
\hline Replace heating system & 76 AFUE & $\mathrm{B}$ \\
\hline Replace cooling system & 9 SEER & $\mathrm{A}$ \\
\hline Replace water heater & .59 gas & $\mathrm{D}$ \\
\hline Insulate water heater and pipe & Gas & $\mathrm{C}$ \\
\hline Improve windows & Wood single pane & $\mathrm{C}$ \\
\hline Improve windows & Wood single pane with storm & $\mathrm{D}$ \\
\hline
\end{tabular}

Measures that received a priority of A or B from the prioritization protocol listed in Table 40 were used as a basis for discussion with the homeowner on determining the final retrofit package. Retrofit measures included in the final package are described in the following text.

\section{Envelope}

As previously discussed, the homeowner decided to extend the building envelope by bringing the storage room into the conditioned area as well as building a conditioned closet in the attic. Photographs of the conditioned closet and the converted storage room area are shown in Figure 72 and Figure 73.

\footnotetext{
${ }^{34} \mathrm{ACH}_{\text {natural }}=\mathrm{ACH}_{50} / \mathrm{N}_{\text {corrected }}$, where $\mathrm{N}_{\text {corrected }}$ is the height-corrected LBL " $\mathrm{N}$-factor" (http://www.bpi.org/Web\%20Download/BPI\%20Standards/Building\%20Analyst\%20Professional_2-28-05nNCnewCO.pdf)
} 


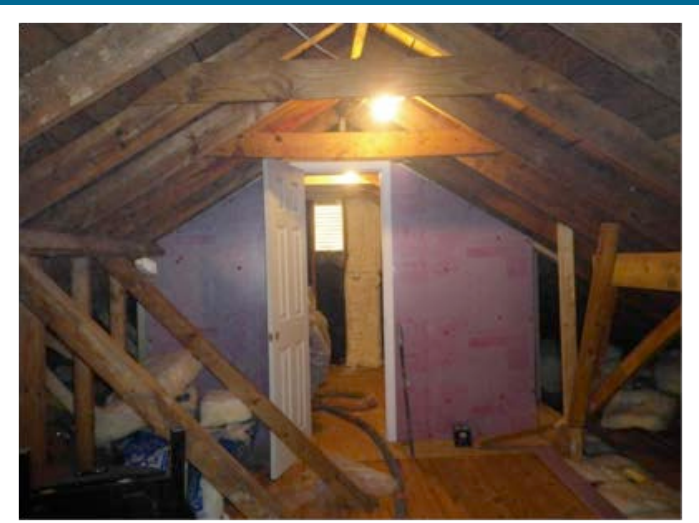

Figure 72. Photograph of the conditioned closet

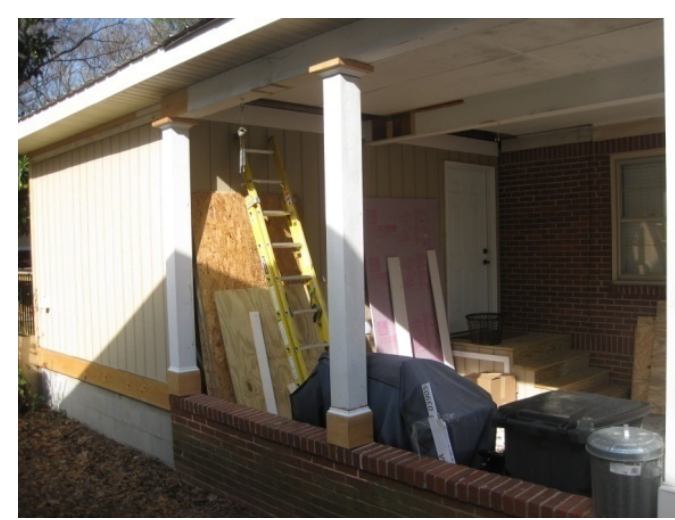

Figure 73. Photograph of the storage room area that has been converted to conditioned area.

With the conditioned closet area of $93 \mathrm{ft}^{2}$, along with the converted storage room area of $180 \mathrm{ft}^{2}$, the total conditioned area and volume of the post-retrofit home is $1591 \mathrm{ft}^{2}$ and $12,750 \mathrm{ft}^{3}$. The new building envelope is illustrated in Figure 74. The dark green color portrays the attic knee walls created by the attic conditioned closet.

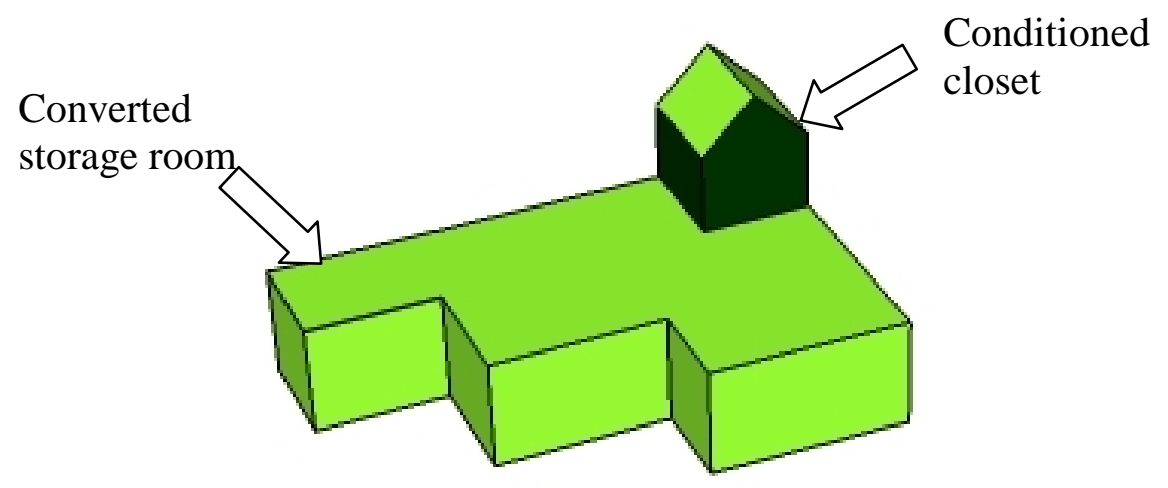

Figure 74. Illustration of the new building envelope after the addition area has been added.

The wall cavities of the additions to Eagle were both insulated with open-cell spray foam (R-15). A photograph of the insulation in the wall cavity and in the ceiling rafters is shown in Figure 75. The insulation value on the roofline in the conditioned closet shown in the picture is 
approximately R-19. In the converted storage room, an R-value of approximately R-18 (3”) in closed-cell spray foam was applied on the ceiling.

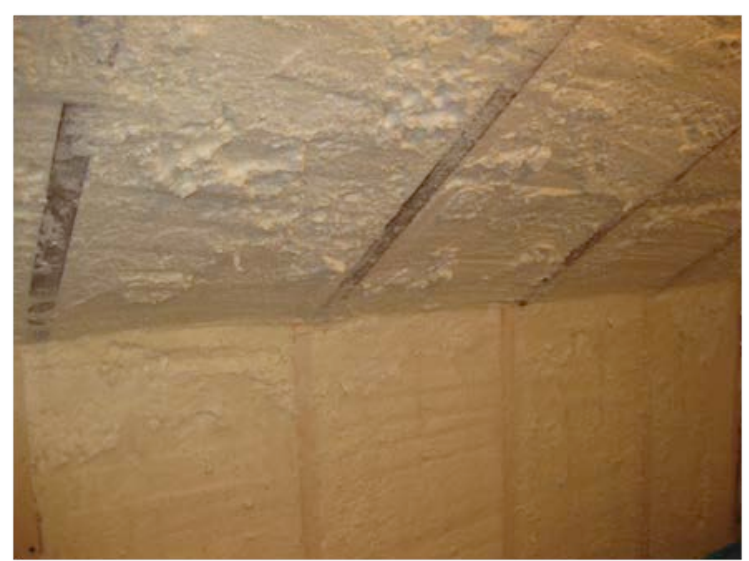

Figure 75. Photograph of open-cell spray foam in the wall cavities and ceiling rafters

A drill-and-fill technique was used to dense pack cellulose insulation into the previously uninsulated wall cavities. In each cavity, two holes of approximately 3” were drilled. One hole was drilled in the middle of the cavity, while the second hole was drilled near the top. The middle hole was filled first so that the cellulose insulation could fill the cavity from the bottom to the top. A photograph of both holes drilled in the wall is shown in Figure 76. The estimated Rvalue of the insulation is R-13. Because the retrofit was completed during the summer months, clear thermal images of the wall cavities after being filled with insulation was not feasible. However, further thermal imaging is planned once weather permits, in order to evaluate the grade of the insulation installation.

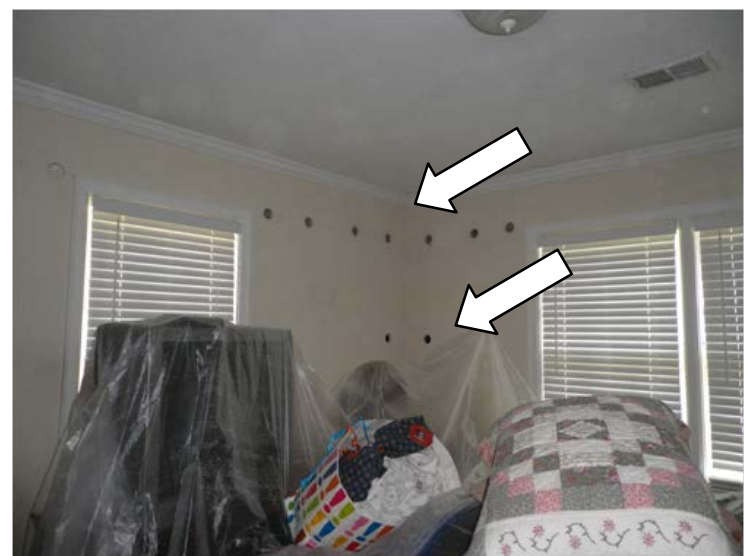

Figure 76. Holes drilled in the wall for cellulose installation

While insulating the walls was not listed as an A or B priority in the prioritization list (Table 1), the homeowner decided to include this measure as a part of the retrofit package. In addition to the reduced HVAC energy consumption that would be a product of wall cavity insulation, the homeowner noted the added "beyond-energy" benefit of increased thermal comfort afforded by this measure. Insulating the wall cavities would have the effect of reducing the mean radiant 
temperature (a common figure of merit for personal comfort), for a given temperature set point in the home. In other words, a room at an interior temperature of $73^{\circ} \mathrm{F}$ that has insulated exterior wall cavities would "feel" more comfortable to an occupant than a similar room at the same interior temperature but had no exterior wall cavity insulation.

In the crawlspace, approximately 3" of closed-cell insulation was sprayed on the band in order to provide air sealing in addition to thermal resistance (R-18). A photograph of the band insulation is shown in Figure 77. At the time this study was published, the crawlspace remains vented.

However, the homeowner is considering removing the vents in the foundation wall and ceiling to effectively encapsulate the crawlspace at a later time. When this is done, consideration will be given to applying insulation on the crawlspace walls.

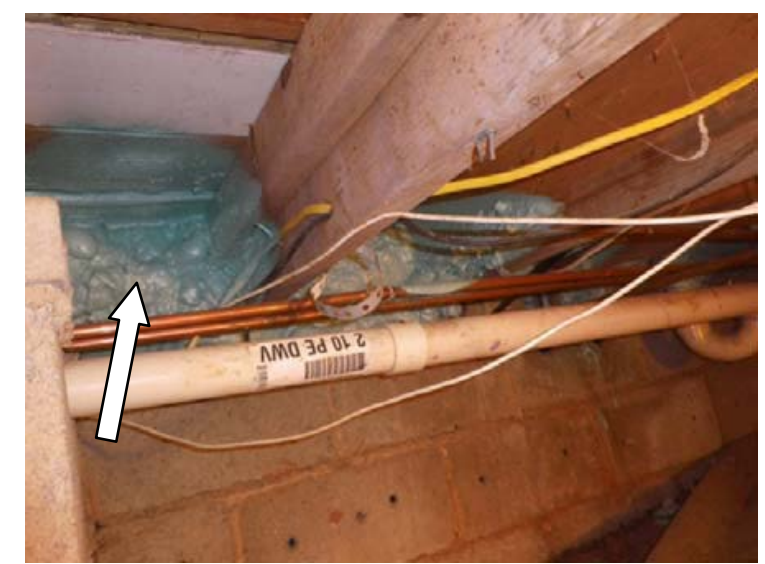

Figure 77. R-5 of closed-cell insulation sprayed on the band joist

\section{HVAC}

The air conditioning unit in Eagle was removed and replaced with a 18 SEER, 9.5 HSPF, 2 ton dual-fuel heat pump system. In order to eliminate ducts in the attic, the HVAC system was installed the crawlspace, which has a more moderate temperature than the attic. Since the homeowner is considering encapsulating the crawlspace, by relocating the HVAC system to the crawlspace, the system could be included within the building envelope in the future. Because the ductwork was relocated to the crawlspace, new floor registers were added. The original ceiling registers were capped and flash foamed.

In order to condition the closet that has been added (Figure 72), a transfer grill will be installed in the floor of the closet to the ceiling of the main living area.

\section{Lighting, Water Heating, Appliances}

No water heater, lighting, or appliance upgrades were made at the moment.

\section{Health and Safety}

No combustion safety remediation needed. 


\section{Simulated Energy Savings}

Table 41shows the simulated energy savings from the implemented retrofit measures. For modeling purposes and comparison with the pre-retrofit case, the additional area added to the building envelope was not modeled. Only the original area of $1,318 \mathrm{ft}^{2}$ was simulated. Additionally, the electric heat pump was assumed to meet the entire heating load, since EnergyGauge is not able to model dual fuel HVAC systems. This assumption therefore implies that electric strip heat will be used to supplement the heating load, instead of the gas furnace providing supplemental heat. Because the gas furnace is more efficient than electric strip heat, the energy savings shown in the table are likely underestimated in this regard.

Table 41. Eagle recommended package with simulated energy savings from EnergyGauge

\begin{tabular}{|l|l|r|l|l|}
\hline & $\begin{array}{l}\text { Predicted Site } \\
\text { Energy } \\
\text { (MMBtu) }\end{array}$ & $\begin{array}{l}\text { Predicted Source } \\
\text { Energy (MMBtu) }\end{array}$ & $\begin{array}{l}\text { Site Energy } \\
\text { Savings (\% per } \\
\text { measure) }\end{array}$ & $\begin{array}{l}\text { Source Energy } \\
\text { Savings (\% per } \\
\text { measure) }\end{array}$ \\
\hline $\begin{array}{l}\text { Eagle Simulated } \\
\text { Energy Use }\end{array}$ & 108 & 193 & $30 \%$ & $32 \%$ \\
\hline $\begin{array}{l}\text { + Envelope } \\
\text { Improvements }\end{array}$ & 76 & 130 & $23 \%$ & $0 \%$ \\
\hline $\begin{array}{l}\text { ++ HVAC System } \\
\text { Improvements }\end{array}$ & 51 & 131 & $53 \%$ & $32 \%$ \\
\hline $\begin{array}{l}\text { Total Retrofit } \\
\text { Investment }\end{array}$ & & & & \\
\end{tabular}

In total, there is an estimated 32\% reduction in source energy consumption. The predicted source energy savings from envelope improvements are 32\%. However, there are no source energy savings for the HVAC system improvement. This is due to the fact that the original HVAC system employed a gas furnace to meet all heating loads. In the simulated energy savings below, the electric heat pump is used to provide all heating and cooling loads. From a site energy perspective there are significant savings due to the increased efficiency of the air conditioning that is provided. However, the fuel switch in heating from gas to electric has a source energy penalty. When fuel switching is involved in a residential retrofit it is insightful to examine the site energy savings. In this case, the site energy savings for the HVAC system replacement and relocation to the crawlspace is approximately $23 \%$. In total, site energy savings of $53 \%$ are predicted for this retrofit.

As can be seen in Figure 78, the energy savings for the primary building loads are significant. The heating and cooling load source energy savings are $38 \%$ and $61 \%$, respectively. Conversely, from a site energy perspective, the heating and cooling load energy savings are $78 \%$ and $61 \%$, respectively. 


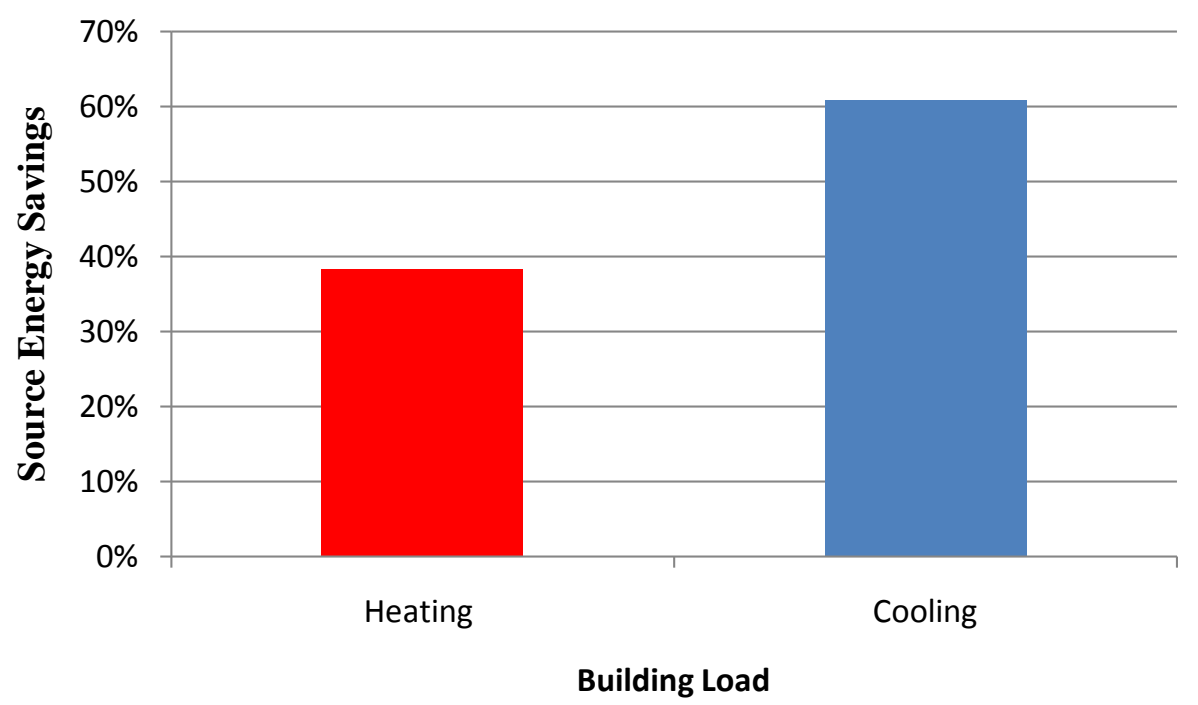

Figure 78. Simulated Energy Savings from Heating and Cooling Loads

\section{Diagnostics and Test Out}

When scheduling with subcontractors permitted, Blower Door tests were done at intervals to investigate the effectiveness of individual retrofit measures. The results are shown in Table 42in the order in which the tests were done. Conducting successive diagnostic Blower Door tests can yield valuable information and insight into the impact of individual measures and facilitate more accurate prediction of energy savings. For example, as seen in the table, the air sealing measures taken in the attic and crawlspace yielded infiltration reduction of approximately $22 \%$. The air exchange rate decreased by about $34 \%$. The difference in the reduction is due to the added building volume of the converted storage room and the conditioned closet. Since the air exchange rate has a greater decrease than the infiltration rate, it can be assumed that the additional volume has a tighter envelope than the original building volume. This is expected since the new additions were insulated with spray foam insulation in the wall cavities and ceiling planes

Table 42. Pre-retrofit and post-retrofit air infiltration diagnostics

\begin{tabular}{|c|c|c|}
\hline Retrofit Measure Tested & $\begin{array}{l}\text { Blower Door Test Result } \\
\left(\mathrm{CFM}_{50} / \mathrm{ACH}_{50}\right)\end{array}$ & Percent Reduction $^{35}$ \\
\hline Initial & $3,111 / 17.7^{*}$ & \\
\hline $\begin{array}{l}\text { Addition to the House + Attic } \\
\text { Sealing + Crawlspace Band } \\
\text { Sealed with Spray Foam }\end{array}$ & $2,415 / 11.4^{* *}$ & $22 \%$ \\
\hline
\end{tabular}

\footnotetext{
${ }^{35}$ Percent reduction is determined by evaluating the $\mathrm{cfm} 50$ reduction for each of the retrofit measures as a ratio of the total building infiltration.
} 


\begin{tabular}{l|l|l|}
$\begin{array}{l}\text { Exterior Walls Blown with } \\
\text { Cellulose + Attic Registers } \\
\text { Capped }\end{array}$ & $2,155 / 10.1^{* *}$ & $8 \%$ \\
\hline Final & $2,155 / 10.1^{* *}$ & $30 \%$ \\
\hline
\end{tabular}

$* \mathrm{ACH}_{50}$ includes an initial building volume of $10,540 \mathrm{ft}^{3}$

** $\mathrm{ACH}_{50}$ includes building envelope additions $\left(12,750 \mathrm{ft}^{3}\right)$.

The impact of relocating and replacing the ducts is shown in Table 43. Overall, there was a $40 \%$ reduction in the overall duct leakage to the outside of the building envelope.

Table 43. Pre--retrofit and post-retrofit duct leakage diagnostics - duct leakage to outside measured as air flow at $25 \mathrm{~Pa}\left(\mathrm{CFM}_{25}\right)$ and normalized as a percentage $\left(\mathrm{CFM}_{25} / \mathrm{conditioned} \mathrm{area}\left(\mathrm{ft}^{2}\right)\right)$

\begin{tabular}{|l|c|c|}
\hline & $\mathbf{C F M}_{25}$ & \% Leakage to Outside \\
\hline Pre-Retrofit & 266 & $20 \%{ }^{*}$ \\
\hline Post-Retrofit & 160 & $9 \% * *$ \\
\hline \% Reduction & $40 \%$ & $55 \% * *$ \\
\hline
\end{tabular}

* The pre-retrofit conditioned area is equal to $1,318 \mathrm{ft}^{2}$.

** The post-retrofit conditioned area is equal to $1,755 \mathrm{ft}^{2}$.

Overall the final HERS index improved from 160 to 91, which reflects the significant energy savings that are predicted for this retrofit. In FY12, it is planned to sub-meter whole-house energy consumption, along with the contribution of major loads such as the air conditioner with an e-Monitor device. Additionally, utility bills will continue to be collected for comparison with pre-retrofit utility bills.

\section{Eagle Cost and Scope of Work}

The total improvements for this home are about $\$ 20,885$. Table 44 provides a summary of the final scope of work.

Table 44. Eagle final scope of work and costs.

\begin{tabular}{|c|l|l|c|}
\hline Home Characteristics & \multicolumn{1}{|c|}{$\begin{array}{c}\text { Pre-Retrofit } \\
\text { Conditions }\end{array}$} & \multicolumn{1}{|c|}{ Retrofit Measures } & Final Costs \\
\hline \multirow{2}{*}{ Exterior Walls } & R-0 & $\begin{array}{l}\text { R-13 blown cellulose } \\
\text { (main); }\end{array}$ & $\begin{array}{c}\$ 2,750 \text { (drill- } \\
\text { and-fill)* }\end{array}$ \\
\cline { 3 - 4 } & $\begin{array}{l}\text { R-15 open-cell spray foam } \\
\text { (storage room and } \\
\text { conditioned closet) }\end{array}$ & $* *$ \\
\hline
\end{tabular}




\begin{tabular}{|c|c|c|c|}
\hline Home Characteristics & $\begin{array}{l}\text { Pre-Retrofit } \\
\text { Conditions }\end{array}$ & Retrofit Measures & Final Costs \\
\hline $\begin{array}{c}\text { Attic/ } \\
\text { Knee walls }\end{array}$ & $\begin{array}{l}\text { R-11 fiberglass (flat } \\
\text { ceiling) }\end{array}$ & $\begin{array}{l}\text { R-38 (flat ceiling of the } \\
\text { original living area) } \\
\text { R-18 (flat ceiling of the } \\
\text { converted storage room) } \\
\text { R-18 (sloped ceiling of the } \\
\text { conditioned closet)/ } \\
\text { R-15 (knee walls) }\end{array}$ & $\$ 1,855$ \\
\hline Foundation & $\begin{array}{l}\text { Limited vapor barrier } \\
\text { coverage }\end{array}$ & $\begin{array}{l}\text { Vapor barrier properly } \\
\text { applied }\end{array}$ & $\$ 650$ \\
\hline Foundation Walls & $\mathrm{R}-0$ & $\begin{array}{l}\text { R-18 closed-cell spray } \\
\text { foam on crawlspace band; }\end{array}$ & $\$ 1,930 * *$ \\
\hline Cooling & 2.5 ton, 9 SEER & 2 ton, 18 SEER & \multirow{2}{*}{$\$ 13,700 * * *$} \\
\hline Heating & 55 kBtuh 76AFUE & 9.5 HSPF; 95 AFUE & \\
\hline
\end{tabular}

* The costs to repair the interior drywall $(\$ 1,100)$ are included

** The contractor did not break down the specific costs for the different places where spray foam was applied. Therefore, the total costs of $\$ 1,930$ are shown.

*** A mechanical room was built in the crawlspace to allow for access to the HVAC system from the interior of the home. The costs of the mechanical room $(\sim \$ 5,500)$ are included in the total costs. The HVAC system costs are $\$ 8,200$. 


\section{Two Cities}

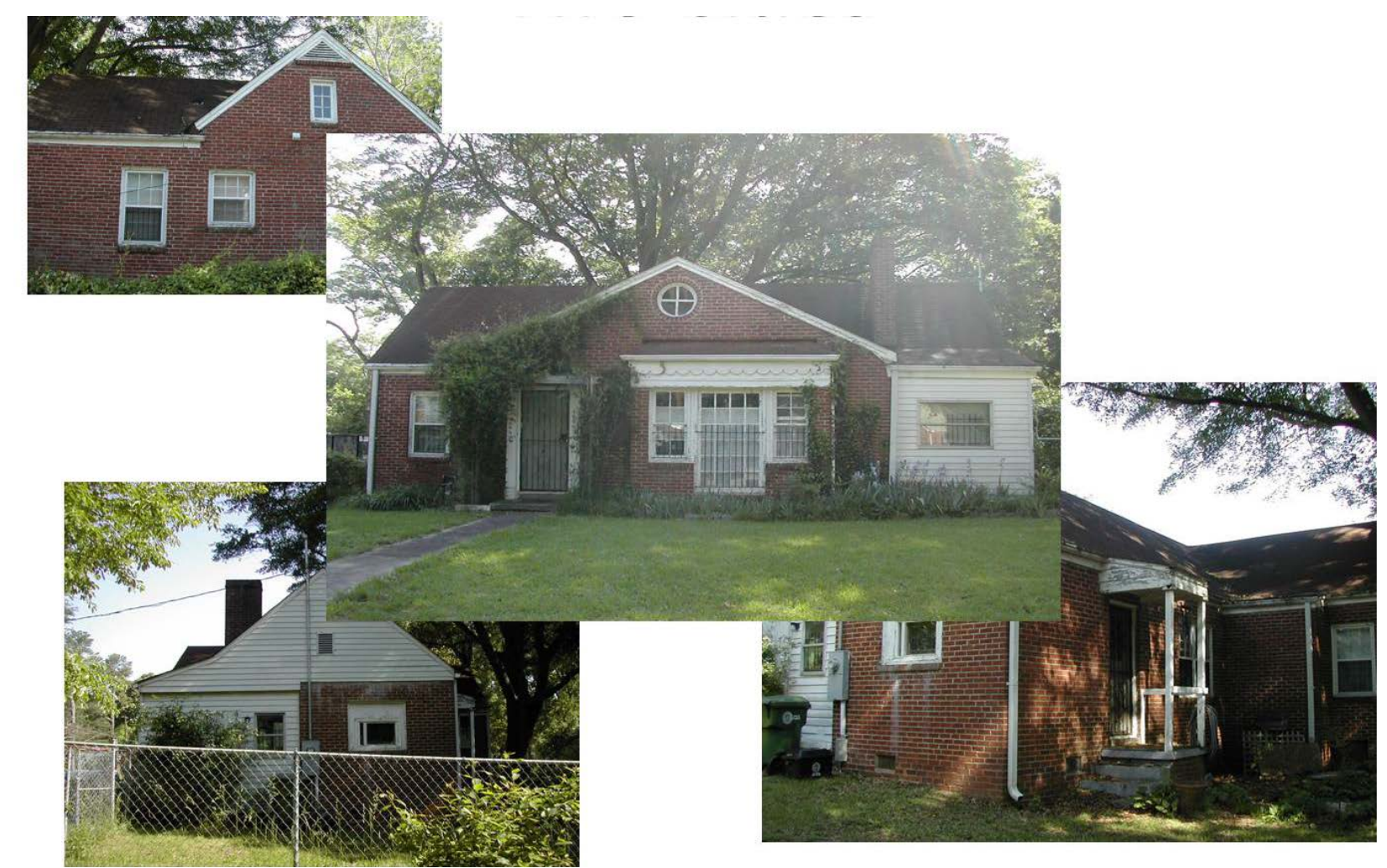

\section{Two Cities Home Profile}

Originally built in around 1945, Two Cities is a single story, single-family ranch style home with $1,110 \mathrm{ft}^{2}$ of living area. There are two bedrooms and one bathroom. Two Cities has a traditional vented attic and a vented crawlspace foundation. One adult lives in this home.

The homeowner purchased this unoccupied home in early 2009. Since then, the homeowner has diligently been renovating and implementing various energy-efficient upgrades, motivated in part by priorities regarding home resale value and energy conservation. Because of the amount of rebates available through the Sustainable Home Initiative in the New Economy (S.H.I.N.E) program, Georgia Power's Home Energy Improvement Program (HEIP), and various other federal and state tax incentives, the homeowner decided to start a deep retrofit project. The 2010 Federal Tax incentives for energy efficiency measures were coming to an end in December 2010, so the homeowner made sure to complete most of the work before then to qualify.

While this is an older home, the previous homeowner (prior to 2009) took the initiative to seize opportunities to improve the energy efficiency of the home. These energy efficient measures included installing a radiant barrier on the roofline and increasing the amount of blown insulation in the attic on the ceiling floor. 


\section{Two CITIES PRE-}

RETROFIT

CHARACTERISTICS

TYPE: One-story, single-family

home

SIZE: $1,110 \mathrm{ft}^{2}$

Occupancy: One adult

INITIAL ENVELOPE

PROFILE

WALL INSULATION: R-0

FOUNDATION BAND

INSULATION: None

ATTIC INSULATION: R-30

INITIAL MECHANICAL

\section{PROFILE}

Location: crawlspace

Cooling: 12 SEER (electric)

Heating: 91 AFUE

WATER HEATER: 0.59 EF

(electric)

INITIAL DIAGNOSTIC

RESULTS

HERS: 134

HESCORE: 7

AIR INFILTRATION:

3,800 $\mathrm{CFM}_{50}\left(24.9 \mathrm{ACH}_{50}\right)$

DUCT LEAKAGE TO OUTSIDE:

$45 \mathrm{CFM}_{25}$

DUCT INSULATION: R-6
Even though the home was purchased in 2009, the homeowner did not move into the home until after all retrofit work was completed in 2011. Therefore, it was not possible to collect utility bills for the home prior to the retrofit occurring.

\section{Two Cities Initial Characteristics}

\section{Envelope Profile}

An illustration of the building envelope is shown in Figure 79. The ceiling heights are $8 \mathrm{ft}$ throughout the home. The envelope is bounded by an uninsulated framed floor below the living area and an insulated ceiling plane. There was also no insulation on the walls or band joist of the vented crawlspace.

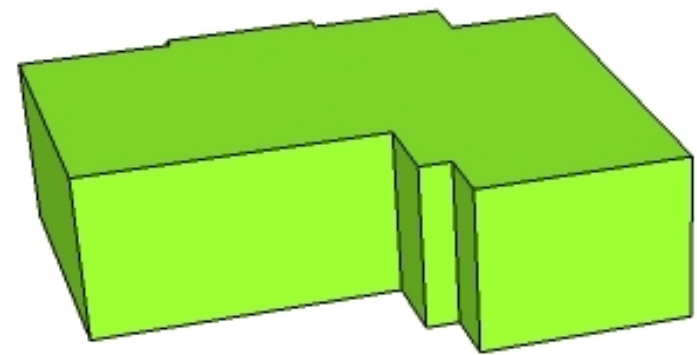

Figure 79. Illustration of the initial building envelope

In the attic, the ceiling had blown fiberglass with an average insulation coverage equivalent to approximately R-30. A photograph of the attic insulation is shown in Figure 80. Additionally, Two Cities also had a radiant barrier applied on the underside of the roof. This highly reflective material reduces the radiant heat transfer from the underside of the roof to the other surfaces in the attic; thereby, decreasing the temperature of the attic space in hot summer months.

While energy efficient measures such as increased attic insulation and radiant barrier installation were already implemented in Two Cities, attic bypasses were still evident in the attic. In particular, an open chase was found around the chimney and the water heater flue (Figure 81). These types of attic bypasses are not uncommon in existing homes. 


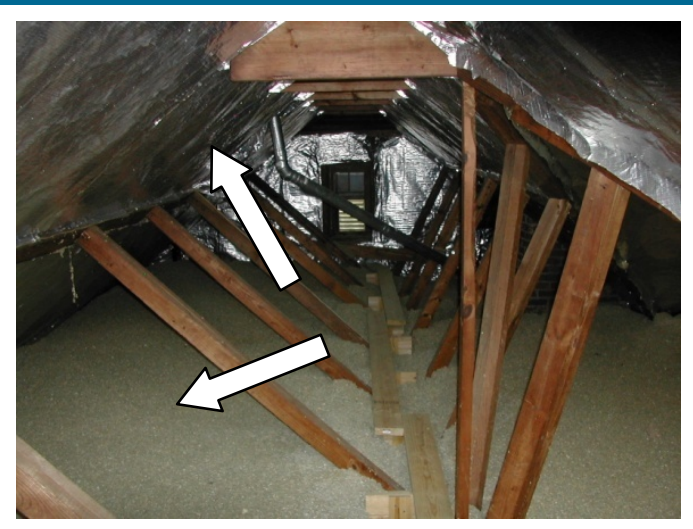

Figure 80. Photograph of the attic in Two Cities. The arrows in the figure are shown to highlight the radiant barrier on the roofline and the continuous layer of fiberglass insulation on the attic floor.

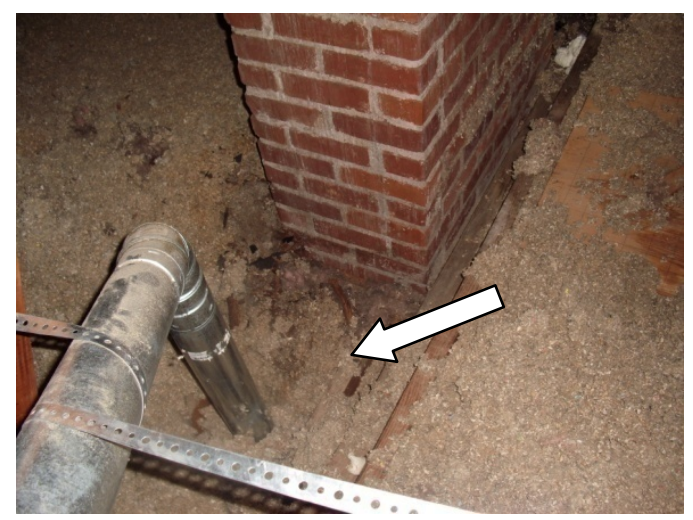

Figure 81. Open chase near the fireplace chimney and water heater flue.

Given the age of Two Cities, exterior wall insulation was not expected. To assist in the building assessment, thermal infrared imaging was done. Through the thermal scan and visual inspection of the house, insulation was not evident in exterior walls.

In addition to the attic bypasses shown in Figure 81, an exposed section of wall cavities were found behind a cabinet in the kitchen. An open plumbing access underneath the tub was also found in the crawlspace subfloor. Photographs of these infiltration pathways found in Two Cities that contribute to a "leaky home” are shown in Figure 82.

During the initial home energy assessment, a Blower Door test was conducted to evaluate the air infiltration. The total air leakage rate was 3,800 $\mathrm{CFM}_{50}$. With a conditioned volume of 9,140 $\mathrm{ft}^{3}$, the air exchange rate for Two Cities was approximately $24.9 \mathrm{ACH}_{50}$. The air exchange rate for this home is quite large, but is not unexpected given the infiltration pathways that exist, such as those shown in Figure 81 and Figure 82. Two Cities also has a whole-house fan installed, in addition to older, single pane windows with wood frames, which can also contribute to the excessive infiltration measured in the home. 

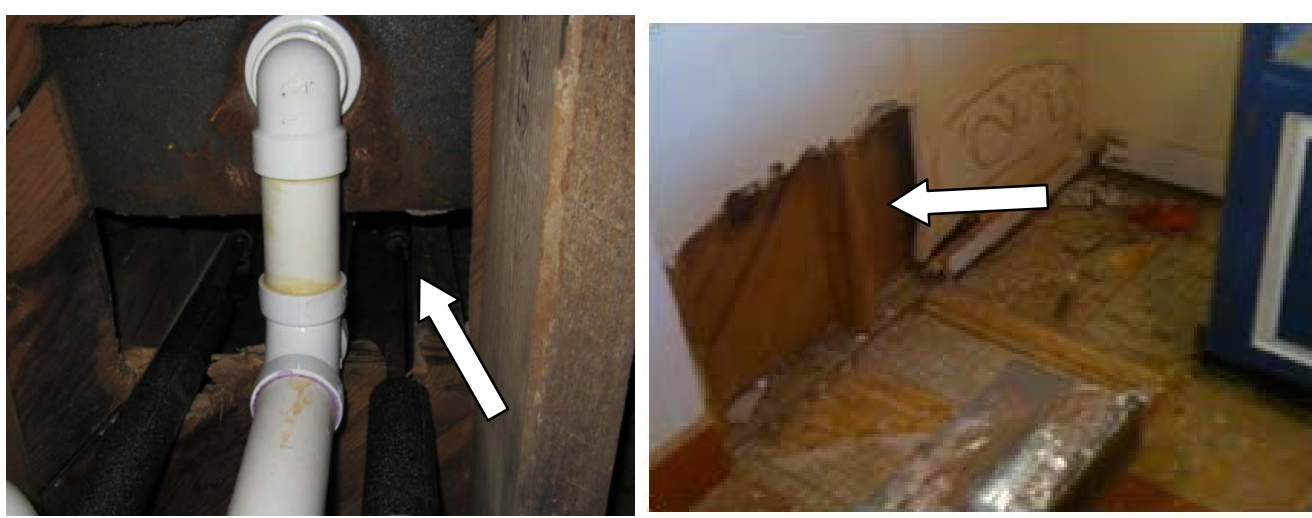

Figure 82. Infiltration pathways found in Two Cities. The photograph on the left shows an open plumbing access underneath the tub. The image on the right shows a hole in the kitchen wall behind a cabinet.

\section{HVAC}

Conditioned air was provided in Two Cities by a 2- ton capacity air conditioner, with an efficiency of 12 SEER. Heating for the home was provided by a natural gas furnace with a capacity of 45 kBtuh and a rating of 91 AFUE. The ducts were insulated with R-6 insulation and were located in the crawlspace with the furnace and air handler. Duct leakage tests were performed and yielded a duct leakage of $45 \mathrm{CFM}_{25}$ or $4 \%$ of the conditioned floor area.

\section{Lighting, Water Heating, Appliances}

The gas water heater was located in a closet behind a louvered door in the kitchen area. It had a storage capacity of 40 gallons and is rated at $0.59 \mathrm{EF}$. Three percent of the lighting was CFL bulbs. All appliances were standard efficiency. Both the range and oven were gas fueled.

\section{Health and Safety}

Combustion safety tests were applied on the atmospherically vented water heater in the living space. It passed all aspects of the combustion safety test: spillage, draft, and CO. No gas leaks were detected. 


\section{Retrofit Measures}

Using the prioritization protocol for this retrofit study, the following retrofit priorities were determined.

Table 45. Two Cities priority list

\begin{tabular}{|l|l|c|}
\hline \multicolumn{1}{|c|}{ Improvement } & \multicolumn{1}{c|}{ Existing condition } & Priority \\
\hline Air sealing & $\sim 1.25 \mathrm{ACH}_{\text {natural }}$ & $\mathrm{A}$ \\
\hline Improve ducts & $20 \%$ duct leakage & $\mathrm{B}$ \\
\hline $\begin{array}{l}\text { Insulate ATTIC (attic floor air sealing must } \\
\text { precede insulation work) }\end{array}$ & $\mathrm{R}-20$ & $\mathrm{C}$ \\
\hline Insulate WALLS & None & $\mathrm{C}$ \\
\hline Insulate FLOOR & None & $\mathrm{B}$ \\
\hline $\begin{array}{l}\text { Insulate BASEMENT/CRAWLSPACE } \\
\text { WALLS }\end{array}$ & None & $\mathrm{B}$ \\
\hline Radiant barrier & No radiant barrier & $\mathrm{D}$ \\
\hline Replace heating system & $92 \mathrm{AFUE}$ & $\mathrm{B}$ \\
\hline Replace cooling system & 12 SEER & $\mathrm{A}$ \\
\hline Replace water heater & .59 gas & $\mathrm{D}$ \\
\hline Insulate water heater and pipe & Gas & $\mathrm{C}$ \\
\hline Improve windows & Wood single pane & $\mathrm{C}$ \\
\hline Improve windows & Wood single pane with storm & $\mathrm{D}$ \\
\hline
\end{tabular}

Measures that received a priority of A or B from the prioritization protocol listed in Table 45were used as a basis for discussion with the homeowner on determining the final retrofit package. Retrofit measures included in the final package are described in the following text.

\section{Envelope}

Three inches of medium-density, open-cell foam was sprayed in the 2x8 joist cavities in the crawlspace subfloor for an approximate insulation value of R-15. After the installation was completed, the homeowner found areas of incomplete coverage and asked the installation contractors to return and address. Even though the HVAC system is located in the crawlspace, the homeowner decided not to pursue encapsulating the crawlspace because of existing water management problems due to the grading surrounding the home.

In addition to the open-cell foam applied in crawlspace, the insulation contractors agreed to apply three inches of the foam around the chimney chase to address the bypass shown in Figure 81. This air sealing measure is shown in Figure 83.

\footnotetext{
${ }^{36} \mathrm{ACH}_{\text {natural }}=\mathrm{ACH}_{50} / \mathrm{N}_{\text {corrected}}$, where $\mathrm{N}_{\text {corrected }}$ is the height-corrected LBL "N-factor" (http://www.bpi.org/Web\%20Download/BPI\%20Standards/Building\%20Analyst\%20Professional_2-28-05nNCnewCO.pdf)
} 


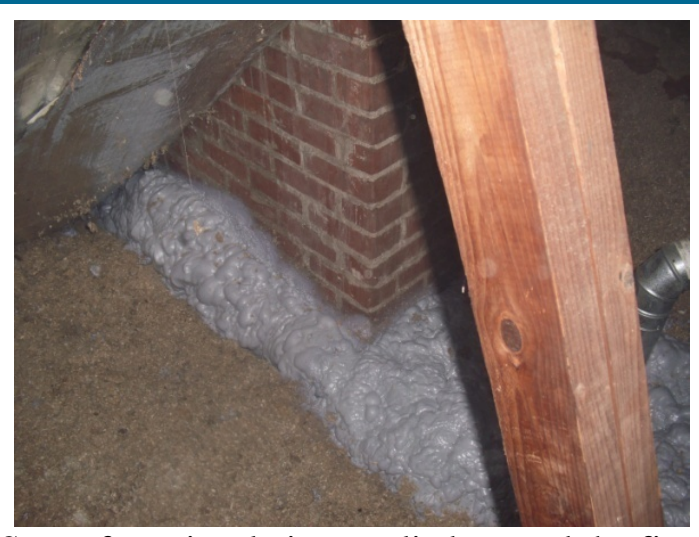

Figure 83. Spray foam insulation applied around the fireplace chase.

While insulating the walls was not listed as an A or B priority in the prioritization list (Table 45), the homeowner decided to include this measure as a part of the retrofit package. In addition to the reduced HVAC energy consumption that would be a product of wall cavity insulation, the homeowner noted the added "beyond-energy" benefit of increased thermal comfort afforded by this measure. Insulating the wall cavities would have the effect of reducing the mean radiant temperature (a common figure of merit for personal comfort), for a given temperature set point in the home. In other words, a room at an interior temperature of $73^{\circ} \mathrm{F}$ that has insulated exterior wall cavities would "feel" more comfortable to an occupant than a similar room at the same interior temperature but had no exterior wall cavity insulation.

Since the building had brick exterior in places, and the homeowner had plans to paint the interior of the home, it was more feasible and cost effective to blow cellulose insulation into the wall cavities from the inside of the home. Cellulose insulation was blown into a 3" diameter hole drilled near the top of each stud cavity (Figure 84). Special attention was given around the windows to make sure that no unusual blocking in the headers existed. By only drilling one hole near the top of the cavity, as shown in the figure, the insulation must fall to the bottom of the cavity and continue to build up to the top by gravity and forced air pressure.

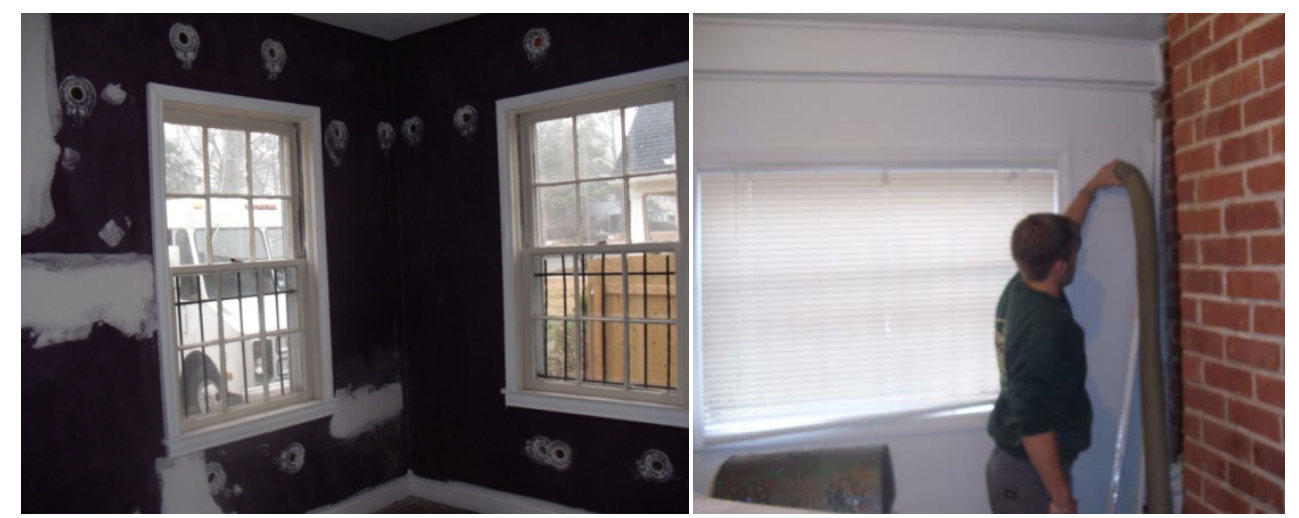

Figure 84. Drill and fill of cellulose insulation in the exterior wall cavities.

Because the walls are made of plaster, special attention was given to ensure that the walls did not crack or break due to the pressure in the cavity during the cellulose fill. A thermal scan of the 
exterior walls was performed after the work was complete to determine the final grade of the insulation (Figure 85). In general, the cellulose filled the cavities well, as seen in the figure.

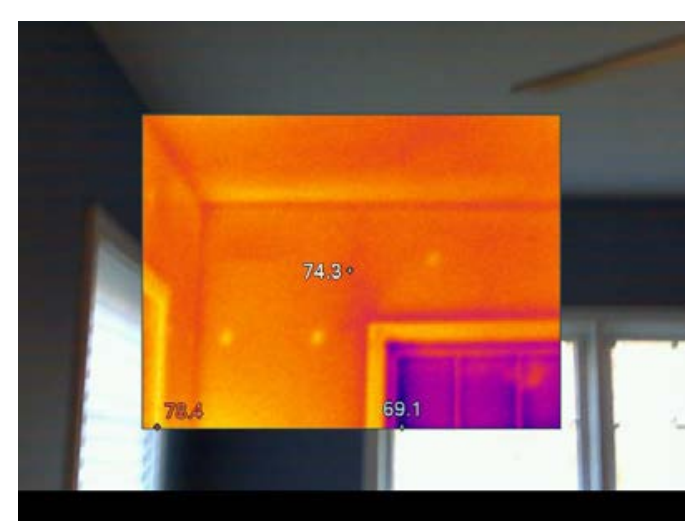

Figure 85. Thermal image of the exterior wall to show the grade of the insulation installation. The white dots in the figure are the Styrofoam plugs placed in each cavity after being filled.

Because of the significant air exchange rate initially measured in Two Cities, potential infiltration pathways in the home were aggressively sought. For example, the whole-house fan was removed and initially replaced with rigid foam insulation to cover the hole. However the homeowner decided to instead replace the whole-house fan with an energy recovery ventilator (ERV). ERVs are typically installed in "tight" homes where mechanical ventilation is needed to provide sufficient levels of indoor air quality. In these cases, an ERV can mitigate the energy penalty of additional fresh air that is brought into the building. Mechanical ventilation is recommended when natural air exchange rate is $0.35 \mathrm{ACH}$ or less. Based on the zone and number of stories of Two Cities, an LBL "N" factor of 20 can be used to convert the original air exchange rate at $50 \mathrm{~Pa}$ to a natural air exchange rate of $1.25 \mathrm{ACH}$. While it is not likely that the envelope improvements completed in this retrofit will bring the air exchange rate to 0.35 , the homeowner still decided to install and use an ERV because of the added indoor air quality it can afford.

Other envelope measures meant to reduce air infiltration included the following:

- adding one-part spray foam to top plates in the attic

- $\quad$ installing a damper in the chimney

- air sealing around baseboards with one-part spray foam and caulk

- replacing 2 single pane windows with double pane windows

- removing one single pane window

- $\quad$ repaired the hole in the kitchen wall behind cabinetry (Figure 82) (wall cavity was also filled with insulation). 

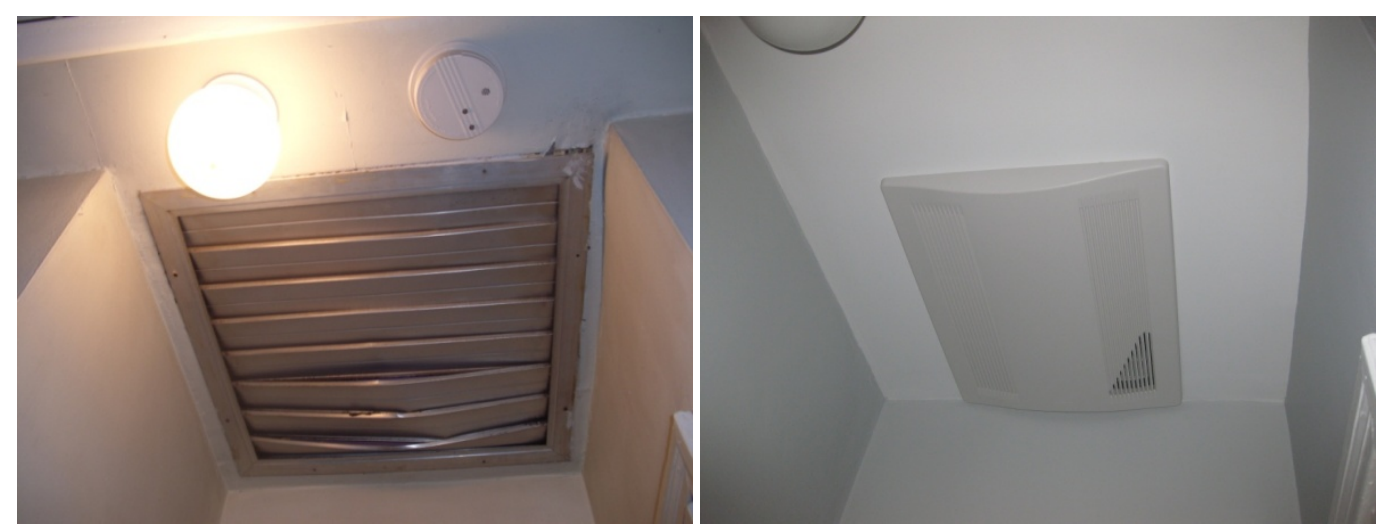

Figure 86. Spot energy recovery ventilator is shown in the image on the right. The initial whole-house fan is shown in the figure on the left.

\section{HVAC}

No improvements were made to the HVAC system with the exception of providing addition sealing around the boots. A programmable thermostat was installed.

\section{Lighting, Water Heating, Appliances}

All lighting in the house was replaced with CFLs, in addition to adding a sun tunnel in the kitchen. The refrigerator, washer, microwave, dishwasher, and ceiling fans were all replaced with ENERGY STAR products Figure 87. An insulation blanket and heat trap was added to the water heater.

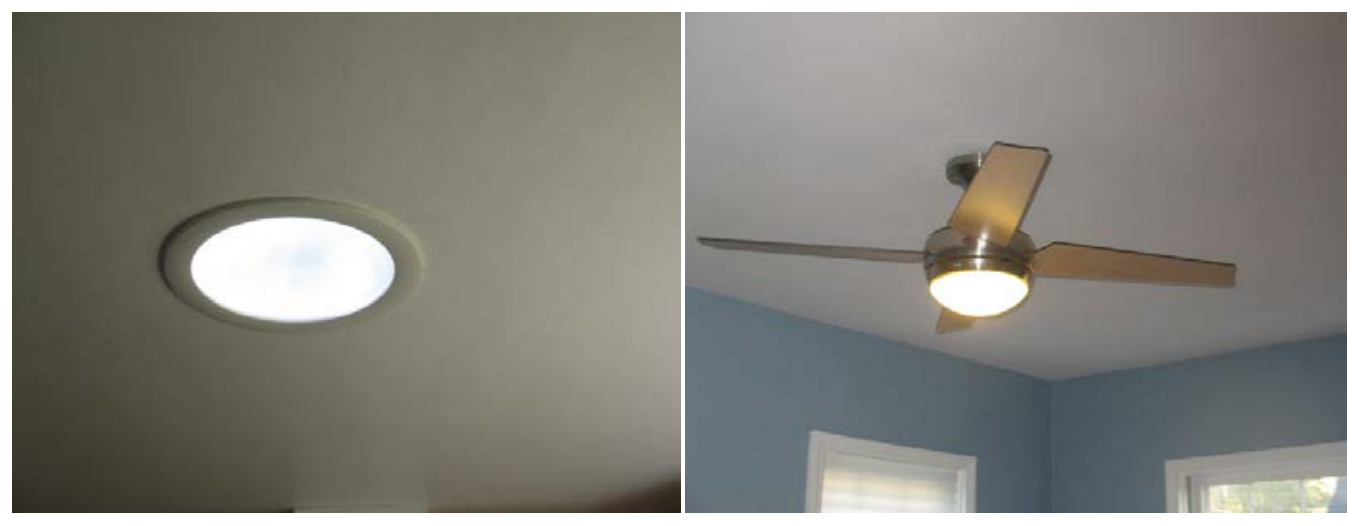

Figure 87. Sun tunnel (left) and ENERGY STAR ceiling fan (right)

\section{Health and Safety}

No combustion safety remediation was needed.

A spot ERV system was installed to provide improved indoor air quality. 


\section{Simulated Energy Savings}

Table 46 shows the simulated energy savings from the implemented retrofit measures.

Table 46. Two Cities retrofit package with simulated energy savings from EnergyGauge

\begin{tabular}{|l|l|r|l|l|}
\hline & $\begin{array}{l}\text { Predicted Site } \\
\text { Energy } \\
\text { (MMBtu) }\end{array}$ & $\begin{array}{l}\text { Predicted Source } \\
\text { Energy (MMBtu) }\end{array}$ & $\begin{array}{l}\text { Site Energy } \\
\text { Savings(\% per } \\
\text { measure) }\end{array}$ & $\begin{array}{l}\text { Source Energy } \\
\text { Savings (\% per } \\
\text { measure) }\end{array}$ \\
\hline $\begin{array}{l}\text { Two Cities } \\
\text { Simulated Energy } \\
\text { Use }\end{array}$ & 92 & 148 & & \\
\hline $\begin{array}{l}\text { + Lighting } \\
\text { Improvements }\end{array}$ & 91 & 144 & $29 \%$ & \\
\hline $\begin{array}{l}\text { ++ Envelope } \\
\text { Improvements }\end{array}$ & 65 & 112 & $22 \%$ \\
\hline $\begin{array}{l}++ \text { Appliance } \\
\text { Improvement }\end{array}$ & 61 & 103 & $4 \%$ & \\
\hline $\begin{array}{l}\text { Total Retrofit } \\
\text { Investment }\end{array}$ & & & $34 \%$ & \\
\hline
\end{tabular}

In total, there is an estimated 30\% reduction in source energy consumption. The predicted source energy savings from envelope improvements are $22 \%$, and are the largest of the improvements in this retrofit. This is due to the significant infiltration reduction measures taken in the retrofit along with the additional insulation added to the basement and the exterior wall cavities.

As can be seen in Figure 34, the energy savings for the primary building loads are significant. The heating source energy savings are almost 50\% in contrast to cooling savings of approximately $20 \%$. This is likely attributed to the fact that much of the cooling energy savings had been achieved prior to this deep retrofit through measures such as the continuous layer of insulation in the attic ceiling and the radiant barrier on the attic roofline.

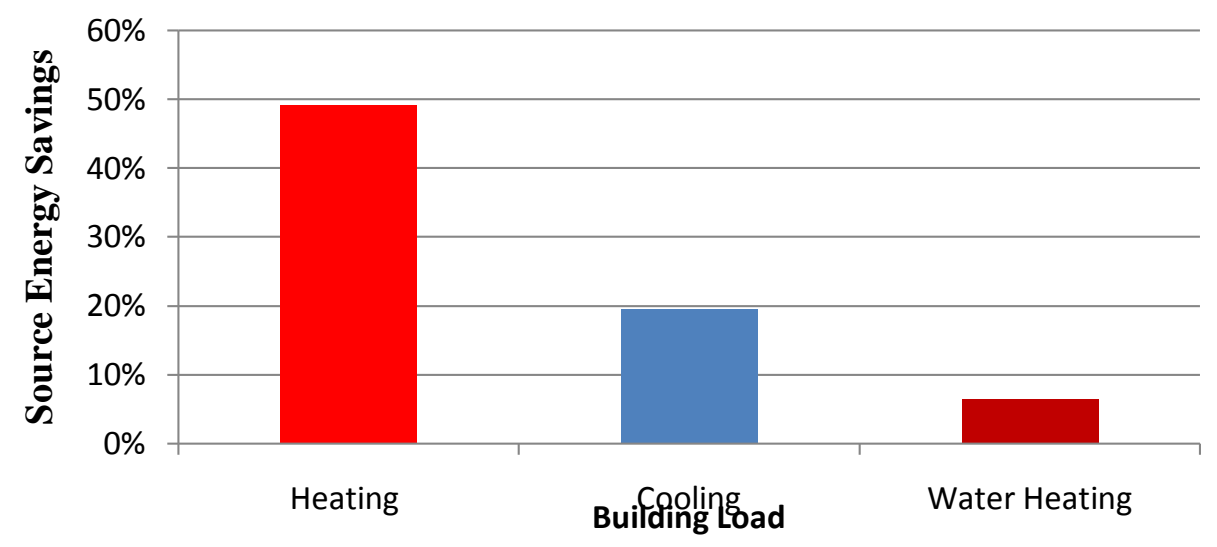

Figure 88. Simulated Energy Savings from Heating and Cooling Loads 


\section{Diagnostics and Test Out}

When scheduling with subcontractors permitted, Blower Door tests were done at intervals to investigate the effectiveness of individual retrofit measures. The results are shown in Table 47 in the order in which the tests were done. Conducting successive diagnostic Blower Door tests can yield valuable information and insight into the impact of individual measures and facilitate more accurate prediction of energy savings. For example, as seen in the table, a 32\% decrease in infiltration was achieved when the measures of repairing the hole in the kitchen wall (Figure 82), filling the exterior wall cavities with dense-packed insulation, and installing a chimney damper were completed. Before completing the retrofit, it is of note that the homeowner was able to reduce infiltration by 280 CFM $_{50}$ (7\%) with "do-it-yourself” air sealing measures such as identifying small holes around the perimeter of the baseboards and subsequently sealing with one-part spray foam. In total, a 58\% reduction in air infiltration was achieved in Two Cities.

It would have been desirable to more finely disaggregate the impact of the different retrofit measures on reducing air infiltration; however, logistical challenges with retrofit construction crews and construction practices did not permit. For example, the baseboards were left open after the cellulose was blown in the wall cavities. An infiltration test under these circumstances could have led to spurious conclusions because there would have been infiltration pathways that existed through the baseboards that would not exist in normal building operation.

Table 47. Pre-retrofit and post-retrofit air infiltration diagnostics

\begin{tabular}{|c|c|c|}
\hline Retrofit Measure Tested & $\begin{array}{l}\text { Blower Door Test Result } \\
\left(\mathrm{CFM}_{50} / \mathbf{A C H}_{50}\right)\end{array}$ & Percent Reduction \\
\hline Initial & $3,800 / 24.9 *$ & \\
\hline $\begin{array}{l}\text { Attic bypasses sealed + whole- } \\
\text { house fan replaced + foundation } \\
\text { subfloor sealed }\end{array}$ & $3,080 / 20.2$ & $19 \%$ \\
\hline $\begin{array}{l}\text { Wall insulation + wall repaired } \\
+ \text { chimney damper }\end{array}$ & $1,870 / 12.2$ & $32 \%$ \\
\hline $\begin{array}{l}\text { Additional "do-it-yourself” air } \\
\text { sealing measures }\end{array}$ & $1,590 / 10.4$ & $7 \%$ \\
\hline Final & $1,590 / 10.4$ & $58 \%$ \\
\hline
\end{tabular}

* $\mathrm{ACH}_{50}$ includes a building volume of $9,140 \mathrm{ft}^{3}$

Overall the final HERS index improved from 134 to 97, which reflects the significant energy savings that are predicted for this retrofit. In FY12, it is planned to sub-meter whole-house energy consumption, along with the contribution of major loads such as the air conditioner with an e-Monitor device. 


\section{Two Cities Costs and Scope of Work}

The total improvements for Two Cities are about $\$ 10,620$. Table 48 provides a summary of the final scope of work with associated costs.

Table 48. Two Cities final scope of work and costs.

\begin{tabular}{|c|c|c|c|}
\hline Home Characteristics & $\begin{array}{l}\text { Pre-Retrofit } \\
\text { Conditions }\end{array}$ & Retrofit Measures & Final Costs \\
\hline Exterior Walls & $\mathrm{R}-0$ & R-13 blown cellulose & $\$ 2,000$ \\
\hline Attic & $\begin{array}{l}\text { R-30 blown fiberglass } \\
\text { (flat ceiling) }\end{array}$ & N/A & N/A \\
\hline Foundation & $\mathrm{R}-0$ & $\begin{array}{l}\text { R-18 medium-density open- } \\
\text { cell }\end{array}$ & $\$ 1690$ \\
\hline HVAC & $\begin{array}{l}\text { No programmable } \\
\text { thermostat }\end{array}$ & $\begin{array}{l}\text { Programmable thermostat } \\
\text { added }\end{array}$ & $\$ 250$ \\
\hline Windows & Single-Pane Wood & $\begin{array}{l}\text { Double-pane fiberglass on } \\
\text { two windows. One single- } \\
\text { pane window removed. }\end{array}$ & $\$ 1,630$ \\
\hline Miscellaneous & & $\begin{array}{l}\text { Air sealing, e.g., foam gun, } \\
\text { caulk }\end{array}$ & $\begin{array}{l}\text { \$50 (caulk, gun } \\
\text { applicator, spray } \\
\text { foam) } \\
\$ 40 \text { (dryer vent cap) }\end{array}$ \\
\hline Lighting/ Appliances & Standard & $\begin{array}{l}\text { ENERGY STAR washer, } \\
\text { ceiling fans, dishwasher, } \\
\text { refrigerator, oven and stove; } \\
\text { high-efficient clothes dryer, } \\
\text { exterior lighting }\end{array}$ & $\begin{array}{l}\text { \$1,337 (washer) } \\
\$ 1200 \text { (refrigerator) } \\
\$ 600 \text { (dishwasher) } \\
\$ 200 \text { (ceiling fan) } \\
\text { \$150 (exterior } \\
\text { lighting) } \\
\text { \$675 (sun tunnel) }\end{array}$ \\
\hline Ventilation & None & ERV & $\$ 800$ \\
\hline
\end{tabular}




\section{Lessons Learned}

In this study, nine homes received comprehensive retrofits, and in all but one home, the projected source energy savings are about $30 \%$ or greater. During the planning and execution of these retrofits there were many lessons learned and challenges presented that can either advance the deployment of residential retrofits or hinder its market penetration. The following discussion will highlight key insight gained in this study.

\section{Expected Energy Savings}

In today's retrofit environment, there does not seem to be an exact definition of "energy savings”. Energy savings carries different meanings that include the following:

- Year to year dollar savings from utility bills,

o Post-retrofit utility bills are compared to pre-retrofit utility bills and the savings are determined from the difference between the two.

- Energy savings based on weather normalized utility bills

0 Pre- and post- retrofit utility bills are weather normalized and energy savings are determined. ASHRAE Guideline 14P specifies how to quantify energy savings of retrofitted buildings. A primary method identified in this guideline is to use linear regression to correlate energy use with weather data. However, this guideline is not widely used in the home energy retrofit community. In addition, there is no consistent weather normalization method for home energy modelers. Some modelers simply use heating degree days and cooling degree days to account for weather differences. However this assumes a constant home balance point, which is most likely not the case. Balance points will vary from home to home as well as within the same home but between pre- and post- retrofit conditions. In contrast, other modelers may use a change-point regression model.

- Asset-based simulated energy savings

o Energy savings are based on the home as an asset and based on a standard behavior. An energy modeling tool can be used to determine the pre-retrofit and post-retrofit energy consumption. Operational differences from homeowner behavior are not accounted for. The challenge arises from the fact that different software models predict vastly different energy consumption for the same home. Likewise, different modelers can also predict vastly different energy consumption, based on human error and perspective. For example, if there are unfaced R-13 batts located in a knee wall as in (North Carolina), the effective Rvalue that should be modeled is based on the person's perspective that enters the information into the energy simulation tool. There are many other subjective data that must be evaluated by energy simulation tools to determine overall energy consumption. Therefore, when the difference between software models is coupled with the variation between building modeler's perspective and opinion, there is a large opportunity for inaccurate and varied energy saving estimations. Furthermore, because the energy savings are based on the home as an asset and not as it is operated, there is no standard method to groundtruth the simulated energy consumption.

- Operation based simulated energy savings 
o Energy savings are based on the physical characteristics of the home in addition to the behavior of its occupants. This method allows for a "closed-loop" modeling approach where simulated energy savings can be compared to utility bills. With utility bills used as a feedback to the building modeler, the model can be calibrated to the actual building energy use. However there is no standard approach to this closed-loop method. For example, in order for utility bills to be compared with simulated energy consumption correctly, the utility bills and the simulated energy should be weather normalized before comparison. To date, there is no standard practice in the retrofit community. Additionally, once the utility bills and model have been normalized, there is also no standard calibration method. Model calibration varies widely and is largely based on the experience and expertise of the building modeler. This is a significant barrier because of the fact that most building modelers do not have extensive retrofit field experience and most retrofit practitioners do not have much building modeling experience.

- Attribution of energy savings

0 If a utility bill analysis is used to determine the energy savings of a comprehensive retrofit, it is difficult to attribute energy savings to specific measures. However, the importance of attribution in utility bill analysis is not as significant as in simulated energy savings. In the later case, homeowners may want to use the simulated energy savings of different retrofit measures as a decision tool. Consequently, if the energy savings are not well attributed, the ability to discriminate between retrofit measures is degraded. For example, in many homes in the Southeast, homeowners pursue attic encapsulation as a retrofit measure. The resulting insulation value of the spray foam on the roofline is relatively straightforward to determine. However, because encapsulating the attic has the effect of reinforcing the top pressure boundary of the home, the building infiltration will be reduced as well. The predicted amount of building infiltration reduction is not known, and cannot be accurately reflected in building energy simulation. Furthermore, as shown in homes in this study that had the attic encapsulated as a retrofit measure (i.e. New York, Yellow Jackets, Lakeview, and South Carolina), there was a variation in the "encapsulation" of the attic. Researchers in the study attempted to verify if the attic was "sealed" after encapsulation. Two out of the four homes seemed to suggest that infiltration pathways remained in attic even after encapsulation. Given this, the effectiveness of the retrofit measure will also be varied. The variation is further exacerbated by the fact that the amount of conditioning that each attic receives after being sealed is unique for each home. This is because the conditioning in the attic is a function of the leakiness of the ducts in the attic as well as the amount of bypasses in the attic to the conditioned space. Since each home is different, the conditioning will be different. As a result, the thermal environment (i.e. temperature and humidity) in the attic will be different, which has an overall effect on the HVAC performance and the thermal load on the living space of the home.

o Since each home is unique, there was significant variation in the improvement of different diagnostic metrics. For example, a HVAC contractor may be able to accurately estimate the final duct leakage after a new system is installed. However, if the ducts have a significant portion of in-wall registers and boots, the 
ability to adequately seal them will be varied, as in the case of Michigan in this report. For contractors to account for unknown difficulties, he/she will have to charge a premium for the service, which will adversely affect the costeffectiveness of the measure. While duct leakage may present a relatively manageable amount of variation between expected post- retrofit values, the expected improvement in retrofit measures such as air infiltration reduction is even more difficult to determine. In some homes with significant air infiltration, there may be one large hole in the building envelope that can easily be found and sealed. In other homes, there may be a series of smaller holes that are not easy to find and repair. For example, in Two Cities, there was a large hole behind one of the cabinets in the kitchen that likely attributed to the significant pre-retrofit air infiltration ( $\left.25 \mathrm{ACH}_{50}\right)$. Straightforward retrofit measures were able to address the infiltration to reduce it by almost $60 \%$. In contrast, South Carolina had an initial infiltration of $23 \mathrm{ACH}_{50}$. However, the retrofit contractor was only able to reduce the infiltration by $28 \%$. It is difficult for a homeowner to make an economic decision given this uncertainty.

\section{Building Characteristics}

In a home energy retrofit, it is difficult for a homeowner and contractor to fully understand the characteristics of unexposed places in the building envelope. A specific example is exterior walls. In North Carolina, South Carolina, Michigan, and Virginia, the retrofit contractor did not want to drill-and-fill insulation in the wall cavities, because he was not confident in the existence and coverage of sheathing and exterior vapor barriers particularly since the homes were built in the 1920s. Only in New York, where the siding was replaced, thereby permitting the exterior building properties to be verified, was the retrofit contractor willing to add insulation in the cavity. Once the siding was removed in New York, a vapor barrier was found on the interior of the wall cavity in one wall in the home. This was removed prior to insulation being blown in the cavity and a vapor barrier applied on the building exterior. The existence of the vapor barrier on the interior of the wall would not have been known if the siding had not been replaced, which could have led to moisture and durability issues in the future.

\section{Beyond-Energy Benefits of Retrofits}

Retrofits are currently marketed as a great way to save energy and thereby reduce overall costs. However, costs and energy savings are not the only reason, and in almost all cases not the primary reasons that the homeowners in this study pursued a retrofit. Home comfort and health and safety were reasons noted by homeowners as reasons for different measures. For example, in Yellow Jackets the atmospherically vented water heater was replaced with a direct-vent water heater. This was not only done due to expected water heating energy savings, but to enable the basement to be brought into the conditioned volume without fear of combustion safety issues from the natural gas fired water heater. Another example of "beyond-energy" benefits motivating a specific energy saving measure was wall cavity insulation. Insulating the wall cavities would have the effect of reducing the mean radiant temperature (a common figure of merit for personal comfort), for a given temperature set point in the home. In other words, a room at an interior temperature of $73^{\circ} \mathrm{F}$ that has insulated exterior wall cavities would "feel" more comfortable to an occupant than a similar room at the same interior temperature with no exterior wall cavity insulation. The homeowners in Eagle and Two Cities noted this as reasons for pursuing this measure. 


\section{Challenges in Specific Retrofit Measures}

- Ducts, registers, and boots in inaccessible areas

As discussed in Michigan, the contractor was not able to bring the duct leakage below $45 \%$ of the conditioned floor area, or $1140 \mathrm{CFM}_{25}$. A potential source of the remaining duct leakage was attributed to the supply and return registers that were mounted in the walls, in contrast to being mounted in the floor (Figure 26). When registers are located in walls, there is a potential for significant leakage in the cavity area that is not accessible from the crawlspace subfloor. In these cases, it is difficult to access the building cavity without damaging the interior wall finish.

- Wall cavity insulation in existing walls

o Insulating the wall cavity in older homes is a difficult measure to implement because of the possibility for negative unintended consequences with regard to moisture management in the wall cavities. With no insulation in the wall cavities, the walls are able to "breathe" in the event that moisture/water enters the cavity. If the wall cavity is retrofitted with insulation without proper consideration given regarding the ability for water to enter the cavity, there is a significant potential for water induced damage such as mold and wood rot. Because New York was built in the 1920s, there were many unknowns with regard to the makeup of the exterior wall system, such that understanding the ability for water to infiltrate the cavity was not evident. For example, it was not clear if there was exterior sheathing on the building. It was also not clear if there was a vapor retarder on the outside of the building envelope, and if there was a vapor retarder, it's overall integrity and effectiveness in mitigating bulk water transport into the wall cavity was not known. Because of these unknowns, insulating the wall cavities was initially not included in the retrofit package.

o When the drill-and-fill method is applied, it is not clear that the insulation completely fills the cavities. The contractors judge the cavity's state by stopping when the pressure builds up in the wall cavity, which can be felt in the hose used to fill the cavity. Because most of the New York had plank sheathing (Figure 11), the insulation could be seen filling the cavity as it was blown in. However, it was not clear if the density is consistent throughout the cavity.

- Encapsulated attics and crawlspaces

As discussed, there was a variation in the amount of attic isolation from the building exterior in the homes that had the attic encapsulated (i.e. the attics remained partially vented to the outside). This can be due to a soffit that was not adequately covered, or to other hidden leakage points. However, because infiltration paths remain, the expected hygrothermal attic environment and its impact (either negative or positive) are not clear.

- Need for less intrusive/disruptive retrofit approaches

Equipment replacement and repair are relatively straightforward retrofit measures. However, it is often cost prohibitive from both a dollar and time/lifestyle disruption perspective to pursue more aggressive approaches such as wall cavity insulation and attic encapsulation. 


\section{Logistical Challenges in the Overall Retrofit Process}

In some of the homes in this study, planned retrofit measures did not result in expected performance, particularly in the case of infiltration or duct leakage. Revisiting the home to identify more improvements is difficult given the competing constraints on the amount of time a building contractor can commit to returning to a home to conduct more investigation versus the amount of homeowner "annoyance" that can reasonably be tolerated. A particular "annoyance", and thereby a significant barrier to returning to the home is the time away from work that a homeowner has to use to be at the home during the building retrofit. New construction, renovations, and rehabilitations may experience the similar constraint of contractor time, but are not often subject to the requirement that the homeowner be on-site and thereby off-work. In three different homes, the services of a home energy consultant were offered to identify additional infiltration and/or duct leakage reduction pathways; however, the building owner declined this service to try to minimize the disruption to the tenant's life.

\section{$\underline{\text { Retrofit Costs }}$}

The total costs to retrofit a home can vary considerably, based on a number of factors that include:

- The pre-retrofit "state" of the home. If the home is unoccupied, the costs and lifestyle disruption are reduced with respect to when the home is occupied. Two Cities was the only home in this study that was unoccupied during the retrofit. Therefore, it was easier to take a more aggressive retrofit approach without regard for "working around" the homeowner's work schedule, in addition to existing furniture and other household items. There is a cost associated with working around homeowners that contractors have to consider and include in their quoted price. In addition, if there are health and safety issues such as lead abatement that must be addressed, the costs increase significantly.

- Homeowner sophistication. In one of the homes, the homeowner was an experienced building scientist with a Ph.D. in mechanical engineering. Because of her expertise and understanding, she was able to sub-contract all of the retrofit work, and not require the services of a "retrofit general contractor" to ensure the retrofit was completed from a whole-building perspective. By not requiring a "retrofit general contractor" her costs were significantly lower than all other retrofits.

- General variation in retrofit costs. There is a significant variation in the costs of retrofit measures. For example, in Lakeview ( $900 \mathrm{ft}^{2}$ of roof surface area) the cost to encapsulate the attic was about $\$ 2000$, in contrast to South Carolina $\left(6,300 \mathrm{ft}^{2}\right.$ roof surface area) with a cost of almost $\$ 15,000$. This can likely be attributed to factors such as different roof areas, different attic conditions, different contractors, different spray foam products, and different encapsulation practices.

This list of lessons learned is a preliminary list of items the researchers in this study feel are necessary to understand and address to advancing residential retrofits. Further insight will be shared in the follow-up report that will compare actual energy savings to predicted energy savings. 


\section{Summary}

In total, nine homes were retrofitted in the metropolitan Atlanta, GA region. Eight of the homes are predicted to achieve source energy savings of approximately $30 \%$ or greater based on simulated energy consumption. Retrofit measures included:

- HVAC replacement and upgrade (high efficiency systems such as a variable capacity heat pump and mini-split ductless heat pumps were installed)

- $\quad$ Duct sealing

- Air sealing

- Attic encapsulation

- Drill-and-fill insulation in wall cavities

- Crawlspace encapsulation

In addition to detailed reports on all retrofits, lessons learned and observations were included in this report. Key items include:

- Challenges with regard to how energy savings are defined

- Obstacles to cost-effectively determining the building characteristics and diagnostics of a home prior the beginning the retrofit

- Need to determine and articulate the "beyond-energy" benefits of retrofit measures

- Technical challenges to specific retrofit measures

- Logistical challenges to homeowners during the retrofit

- Retrofit costs (costs are both high and variable)

The energy consumption of these homes will be monitored through monthly utility bills and inhome data monitors from September 2011 through August 2012, and compared to predicted consumption. A follow-up report will summarize the predicted versus actual energy saving 
